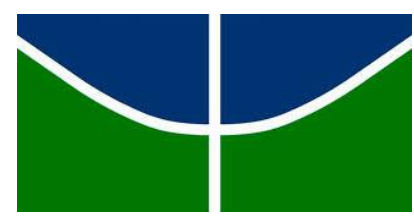

UNIVERSIDADE DE BRASÍLIA CENTRO DE DESENVOLVIMENTO SUSTENTÁVEL

TESE DE DOUTORADO

EMPREENDEDORISMO CRIATIVO E SUSTENTABILIDADE EM FAVELAS

PACIFICADAS NO RIO DE JANEIRO

ANDRÉA MELLO GOUTHIER DE VILHENA

Orientador: Prof. Marcel Bursztyn

BRASÍLIA

2016 
PROGRAMA DE PÓS-GRADUAÇÃO

CENTRO DE DESENVOLVIMENTO SUSTENTÁVEL

UNIVERSIDADE DE BRASÍLIA

\section{EMPREENDEDORISMO CRIATIVO E SUSTENTABILIDADE EM FAVELAS \\ PACIFICADAS NO RIO DE JANEIRO}

Andréa Mello Gouthier de Vilhena

Tese de Doutorado apresentada ao Programa de Pós-Graduação em Desenvolvimento Sustentável do Centro de Desenvolvimento Sustentável da Universidade de Brasília como requisito para obtenção do título de Doutora em Desenvolvimento Sustentável.

Orientador: Prof. Marcel Bursztyn

BRASÍLIA

2016 
Ficha catalográfica elaborada automaticamente,

com os dados fornecidos pelo(a) autor(a)

VV711e Vilhena, Andréa Mello Gouthier

Fmpreendedoriamo criativo e mutentabilidade em favelan pacificadan no Rio de Janeiro / Andrea Mello Gouthier Vilhena; orientador Marcel Bursztyn. Braailia, 2016.

$214 \mathrm{p}$.

Tese (Doutorado - Doutorado em Demenvolvimento Sustentavel) -- Univeraidade de Brasilia, 2016.

1. Suatentabilidade Urbana, 2. Bconomia Criativa. 3. Bconomia Solidsria. 4. Produçäo Arteanal. 5. Polftica de Pacificaçăo. I. Buraztyn, Marcel, orient. II. Título. 


\title{
EMPREENDEDORISMO CRIATIVO E SUSTENTABILIDADE EM FAVELAS PACIFICADAS NO RIO DE JANEIRO
}

\author{
Tese de Doutorado apresentada ao Programa de \\ Pós-Graduação em Desenvolvimento \\ Sustentável do Centro de Desenvolvimento \\ Sustentável da Universidade de Brasília como \\ requisito para obtenção do título de Doutora em \\ Desenvolvimento Sustentável. \\ Orientador: Prof. Marcel Bursztyn
}

Brasília, 24 de junho de 2016.

Banca Examinadora:

Prof. Dr. Marcel Bursztyn

Universidade de Brasília/ Centro de Desenvolvimento Sustentável - orientador

Prof. Dr. Elimar Pinheiro do Nascimento

Universidade de Brasília/ Centro de Desenvolvimento Sustentável - examinador interno

Dra. Cristiane Barreto

Universidade de Brasília/ Centro de Desenvolvimento Sustentável - examinador interno

$$
\text { Prof }^{\text {a }} \text { Dra. Annette Leibing }
$$

Université de Montreal/ Faculté des Sciences Infirmières - examinador externo

Prof. Dr. Neio Lucio de Oliveira Campos

Universidade de Brasília/Centro de Centro de Excelencia em Turismo - examinador externo 

Dedico essa tese ao saudoso Prof. Brasilmar Nunes (in memoriam), por encorajar e inspirar seus alunos. 


\section{AGRADECIMENTOS}

Voltar à academia, poder me dedicar a um tema de pesquisa era um velho sonho. Na rotina profissional como jornalista, nem sempre é possível uma análise mais apurada daquilo que nos toca de forma especial. Entretanto, foi essa mesma prática profissional que me colocou diante de uma realidade da qual eu nunca mais iria me distanciar. Ao trabalhar na Secretaria de Inclusão Social do Ministério da Ciência e Tecnologia, pude ver de perto a importância do apoio ao trabalho artesanal realizado por mulheres. Pude ver como o diálogo entre uma designer e uma artesã, com respeito à tradição do saber fazer e à herança cultural de quem faz, pode ser profícuo.

A trajetória como mulher, mãe e jornalista, me tornou mais aberta e sensível à realidade de tantas mulheres que, mesmo diante de um cotidiano muitas vezes árido, seguem, desatando nós e tecendo sonhos. A elas, a quem meu olhar se voltou cheio de admiração, meu agradecimento pela generosidade com que partilharam suas histórias e seu tempo, ao me receberem.

Agradeço ao meu orientador Marcel Bursztyn, pela condução firme no desenvolvimento dessa tese e pela confiança que depositou em mim. Suas sugestões e críticas foram fundamentais para tornar esse trabalho possível.

Às Prof ${ }^{\underline{a}}$ Teresa Caldeira e Karen Chapple por terem me recebido em Berkeley, no Institute of Urban and Regional Develpment, da Universidade da Califórnia. A experiência internacional em um centro interdisciplinar com a presença de pesquisadores de diversos países possibilitou-me ampliar a análise sobre questões relacionadas à vida nas cidades. Questões como violência, pobreza, justiça social, saúde e educação que nos ajudam a refletir sobre o conceito de sustentabilidade urbana.

A todos os professores do Centro de Desenvolvimento Sustentável da Universidade de Brasília que contribuíram para essa pesquisa. Em especial gostaria de expressar minha gratidão ao Prof. Elimar Santos, ao Prof. Fabiano Toni e à pesquisadora Cristiane Barreto.

Aos professores Brasilmar Nunes (in memoriam), Christiane Girard e Annette Leibing, pelos comentários e sugestões relevantes em diferentes momentos da pesquisa.

Às pesquisadores Joana Nunes, Rose Compans, Gül Köksal e Isabella Nunes com quem tive a oportunidade de dialogar durante a realização da tese.

A todos os meus colegas do doutorado, pelas trocas preciosas. À Maria Amélia, em especial, pela amizade e apoio.

Aos amigos Ana Fraga, Márcio Torres, Maria de Lourdes Cavalcanti, Ana Furniel, Julia Butterfield pelas contribuições e apoio, assim como a todos os outros amigos por fazerem parte da minha vida.

Ao casal Aline Pereira e Rolf Mortenson por terem ajudado a me sentir em casa quando fiz meu doutorado sanduíche nos Estados Unidos. 
Aos meus pais, Humberto e Eutímia, pela oportunidade que me deram de chegar até aqui e por me incentivar sempre a estudar. À minha avó materna, Jair, pelo exemplo de determinação. A Letícia e Lúcia, pelo carinho fraterno.

Aos meus filhos, Júlia, Pedro e Manuela, que só me trazem felicidade e renovam minha energia a cada dia.

Ao Saulo, meu marido e companheiro, pela leitura atenta e pelos questionamentos que proporcionaram contribuições importantes à tese e, ainda, pelo apoio dado à nossa família neste período em que precisei estar mais dedicada ao trabalho.

À CAPES, pela bolsa de estudo que me possibilitou uma dedicação integral à pesquisa.

À força divina, que me concedeu à graça da vida. 


\section{RESUMO}

Cidade de grandes contrastes em sua paisagem natural, o Rio de Janeiro também é caracterizado por grandes desigualdades sociais. Ao mesmo tempo em que se situava, em 2010, entre as dez cidades de maior dinamismo econômico do mundo, o Rio de Janeiro é a cidade brasileira que possui a maior população de moradores de favelas. O crescimento da violência nesses locais a partir da década de 1980, devido ao domínio territorial do tráfico de drogas e a uma sucessão de políticas de segurança fracassadas, levou a uma estigmatização territorial das favelas. Esse processo ocorreu concomitantemente e, em contraste, com a consolidação da redemocratização no Brasil. Estruturas políticas e policiais, ao invés de resguardarem o direito à vida e a outros direitos individuais, contribuíram para o fortalecimento de uma violência sistêmica que tomou conta da cidade e, de forma particular, das favelas. A atual política de pacificação, representada pelas UPPs, ao possibilitar a convivência de diferentes grupos sociais urbanos, pode contribuir para uma maior integração dos moradores do 'asfalto' com os da favela e vice-versa, favorecendo, assim, a sustentabilidade urbana. Nesse momento em que o Rio de Janeiro passa por inúmeras transformações, devido à realização dos grandes eventos esportivos, a cidade deve necessariamente integrar as favelas ao processo de revitalização urbana em curso. Ao trazer de volta a segurança pública aos moradores de favelas, as UPPs ampliam as possibilidades de desenvolvimento local, ao criarem um ambiente favorável para o florescimento de iniciativas empreendedoras. O presente trabalho buscou analisar a relação da pacificação das favelas cariocas com o desenvolvimento do empreendedorismo nessas comunidades, especialmente aqueles relacionados à produção artesanal realizada por mulheres. O impacto dessa política foi analisado por meio de pesquisas de campo em comunidades selecionadas, as favelas da Rocinha e Santa Marta, localizadas na zona sul da cidade. Juntamente com a análise de dados secundários que retratam a realidade social e econômica dessas comunidades, desenvolveu-se uma análise de percepções de atoreschave, identificados entre lideranças comunitárias, empreendedores individuais e associados, e gestores públicos das esferas federal, estadual e municipal. Os resultados dessas análises confirmaram a hipótese de pesquisa no caso da favela Santa Marta, onde o processo de pacificação encontra-se mais consolidado, indicando que a tragédia da segurança pública nas favelas, até o surgimento das UPPs, atuava como fator inibidor de iniciativas empreendedoras nesses territórios de grande potencial turístico e criativo. No caso da Rocinha, entretanto, por suas dimensões territorial e populacional e pelo fato de a política de pacificação ser mais recente, seus efeitos mostram-se menos evidentes, indicando, ainda assim, a presença de novos empreendimentos com a ampliação dos investimentos públicos e privados e a diminuição da presença ostensiva do tráfico.

Palavras-chave: Sustentabilidade Urbana; Economia Criativa; Economia Solidária; Produção Artesanal; Política de Pacificação. 


\section{ABSTRACT}

City of great contrasts in its natural surroundings, Rio de Janeiro is also characterized by a high social inequality. While in 2010 it was among the ten cities with the world's highest economic dynamism, Rio de Janeiro is the Brazilian city with the largest population living in slums. Violence has increased in these places from the 1980s, due to the territorial control of drug trafficking and a succession of failing security policies leading to a territorial stigmatization of slums. This process has occurred simultaneously and in contrast to the consolidation of democratization in Brazil. Political and police structures, rather than ensuring the right to life and other individual rights, ended up contributing to the strengthening of a systemic violence spread throughout the city and especially in the slums. The current pacification policy, represented by UPPs, has enabled the coexistence of different urban social groups contributing to greater integration of slums residents with the rest of the city, thus promoting urban sustainability. At this time, when Rio de Janeiro goes through a number of changes due the major sport events, it is necessary to integrate the favelas with the ongoing revitalization process of the city. Besides bringing back public security for its residents, the pacification policy is expected to promote a favorable environment for flourishing of entrepreneurial initiatives that can contribute to economic and social strengthening of these areas. This study aimed at analyzing the relationship of the pacification of Rio's favelas with the development of entrepreneurship in these communities, especially those related to artisanal production by women. The impact of this policy was analyzed through field research in selected communities, namely the slums of Rocinha and Santa Marta, located in the southern zone of the city. Along with the analysis of secondary data that portray social and economic aspects of these communities, we have developed a perception analysis from selected stakeholders identified among community leaders, individual and associated entrepreneurs, and public officials from federal, state and municipal levels. Our results confirmed the research hypothesis in the case of Santa Marta, where the pacification process is more consolidated, indicating that the tragedy of public security in the slums, until the emergence of UPPs, acted as an inhibiting factor of entrepreneurial initiatives in these areas of great touristic and creative potential. In the case of Rocinha, however, due to its territorial and population dimension and to the fact that the pacification process is more recent, its effects show up as less evident, indicating, nevertheless, a change in the entrepreneurship's profile, with the expansion of public and private investment and a reduction in the ostensive presence of drug dealers.

Keywords: Urban Sustainability; Creative Economy; Solidary Economy; Artisanal Production; Pacification Policy. 


\section{LISTA DE FIGURAS}

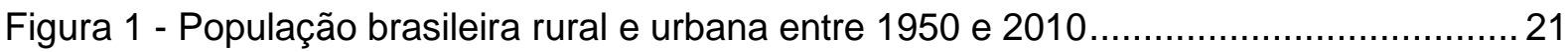

Figura 2 - Taxas de Homicídio por Área. Rio de Janeiro - 1980/2010 ................................. 43

Figura 3 - Vista aérea dos limites da UPP da favela Santa Marta. .....................................66

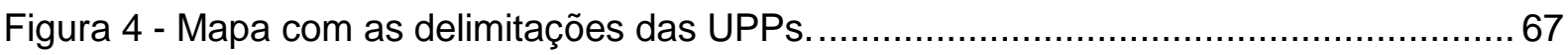

Figura 5 - Taxas de homicídio doloso no estado e na cidade do Rio de Janeiro (série

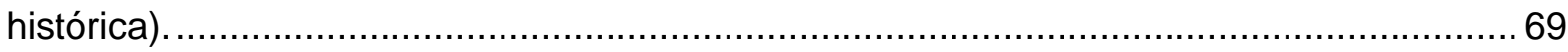

Figura 6 - Vítimas de homicídios por intervenção policial no município do Rio de Janeiro e

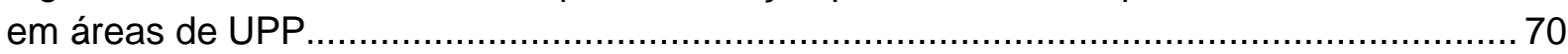

Figura 7 - Diretrizes da política UPP Social ................................................................. 83

Figura 8 - Princípios norteadores da economia criativa no Brasil ....................................... 92

Figura 9 - Taxa de homicídios por 100 mil habitantes em alguns estados brasileiros. ....... 107

Figura 10 - Proporção de mulheres e homens responsáveis por domicílios permanentes 108

Figura 11 - Taxa de desemprego entre homens e mulheres (em \%)................................ 109

Figura 12 - Rendimento homens/mulheres (em R\$). .................................................... 109

Figura 13 - - Percepção do impacto das UPPs sobre os empreendimentos em favelas..... 118

Figura 14 - Feira Rio Ecosol de artesanato - Praça do Largo do Machado ......................123

Figura 15 - Feira Rio Ecosol de artesanato - Praça do Largo do Machado ....................... 126

Figura 16 - Categoria social das sócias e sócios da economia solidária no Brasil- 2013. .. 130

Figura 17 - Favela Santa Marta com Cristo Redentor e o bairro do Humaitá ao fundo....... 141

Figura 18 - Bondinho do plano inclinado da favela Santa Marta ........................................ 142

Figura 19 - Carreta-escola do Senac - ao fundo a favela Santa Marta. .............................. 146

Figura 20 - Camisas em silk - loja Santa Marta Souvenirs de Andréia Miranda................. 149

Figura 21 - Turista holandês visitando a loja de Andréia Miranda na favela Santa Marta... 149

Figura 22 - Loja de souvenirs de Andréia Miranda ao lado do mosaico de Romero Brito... 150

Figura 23 - Andréia Miranda (à direita) em sua loja da favela Santa Marta e sua funcionária

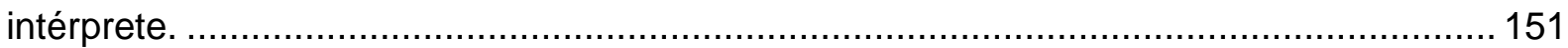

Figura 24 - A costureira Sonia Maria de Oliveira e favela Santa Marta. ............................. 153

Figura 25 - Local de trabalho do grupo Costurando Ideais.............................................. 155

Figura 26 - Marisete Gomes e Sônia Maria de Oliveira, do Costurando Ideais. ................. 155

Figura 27 - Painel pintado a mão pelo grupo Costurando Ideais ....................................... 156

Figura 28 - Almofadas produzidas pelo grupo Costurando Ideais .................................... 157

Figura 29 - Sônia, Marisete e Mariza do grupo Costurando Ideais da favela Santa Marta . 159

Figura 30 - Favela da Rocinha - vista da janela da Coopa-Roca...................................... 161

Figura 31 - Imagem da Rocinha, vista da pista de asfalto que passa em frente à favela. .. 161

Figura 32 - Valor do rendimento nominal médio das pessoas de 10 anos ou mais de idade

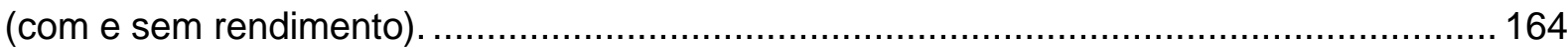

Figura 33 - Projetada pelo arquiteto Oscar Niemeyer, passarela liga o complexo esportivo à

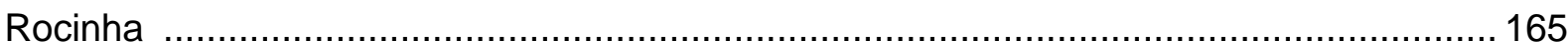

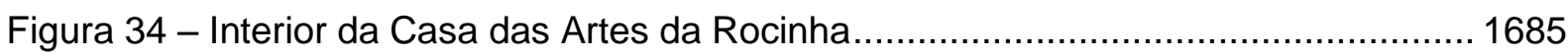

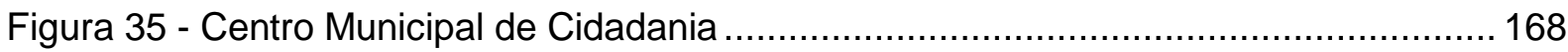

Figura 36 - Vestido de fuxico feito pelas costureiras da Coopa-Roca.............................. 173 
Figura 37 - Almofada bordada em linho

Figura 38 - Almofada bordada em linho.

Figura 39 - Maria Áurea, uma das diretoras da Coopa-Roca. ........................................ 175

Figura 40 - Bordados para aplique em roupa. Ao fundo, bolsa em crochê preta............... 176

Figura 41 - Bolsa em crochê. 


\section{LISTA DE TABELAS}

Tabela 1 - Crescimento da população total e de favela - Município do RJ - 1950/1991 ..... 26

Tabela 2 - Número de empregados com carteira de trabalho assinada no setor privado, por regiões metropolitanas (em 1.000 pessoas).

Tabela 3 - Dez maiores favelas da cidade - Município do Rio de Janeiro - 2010 


\section{LISTA DE QUADROS}

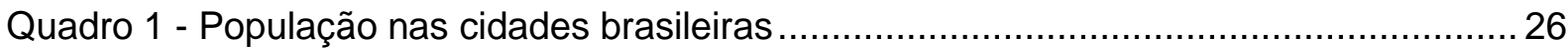

Quadro 2 - Taxas de Homicídio em 100 mil habitantes - Rio de Janeiro 1980/2010 ........... 43

Quadro 3 - Indicadores sociais e econômicos por bairros e comunidades selecionadas da cidade do Rio de Janeiro - 2000............................................................................... 105 


\section{LISTA DE SIGLAS}

ASPLANDE - Assessoria e Planejamento para o Desenvolvimento

CEPAL - Comissão Econômica para América Latina e Caribe

CHISAM - Coordenação de Habitação de Interesse Social da Área Metropolitana do Grande Rio

CIEPS - Centros Integrados de Educação Pública

CNFCP - Centro Nacional de Folclore e Cultura Popular

CUFA - Central Única das Favelas

DGTIT - Departamento Geral de Tecnologia da Informação e Telecomunicações

ENCE - Escola Nacional de Ciências Estatísticas

FBSP - Fórum Brasileiro de Segurança Pública

FIRJAN - Federação das Indústrias do Rio de Janeiro

FNS - Fundo Nacional de Saúde

GGIS - Gabinetes de Gestão Integrada de Segurança Pública

GPAE - Grupo de Policiamento em Áreas Especiais

IBGE - Instituto Brasileiro de Geografia e Estatística

IDHM - Índice de Desenvolvimento Humano Municipal

IETS - Instituto de Estudos do Trabalho e Sociedade

IPEA - Instituto de Pesquisa Econômica Aplicada

IPHAN - Instituto do Patrimônio Histórico e Artístico Nacional

ISP - Instituto de Segurança Pública

MEI - Microempreendedor Individual

MINC - Ministério da Cultura

MTE - Ministério do Trabalho e Emprego

NUPE - Núcleo de Estudos e Pesquisas em Educação

NUPESP - Núcleo de Pesquisas em Economia do Setor Público

OMS - Organização Mundial da Saúde

ONG - Organização Não Governamental

ONU - Organização das Nações Unidas

PCERJ - Polícia Civil do Estado do Rio de Janeiro

PM - Polícia Militar

PNAD - Pesquisa Nacional por Amostra de Domicílios

PNUD - Programa das Nações Unidas para o Desenvolvimento

PROMOART - Programa de Promoção do Artesanato de Tradição Cultural

PRONASCI - Programa Nacional de Segurança Pública com Cidadania 
PROTEJO - Projeto de Proteção dos Jovens em Território Vulnerável RIO ECOSOL - Circuito Carioca de Economia Solidária

SEASDH - Secretaria de Estado de Assistência Social e Direitos Humanos

SEBRAE - Serviço Brasileiro de Apoio às Micro e Pequenas Empresas

SEDES - Secretaria Especial de Desenvolvimento Econômico Solidário

SEDEIS- Secretaria Estadual de Desenvolvimento Econômico, Energia, Indústria e Serviços.

SENAES - Secretaria Nacional de Economia Solidária

SESCOOP - Serviço Nacional de Aprendizagem do Cooperativismo

UERJ - Universidade do Estado do Rio de Janeiro

UPP - Unidade de Polícia Pacificadora 


\section{AGRADECIMENTOS}

RESUMO

ABSTRACT

LISTA DE FIGURAS

LISTA DE TABELAS

LISTA DE QUADROS

LISTA DE SIGLAS

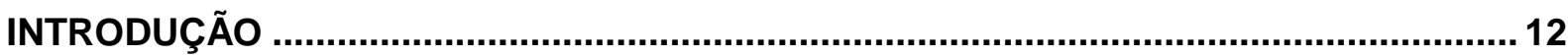

I. OBJETO:

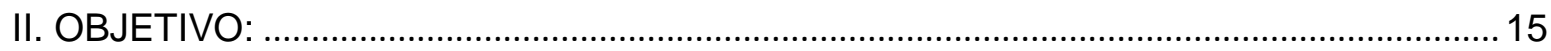

II. i. Objetivos específicos:.......................................................................... 15

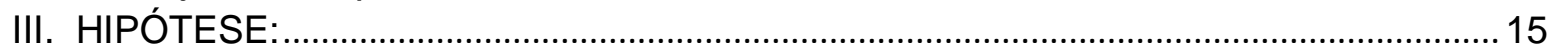

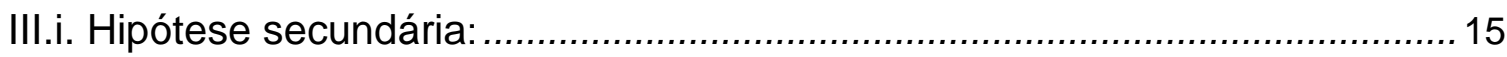

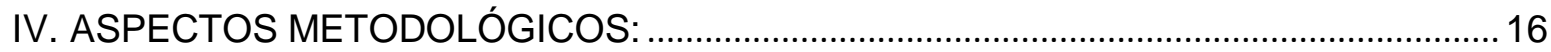

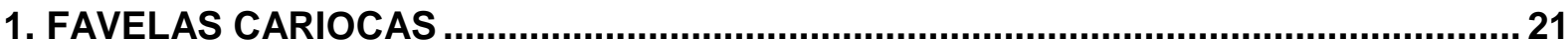

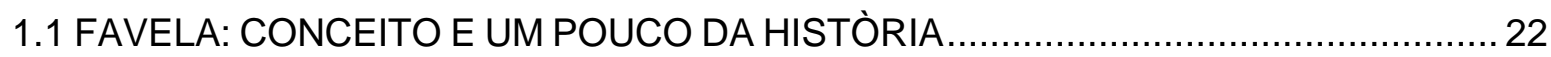

1.2 RIO DE JANEIRO: A MAIOR POPULAÇÃO DE FAVELAS DO BRASIL ......................26

1.2.1 A remoção das favelas e suas consequências ...........................................2

1.3 POBREZA URBANA: DA MARGINALIDADE À EXCLUSÃO SOCIAL ........................31

1.3.1 A VIOLÊNCIA COMO FATOR DE MARGINALIZAÇÃO ………………………….....

2. PACIFICAÇÃO DAS FAVELAS: IMPORTÂNCIA DA PAZ PARA A PROMOÇÃO DA

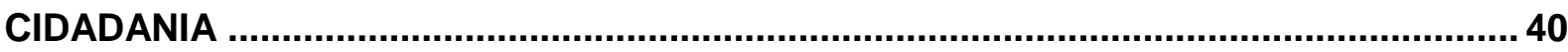

2.1 VIOLÊNCIA COMO PARTE DA DINÂMICA DA CIDADE ....................................... 42

2.2 ASCENSÃO DA VIOLÊNCIA NAS FAVELAS CARIOCAS ....................................47

2.3 VIOLÊNCIA, INJUSTIÇA E IMPUNIDADE NA CONTRAMÃO DA DEMOCRACIA ......50

2.4 POLÍTICAS DE SEGURANÇA DO RIO: ENTRE O RESPEITO AOS DIREITOS

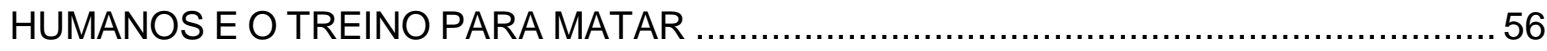

2.5 UNIDADES DE POLÍCIA PACIFICADORA (UPPS) ………....................................

2.6 PERCEPÇÃO DOS MORADORES EM RELAÇÃO ÀS UPPS ........................................73

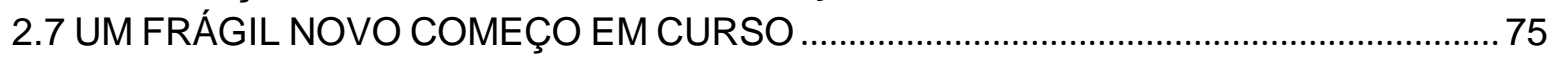

3. PACIFICAÇÃO DAS FAVELAS E A PROMOÇÃO DO DESENVOLVIMENTO LOCAL . 80

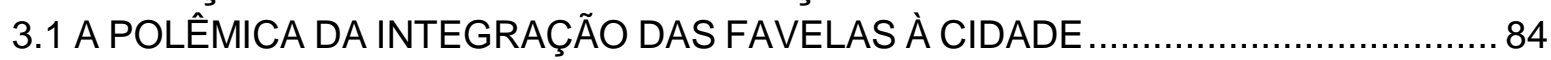

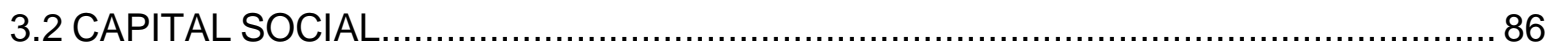

3.3 CRIATIVIDADE E SOLIDARIEDADE: FERRAMENTAS PARA O DESENVOLVIMENTO

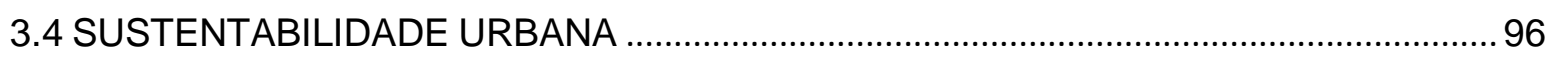

4. EMPREENDEDORISMO NAS FAVELAS CARIOCAS …............................................ 104

4.1 UMA OPORTUNIDADE PARA QUEM TEM BAIXA ESCOLARIDADE .........................104

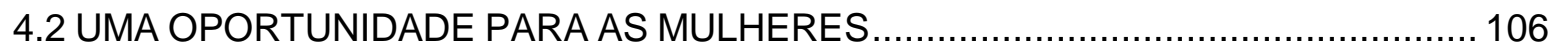


4.3 CRISE ECONÔMICA DESAFIA SUPERAÇÃO À POBREZA

4.4 A FORÇA ECONÔMICA DO EMPREENDEDORISMO NAS FAVELAS …................111

4.5 UPPS: IMPACTO NAS FAVELAS E NOS EMPREENDIMENTOS ………….............116

5. POLÍTICAS PÚBLICAS RELACIONADAS AO ARTESANATO …….............................. 122

5.1 O ARTESANATO NA CIDADE DO RIO DE JANEIRO ……............................... 122

5.2 O ARTESANATO E A ECONOMIA SOLIDÁRIA: PRODUZIR COM AS MÃOS A VIDA

5.3 O ARTESANATO E O MINC: O REPOSICIONAMENTO SIMBÓLICO NA BUSCA DE UM CIRCUITO MAIS CULT

5.4 O ARTESANATO E A SECRETARIA DE MICRO E PEQUENA EMPRESA: O QUE VALE É O PRODUTO COM IDENTIDADE CULTURAL

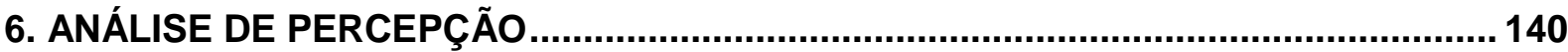

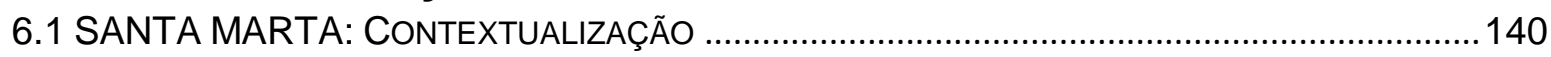

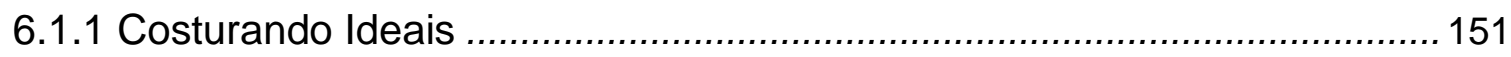

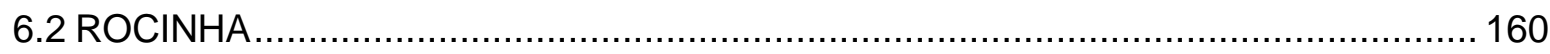

6.2.1 COOPA-ROCA: CONTEXTUALIZAÇÃO ………………………………………….....171

CONCLUSÃO

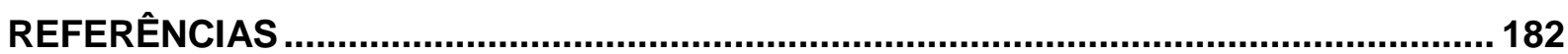

ANEXO 


\section{INTRODUÇÃO}

Após um longo período de decadência econômica, que teve início há pouco mais de meio século, com a transferência da capital federal para Brasília, a cidade do Rio de Janeiro passa por uma fase de revitalização. As mudanças são tão visíveis que estudo publicado pela Global Metro Monitor - publicação conjunta da London School of Economics e da Brookings Institution ${ }^{1}$ - insere a cidade no seleto rol das 10 mais dinâmicas do mundo. A comparação utiliza como parâmetro o dinamismo econômico, que por sua vez é baseado na evolução do emprego e da renda das 150 maiores metrópoles do mundo, medida em dois momentos: antes da crise econômica de 2008 que assolou o mundo (1993-2007) e depois (2008-2010) (URANI; GIAMBIAGI, 2011).

Entre os diversos fatores que contribuíram para que o Rio de Janeiro tenha caminhado na contramão da crise internacional, atraindo investimentos públicos e privados, destacamos o processo de pacificação das favelas e a consequente queda dos índices de violência. Um processo que se iniciou em 2008, com a instalação da primeira UPP no Morro Dona Marta, no bairro de Botafogo, e teve como "marco simbólico culminante" do esforço do poder público em prol da segurança a ocupação do Morro do Alemão, em 2010 (URANI; GIAMBIAGI, 2011).

No entanto, apesar do dinamismo de sua economia, a cidade ainda patina na busca de soluções para seus problemas sociais. Um deles é a pobreza urbana, cujo locus emblemático é representado pelas favelas. O Rio de Janeiro é a cidade que possui a maior população de moradores de aglomerados subnormais ${ }^{2}$ do país. Dos seus 6.323 .037 habitantes, 1.393.314 pessoas vivem em favelas. Esse número representa $22,03 \%$ da população carioca (IBGE, 2010). A cidade de São Paulo, embora tenha mais aglomerados subnormais do que o Rio (1.020 ao todo),tem uma população de moradores de favelas e loteamentos irregulares inferior (1.280.400 habitantes).

Primeira cidade a receber o título da Unesco de Patrimônio Mundial como Paisagem Cultural Urbana, a cidade ostenta em sua paisagem o maior aglomerado subnormal do Brasil, a Rocinha. Em 2010, a população dessa comunidade era de 69.161 moradores e

\footnotetext{
${ }^{1}$ The Path to Economic Recovery: a preliminary overview of 150 global metropolitan economics in the wake of the great recession.

${ }^{2}$ Em nossa pesquisa, optamos por usar o conceito de favela como análogo ao de aglomerados urbanos subnormais adotado pelo IBGE.
} 
ocupava uma área de 864.479,2 m² (CAVALLIERI; LOPES, 2006). Mas esse número não parece ser uma unanimidade. Segundo depoimento do presidente da União PróMelhoramentos dos Moradores da Rocinha (UPMMR) ao jornal O Globo, em dezembro de 2011, a população da favela estaria entre 180 e 220 mil habitantes. Já o site www.rocinha.com.br a estimou em 200 mil habitantes, em fevereiro de 2004.

Embora transformada em bairro, por meio do Decreto $\mathrm{n}^{\circ}$ 6.011, de 1986, regulamentado em 1993 pela Lei $n^{\circ}$ 1.995, a Rocinha continua sendo reconhecida como favela. Segundo a ONG "Rocinha.org" ${ }^{3}$, responsável pelo site oficial da favela, essa transformação foi de cunho "burocrático", pois o lugar continua apresentando "características físicas de favela".

Além de representar uma ocupação espacial do território muito peculiar, as favelas estampam outras características que as tornam diferentes do restante da cidade. Se observarmos os dados publicados pelo Instituto Municipal de Urbanismo Pereira Passos ${ }^{4}$ quanto ao Índice de Desenvolvimento Social $(\text { IDS })^{5}$, por bairro, a Rocinha $(0,458)$ apresenta um IDS muito abaixo dos bairros vizinhos (Lagoa $(0,854)$, Leblon $(0,809)$, Ipanema $(0,801)$, Gávea $(0,787)$, localizados na Zona Sul da cidade, onde se concentra o IDS mais alto do Rio.

O contraste social estampado nesses locais é evidenciado, também, por estudo realizado pela Fundação Getúlio Vargas $(F G V, 2011)^{6}$, que demonstra ser a Rocinha a região administrativa da cidade que tem a população com menor nível de escolaridade, entre todas do município do Rio de Janeiro.

Debruçada sobre o túnel Zuzu Angel, que liga dois bairros de classe média alta do Rio de Janeiro - Gávea e São Conrado -, a Rocinha cresceu a uma taxa bem maior do que a do restante da cidade. Esse crescimento demográfico e espacial desordenado vem chamando a atenção dos governos estaduais e municipais, que buscam aumentar sua presença no lugar por meio de diversas ações.

"Mesmo com todas as suas imperfeições, ao longo da história desta cidade, não resta dúvida de que o Estado nunca esteve tão presente nas favelas como nos dias atuais. Favela-Bairro, PAC, UPPs e UPP Social são alguns dos projetos financiados com verba pública que acontecem hoje no intuito de incorporar a favela ao restante da cidade" (MOREIRA, 2013).

\footnotetext{
${ }^{3}$ http://www.rocinha.org/rocinhanarede/view.asp?id=181

${ }^{4}$ CAVALLIERI, Fernando. LOPES, Gustavo Peres. Índice de Desenvolvimento Social - IDS: comparando as realidades microurbanas da cidade do Rio de Janeiro. Rio de Janeiro: Instituto Pereira Passos, 2008. n.. 20080401 (Coleção Estudos Cariocas).

${ }^{5}$ IDS - inspirado no IDH calculado pela ONU, tem como base os resultados do Censo Demográfico do IBGE. É utilizado para caracterizar situações típicas das cidades brasileiras.

6 "UPP e a economia da Rocinha e do Alemão: do choque de ordem ao progresso". Rio de Janeiro: FGV. 2011.
} 
Para deixar de ser uma cidade partida, como a cunhou Zuenir Ventura, em seu livro homônimo, e incorporar os benefícios desse momento positivo que está sendo chamado de "a hora da virada" (URANI; GIAMBIAGI, 2011), o Rio de Janeiro precisa enfrentar o desafio de promover a integração das favelas com o restante da cidade. Essa integração passa, necessariamente, pela diminuição da desigualdade social e da criminalidade e pela melhora da qualidade de vida, aspectos necessários se o Rio almeja investir na sustentabilidade urbana. Essas questões serão abordadas na primeira parte desta pesquisa.

No primeiro capítulo, será discutido o conceito de favela, com uma reflexão sobre o "lugar" que as favelas ocupam na vida social da cidade do Rio de Janeiro. No segundo capítulo, será abordada a mudança que está ocorrendo nesses locais, devido à atual política de pacificação. Em seguida, no capítulo 3 serão mostrados o caráter inovador dessa política e a relação da queda dos índices de violência com a promoção do desenvolvimento local.

Integrar a realidade das favelas à cidade é um processo que começou com a reconquista, pelo Estado, desses territórios anteriormente dominados pelo tráfico de drogas e pelas milícias. Mas ele [...] "não se esgota aí: se a intervenção da polícia e das Forças Armadas é condição necessária para que o processo possa ter êxito, ela está longe de ser suficiente" (URANI; GIAMBIAGI, 2011, p. 9). As apostas agora apontam para as UPPs Sociais, programa que vai articular iniciativas de governo, do setor privado e da sociedade civil, buscando consolidar o desenvolvimento socioeconômico dessas áreas (HENRIQUES; RAMOS, 2011, p. 245).

Esta pesquisa avaliou a relação da pacificação das favelas cariocas com 0 fortalecimento do empreendedorismo. Mais especificamente será estudado o empreendedorismo realizado por mulheres artesãs, assunto abordado no capítulo 4, dada a forte presença das mulheres à frente desse tipo de atividade. No capítulo 5 , foram abordadas as políticas públicas relacionadas à atividade artesanal.

Como objeto de estudo, foram pesquisados dois grupos de mulheres artesãs de duas favelas cariocas: o Coopa-Roca da Rocinha e o Costurando Ideais do Morro Santa Marta. A escolha do primeiro se deve ao fato de ser uma cooperativa de mulheres artesãs já consolidada, que existe há 30 anos. Já o segundo, por estar localizado no Morro Santa Marta, a primeira favela a ter o programa de pacificação implementado. Esses grupos artesanais serão tema do capítulo 6 .

A tese vai tratar do objeto escolhido sob a ótica da sustentabilidade, considerando que esta se fundamenta nas dimensões econômica, social e ambiental do desenvolvimento (Relatório Brundtland). No caso da atividade artesanal, a dimensão econômica se evidencia pela sua contribuição para o sustento das famílias; a social, pela melhoria das condições de 
vida; e, em termos ambientais, pelo fato de a atividade não usar intensivamente matériasprimas e energia, além de promover o reaproveitamento de materiais.

I OBJETO:

Esta pesquisa tem como objeto o estudo do empreendedorismo em áreas urbanas de grande vulnerabilidade social, especificamente a produção artesanal realizada por mulheres.

II. OBJETIVO:

Analisar a relação da pacificação das favelas cariocas com o desenvolvimento do empreendedorismo social nessas comunidades.

II.i. Objetivos específicos:

- Estudar a importância da atividade artesanal realizada nas favelas cariocas para o sustento das famílias das artesãs. Atividade que adquire condições de se expandir a partir da política de pacificação implementada nesses locais. Nossa análise terá como foco a produção artesanal da Rocinha e do Morro Dona Marta.

- Analisar a contribuição da atividade artesanal realizada por mulheres em favelas cariocas, a partir da implementação da política de pacificação, para a inclusão social das produtoras, assim como para a coesão social da comunidade.

III. HIPÓTESE:

A presença do Estado em favelas por meio de políticas públicas de segurança e de ações sociais cria condições favoráveis ao fortalecimento do empreendedorismo nessas áreas urbanas.

III.i. Hipótese secundária:

A produção artesanal realizada por grupos de mulheres nas favelas cariocas, incrementada a partir da pacificação, é uma alternativa econômica que contribui para promoção da sustentabilidade das famílias das artesãs. 


\section{ASPECTOS METODOLÓGICOS:}

A abordagem qualitativa de pesquisa se propõe ao estudo dos fatos sociais a partir da compreensão de sua inserção em seus respectivos contextos. "Nesta perspectiva, que se opõe à visão positivista de objetividade e de separação radical entre sujeito e objeto da pesquisa, é natural que os cientistas sociais se interessem por pesquisar aquilo que valorizam" (GOLDENBERG, 2001, p. 19).

Nesse sentido, Severino (2000) irá sublinhar que a escolha do tema da pesquisa, feita a partir de "uma avaliação da relevância e da significação dos problemas abordados para o próprio pesquisador, em vista da relação com o universo que o envolve", é um ato político. Assim, a neutralidade almejada pela visão positivista não existe.

Em função da natureza de nosso objeto de pesquisa, foi escolhido utilizar o que Goldenberg caracteriza por um modelo qualitativo de pesquisa. Os modelos e técnicas qualitativas foram legitimados pelas pesquisas multidisciplinares na área das ciências humanas empreendidas pela Escola de Chicago no início do século XX. Nesse período, destacam-se os estudos de aspectos da vida urbana tais como: "delinquência, criminalidade, desemprego e pobreza, minorias e relações raciais" (GOLDENBERG, 2001, p. 27).

A partir desse enquadramento metodológico, foi escolhida como estratégia de pesquisa fazer a análise do efeito da pacificação sobre o empreendedorismo com base na percepção dos empreendedores nas favelas.

A primeira fase de nossa pesquisa qualitativa, com finalidade exploratória, foi realizada em 2013. Nessa fase foram visitados alguns grupos de artesãs, como o das Mulheres Guerreiras (favela da Babilônia) e o que reúne predominantemente mulheres de terceira idade no Galpão das Artes (favela Chapéu Mangueira), ambos localizados no bairro do Leme; o grupo Toque de Mão (favela do Morro do Fallet) no bairro de Santa Teresa e o ateliê do grupo Divinas Axilas, cujos integrantes, em sua maioria, são da favela Santa Marta, e possuem um ateliê fora da favela, localizado no bairro de Botafogo.

Em relação aos procedimentos metodológicos, utilizamos, desde essa etapa da pesquisa, técnicas de entrevista e observação não participante. A entrevista é uma das mais importantes ferramentas de trabalho do jornalismo, na qual tivemos a oportunidade de nos aperfeiçoar ao longo de nossa trajetória profissional. Ela pode ser usada para levantamento de informações e opiniões sobre determinado assunto ou para se traçar o perfil de alguém delineando seu modo de vida (AMARAL, 1987). Para sua realização é importante que o entrevistador tenha conhecimento prévio do assunto a ser tratado, um roteiro que sirva como um fio condutor para guiar o entrevistador, sem, contudo, cercear a formulação de 
novas questões à medida que a entrevista for se desenvolvendo. Dessa forma, o entrevistador deve estar sempre atento para o surgimento de novos elementos que possam ampliar o horizonte da contextualização do objeto investigado, mostrando outros aspectos a ele relacionados que antes não haviam sido cogitados.

A realização das entrevistas exige, ainda, que o entrevistador tenha tato e empatia com o entrevistado de forma a lhe inspirar confiança para que ele possa fornecer seu depoimento. Ao abordar assuntos que as pessoas têm dificuldade para falar, como a violência do tráfico, o entrevistador deve procurar compreender essas limitações e buscar alternativas para recolher os depoimentos sem expor seus entrevistados a situações que representem qualquer tipo de ameaça. Uma dessas alternativas é oferecer a possibilidade das pessoas não serem identificadas, falando em off. Nessa pesquisa, alguns depoimentos foram colhidos em off, depois que percebemos a dificuldade de algumas pessoas em tratar o tema pacificação versus violência. Em alguns casos, para driblar essa dificuldade, tivemos que fazer mais de uma entrevista com as mesmas fontes, deixando o assunto da violência para ser tratado por último, depois que já tivéssemos conquistado um grau de confiança maior dos entrevistados.

Alguns depoimentos foram colhidos sem gravações ou anotações na frente do entrevistado em situações que não estavam planejadas. Nesses momentos, muitas vezes tivemos acesso a revelações que ajudaram a entender melhor a complexidade das relações sociais nessas comunidades. Um desses momentos aconteceu quando abrimos mão de descer a Rocinha em um transporte público no final de uma tarde de entrevistas e pedimos para acompanhar nossas entrevistadas numa caminhada que cruzou a favela, por dentro, de seu ponto mais alto até a sua parte mais baixa. Outras situações semelhantes foram vivenciadas quando não nos restringimos a permanecer nessas comunidades apenas para cumprir a agenda de entrevistas.

A interação com os entrevistados foi crescendo ao longo da pesquisa e alguns nos incluíram em suas redes sociais do Facebook. Isso nos permitiu continuar em contato com eles durante todo o tempo da realização da pesquisa. Por meio do aplicativo Messenger, pudemos completar informações, enviar fotos e esclarecer dúvidas que surgiram durante a avaliação das informações e redação do trabalho. Assim, buscamos nos manter atualizados sobre o que estava sendo estudado até a etapa final da pesquisa.

Em 2015, revisitamos o grupo Mulheres Guerreiras e conhecemos artesãs de outras comunidades. Nesse ano, realizamos entrevistas semiestruturadas com participantes dos grupos Costurando Ideais (Favela Santa Marta), Janela Carioca (Favela Santa Marta), Coopa-Roca (Rocinha), Devas (Favela Nova Holanda), Rede Repesol (Favela do Alemão), 
Arteiras (Favela da Casa Branca), Rede Cidade de Deus de Economia Solidária, Rede Repesol do Complexo do Alemão e grupo Corte e Arte (Favela do Cantagalo). Visitamos, também, a feira Rio-Ecosol.

Um dos primeiros procedimentos adotados para a escolha das fontes de informação foi entrar em contato com a Secretaria Especial de Desenvolvimento Econômico Solidário do município do Rio de Janeiro, Nessa secretaria, entrevistamos a diretora de Economia Solidária e Comércio Justo da Secretaria, Ana Asti, em dois momentos. A primeira entrevista com Asti, foi realizada no inicio de nossa pesquisa de campo e nos ajudou a mapear os grupos de mulheres artesãs nas comunidades pacificadas. A segunda entrevista foi realizada em uma etapa posterior do trabalho, quando focamos nossa análise para as políticas públicas voltadas ao artesanato.

Mesmo após a obtenção de alguns contatos telefônicos das artesãs, em muitos casos encontramos inicialmente dificuldade de nos comunicarmos com elas. A maioria das entrevistadas não possui telefone fixo, apenas celular e em muitos lugares nas favelas o sinal telefônico é fraco ou inexistente. Dessa forma, para chegarmos a muitas dessas pessoas lançamos mão de contatos pessoais na cidade, amigos antropólogos e urbanistas que já trabalharam com favelas. Procuramos mapear, também, lideranças representativas das comunidades, por meio de consultas a reportagens publicadas em jornais de grande circulação. Foi dessa maneira que chegamos, por exemplo, ao líder comunitário José Martins de Oliveira, na Rocinha. Com sua ajuda, conseguimos, finalmente, entrar em contato com as artesãs do Coopa-Roca, que naquele momento atravessava uma fase de mudança de gestão. Uma vez realizado o primeiro contato com as fontes de informação nas favelas, procuramos, sempre que possível, marcar as entrevistas em seus próprios ambientes de trabalho para captarmos melhor a relação que essas pessoas possuem com esses espaços e com as comunidades em que vivem.

Outra técnica de pesquisa qualitativa utilizada foi a observação não participante. Após o término das entrevistas previamente agendadas, procurávamos permanecer mais tempo nas comunidades observando o lugar e as pessoas e buscando fatos que pudessem contribuir para o nosso trabalho. Nessas oportunidades, por vezes, os entrevistados acabavam nos apresentando a outros atores que tinham relações diretas ou indiretas com o tema da pesquisa. Dessa forma, ampliava-se o acesso a outras fontes de informação e aprofundavase a contextualização de nosso tema. No entanto, nenhuma dessas revelações feitas de forma informal e descontraída foi publicada sem autorização posterior de nossos entrevistados. 
Durante a pesquisa, um exemplo de como a rede de contatos foi se ampliando aconteceu após a entrevista realizada com a empreendedora Andreia Miranda da favela Santa Marta. Nesse dia, depois de colhermos seu depoimento, ficamos um bom tempo em frente à sua loja, observando o entra e sai dos turistas no estabelecimento comercial. Em dado momento, Andreia nos apresentou o pessoal que trabalha com turismo na comunidade e que faz de sua loja um ponto de visitação.

Procuramos, também, nos manter abertos para vivenciarmos ao máximo, durante o trabalho de campo, situações sociais que apareciam para além das entrevistas agendadas. Foi assim que surgiu um convite para irmos ao aniversário de uma liderança da Rocinha, com churrasco e roda de samba em cima de uma laje. Na ocasião, tentávamos fazer contato com as artesãs do Coopa-Roca e fomos informadas que elas estariam no evento. O encontro acabou, também, nos propiciando conhecer outras pessoas como José Luiz Summer, dono da Casa das Artes da Rocinha. Em outras ocasiões, desvelaram-se, por acaso, laços de parentesco com o pessoal do tráfico e a partir dessas descobertas passamos a compreender melhor as dificuldades das pessoas em falar sobre a nova política de segurança pública. Mantivemos o sigilo dessas revelações para não expor nossos entrevistados.

Depois da análise das entrevistas, foram selecionados como objeto de estudo os grupos Costurando Ideais, da favela Santa Marta, e o grupo Coopa-Roca, da favela da Rocinha. A longa trajetória da cooperativa Coopa-Roca e o fato de o grupo Costurado Ideais estar localizado em uma favela, considerada modelo da nova política de pacificação, foram fatores determinantes para essa escolha. No primeiro caso, os 30 anos de Coopa-Roca nos permitiu comparar a desempenho da cooperativa antes e depois da implementação da política de pacificação e conferir se ela, de fato, beneficiou a atividade empreendedora. No caso do Costurando Ideais, pudemos conferir que tipos de benefícios a nova política, em uma comunidade onde ela está mais consolidada, trouxe para o ambiente dos negócios.

Nessa fase, revisitamos os locais de trabalho desses grupos e colhemos novos depoimentos das artesãs, buscando suas percepções sobre o significado da produção artesanal para as famílias, as oportunidades oferecidas, os desafios, os gargalos e o mercado. Procuramos, também, entender as percepções das artesãs sobre a realidade que vivem, especialmente sobre o impacto da nova política de segurança pública em seus empreendimentos.

A pesquisa qualitativa teve, ainda, como foco as políticas públicas voltadas ao apoio à atividade artesanal, com o intuito de investigar em que medida elas têm contribuído para o reconhecimento da sua importância e para o seu desenvolvimento em áreas de 
vulnerabilidade social. Para essa etapa do trabalho, foram entrevistados gestores em nível municipal e federal.

Além das idas a campo e da realização de entrevistas com atores sociais e gestores de políticas públicas, utilizamos dados secundários quantitativos para contextualizar as condições sociais e econômicas nas favelas do Rio de Janeiro, e outros que indicam a relevância do empreendedorismo nesses locais. Esses dados quantitativos nos ajudaram a traçar um fio condutor para as entrevistas e proporcionar uma compreensão mais aprofundada da realidade após ouvirmos a percepção dos atores entrevistados.

Realizamos, ainda, uma revisão bibliográfica sobre os conceitos mais relevantes para o desenvolvimento da pesquisa, tais como os de desenvolvimento, sustentabilidade urbana, favela, economia criativa e economia solidária. 


\section{FAVELAS CARIOCAS}

No final dos anos 1960, o crescimento urbano brasileiro já se destacava no cenário mundial, por ter as mais altas taxas da América Latina e, possivelmente, de todo o Terceiro Mundo (PERLMAN, 1977). Naquela década, mais precisamente no ano de 1963, esse crescimento foi tal que sua população urbana superou a rural. Assim ao longo da segunda metade do século XX, "o índice de urbanização salta de 30\% aproximadamente em 1950 para 80\%". (BURSZTYN, 2003, p. 44). Em 2010, a população urbana chega a 160.879 .708 pessoas, representando $84,35 \%$ do total do país (IBGE, 2010).

O crescimento abrupto da população urbana é explicado principalmente pelo grande aumento das migrações internas (BRITO, 2006). Movida pelas transformações provocadas pelo desenvolvimento da industrialização, que ocorreu no Brasil a partir dos anos 1950, a população deslocava-se em massa do campo para as cidades (Figura 1). Se, por um lado, as cidades atraíam a mão de obra rural, acenando com um leque mais amplo de possibilidades de trabalho e de melhoria das condições de vida, por outro, essa mão de obra sofria com a mecanização do campo, que substituía braços por maquinários.

[A] estrutura agrária [no Brasi]), onde aproximadamente $90 \%$ das terras pertenc[iam] aos proprietários médios e aos latifundiários, permitiu que as modificações na organização da produção agrícola, procurando-se um aumento da produtividade, fossem realizadas fundamentalmente com a introdução indiscriminada de técnicas [...] [que] levaram a uma liberação contínua de mão-de-obra. (DALL'ACQUA, 1976, p. 56).

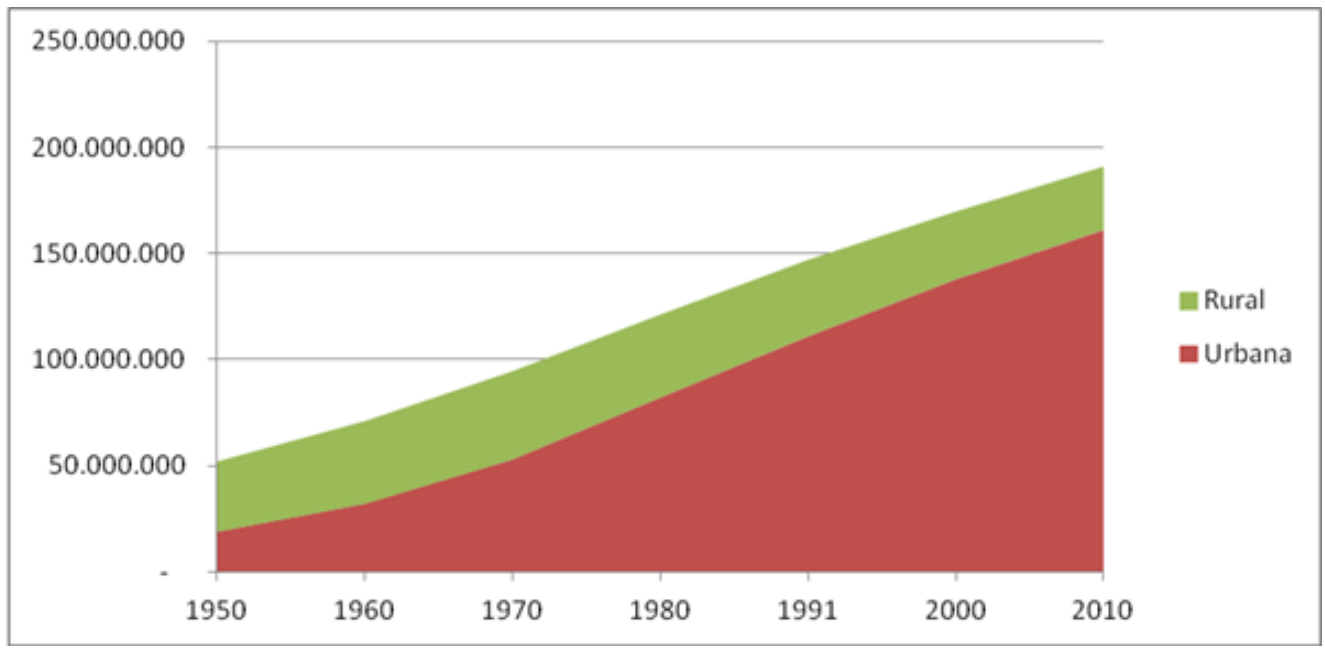

Figura 1 - População brasileira rural e urbana entre 1950 e 2010

Fonte: elaborado pela autora com base em IBGE 2010 
Outros fatores contribuíram, ainda, para o grande aumento populacional: as altas taxas de fecundidade, que começaram a cair apenas na segunda metade da década de 1960, e a rápida diminuição das taxas de mortalidade, que aconteceu em muitos países da América Latina após a Segunda Guerra (IBGE, 1999).

No final da década de 1960, quando Perlman iniciava sua trajetória de mais de 40 anos de pesquisa sobre as favelas do Rio de Janeiro, a cidade já se destacava como uma das cidades brasileiras de maior crescimento. Naquela década, o Grande Rio já contava com, aproximadamente, 300 favelas (PERLMAN, 1977), e a população da cidade era de cerca de três milhões de pessoas, sendo que um milhão delas viviam em favelas ou em outras formas irregulares de habitação (PERLMAN, 2003).

\subsection{FAVELA: CONCEITO E UM POUCO DA HISTÓRIA}

Em nossa pesquisa, optamos por usar o conceito de favela como análogo ao conceito de aglomerados urbanos subnormais, ${ }^{7}$ adotado pelo IBGE, pois no caso do Rio de Janeiro este conceito esteve historicamente relacionado às favelas (Rio de Janeiro, 2012, b). Dessa forma foi possível utilizar os dados secundários apresentados pelo instituto para caracterizar e contextualizar a realidade das favelas. De acordo com o IBGE, aglomerado subnormal é o

conjunto constituído de, no mínimo, 51 unidades habitacionais (barracos, casas...) carentes, em sua maioria, de serviços públicos essenciais, ocupando ou tendo ocupado, até período recente, terreno de propriedade alheia (pública ou particular) e estando dispostas, em geral, de forma desordenada e densa. (IBGE, 2010).

\footnotetext{
${ }^{7}$ A nomenclatura aglomerado subnormal do IBGE refere-se a diversos tipos de assentamentos irregulares existentes no país, tais como: favela, invasão, comunidade, baixada, palafita entre outros. No caso da cidade do Rio de Janeiro, os aglomerados subnormais se referem às favelas. Já o Instituto Municipal de Urbanismo Pereira Passos, da Prefeitura do Rio de Janeiro, define uma área como favela baseando-se nas seguintes características: "1) ocupação irregular da terra; 2) falta de títulos de propriedade formais, o que não significa que a ocupação seja ilegal; 3) tecido urbano disposto de forma irregular; 4) lotes pequenos e indefinidos; 5) vias estreitas; 6 ) infraestrutura de saneamento precária; 7) equipamentos sociais inexistentes ou insuficientes; 8) habitações precárias em desacordo com as normas; 9) inexistência de normas urbanísticas especiais. A rigor, as normas urbanísticas existentes deveriam ser aplicadas a todo o bairro, mas não é isso que ocorre. E, ao mesmo tempo, não existem normas urbanísticas especiais; 10) não inserção dos imóveis nos cadastros Imobiliários; 11) predominância de população de baixa renda" (RIO DE JANEIRO, 2012b). Fica claro que os conceitos se diferenciam principalmente no que se refere ao número de domicílios. Mas a partir de 2010, o IBGE, em um esforço para compatibilizar as definições, passou a adotar os nomes e limites de favela do IPP. Apesar de terem se resolvido inúmeras discordâncias em relação a esses limites, persistem ainda algumas diferenças, porém de forma muito mais reduzida. Se em 2000, 11\% desses limites eram incompatíveis em relação às diferentes definições dos dois institutos de pesquisa, hoje esse valor caiu para 3,5\%. Para efeito de nossa pesquisa, essa diferença não será levada em consideração (RIO DE JANEIRO, 2012b).
} 
Embora a categorização do termo favela tenha ocorrido apenas na segunda década do século $X X$, o fenômeno da favelização, no Brasil, é anterior a esse período. No final do século XIX, em 1897, a cidade do Rio de Janeiro já assistia ao início desse processo com a construção de barracos no Morro da Providência e, um ano mais tarde, no Morro de Santo Antônio, por soldados que voltavam da Guerra de Canudos (VALLADARES, 2005).

A origem do termo favela surge com a ocupação do Morro da Providência por esses antigos combatentes. Foram eles os primeiros a chamar esse morro carioca de Morro da Favella, por identificarem no local a existência de uma planta de mesmo nome, que existia no morro baiano da Favella, em pleno sertão baiano. O lugar fora palco da batalha final da Guerra de Canudos.

Embora o Morro da Providência tenha obtido maior destaque na história das favelas cariocas, a ocupação de outros morros na cidade, como Quinta do Caju, Mangueira e Serra Morena, já havia começado antes. Valladares (2005) pontua que a ocupação dessas áreas iniciou-se em 1881 e possivelmente foi autorizada, pois os primeiros moradores eram imigrantes estrangeiros _ portugueses, espanhóis e italianos,

Naquela época, o locus da pobreza na cidade ainda era representado pelos cortiços, considerados antros de vagabundagem, de crime e de epidemias. A destruição desses locais, motivada por uma preocupação higienista, teve início no final do século XIX, com o governo municipal de Barata Ribeiro e continuou com Pereira Passos, em sua grande reforma urbana realizada no início do século seguinte. No entender de alguns autores (ROCHA, 1986; CARVALHO, 1987; BENCHIMOL, 1990 apud VALLADARES, 2005), a desocupação dos cortiços teve como consequência a ocupação ilegal dos morros cariocas, no início do século XX.

Pouco a pouco, o significado do termo favela foi ampliado, passando a designar não mais apenas o Morro da Providência, mas "qualquer conjunto de barracos aglomerados sem traçado de ruas nem acesso aos serviços públicos, sobre terrenos públicos ou privados invadidos" (VALLADARES, 2005, p. 26). Foi no início do século XX que as favelas ocuparam as encostas dos morros cariocas, substituindo os cortiços como locus da pobreza.

Ao se propor a fazer uma "sociologia da sociologia das favelas", Valladares (2005, p. 23) vai além do resgate histórico da origem da palavra favela. Ela apresenta a evolução do pensamento intelectual no Brasil sobre esse fenômeno social urbano.

$\mathrm{Na}$ origem de suas representações sociais, a autora aponta como pedra fundamental, ou "mito de origem", a obra Os sertões, de Euclides da Cunha, na qual o autor faz a 
cobertura sobre a Guerra de Canudos $^{8}$ para o jornal O Estado de S. Paulo. Nas descrições realizadas pelos intelectuais do início do século $\mathrm{XX}$, as favelas são descritas como um mundo diferente do restante da cidade. Um mundo onde impera o caos, em oposição à ordem urbana e social. Essa oposição favela versus cidade tem como analogia, na obra de Euclides da Cunha, a oposição sertão versus litoral. De acordo com essa analogia, a vida na favela, tal como a no sertão, estava associada ao atraso e à miséria e a da cidade, assim como a do litoral, estava associada à modernidade.

Valladares mostra que a partir dessa representação social das favelas, presente nas primeiras descrições realizadas por jornalistas, médicos e engenheiros nas primeiras décadas do século $X X$, as favelas passam a ser tratadas como um problema social e urbanístico, uma "patologia social a ser combatida" (VALLADARES, 2005, p. 41).

Durante o governo populista de Getúlio Vargas, as favelas assumem uma nova representação. Reconhece-se a "existência das favelas e a necessidade de melhorar as condições de vida dos favelados, contrariando a solução única de sua destruição anteriormente proposta" (VALLADARES, 2005, p. 52). Ao invés de um problema a ser banido, a favela passa a ser vista como um problema a ser administrado e controlado, por meio de políticas públicas concretas.

Em 1948, três anos após a última fase do governo de Getúlio Vargas, foi realizado o primeiro recenseamento das favelas do Rio de Janeiro, na época, ainda Distrito Federal. Publicado em 1949, o documento contém interpretações preconceituosas a respeito da situação social das pessoas, chegando a justificar a predominância de pretos e pardos nas favelas por serem "hereditariamente atrasados, desprovidos de ambição e mal ajustados às exigências sociais modernas" (ZALUAR; ALVITO, 2006, p. 13).

Com o fim da política populista do "pai dos pobres", como era conhecido Getúlio Vargas, o documento serviu para "justificar o retorno de uma política prioritariamente de erradicação para as favelas" (VALLADARES, 2005, p. 66). Essa política contou com o reforço de uma forte campanha nos jornais da época, liderada pelo jornalista Carlos Lacerda, que sublinhava a favela como um problema a ser resolvido, em uma série de artigos intitulada Batalha do Rio de Janeiro. Nesses artigos, as favelas eram descritas como o lugar da desordem, da sujeira, da malandragem e da violência (ZALUAR; ALVITO, 2006).

No início dos anos 1950, as favelas ganham novas representações sociais, passando a ser valorizadas como comunidade (ZALUAR; ALVITO, 2006; VALLADARES, 2005). Nesse

\footnotetext{
${ }^{8}$ A Guerra de Canudos (1896-1897) representou o conflito entre proprietários de terra e sertanejos nordestinos, guiados pelo líder político e religioso Antônio Conselheiro. O conflito, que teve o apoio da Igreja Católica, resultou no massacre pelo Exército brasileiro da população da comunidade de Canudos, localizada no interior da Bahia e fundada por Antônio Conselheiro (VENTURA, 1997).
} 
processo de valorização, destaca-se a ação da ala progressista da Igreja Católica, capitaneada, na época, por Dom Hélder Câmara, direcionada ao desenvolvimento comunitário e, também, empreendida pelo padre francês Lebret, fundador do movimento internacional Économie et Humanisme, que defendia uma "alternativa humanista e solidária para solucionar os problemas sociais" (VALLADARES, 2005, p. 79).

O desenvolvimento da pesquisa científica no Brasil, a partir da década de 1970, dá novo impulso às representações sociais e aos conhecimentos sobre as favelas. Como ressalta Valladares (2005), a criação do curso de pós-graduação em Antropologia Social no Museu Nacional da Universidade Federal do Rio de Janeiro, em 1968, é um marco importante nesse sentido. Sob a influência do pesquisador americano Anthony Leeds, que, na segunda metade da década de 60, estava na cidade estudando as favelas cariocas, o novo curso de pós-gradução passa a incluir os estudos urbanos como um de seus campos de investigação.

Os conhecimentos técnicos e científicos que servem para orientar ou até mesmo justificar as políticas públicas e suas mudanças relativas às favelas propõem uma visão dessas aglomerações como realidade específica do mundo urbano brasileiro, em particular das grandes cidades. (VALLADARES, 2005, p. 120).

A ampliação das pesquisas sobre favela refletia o espetacular aumento, a partir da década de 50, da população urbana no Brasil, fenômeno que ocorreu, também, em outros países da América Latina. Resultado dessa transição demográfica, a pobreza urbana tornase foco da atenção de numerosos estudos na América Latina e no Brasil e é desenvolvida a teoria da marginalidade a partir dos anos 60 (VALLADARES, 2005).

No próximo item, veremos como se deu essa transição demográfica na América Latina e como a teoria da marginalidade irá explicar a pobreza urbana. Em seguida, mostraremos como ela serviu de inspiração para a política urbana que tratou da questão das favelas no Rio de Janeiro no início da década de 60.

Ainda neste capítulo, mostraremos como a teoria da marginalidade é desconstruída nos anos 70 e no final dos anos 80 , com a abertura democrática, o conceito de exclusão social ganha corpo no Brasil expandindo a análise da pobreza. Por fim, abordaremos como a ascensão do tráfico de cocaína nas favelas do Rio de Janeiro, reforçada com a entrada da cidade na rota internacional do tráfico a partir de meados de 80 , traz um novo significado para a marginalidade e para as favelas. 


\subsection{RIO DE JANEIRO: A MAIOR POPULAÇÃO DE FAVELAS DO BRASIL}

Com 1.393.314 pessoas vivendo em 763 aglomerados subnormais, o Rio de Janeiro é a cidade com a maior população de moradores de favelas do Brasil. (IBGE, 2010). São Paulo, embora tenha um número maior de aglomerados subnormais (1.020), está em segundo lugar, com uma população de 1.280 .400 habitantes morando nesses locais (Quadro 1). Belém, que se destaca, também, por possuir mais da metade de sua população constituída por moradores de favela, tem quase a metade da população de moradores de favela do que tem a cidade do Rio de Janeiro.

Quadro 1 - População nas cidades brasileiras

\begin{tabular}{|c|c|c|c|c|}
\hline Cidade & População total & $\begin{array}{c}\text { População em } \\
\text { aglomerados } \\
\text { subnormais }\end{array}$ & $\begin{array}{c}\text { Percentual de } \\
\text { favelados em } \\
\text { relação à } \\
\text { população total }\end{array}$ & $\begin{array}{c}\text { Número de } \\
\text { aglomerados } \\
\text { subnormais }\end{array}$ \\
\hline Rio de Janeiro & 6.288 .588 & 1.393 .314 & $22,16 \%$ & 763 \\
\hline São Paulo & 11.216 .559 & 1.280 .400 & $11,41 \%$ & 1.020 \\
\hline Salvador & 2.668 .078 & 882.204 & $33,06 \%$ & 101 \\
\hline Belém & 1.392 .332 & 758.524 & $54,48 \%$ & 242 \\
\hline
\end{tabular}

Fonte: Elaborado pela autora com base em IBGE (2010).

A população de favelas do Rio de Janeiro, além de ser a maior do país, vem crescendo, desde os anos 50, há um ritmo bem superior a do restante da população da cidade (Tabela 1).

Tabela 1 - Crescimento da população total e de favela Município do RJ 1950/1991

\begin{tabular}{|c|c|c|c|c|c|}
\hline \multirow[t]{2}{*}{ Anos } & \multirow{2}{*}{$\begin{array}{l}\text { População } \\
\text { do Município } \\
\text { (A) }\end{array}$} & \multirow{2}{*}{$\begin{array}{l}\text { População } \\
\text { Favelada } \\
\text { (B) }\end{array}$} & \multicolumn{2}{|c|}{$\begin{array}{c}\text { Crescimento Populacional } \\
\text { a.a. }(\%)\end{array}$} & \multirow[t]{2}{*}{$\begin{array}{l}B / A \\
(\%)\end{array}$} \\
\hline & & & do Município & da Favela & \\
\hline 1950 & 2.375 .280 & 169.305 & - & - & 7,13 \\
\hline 1960 & 3.300 .431 & 335.063 & 3,34 & 7,06 & 10,15 \\
\hline 1970 & 4.251 .918 & 565.135 & 2,57 & 5,37 & 13,29 \\
\hline 1980 & 5.090 .723 & 722.424 & 1,82 & 2,49 & 14,19 \\
\hline 1991 & 5.480 .768 & 962.793 & 0,67 & 2,65 & 17,57 \\
\hline
\end{tabular}

Fonte: IBGE. Censos Demográficos; Iplanrio, 1991. 
Em relação ao histórico desse crescimento, Ribeiro e Lago (2001) observam que embora a população de favela venha crescendo a uma taxa maior do que a do restante da cidade, as taxas de crescimento de ambas as populações começaram a cair a partir da década de 60. Tal diminuição da taxa de crescimento tanto da população de favela como da população da cidade pode ser interpretada como resultado da retração dos movimentos migratórios do campo em direção à cidade, que tiveram seu período áureo nos anos 40 e 50 .

Essas migrações internas e o processo de urbanização anárquico resultante desse crescimento da população urbana foram responsáveis por impulsionar o crescimento das favelas na cidade a partir da década de 1950. Denominado "superurbanização", esse processo é resultado do rápido inchaço populacional experimentado pela cidade, acrescido da falta de oportunidades de trabalho. (VALLADARES, 2005).

O fenômeno é característico do processo de urbanização que se deu nos países em desenvolvimento, com o descompasso entre a velocidade da industrialização e o aumento da população que migrava das áreas rurais para as cidades. Nas palavras de Mike Davis, seria assim uma expansão urbana 'perversa', resultante da ordem mundial neoliberal que expulsava a mão-de-obra rural para as cidades (DAVIS, 2006).

$\mathrm{Na}$ América Latina, ao contrário do que aconteceu em outras regiões mais desenvolvidas do mundo, como os Estados Unidos (EUA), o desenvolvimento industrial não foi capaz de absorver toda a mão de obra disponível nas cidades. Castells e Portes (1989) fazem essa comparação, avaliando o tamanho da força de trabalho informal nesses lugares. Enquanto nos EUA a categoria conhecida como self-employed (composta de biscateiros, trabalhadores itinerantes e pequenos artesãos) desapareceu no setor industrial, durante o período de acelerado crescimento da industrialização que se deu na virada dos séculos XIX e XX, na América Latina permaneceu constante (um quinto da força de trabalho industrial).

No Brasil, "a força de trabalho urbana [...] cresceu 9,2 milhões, na década de 1950 a 1960, mas 62\% dessa força adicional permaneceu desempregada". (PERLMAN, 1977, p. 33). Em consequência dessa população de desempregados e do crescimento vertiginoso da população de favelados, a autora mostra que, no Brasil, o conceito da marginalidade ganha corpo no senso comum, expressando, nesse caso, um preconceito das classes dominantes em relação às massas populares e uma preocupação pela preservação da ordem social vigente. A partir daí, serve como tema de numerosas pesquisas acadêmicas sobre a pobreza urbana. 
Nessa época, as discussões em torno do conceito de marginalidade apontavam para uma explicação da pobreza urbana como "consequência do massivo êxodo rural [...] que esvaziava os campos das regiões Nordeste e Norte, e 'incharam' cidades [do Sudeste], como Rio de Janeiro e São Paulo" (VÉRAS, 2006, p. 28,). Aos processos migratórios era atribuída a causa de todos os males: "problemas urbanos de moradia (favelas), a mendicância, a delinquência etc." (VÉRAS, 2006, p. 28).

Esse pensamento alinhava-se com as conclusões dos estudos sobre pobreza urbana, realizados pela Escola de Chicago, responsável pelas primeiras pesquisas sociológicas sobre fenômenos sociais urbanos decorrentes do acelerado processo de expansão de cidades americanas no início do século XX. Esses estudos abrem uma nova área de investigação da Sociologia, dedicada exclusivamente à investigação desses fenômenos, a denominada Sociologia Urbana. Dessa forma, temas, como imigração; formação de comunidades segregadas, como os guetos; crescimento da violência e da pobreza nas cidades começaram a ser investigados com profundidade.

Robert Park, considerado um dos grandes nomes dessa escola, foi quem empregou o termo marginalidade pela primeira vez em nível psicológico, no artigo Human migration and the marginal man (1928). A partir de seu interesse pelos movimentos migratórios e consequentes conflitos culturais, Park define o homem marginal como

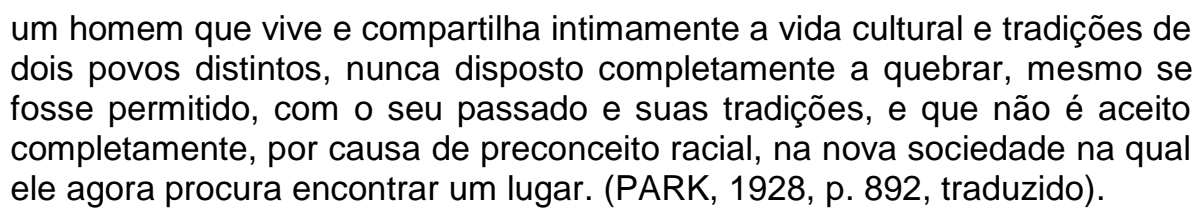

O conceito de homem marginal de Park é desenvolvido a partir da figura do 'estrangeiro', de Simmel (1908), que é

Não o andarilho que vem hoje e vai amanhã, mas o homem que vem hoje e fica amanhã [...] fixado dentro de um determinado círculo espacial. Sua posição espacial dentro dele é particularmente determinada pelo fato de não pertencer a esse lugar e que ele, estrangeiro, traz qualidades que não são e não podem ser nativas dali. (PARK; BURGESS, 1921, p. 322, traduzido).

$\mathrm{Na}$ América Latina, as reflexões sobre as massas marginais urbanas deram origem à teoria da marginalidade que combinava diversas abordagens sobre a pobreza nas cidades. Uma das abordagens predominantes dos estudiosos latinos americanos relacionava a questão da marginalidade ao processo histórico de desenvolvimento e de industrialização do continente.

O sociólogo brasileiro Lúcio Kowarick (1974), por exemplo, um dos autores que contribuiu para essa teoria, sublinhou o problema da inserção precária dos trabalhadores no processo produtivo capitalista latino americano, responsável por um exército de 
desempregados e subempregados. Ao considerar a marginalidade como inerente ao sistema capitalista, Kowarick (1974) explicou que o fenômeno alcançava uma dimensão própria na América Latina devido ao estágio de desenvolvimento do capitalismo e a situação de dependência das sociedades no cenário mundial. Nesses países, o desenvolvimento industrial incapaz de absorver toda a força de trabalho disponível e a tecnologia poupadora de mão de obra, empregada após a $2^{\underline{a}}$ Guerra Mundial, foram responsáveis por um exército industrial de reserva.

Segundo Valladares (2005) as diversas abordagens da teoria da marginalidade tiveram em comum a análise da representação territorial da marginalidade social, que acabou servindo como inspiração para a elaboração de políticas urbanas. Os barrios marginales, que em espanhol significa espaços urbanos semelhantes às favelas, passaram a ser identificados pelos autores latino-americanos como o lugar da pobreza nas cidades e ao mesmo tempo "como manifestação mais típica da não-integração de amplos segmentos da sociedade urbana" (VALLADARES, 2005, p.128).

No Brasil, as discussões sobre a marginalidade acabam materializando-se posteriormente, por meio da política de remoção das favelas (PERLMAN, 1977). Implementada no Rio de Janeiro, no início da década de 1960, durante o governo Lacerda, essa política foi reforçada a partir de 1968, com a criação da CHISAM (Coordenação de Habitação de Interesse Social da Área Metropolitana) (BRUM, 2013). Na próxima seção veremos algumas das consequências dessa política urbana para as populações de favela no Rio de Janeiro. Em seguida, mostraremos como as críticas dos pressupostos da marginalidade no Brasil levaram à desconstrução da própria teoria da marginalidade.

\subsubsection{A REMOÇÃO DAS FAVELAS E SUAS CONSEQUÊNCIAS}

Embora a remoção das favelas não seja objeto deste estudo, algumas das suas consequências serão abordadas, por terem prejudicado ainda mais a integração de seus moradores à cidade. Tal política de remoção, iniciada na década de 1960, não considerou alguns aspectos positivos da vida nas favelas cariocas.

A ocupação das encostas da cidade do Rio de Janeiro, por exemplo, permitiu aos moradores de favelas dessas áreas gastarem menos tempo com o deslocamento para o trabalho, em comparação com o restante da população pobre do município. Uma das consequências da política de remoção, relacionada aos locais dos novos conjuntos habitacionais construídos para receber quem era removido, foi que os moradores passaram a gastar mais tempo para se deslocarem de casa para o trabalho. Essa maior dificuldade de acesso ao trabalho, assim como a serviços e à infraestrutura urbana, 
representou uma perda de qualidade de vida para as pessoas, considerada por Harvey (1973, apud Bursztyn, 2003) como um tipo de renda que, somada à renda monetária, resultaria em uma 'renda real'. Assim, "a [política de] remoção dos pobres para a periferia acarretou um "confisco" da renda real [das pessoas], com perdas evidentes de qualidade de vida". (BURSZTYN, 2003, p. 49).

A remoção das favelas trouxe, ainda, outra consequência, igualmente nefasta: o afastamento das pessoas de suas "redes de parentesco e amizade". Isso dificultou tanto a ajuda mútua entre os moradores como a realização de pequenos biscates na própria comunidade, aumentando o desemprego ( principalmente entre as mulheres, que contavam com essa rede para deixar seus filhos e irem trabalhar) e diminuindo a renda das famílias. (PERLMAN, 1977).

Perlman (2012) afirma que essa política de remoção das favelas foi tão desastrosa para a vida de seus moradores que acabou por produzir, de forma contraditória, a própria população marginalizada que ela pretendia exterminar. Marginalizada por ter deixado de usufruir dos benefícios da cidade e pelo fato de, subitamente, ver-se obrigada a não contar com o capital de que mais dispunha para viver: o capital social.

Ao contribuir para a crítica da teoria da marginalidade, em seu livro Mito da Marginalidade: favelas e política no Rio de Janeiro, a autora explica que essa teoria foi baseada em "um conjunto de hipóteses mal concatenadas e bastante ambíguas" (PERLMAN, 1977, p. 123) a respeito das camadas pobres urbanas. Em sua análise, Perlman parece se referir aos mitos construídos em torno da figura do migrante rural, explicitado por Leeds (1978). Esses mitos que dominavam o ideário do cidadão comum das cidades se referiam ao pobre migrante como um ser preso a valores da vida rural, não familiarizado com o modo de vida urbano, sem apreço ao trabalho e incapaz de traçar planos para o futuro.

Embora a crítica que Perlman faz a esses mitos tenha tido grande repercussão no Brasil e nos Estados Unidos, Valladares (2005) sublinha que Perlman não foi a primeira a se opor à visão dicotômica cidade/favela. Em 1967, Leeds já havia contestado a imagem das favelas vistas como enclaves rurais, isolados no meio da cidade, mostrando que os mitos construídos em torno de seus moradores não correspondiam à realidade, no artigo Brazil and the myth or urban rurality: urban experience, work and values in 'squatments' of Rio de Janeiro and Lima.

Nesse trabalho, depois publicado em português, Leeds (1978) apresenta diversos exemplos de integração de moradores de favela à vida urbana e aponta outras causas para situações de marginalização, rompendo com a explicação errônea que culpa a herança rural 
dessas pessoas pela inabilidade delas em se adaptar à cidade. $O$ autor sublinha os traços estruturais da própria sociedade brasileira como, por exemplo, baixo índice de educação e treinamento das camadas mais pobres e o mau funcionamento das Instituições de Previdência Social como fatores que contribuem para a marginalização do trabalhador pobre.

A pesquisa de campo realizada por Leeds nas favelas cariocas evidencia que a maioria dos moradores desses locais prefere a vida na cidade pelas possibilidades que ela oferece de, por exemplo, mobilidade econômica e programação cultural mais variada. "A cidade é valorizada como o lugar do trabalho par excellence" (LEEDS, 1978, p. 123) e como o lugar onde, por meio do trabalho, a pessoa pode conquistar uma vida melhor. O autor ressalta, ainda, a presença de outros valores, que contradiziam os estereótipos construídos em torno do pobre urbano, como a capacidade de organização expressa, por exemplo, no seu envolvimento nos clubes de futebol e nas escolas de samba.

Ao reforçar a avaliação de Leeds, Perlman (1977) ressalta que os moradores de favela são intimamente integrados ao sistema econômico, tanto em termos de produção como de consumo. No entanto, essa integração é costurada de uma forma que acaba sendo-lhes socialmente injusta, pois, em geral, essas pessoas desempenham trabalhos mal remunerados, e tornam-se mais vulneráveis ao desemprego.

A seguir, veremos que essas discussões em torno da teoria da marginalidade acabaram explicitando sua limitação em explicar a questão social presente nas cidades de uma forma mais ampla. Mostraremos, ainda, de que forma a exclusão social se configurou como um conceito mais abrangente para a compreensão dos múltiplos processos, que levam à fragilização e rompimentos dos laços sociais .

\subsection{POBREZA URBANA: DA MARGINALIDADE À EXCLUSÃO SOCIAL}

Nos anos 1970, o termo marginalidade foi, pouco a pouco, caindo em desuso nos meios acadêmico e político. Em seu lugar, no final dos anos 1980, começa a ganhar corpo o conceito de exclusão social, que passa a abordar a questão social em uma escala muito mais global e a relacioná-la com todas as mudanças em curso, decorrentes das transformações no mundo do trabalho. O processo de globalização trazia em seu rastro a crise do desemprego e a precarização das relações de trabalho, produzindo, assim, uma nova categoria de pobreza: os 'novos pobres'.

O novo conceito de pobreza refere-se a todos aqueles que não conseguem inserção no mercado de trabalho formal: "os desempregados de longa duração que vão sendo 
expulsos do mercado produtivo e os jovens que não conseguem nele entrar, impedidos do acesso ao "primeiro emprego"' (VÉRAS, 2006, p. 19). Dessa forma, a categoria da população não absorvida pelo sistema econômico deixa de ser um problema apenas dos países mais pobres para passar a ser, no limiar do século $\mathrm{XXI}$, um problema do mundo globalizado (BURSZTYN, 2003).

Uma percepção da pobreza mais abrangente se configura. Muito mais abrangente, a pobreza contemporânea rompe os limites dos 'clássicos pobres' ou 'velhos pobres' - no caso do Brasil, os índios, os negros e os trabalhadores rurais (NASCIMENTO, 2003, p. 71), para abarcar "outros segmentos da população pauperizados pela precária inserção no mercado de trabalho" (VÉRAS, 2006, p. 23).

Ao avaliar essa mudança de paradigma, os estudos sobre a questão social das autoras Hayda Alves e Sarah Escorel (2012) atribuem como uma das causas da perda de importância da teoria da marginalidade

[os] [limites geográficos das análises latino-americanas, tanto em função de uma possível barreira linguística, quanto pelo desinteresse dos países centrais em discutir teorias acerca de um problema que os afligia em uma escala muito menor, ou apenas em caráter residual. (ALVES; ESCOREL, 2012, p. 104).

No contexto mundial, ainda nos anos 1980, observou-se o esgotamento de um modelo baseado na 'invenção social', do século XX, que abrigava todos sob o guarda-chuva solidário da proteção social. Se, por um lado, a internacionalização da economia promovia transformações nos processos produtivos que levavam à precarização das relações de trabalho e ao aumento do desemprego, por outro, à medida que se fortalecia a ideologia liberal, encolhia a participação do Estado Providência na economia e aumentavam as desigualdades sociais. Sem acesso a mecanismos universais de proteção social, a pobreza vai se tornando excluída (WANDERLEY, 2001; BURSZTYN, 2003; NASCIMENTO, 2003).

Embora, como pontua Bursztyn (2003), a existência de desigualdades sociais seja quase tão antiga quanto a história da civilização humana, é a partir dos anos 1990 que a noção de exclusão social passa a ser tratada como tema central do debate intelectual, político e midiático (WANDERLEY, 2001; NASCIMENTO, 2003). Tal noção refere-se a

um contingente cada vez maior de pessoas [que] transforma-se de exército de reserva em lixo industrial - não apenas [por] não ter trabalho ou capacidade de gerar renda suficiente como [por não ter][...] as qualidades requeridas para nele ingressar. (NASCIMENTO, 2003, p. 69).

Desde então, a exclusão social passa a ser considerada uma nova manifestação da questão social nas sociedades contemporâneas, fruto de transformações no mundo do trabalho (revolução tecnológica, globalização etc.). 
Diferente das formas existentes anteriormente de discriminação ou mesmo de segregação, [a exclusão contemporânea...] tende a criar, internacionalmente, indivíduos inteiramente desnecessários ao universo produtivo, para os quais parece não haver mais possibilidades de inserção. (WANDERLEY, 2001, p. 25).

A partir da literatura internacional a respeito do tema, pode-se destacar alguns autores franceses que contribuíram para melhor compreensão do processo de exclusão social no final do milênio passado. O primeiro deles é Serge Paugam (2001) que, por meio do conceito de desqualificação social, define a pobreza por seu caráter multidimensional, dinâmico e evolutivo, assim como por ser produto de uma construção social. Ao ressaltar o caráter dinâmico da pobreza, Paugam sublinha que ela deve ser analisada como um processo com origem e efeitos diversos. Dessa forma, aponta para o caráter heterogêneo da pobreza, levando-nos a um paralelo com Valladares, quando esta sublinha o caráter extremamente heterogêneo das favelas. (VALLADARES, 2005).

A desqualificação social, para Paugam, aparece em um "contexto econômico marcado por uma forte degradação do mercado de trabalho", como "um movimento de expulsão gradativa, para fora do mercado de trabalho, de camadas cada vez mais numerosas da população" (PAUGAM, 2001, p. 67-68). O autor sublinha, ainda, a importância do trabalho como se ele fosse o grande vínculo de inserção das pessoas na sociedade, transcendendo, inclusive, em grau de importância, o acesso à moeda.

"Quanto maior é a precariedade profissional, menor é a possibilidade de o indivíduo auferir ajuda do seu meio social" (PAUGAM, 2001, p. 72). Dito em outras palavras, Paugam mostra-nos que o desemprego leva o indivíduo à desqualificação social e, a partir daí, ele vai perdendo a autoestima, os vínculos familiares e sociais e acaba sobrevivendo sozinho em um mundo à parte.

Ao refletirmos sobre a realidade social nas favelas cariocas sob a perspectiva das considerações que Paugam faz acerca do processo de exclusão social, percebemos algumas diferenças entre as conclusões do autor e o que vimos em nossas idas a campo. Essas diferenças, em nosso entender, se devem ao fato de que a desqualificação social associada à pobreza foi identificada, pelo autor, a partir do contexto europeu e da situação dos imigrantes no continente. Em nossas entrevistas com mulheres artesãs, moradoras de favelas da cidade do Rio de Janeiro, constatamos, no lugar do isolamento das pessoas, a existência de grande solidariedade entre elas e forte sentimento de pertencimento a um grupo. Tal realidade, em nosso entender, sinaliza a existência, nas favelas, de uma lógica social diversa que permite as pessoas se ajudarem, até mesmo em momentos de grande dificuldade. E, ainda, destaca que a grande participação da economia informal, no Brasil, 
contribui para que as camadas menos favorecidas da população não se sintam excluídas da sociedade.

Outro autor francês que aprofundou os estudos sobre a questão social, tornando-se referência no debate sobre esse tema, foi Robert Castel. Ele cunhou o conceito de desafiliação, definindo-o como o último estágio de um processo de ruptura social que começa com a perda do trabalho e culmina com a perda dos vínculos sociais. Para Castel, o desfiliado seria aquele que

\begin{abstract}
"não trabalha, apesar de poder trabalhar, no sentido de estar apto ao trabalho. (E) ao mesmo tempo, (...) está cortado de todo apoio relacional. É o errante, o estrangeiro que não pode ser reconhecido por ninguém e se encontra rejeitado, de fato, por toda parte. Consequentemente sobre ele recaem medidas repressivas cruéis, do rechaçamento à exposição à morte, em casos extremos" (CASTEL,1977, p.24).
\end{abstract}

Em sua avaliação sobre a questão social contemporânea, Castel vê o processo de desafilização como uma consequência da relação entre a lógica econômica e a coesão social. E considera que uma desestabilização do indivíduo na estrutura social, devido a transformações no mundo do trabalho, irá levá-lo a um estado de vulnerabilidade tal que culminará com a ruptura das relações pessoais (WANDERLEY, 2001; VÉRAS, 2001) e a perda da sua identidade.

Se o conceito da exclusão social vem à tona nesse debate, trazido pela onda de degradação do mercado de trabalho, ganha asas e passa a se referir não apenas àqueles rejeitados dos mercados materiais e de suas trocas, como também àqueles rejeitados por seus valores espirituais e culturais (WANDELERY, 2001).

A pobreza passa a ser reconhecida não mais apenas em função da renda das pessoas, mas em função de outros fatores, como a falta de acesso a serviços, como educação e saúde, e a liberdade política. Tais privações limitariam as pessoas em poder fazer suas escolhas e viver uma vida digna, como reforça Amartya Sen (2000), autor que apontou os limites da abordagem das desigualdades pelo critério de renda.

"Nos tempos recentes, a abordagem da exclusão tem sido feita, também, sob a ótica da cidadania, e não apenas na perspectiva da economia" (NASCIMENTO, 2003, p. 73). Os excluídos são aqueles que não têm seus direitos assegurados pela sociedade. Vivem de esmola ou de pequenos biscates, para assegurar, na melhor das hipóteses, sua sobrevivência. O grau de invisibilidade social que adquirem é tal que, como bem explica Hannah Arendt, essas pessoas estão em um processo de "recusa ao espaço da obtenção de direitos", ou seja, são pessoas que não têm direitos a terem direitos ou vivem como se não os tivessem. (NASCIMENTO, 2003, p. 62,). 
Embora o termo exclusão social não tenha o mesmo significado que pobreza e desigualdade e possa desenvolver-se fora da esfera desses campos semânticos, os conceitos se relacionam (NASCIMENTO, 2003; WANDERLEY, 2001; ESCOREL, 2009). Como sublinha Escorel,

a maior parte dos processos de exclusão social está relacionada e tem consequências diretas nas condições econômicas dos grupos populacionais, e se fazem mais presentes em situações de intensa pobreza e desigualdades sociais (ESCOREL, 2009).

No caso dos países em desenvolvimento, como o Brasil, que ainda convive com a presença do velho pobre, o novo personagem da pobreza veio reforçá-la ainda mais. Com a abertura democrática dos anos 1980, o conceito de exclusão social ganha corpo, estendendo a análise da pobreza para limites mais abrangentes, além da questão econômica do desemprego, e passando a abranger também uma preocupação com os direitos e oportunidades de cidadania (PERLMAN, 2012).

Embora seja um fenômeno contemporâneo universal, a exclusão social manifesta-se de forma desigual, seguindo o contexto social, cultural e econômico. No Brasil, adquire nuances próprias, devido a características estruturais da sociedade, como a marcante desigualdade social entre ricos e pobres, e a matriz escravista (WANDERLEY, 2004).

A relação entre pobreza, desigualdade social e exclusão social fica bem evidenciada ao se refletir sobre a trajetória histórica do processo de desenvolvimento brasileiro, que produziu um novo tipo de exclusão social, caracterizado pela formação de grupos sociais considerados "desnecessários economicamente [...], incômodos politicamente [...], e perigosos socialmente, na medida em que são vistos como transgressores da lei, bandidos em potencial" (NASCIMENTO, 2003, p. 81).

A representação da pobreza vinculada à bandidagem faz com que excluídos sejam vistos como ameaça social. Essa forma de criminalizar as pessoas acaba por criminalizar o espaço onde elas vivem. Assim, o morador do morro passa a ser visto pelo morador do asfalto como bandido, pelo simples fato de viver na favela. Como explica Valladares (2005), o significado da palavra morro no Rio de Janeiro, desde o início do século $X X$, remete às favelas. Nesse trabalho, usamos o termo "morador do morro" como sinônimo de morador de favela e, por analogia, "morador de asfalto" como morador de outras partes da cidade que não são favelizadas. 


\subsubsection{A VIOLÊNCIA COMO FATOR DE MARGINALIZAÇÃO}

Trinta anos depois de sua primeira pesquisa sobre favelas do Rio de Janeiro, Janice Perlman (2010) em seu último livro sobre o tema - Favelas: four decades of living on the edge in Rio de Janeiro - buscou conferir a presença nesses locais de características dessa nova marginalidade urbana. Perlman refere-se às características da pobreza urbana em cidades do Primeiro Mundo, que dominaram as discussões acadêmicas a partir dos anos 1990: a presença da desigualdade social em um contexto de prosperidade econômica; a existência de uma população não absorvida pelo mercado de trabalho, o enfraquecimento do Estado de Bem-Estar Social e existência de territórios apartados e estigmatizados.

Os resultados dessa nova pesquisa (amostra de moradores de favelas de 30 anos atrás) apontaram para a "persistência intergeracional da pobreza [...] e o crescimento da desigualdade" (PERLMAN, 2012, p. 224) na cidade, no período compreendido entre 1969 e 2001.

A autora explica que nos países que alcançaram a prosperidade econômica, a desigualdade social cresceu, devido à "simultânea eliminação de oportunidades de trabalho para trabalhadores desqualificados e à proliferação de trabalhos para profissionais com formação universitária" (PERLMAN, 2010, p. 158, tradução livre). Já no Rio de Janeiro, a desigualdade manteve-se constante, em um contexto econômico que não pode ser considerado próspero. Ela sublinha que houve retração da economia do Rio de Janeiro, em relação ao período anterior a 1960, devido à mudança da capital para Brasília, à desindustrialização, ao declínio da área portuária, e à mudança do centro intelectual, de cultura e de negócios para São Paulo.

Em relação à população de excedentes de trabalhadores que não consegue ser absorvida pelo mercado de trabalho, Perlman (2010) faz algumas observações interessantes. Embora a pesquisa aponte que "um quarto das famílias da amostra original de favelas tenha um ou mais membro da família desempregado em idade de trabalho" ( $p$. 159), a autora constatou forte presença da economia informal, assim como alto grau de rotatividade no mercado de trabalho formal (turnover) que fazem com que as pessoas não permaneçam inativas.

A retração do Estado de Bem-Estar Social, que ocorreu nos países desenvolvidos do Hemisfério Norte, a autora concluiu não ser característica do processo de empobrecimento 
urbano no Brasil. Perlman sublinha que o país nunca chegou a ter um Estado de Bem-Estar Social forte e que, portanto, não houve retração nos investimentos em programas sociais. Ao contrário, o que se verificou foi uma expansão desses investimentos a partir do governo de Fernando Henrique Cardoso (Bolsa Escola ${ }^{9}$ ), por meio de uma série de políticas de transferência de renda, que culminaram e foram expandidas e consolidadas no governo de Lula, com o programa Bolsa Família, dentre outros (PERLMAN, 2010).

A pesquisadora ressalta, ainda, o peso das aposentadorias nos orçamentos familiares, o que ela denomina de "velho Estado de Bem-Estar". Sua pesquisa mostra que a aposentadoria dos mais velhos representava a principal renda para a maioria dos membros familiares, aproximadamente, $60 \%$ dos entrevistados e $66 \%$ dos chefes de famílias.

Em relação à existência da estigmatização territorial da pobreza, Perlman, em sua pesquisa, mostra que as favelas do Rio de Janeiro continuavam sendo espaços estigmatizados. E, quando comparados com o primeiro período de sua pesquisa, no final da década de 1960, refletiam perda de esperança e unidade entre os membros das comunidades.

No entanto, a autora sublinha que a pobreza, no Rio, diferente daquela dos países de Primeiro Mundo, encontra-se dispersa geograficamente. "As favelas não estão concentradas em nenhuma área da cidade, mas misturadas geograficamente com vizinhanças mais prósperas". (PERLMAN, 2010, p. 160, traduzido). Dessa forma, Perlman (2010) diz que Rio encaixa-se apenas parcialmente no modelo que irá caracterizar a disposição espacial da pobreza urbana nos países desenvolvidos. Se, por um lado, as diferenças nítidas entre morro e asfalto não deixam dúvidas da existência de uma estigmatização territorial, por outro, percebe-se que a pobreza não está concentrada em apenas um local.

Outro fator interessante destacado pela pesquisadora foi que apenas um terço de sua amostra original de pesquisa permanecia morando nas favelas. Esse resultado seria um indicador de mobilidade socioeconômica, ou seja, "uma poderosa prova de que os pobres não estão consignados a chamados 'territórios banidos da fronteira urbana" (PERLMAN, 2012, p. 224). Contudo, mostra, também, uma triste realidade: as pessoas estavam saindo de suas comunidades motivadas, principalmente, pela violência (PERLMAN, 2012, p. 225).

A violência, segundo a autora, provocou uma ressignificação do termo marginalidade na cidade. De condição sociogeográfica, indicando posição marginal na sociedade, o nome

\footnotetext{
${ }^{9}$ A implantação do Bolsa Família como política pública tem sua origem na plataforma de governo, proposta pelo Prof. Cristovam Buarque ao Partido dos Trabalhadores para as eleições de 1989. Com a derrota desse partido nas eleições, o programa foi implantado pela prefeitura de Campinas e pelo governo Distrito Federal em 1995. Posteriormente, em 2001, foi implementada no governo de Fernando Henrique como política pública nacional e incorporada, em 2003, pelo governo de Lula no Programa Bolsa Família.
} 
passou a se referir ao crime organizado e ao tráfico de drogas. "Antes era a pobreza que transformava os residentes de favela em marginais para os olhos dos outros, agora é o tráfico de drogas - devido à proximidade" (PERLMAN, 2010, p. 157, traduzido).

A "penetrante atmosfera do medo" nas favelas cariocas foi a grande diferença encontrada por Perlman, trinta anos após o início de sua pesquisa acerca das favelas cariocas.

Existe uma nova vulnerabilidade física e psicológica. No fim dos anos 1960 as pessoas estavam temorosas de serem removidas de suas casas e comunidades e realocadas à força pelas autoridades da ditadura. Hoje em dia, elas temem morrer nos tiroteios entre policiais e traficantes ou entre gangues rivais (PERLMAN, 2012, p. 225).

O crescimento da violência nas favelas provocou o esvaziamento da presença das pessoas nos espaços públicos dessas comunidades. Sob o domínio do medo, os moradores passaram a ter menos convivência social, visitando menos uns aos outros e participando menos da vida comunitária, com exceção das atividades nas igrejas (PERLMAN, 2012, p. 225).

Perlman destaca que "essa nova forma de violência pode ser a última manifestação da marginalização do pobre, a realidade da marginalidade" (PERLMAN, 2010, p. 162). Como se verá mais tarde, essa violência foi provocada pela entrada de uma nova personagem nesses territórios: a cocaína, que levou o Rio de Janeiro a entrar na rota internacional do tráfico, a partir da década de 1980 (RAMOS, 2005).Embora a presença da droga nas favelas cariocas já existisse desde a década de 1960, ela era tímida e resumia-se basicamente à maconha. Esse cenário muda drasticamente com a entrada da cocaína nessas comunidades e, com ela, a entrada, também, de armamentos pesados. Como mostrou Perlman (2012) e Bryan McCann (2014), essa transformação irá refletir-se na vida dos moradores de favelas de forma "múltipla e perniciosa". A presença tanto de traficantes como, mais tarde, de milícias fez com que essas comunidades se tornassem "espaços em disputa", mudando radicalmente a forma de viver dos moradores e de eles relacionarem-se com o espaço onde moram.

No próximo capítulo, apresentaremos como, em um movimento contraditório à consolidação do processo democrático no país, a violência expandiu-se nas favelas e comunidades populares. Na cidade do Rio de Janeiro, especificamente, ela instalou-se de forma sistêmica nesses locais, envolvendo, além da rede do tráfico internacional, estruturas políticas e policiais. Assim, a violência contribuiu para consolidar esses locais como domínios ilegais, enfraquecendo a aplicação das leis e das garantias de cidadania para os pobres. 


\section{PACIFICAÇÃO DAS FAVELAS: IMPORTÂNCIA DA PAZ PARA A PROMOÇÃO DA}

\section{CIDADANIA}

Ao estudarmos a questão da violência nas favelas do Rio de Janeiro, nos baseamos na definição de violência dada pela Organização Mundial da Saúde (OMS), que evidencia a relação desse conceito com a saúde. Em seguida, a partir de um entendimento mais amplo da saúde, procuraremos destacar a importância da paz para a sustentabilidade. De acordo com a OMS, a violência pode ser definida como:

o uso intencional da força física ou do poder real ou em ameaça, contra si próprio, contra outra pessoa, ou contra um grupo ou uma comunidade, que resulte ou tenha qualquer possibilidade de resultar em lesão, morte, dano psicológico, deficiência de desenvolvimento ou privação (DAHLBERG; KRUG, 2002, p. 5).

No Rio de Janeiro, a violência, durante muito tempo, impôs nas favelas uma atmosfera de guerra, envolvendo uma série de violações de direitos civis e obrigando os moradores dessas áreas a viverem sob o domínio do medo. A existência da violência é evidenciada de diversas formas, que vão desde as alterações na rotina, provocadas pela suspensão das aulas e do atendimento nos postos de saúde, pelo fechamento do comércio e pela completa restrição do direito de ir e vir até graves consequências à saúde.

Além de ferimentos físicos, que levam muitas pessoas à morte prematura, a violência é responsável por várias doenças de fundo emocional. Essa relação fica mais clara ao se analisar a saúde, em uma dimensão holística, tal como propõe a sua definição pela OMS, como a conquista de "um completo bem-estar físico, mental e social e não a simples ausência de doença" (TANCREDI; BARRIOS; FERREIRA, 1998, p. 11). Afinal, o processo de saúde-doença deve ser visto como

um processo social caracterizado pelas relações dos homens com a natureza (meio ambiente, espaço, território) e com outros homens (por meio do trabalho e das relações sociais, culturais e políticas) num determinado espaço geográfico e num determinado tempo histórico. (TANCREDI; BARRIOS; FERREIRA, 1998, p. 11).

Minayo e Souza, em seus estudos acerca do impacto da violência na saúde coletiva, sublinham que a violência, embora não seja um objeto específico da área de saúde, "é um processo social intrinsicamente relacionado a ela, na medida em que the causa diversos agravos" (MINAYO; SOUZA, 1998, p. 520). Entre as consequências mais comuns da ação da violência sobre a saúde, Minayo cita o

estresse emocional que inclui medo, insônia, ansiedade, nervosismo, autoculpabilização, raiva, vergonha, tristeza e depressão e, do ponto de vista da saúde física, doenças cardiovasculares, do estômago, do intestino, dores de cabeça, insônia, dentre outros sintomas (MINAYO, M. C. A lógica 
da guerra e os confrontos armados nas favelas cariocas: depoimento [20 de agosto, 2013]. Rio de Janeiro: Observatório de Favelas. Entrevista concedida a Silvana Bahia).

Considerada um problema de saúde pública, em diversos países, pela Organização Mundial de Saúde (OMS, 2002), a violência passou a ser a segunda maior causa no obituário nacional no Brasil a partir da década de 1980 (MINAYO; SOUZA,1998). Nessa época, a proporção de mortes violentas no país chegou a $29 \%$. Já em relação à morbidade, é mais difícil estabelecer uma medida para os danos causados pela violência.

Minayo e Souza (1988, p.521) ressaltam que suas consequências "não se reduz(em) às lesões físicas e alcança $(m)$ nível incomensurável quando se pensa nas relações e conexões criadas como efeito-causa e causa-efeito". Essas autoras defendem, assim, que a violência, por revelar, em geral, relações sociais conflituosas, deve ser estudada no âmbito de uma "abordagem intersetorial e interdisciplinar", com "contribuições de vários campos profissionais" (1998, p. 522).

Assim como a questão da violência envolve uma visão holística para a compreensão de toda a sua complexidade e, por que não dizer, para a busca de novas estratégias para o seu combate, a promoção da saúde extrapola os cuidados da saúde. Esse é um dos entendimentos explicitados na carta de intenções da Primeira Conferência Internacional sobre Promoção da Saúde, realizada em Ottawa, Canadá, em 1986. A promoção da saúde não deve ser conduzida apenas como uma "responsabilidade exclusiva do setor saúde", pois "vai para além de um estilo de vida saudável, na direção de um bem-estar global" (MINISTÉRIO DA SAÚDE, 2002, p.20).

A saúde, na Carta de Ottawa, é destacada como "o maior recurso para o desenvolvimento social, econômico e pessoal, assim como uma importante dimensão da qualidade de vida" (MINISTÉRIO DA SAÚDE, 2002, p. 20). E uma das condições e recursos fundamentais para sua conquista é a paz.

Durante as discussões que culminaram na adoção dos Objetivos do Desenvolvimento Sustentável, pela ONU em 2015, o Brasil destacou a importância da construção de uma cultura da paz como condição indissociável ao desenvolvimento sustentável. Para isso, o país propôs entre outras ações a promoção de políticas públicas para prevenção e redução de todas as formas de violência e mortes a elas relacionadas (BRASIL, 2015).

A exaltação da paz, embora não apareça de forma explícita nos Objetivos do Desenvolvimento Sustentável, é ferramenta indispensável para a realização de vários desses objetivos. Entre eles, destacam-se os que tratam de assegurar vida saudável e bemestar para todos, os que almejam promover sociedades pacíficas e inclusivas e os que pretendem tornar as cidades e os assentamentos humanos mais seguros. 
A seguir, veremos como a violência cresceu na cidade do Rio de Janeiro, passando a fazer parte de sua dinâmica urbana e contribuindo para aumentar o estigma em torno das favelas. Na sequência, traçaremos uma trajetória das políticas de segurança no Rio de Janeiro que tentaram resolver essa questão, e terminamos o capítulo descrevendo a atual política das UPPs.

\subsection{VIOLÊNCIA COMO PARTE DA DINÂMICA DA CIDADE}

As favelas e as comunidades populares do Rio de Janeiro podem ser consideradas como o "lugar por excelência" de uma violência "sistêmica". Tal violência seria caracterizada como de "caráter endêmico, estruturada tanto por representações sociais como pelas práticas ilegais cometidas regularmente por criminosos e agentes do Estado (muitas vezes, em conluio) e que, em geral, não implica punição para qualquer uma das partes" (PINHEIRO, 2013, prefácio).

No entanto, Alves e Evanson (2013) ressaltam que, embora endêmica nesses locais, a violência não deve ser vista como "intrínseca" a essas comunidades. A violência, particularmente aquela decorrente do tráfico de drogas e da ação das milícias, é uma realidade inegável nessas localidades, mas ultrapassa seus limites. Portanto, para compreendê-la, deve ser vista como "parte (integrante) da dinâmica social da cidade e das suas estruturas políticas e policiais" (ALVES; EVANSON, 2013, p. 31).

Com base nesse entendimento, os autores mostram que apesar das melhorias em infraestrutura que foram implantadas nesses locais a partir do início da década de 1980, a violência nas favelas não foi debelada. Essa conclusão pode ser confirmada aos observamos as taxas de homicídio da Região Metropolitana do Rio de Janeiro levantadas pelo Mapa da Violência - $2012^{10}$ na figura 2 e no quadro 2.

\footnotetext{
${ }^{10}$ O Mapa da Violência é uma série de estudos realizados pela Faculdade Latino-Americana de Ciências Sociais (FLACSO) sobre a violência no Brasil a partir de dados secundários.
} 


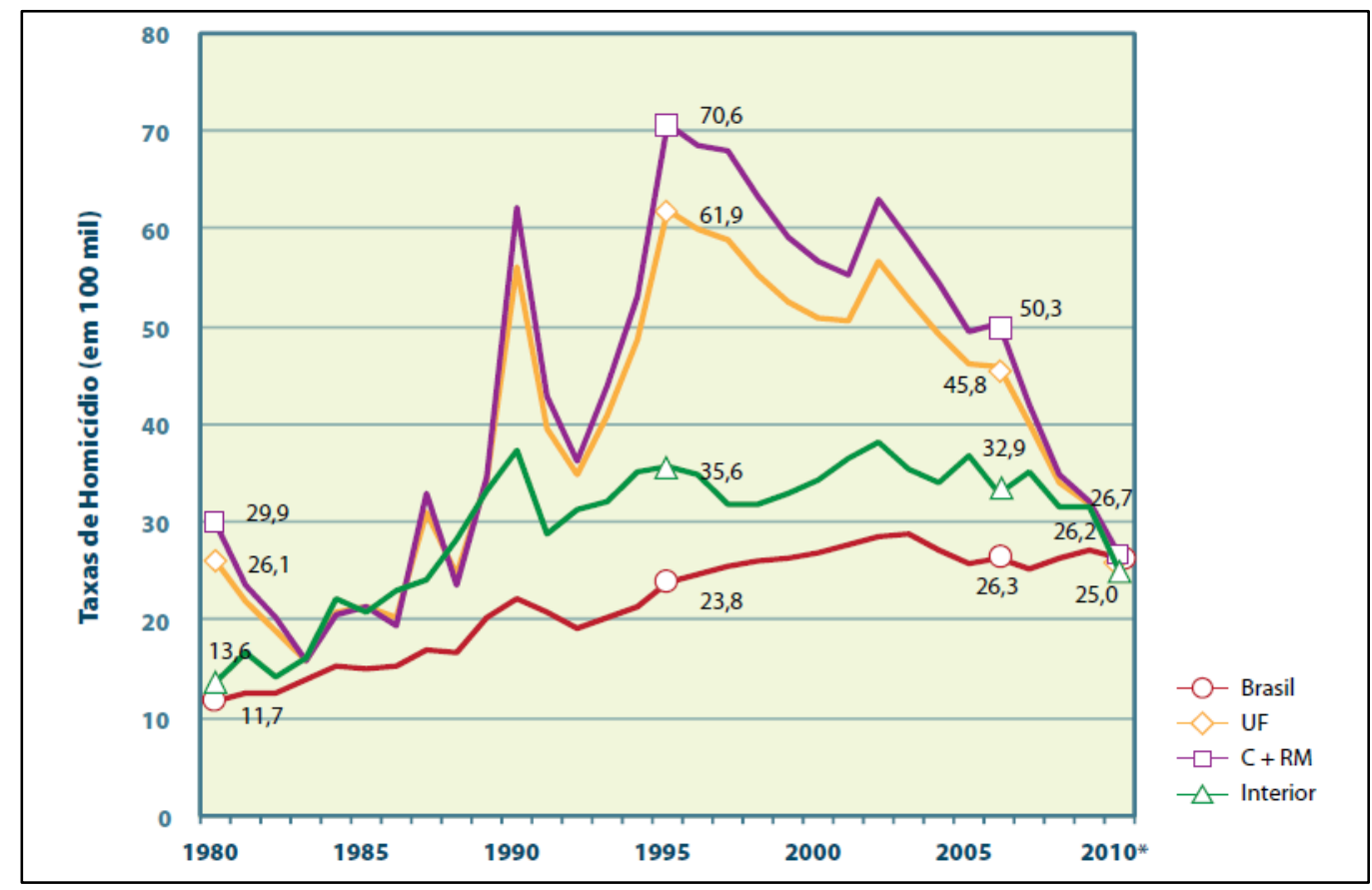

Figura 2 - Taxas de Homicídio por Área. Rio de Janeiro - 1980/2010

Fonte: Mapa da Violência - 2012, WAISELFISZ, 2011

Quadro 2 - Taxas de Homicídio em 100 mil habitantes. Rio de Janeiro 1980/2010

\begin{tabular}{|c|c|c|c|c|}
\hline \multirow[b]{2}{*}{ Ano } & \multirow[b]{2}{*}{ 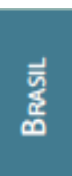 } & \multicolumn{3}{|c|}{ RIO DE JANEIRO } \\
\hline & & 岇 & 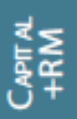 & $\begin{array}{l}\text { 品 } \\
\text { 롶 } \\
\underline{\underline{E}}\end{array}$ \\
\hline 1980 & 11,7 & 26,1 & 29,9 & 13,6 \\
\hline 1981 & 12,6 & 22,0 & 23,7 & 16,7 \\
\hline 1982 & 12,6 & 18,8 & 20,2 & 14,1 \\
\hline 1983 & 13,8 & 15,9 & 15,8 & 16,1 \\
\hline 1984 & 15,3 & 20,8 & 20,4 & 22,1 \\
\hline 1985 & 15,0 & 21,3 & 21,4 & 20,9 \\
\hline 1986 & 15,3 & 20,2 & 19,3 & 23,0 \\
\hline 1987 & 16,9 & 30,9 & 33,1 & 24,2 \\
\hline 1988 & 16,8 & 24,7 & 23,6 & 28,1 \\
\hline 1989 & 20,3 & 34,2 & 34,6 & 33,2 \\
\hline 1990 & 22,2 & 56,1 & 62,2 & 37,2 \\
\hline 1991 & 20,8 & 39,5 & 43,0 & 28,8 \\
\hline 1992 & 19,1 & 35,0 & 36,2 & 31,3 \\
\hline 1993 & 20,2 & 41,0 & 44,0 & 32,0 \\
\hline 1994 & 21,2 & 48,7 & 53,2 & 35,0 \\
\hline 1995 & 23,8 & 61,9 & 70,6 & 35,6 \\
\hline
\end{tabular}

\begin{tabular}{|c|c|c|c|c|}
\hline \multirow[b]{2}{*}{ Ano } & \multirow[b]{2}{*}{ 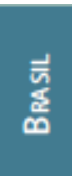 } & \multicolumn{3}{|c|}{ RIO DE JANEIRO } \\
\hline & & 岇 & 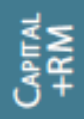 & 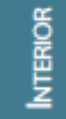 \\
\hline 1996 & 24,8 & 60,0 & 68,6 & 35,0 \\
\hline 1997 & 25,4 & 58,8 & 67,9 & 31,9 \\
\hline 1998 & 25,9 & 55,3 & 63,3 & 31,8 \\
\hline 1999 & 26,2 & 52,5 & 59,2 & 33,0 \\
\hline 2000 & 26,7 & 51,0 & 56,7 & 34,3 \\
\hline 2001 & 27,8 & 50,5 & 55,3 & 36,6 \\
\hline 2002 & 28,5 & 56,5 & 62,9 & 38,0 \\
\hline 2003 & 28,9 & 52,7 & 58,7 & 35,4 \\
\hline 2004 & 27,0 & 49,2 & 54,5 & 33,9 \\
\hline 2005 & 25,8 & 46,1 & 49,4 & 36,9 \\
\hline 2006 & 26,3 & 45,8 & 50,3 & 32,9 \\
\hline 2007 & 25,2 & 40,1 & 41,9 & 35,1 \\
\hline 2008 & 26,4 & 34,0 & 35,0 & 31,4 \\
\hline 2009 & 27,0 & 31,8 & 32,0 & 31,5 \\
\hline $2010^{*}$ & 26,2 & 26,2 & 26,7 & 25,0 \\
\hline
\end{tabular}

Fonte: Mapa da Violência - 2012, WAISELFISZ, 2011

No período estudado para a realização do Mapa da Violência - 2012 (1980 e 2010), percebe-se que as taxas de homicídio da Região Metropolitana do Rio de Janeiro sempre foram superiores as do Brasil. Se no início da década de 1980, tanto a do estado do Rio de Janeiro como a da Região Metropolitana diminuíram, chegando muito próximas a da média 
nacional, a partir de 1984, ambas voltam a se distanciar da taxa nacional. Em 1995, a taxa da Região Metropolitana no Rio de Janeiro atinge o seu ápice com 70,6 homicídios em 100 mil habitantes (WAISELFISZ, 2011).

Bryan McCann (2014) explica a ascensão da violência, ao fazer uma análise histórica do que aconteceu nas favelas do Rio de Janeiro, a partir da década de 1970. Para tanto, ele divide o período em quatro fases: mobilização, reforma, ponto de ruptura e desenlace.

A primeira fase (final dos anos 1970 até a eleição de Brizola em novembro de 1982) é marcada pela mobilização dos moradores de favelas cariocas em torno da ameaça de remoção de suas casas. McCann assinala, como acontecimento desencadeador dessa fase, o movimento de defesa contra a remoção da Favela do Vidigal, ocorrido no final da década de 1970. A partir do sucesso desse movimento, realizado pelos moradores com o apoio da Igreja Católica, o autor mostra como se delineou um movimento maior de mobilização contra a remoção de outras favelas, na cidade do Rio de Janeiro.

Durante a fase de mobilização, McCann lembra que os residentes de favelas passam a lutar para diminuir as desigualdades entre as favelas e a 'cidade formal' do Rio de Janeiro, reivindicando direitos iguais aos dos outros residentes da cidade. O autor destaca o papel político importante daqueles que participaram dessa fase de mobilização, por terem conseguido redesenhar o mapa político da cidade e contribuído para empurrar a nação em direção à redemocratização.

"A onda de mobilização por reforma urbana desencadeada pelo sucesso do Vidigal ajudou a pressionar o governo militar a legalizar a formação de novos partidos políticos em 1980, e a realizar eleições democráticas para governadores de estado em 1982" (McCAN, 2014, p.5, traduzido).

No âmbito estadual, os moradores de favelas apoiaram o governo de esquerda de Leonel Brizola. Com os aliados políticos de esquerda, tentaram alavancar um processo de reforma urbana radical, que envolvia, entre outras reivindicações: a titulação da terra, a educação e a segurança pública (McCANN, 2014).

Alves e Evanson, também, destacam a importância desse período. Se, durante as décadas de 1950 à de 1970, as favelas eram vistas como "infecções no corpo de uma bela mulher", no final dos anos 1970 passaram a ser vistas de forma diferente. Após a fracassada política de remoção, "as favelas passaram a ser vistas como locais ocupados por pessoas que tentam melhorar suas próprias vidas por meio do trabalho árduo, do estudo e da economia" (ALVES; EVANSON, 2013, p. 27).

Assim, no início da década de 1980, o recém-eleito governador Leonel Brizola incorporou em seu plano de governo o planejamento para uma série de melhorias nesses locais, marcando o começo da fase denominada por McCann como reforma. Alves e 
Evanson (2013) ao ressaltarem a importância dessas ações, explicam que Brizola ampliou o acesso de serviços públicos às favelas, tais como o fornecimento de água e eletricidade, e teve como um dos carros-chefes de sua gestão a construção de escolas públicas de horário integral em locais próximos, os Centros Integrados de Educação Pública (CIEPS), idealizadas por Darcy Ribeiro.

Esse processo de urbanização, por meio do qual algumas favelas começaram a ter acesso a alguma infraestrutura pública, continuou na década seguinte, com a implantação de "sistemas de esgoto, creches, postos de saúde, praças públicas e áreas de lazer" (ALVES; EVANSON, p. 27). No rastro dessas melhorias, os autores sublinham, também, que as favelas cariocas testemunham, ainda na década de 1990, o desenvolvimento de organizações sociais fundadas por pessoas da própria comunidade ou de outros lugares.

Já McCann (2014), no entanto, aponta limitações na consolidação desse processo de urbanização das favelas e de expansão dos serviços públicos para seus moradores, iniciado por Brizola. Ele atribui a elas causas externas e internas. Em relação à situação interna do país, diz que a recessão econômica e a hiperinflação no Brasil dificultaram a continuidade das reformas. No âmbito internacional, o tráfico de drogas acabou colocando o Rio de Janeiro em sua rota de comercialização, engendrando, a partir daí, violentas disputas territoriais.

O autor identifica ainda duas falhas estratégicas no cenário local que vieram a prejudicar a consolidação dessas reformas. Uma delas é que houve poucos incentivos para a manutenção da mobilização que reuniu os moradores em torno das reformas urbanas. Essa situação acabou fortalecendo a ação corrupta de intermediários que facilitavam o acesso dos residentes de favela aos benefícios municipais e estaduais. Tal prática reproduzia na "cidade grande" o clientelismo, consolidado ao longo da história no Nordeste (BURSZTYN, 2008). Em consequência, McCann (2014, p.15) afirma que "essas reformas não conseguiram unir a favela à cidade, mas reconfiguraram as fronteiras que as separavam".

Alves e Evanson acrescentam, ainda, que, na contramão do progresso social trazido pelas reformas implantadas nessas áreas, durante o primeiro governo de Brizola (1983 1987), a segurança pública não evoluiu para fazer frente à presença cada vez mais marcante do tráfico de drogas nesses territórios. Os traficantes passam, então, a "mediar desde disputas comunitárias e as relações com o poder estatal para selecionar obras públicas até o patrocínio de entretenimento público e a mobilização de apoio para políticos" (ALVES; EVANSON, 2013, p. 29). 
Ao desempenharem papéis sociais diversos na vida comunitária e envolverem uma intrincada rede de contatos, que acabam por quase legitimar sua existência, esses personagens passam a assumir seu protagonismo nas favelas. Diante dessa realidade, tomada pelo poder de fogo bélico dos traficantes, os autores afirmam que as ações policiais foram ineficazes. A polícia "pode entrar nas favelas e travar algumas batalhas, mas não fica para ganhar a guerra" (ALVES; EVANSON, 2013, p. 29).

Em meados dos anos 1980, McCann (2014) visualiza o prenúncio a terceira fase de sua análise histórica. As guerras de droga e violência tomaram conta do cotidiano urbano. Os líderes do tráfico barganhavam, além das drogas, proteção territorial com armamento pesado, em troca do silêncio dos moradores, tornando-se, assim, os 'senhores das favelas' e destronando o jogo do bicho, como o mercado ilícito mais importante da cidade (MISSE, 2007).

Michel Misse (2007) ressalta que, com o tráfico, a territorialização das transações ilícitas alcançam sua expressão mais forte. A partir daí, a monopolização criminal dos territórios torna-se a nova expressão do abismo que separava a favela do restante da cidade.

McCann (2014) reconhece, ainda, nessa fase, que a coalizão política, que havia dado sustentação para o início do governo de Brizola, já havia sido corroída por disputas que só se avolumavam. Mais precisamente em 1988, o autor diz que a cidade do Rio de Janeiro atinge um ponto de ruptura (breaking point). A cidade, contra a qual até mesmo a natureza parecia conspirar, havia sido devastada por inundações e deslizamentos de terra. O governo municipal de Saturnino Braga (de 1986 a 1988) entrou em falência, tentando responder a essas emergências, imerso em um cenário de hiperinflação.

Segundo McCann, a situação das favelas foi piorando até os anos 1990, atingindo a fase que ele denomina desenlace (unraveling). Nessa fase, era nítido o fim da mobilização que reunia os moradores de favela havia vinte anos. Os líderes do tráfico formaram redes criminosas, que envolviam políticos e representantes civis e usavam as associações de moradores para silenciar as favelas. O autor aponta, também, a participação das organizações não governamentais (ONGs) emergentes que, por não terem força para enfrentar essa situação, acabavam por se ajustar a ela como podiam. Por último, McCann (2014) sublinha o papel das milícias no reforço dessa situação de violência à qual os moradores estavam submetidos, embora elas tenham surgido com a justificativa de expulsar os traficantes.

Alves e Evanson (2013), também, ressaltam a contribuição desses grupos na atmosfera de violência urbana que assolou a cidade do Rio de Janeiro. Compostos por 
policiais corruptos na ativa ou já aposentados, esses grupos impuseram sua presença nas favelas a partir de 2002, prometendo levar a seus moradores o que a tímida presença da lei não conseguia garantir: a segurança.

Por trás dessa promessa, os autores desvendam razões econômicas para as ações das milícias. Ao invés de garantir proteção, elas extorquem os moradores e o comércio local, impondo um regime de lei e ordem não aplicável ao restante da cidade. Estabelecem regras para comercialização e uso de drogas, assim como detêm o monopólio de diversos serviços oferecidos de forma informal para a comunidade, como transportes por meio de vans, distribuição de bujões de gás e fornecimento clandestino de sinal de TV a cabo (ALVES e EVANSON, 2013).

Para mostrar a força econômica e territorial desses grupos, os autores citam uma série de reportagens realizada pelo jornal O GLOBO, na qual as milícias afirmavam dominar, em 2009, "cerca de duzentas das mais de novecentas favelas da zona metropolitana, e sua renda era estimada em 140 milhões de dólares" (AMORA et al, 2012 apud ALVES; EVANSON, 2013, p. 30). Mas o poder dessas organizações não se restringe a essas áreas. Estende seus tentáculos para além das comunidades, chegando à Assembleia Legislativa e à Câmara Municipal, "elas estão inseridas na política partidária, controlam votos e ganham eleições" (ALVES; EVANSON, 2013, p. 30).

O crescimento da violência urbana e a monopolização territorial do crime impuseram novos limites aos direitos dos moradores dessas comunidades. Como mostra McCann (2014), os favelados perderam o direito de escolherem seus próprios representantes políticos e o direito de circularem pela cidade livres da perseguição policial. Essa privação rotineira dos direitos atingiu até mesmo o acesso a serviços públicos.

Desse modo, McCann (2014) diz que as oportunidades para diminuir a fronteira entre as favelas e a cidade, aventadas pelas fases de Mobilização e Reforma, pareciam mais distantes do que nunca. Assim, a imagem das favelas foi congelada como zonas de exceção, onde as regras da lei e as garantias de cidadania não se aplicam.

\subsection{ASCENSÃO DA VIOLÊNCIA NAS FAVELAS CARIOCAS}

Esta pesquisa indica que se existe um momento específico para se abordar 0 aumento da violência nas favelas no Rio de Janeiro, este foi a década de 1980, quando as guerras de drogas e a violência policial ameaçavam a cidade de forma dramática e sem precedentes (MCCANN, 2014; FISCHER, 2008; ALVES; EVANSON, 2013; RAMOS, 
2004). Em 2010, ao avaliar o que mais mudou nas favelas cariocas desde que começou a pesquisá-las, no final da década de 1960, Janice Perlman é enfática: "The most dramatic and devasting change for Rio's poor over the last three decades has been the growth of lethal violence" (2010, p. 165). Enquanto, no final da década de 1960, o maior temor do morador pobre de favela consistia em ver sua casa derrubada e ser obrigado a ir para outro lugar, após 30 anos, esse medo se transformou. O favelado passou a temer pela segurança de sua própria vida (PERLMAN, 2010).

No rastro da pobreza, Perlman (2010) afirma que o tráfico de drogas encontrou nas favelas o ambiente propício para prosperar. Ali, naqueles territórios onde a lei não se fazia presente, os traficantes encontraram o lugar ideal para embalar suas drogas que seriam vendidas aos ricos da cidade ou transportadas para Europa e Estados Unidos.

$\mathrm{Na}$ década de 1980, a cidade do Rio de Janeiro assistiu às primeiras lutas violentas pelo controle do comércio de drogas nas favelas e a uma súbita onda de crimes (FISCHER, 2008). Ramos (2004) acrescenta ainda que, além do tráfico de drogas, a expansão do acesso às armas de fogo contribuiu, também, para o aumento da taxa de criminalidade violenta, nessa época, no Rio de Janeiro e em outros grandes centros do Brasil.

Alves e Evanson (2013, p. 181) confirmam essa percepção, explicando que tal corrida armamentista ocorreu não apenas pelas facções do tráfico como pela própria corporação da polícia. E concluem afirmando que tal fato, combinado ao "aparecimento de uma robusta economia ilegal do tráfico de drogas [...] levou a violência às favelas, desencadeando uma guerra civil na região metropolitana".

Na sequência de horrores que assolaram a cidade, Fischer destaca a ação da polícia que, ao "invés de conter a violência, a perpetua de forma corrupta e brutal" (2008, p. 307, tradução nossa). A autora lembra dois acontecimentos violentos, cometidos por policiais, que tiveram repercussão mundial, o assassinato de crianças de rua nas escadarias da Catedral Candelária (Chacina da Candelária) e o massacre na favela Vigário Geral, ambos no início dos anos 1990. Por causa de todas essas mortes de civis, ela afirma que muitas comunidades passaram a preferir o convívio com os bandidos do que com a polícia.

Ao explicar como a cidade sucumbiu ao domínio da violência, Fischer destaca que, na década de 1980, o tráfico de drogas conseguiu consolidar uma complexa rede de influência, que extrapola a cidade, atravessa as fronteiras nacionais e conecta-se ao tráfico internacional de drogas e de armas. É a partir desse momento que o tráfico passa a impor suas regras nas favelas, determinando o fechamento do comércio na vizinhança e aterrorizando a cidade de todas as maneiras, com demonstrações de força, ateando fogo a ônibus, em vias de grande circulação, e a postos policiais (FISCHER, 2008). 
Se a expansão da violência, a partir da década de 1980, foi um acontecimento comum que ocorreu nos grandes centros urbanos no Brasil, ela não aconteceu de maneira uniforme nessas regiões. Como observa Ramos (2004), é possível perceber "uma geografia da morte", que aponta para as favelas e os bairros pobres das periferias urbanas, o locus predominante desse fenômeno nas cidades brasileiras mais violentas.

Em sua análise sobre as possíveis causas para o súbito aumento da violência nesses locais, Ramos (2004) identifica a ocorrência de vários fatores combinados. Dentre eles, destaca não apenas a expansão do tráfico de drogas e o aumento da utilização de armas de uso militar, tanto por policiais como por traficantes, na luta pelo controle dos pontos de distribuição e venda das drogas, mas, também, a entrada nos centros urbanos e nas grandes cidades do interior, nos anos 1980, de uma nova droga altamente rentável, a cocaína. A autora acrescenta, ainda, que a ausência de poderes públicos, referindo-se especialmente à existência de polícias eficientes e honestos, é outro fator que contribui para tornar essas áreas vulneráveis ao controle territorial exercido pelo tráfico.

O movimento de associações de moradores que se destacou, na década de 1970, por seu importante papel na resistência à política de remoção das favelas, não foi capaz de barrar a expansão e o domínio territorial do tráfico. Os líderes comunitários, antes fortemente articulados com os moradores, na década de 1980, tornam-se "profissionais", passando a "desenvolver laços fortes com os partidos políticos". No entanto, esses laços foram incapazes de garantir a paz e a lei. Na década seguinte, essas associações mostraram toda a sua fragilidade diante da força do tráfico. "Deixaram de promover eleições e começaram a perder sua legitimidade" (ALVES; EVANSON, 2013, p. 29).

Toda essa desorganização da vida comunitária provocada pela inserção do Rio de Janeiro na rota internacional do tráfico de drogas contribuiu para uma "nova era de estigmatização das favelas por parte da mídia e das classes média e alta" (ALVES; EVANSON, 2013, p. 22). Perlman (2010) lembra que a cobertura sensacionalista da mídia sobre a ação dos bandidos reforçou não apenas a criminalização da pobreza como fez com a violência policial passasse a ter uma melhor aceitação pela população.

Será nesta mesma década em que a violência nas favelas se expande a níveis antes nunca vistos, que o país retorna à democracia. Após vinte anos de ditadura militar (19641984), o Brasil tem seu primeiro presidente civil eleito em 1984, por meio do voto indireto. Em 1988, é promulgada a Constituição Federal e um ano depois ocorre a volta das eleições diretas para a escolha do presidente da República. Na próxima seção, veremos que, apesar da consolidação do processo democrático, a violência urbana continuou a crescer. 


\subsection{VIOLÊNCIA, INJUSTIÇA E IMPUNIDADE NA CONTRAMÃO DA DEMOCRACIA}

Com a redemocratização do país, diversas conquistas foram incorporadas à vida dos brasileiros. Exemplo disso é o direito de votar ter-se tornado universal com a Constituição de 1988, que estendeu o sufrágio aos analfabetos. Contudo, Fischer (2008, p. 307), ao avaliar a incapacidade do Estado em oferecer proteção frente à violência anárquica que se espalhou pelo Brasil, assinala que as promessas de cidadania trazidas na esteira desse processo democrático acabaram por esbarrar nas desigualdades econômicas e legais do país.

Diante desse contexto, Fischer (2008, p. 307, tradução nossa) pergunta: "O que significa ser cidadão de um Estado que não consegue nem fazer cumprir as leis nem proteger a vida de seus residentes?" A autora fala do Brasil como pano de fundo, mas afunila sua análise para o Rio de Janeiro. Diz que a cidade, tida como cartão postal do país, é emblemática quando o assunto envolve cidadania e violência.

Assim, enquanto os cariocas aderiam ao movimento de redemocratização que varria o país e muitas ONGs eram criadas com o objetivo de dar voz e representação política à sociedade civil, em um movimento contrário, a violência se expandia pela cidade, dominando os morros e respingando no asfalto.

Por um lado, os cariocas podiam se orgulhar de terem elegido a primeira senadora brasileira negra, e por sua cidade ter se juntado a outras cidades brasileiras em campanhas em prol da urbanização e da regularização das favelas e de outros assentamentos irregulares. Por outro, o Rio de Janeiro era incapaz de enfrentar a estagnação econômica, a inabilidade do governo em tornar suas promessas realidade e a consequente falta de esperança e revolta que tomou conta dos jovens nas favelas. É nesse ambiente que "o tráfico de drogas, assim como outras atividades econômicas ilegais, ganharam combustível para prosperar e se expandir" (FISCHER, 2008, p. 307, tradução nossa).

Fischer (2008, p.308, tradução nossa), então, questiona: "Qual o sentido de falar de cidadania diante desses problemas, especialmente para os pobres cujas vidas foram afetadas mais de perto?". Em sua análise, as contradições da nova era democrática brasileira acabaram por provocar um sentimento de nostalgia naqueles que lutaram por cidadania urbana desde a era Vargas.

Embora reconheça que o país tenha sofrido uma expansão marcante dos direitos, na segunda metade do século XX, a autora questiona a amplitude dessas transformações em 
relação à cidadania. Se por um lado, nos anos 1960, as leis e os direitos de cidadania passaram a ter um significado mais forte para os pobres, e os trabalhadores passaram a ocupar lugar de destaque nas discussões sobre direitos e deveres nacionais, por outro, Fischer (2008) questiona como era possível a existência de qualquer forma de cidadania e democracia sem fortes proteções dos direitos civis.

Ao ressaltar a clássica divisão que T. H. Marshall faz dos direitos de cidadania em civis, políticos e sociais, Fischer (2008) endossa a importância dos direitos civis. Eles são "os direitos necessários para a liberdade individual, liberdade de expressão, pensamento e fé, o direito à propriedade e de concluir contratos válidos, e o direito à justiça" (MARSHALL,1950, apud FISCHER 2008, p. 309, tradução nossa). Ao se basear na experiência histórica inglesa de conquista da cidadania, Marshall explicou a como resultado de um processo que começou com a conquista dos direitos civis, no início do século XIX. Somente a partir daí houve a consolidação dos direitos políticos, no século XIX, e depois a luta pelos direitos sociais no século XX (MARSHALL,1950, apud FISCHER 2008, p. 309, tradução nossa).

Em sua crítica à situação da cidadania no Brasil, Fischer recorre a conexão que o historiador brasileiro José Murilo de Carvalho faz entre os direitos civis e políticos historicamente fracos, no Brasil, e o que ele considera uma cidadania passiva e sem poder. Carvalho (2002) explica que o primeiro governo de Vargas (1930-1945) ao implantar os direitos sociais, por meio da criação da legislação trabalhista e previdenciária, antes da expansão dos direitos políticos, provocou uma inversão da ordem da consolidação desses direitos, descrita por Marshall. Consequentemente, os direitos sociais acabaram representando um significado "ambíguo para o avanço da cidadania" (CARVALHO, 2002, p.124).

Ao mesmo tempo em que a cidadania avançava, nessa época, pois os trabalhadores passavam a ser incorporados pela sociedade, produzia-se uma relação de dependência entre as massas e Vargas. Tal situação era mais evidente, ainda, entre a população pobre urbana que crescia rapidamente devido aos movimentos migratórios. Assim Carvalho caracteriza o populismo de Vargas como "um fenômeno urbano (que) refletia esse novo Brasil (...), distinto do Brasil rural da Primeira República, que dominava a vida social e política até 1930" (CARVALHO, 2002, p.126). Neste contexto, os direitos sociais, no Brasil, que não foram derivados de conquistas políticas, eram vistos pela população como favores que deveriam ser retribuídos. A partir daí, o autor conclui que a cidadania resultante desse processo "era passiva e receptora (ao invés de) ativa e reivindicadora" (CARVALHO, 2002, p.126). 
Fischer (2008) reitera o pensamento de Carvalho, ao analisar as transformações pelas quais o Brasil passou rumo à democracia. Ela mostra que o processo como se deu a construção do conceito de cidadania no Brasil, por meio do qual os direitos sociais foram garantidos, de forma prematura, antes dos direitos civis, teve como resultado uma fragilidade desses últimos.

Sua crítica refere-se, principalmente, à falta de cumprimento das leis, e, nesse ponto, faz dura crítica à justiça brasileira. Nos anos 1990, diante da violência policial, dos "tribunais abarrotados e tendenciosos" e leis "inexequíveis", ninguém esperava que os brasileiros e, especialmente, os brasileiros pobres pudessem contar com infraestrutura legal para fazer cumprir e respeitar suas liberdades (FISCHER, 2008, p. 309).

Embora a autora reconheça uma ampliação dos direitos sociais e um fortalecimento dos direitos civis e políticos, no Brasil, entre a década de 1920 e 1960, ela considera que essa ampliação não foi suficiente para se tornar universal. Aí reside a questão central de sua análise para compreender o contexto histórico do atual impasse da cidadania (FISCHER, 2008, p. 310). O processo de legalização no Brasil foi acompanhado pela persistência de domínios ilegais, que mantinham os pobres "fora da esfera da cidadania".

Teresa Caldeira (2010aㅗ), ao analisar a expansão da violência no Brasil, também, segue nessa direção. Mostra que o processo de consolidação da democracia brasileira veio acompanhado por um 'paradoxal' crescimento da violência nas áreas periféricas das grandes cidades. No caso do Rio de Janeiro, onde as favelas estão incrustadas, também, no meio da cidade, entendemos que elas podem ser incluídas nessa análise.

Embora, aparentemente, paradoxais, violência e democracia se conectam de forma intrincada na história recente do país. O pano de fundo no qual se desenrolam esses dois processos é a transformação das instituições do Estado e da vida econômica e social pelo neoliberalismo. A partir da evolução do processo democrático, Caldeira $\left(2010^{\mathrm{a}}, \mathrm{p} 11\right.$, traduzido) explica que "os significados associados a noções tais como direito e justiça têm permanecido instáveis e discutíveis e também estão associados com práticas sociais bastante contraditórias".

Os espaços urbanos, em especial, as periferias pobres, são apresentados por Caldeira $\left(2010^{a}\right)$ como o locus desse paradoxo. Se é a partir desses locais, com os movimentos sociais, que se fortaleceu o processo democrático brasileiro, é também neles que residem um dos aspectos mais dramáticos desse processo. Afinal, é justamente nas periferias urbanas onde a consolidação da democracia se defronta com seu maior desafio: a expansão da violência. 
No final da década de 1990, o número de homicídios de algumas regiões metropolitanas do país alcançou as mais altas taxas mundiais. Em São Paulo, foram cerca de 65 por 100.000 habitantes ou mais de 6.500 homicídios por ano. Caldeira (2010ª) aponta que a ação policial contribui para isso, sendo "responsável por $10 \%$ dos homicídios na região metropolitana de São Paulo nos últimos vinte anos" $\left(2010^{a}\right.$, p. 20).

Em sua análise sobre a consolidação da democracia no país nas últimas décadas, Caldeira $\left(2010^{a}\right)$ observa que o processo ocorreu de forma irregular. Por um lado, consolidou-se no sistema político, com a adoção de eleições livres e limpas nas duas últimas décadas, a organização livre de partidos políticos e associações, o funcionamento sem censura dos meios de comunicação e a ausência de presos políticos. Por outro, a falta de justiça e a violação dos direitos civis mostram, no rastro desse processo de redemocratização, sinais de fracasso. A justiça e o sistema judicial, assinala Caldeira, "têm sido incapazes de garantir a segurança pública, a justiça e o respeito pelos direitos civis, inclusive nos mínimos níveis" $\left(2010^{a}\right.$, p. 14, tradução nossa). Segundo a autora, isso seria mais visível nas periferias pobres das regiões metropolitanas. No caso da cidade do Rio de Janeiro, onde as favelas permeiam praticamente todos os bairros, pensamos que essa situação não se restringe às periferias.

Caldeira $\left(2010^{\mathrm{a}}\right)$, ao relacionar a expansão da violência e a consolidação da democracia no Brasil, avalia como se deu a evolução dos conceitos de cidadania e dos direitos humanos no país. Em 1996, com a aprovação pelo governo federal do Plano Nacional pelos Direitos Humanos, a noção de direitos humanos muda. Se antes, no imaginário coletivo brasileiro, era associada apenas a um privilégio para poucos, é expandida para um direito de todos, passando a alcançar inclusive grupos marginais.

As forças policiais, segundo Caldeira (2010 a), embora tenham resistido, acabaram sendo afetadas, também, pelo processo de redemocratização em curso. Caldeira cita, como exemplo, o esforço da Polícia Militar do Estado de São Paulo, em mudar sua imagem pública, diretamente associada ao uso abusivo da violência e ao desrespeito aos direitos dos cidadãos. A reforma empreendida fez com que a instituição passasse a adotar algumas medidas novas como a vigilância comunitária. Para isso, a Polícia Militar de São Paulo chegou a apresentar em sua nova página web o que passaria a ser os novos parâmetros das ações policiais: a cidadania e a opinião dos cidadãos. Ela lançou, ainda, o Programa de Melhoria de Qualidade dos serviços prestados à população. Todas essas mudanças reforçam a legitimação que as noções de cidadania e direitos passaram a ter no Brasil contemporâneo (CALDEIRA, 2010ª). 
No entanto, a autora afirma que essa mudança de discurso e da organização da política militar não foi acompanhada por uma mudança efetiva de sua ação. A violência policial continuou depois de 1997, quando foi implementada a nova filosofia gerencial. Caldeira $\left(2010^{\mathrm{a}}\right)$ conclui que o fato de isso ter continuado acontecendo, apesar das "boas intenções e vontades políticas", sinaliza limites na consolidação desse processo de democratização no país.

Em Democracy and violence in Brazil, Caldeira e Holston (1999) destacam o que poderia ser interpretado como uma contradição: o aumento da violência nas cidades brasileiras com a consolidação da democracia. "Desde meados de 80, brasileiros percebem a criminalidade violenta como o principal problema que afeta suas cidades. Não somente os crimes aumentaram nesse período, mas o tipo de criminalidade mudou" (1999, p. 696, traduzido).

O crime havia se tornado mais organizado e mais violento e "a violência policial alcançou níveis nunca antes vistos" (CALDEIRA; HOLSTON, 1999, p. 695). Corrupção, envolvimento com o crime organizado, métodos violentos e ilegais de abordagem e investigação mostravam que a polícia era incapaz de garantir a segurança da população.

Caldeira e Holston (1999), assim como Fischer (2008), explicam que essa aparente contradição marcou a expansão da democracia no Brasil, assim como a de outros países latino-americanos, como um descompasso entre o processo de democratização da política e a conquista dos direitos civis.

Embora suas instituições políticas tenham se democratizado com considerável sucesso e embora tenham promulgado constituições e códigos legais baseados no Estado de Direito e valores democráticos, o componente civil da cidadania permanece seriamente enfraquecido, visto que os cidadãos continuam a sofrer violações sistemáticas de seus direitos (CALDEIRA; HOLSTON, 1999, p. 692, traduzido).

Assim como Marshall (1950), os autores referem-se aos direitos civis como a "esfera dos direitos, práticas e valores que dizem respeito à liberdade [...] e à justiça como meios para [se assegurar] outros direitos que seriam a base do Estado democrático de direito" (CALDEIRA; HOLSTON, 1999, p. 693, traduzido). Os princípios de liberdade e justiça dariam corpo e essência à noção de cidadania, possibilitando, assim, azeitar-se a complexa relação entre Estado e sociedade.

Como resultado da falta de garantia dos direitos civis, Caldeira e Holston (1999) afirmam que essas democracias estariam sujeitas

à deslegitimação de muitas instituições de lei e justiça, uma escalada do crime violento e abuso policial, a criminalização do pobre, um significante aumento do apoio para medidas ilegais de controle, obstrução generalizada 
(pervasive) do princípio da legalidade, uma desigual e irregular distribuição dos direitos dos cidadãos (CALDEIRA; HOLSTON, 1999, p. 695, traduzido).

Por essa razão, os autores irão dizer que essas democracias seriam disjuntivas: "ao denominá-la disjuntiva, [...] chamamos atenção para seus processos contraditórios de simultânea expansão e desrespeito aos direitos da cidadania" (CALDEIRA, 2000, p. 343).

A existência de instituições fracas e descreditadas no Brasil que não conseguem fazer valer a lei é um dos resultados dessa consolidação democrática contraditória. Ao fazerem uma crítica contundente ao 'ineficaz' sistema judiciário brasileiro, Caldeira e Holston afirmam que, no Brasil, "a justiça é exercida como um privilégio da elite, os direitos individuais e civis são deslegitimados e as violações dos direitos humanos (especialmente pelo Estado) são rotina" (2000, p. 375).

Outra questão levantada por esses autores é a existência de uma polícia corrupta e violenta no Brasil.

As forças da lei e da ordem são elas próprias um dos principais agentes de violência em muitas cidades. Várias forças policiais são atormentadas pela corrupção, enredadas com o crime organizado e acostumada a métodos ilegais e violentos de ação (CALDEIRA; HOLSTON, 1999, p. 695, traduzido).

Assim, a polícia, em vez de garantir a segurança nas cidades, acaba contribuindo para perpetuar a violência como parte da experiência diária das pessoas e incrementando a 'cultura do medo'.

Essa situação de violência levou a população a apoiar a adoção "de políticas questionáveis do ponto de vista da consolidação democrática" (CALDEIRA; HOLSTON, 1999, p. 695, traduzido), como o uso das Forças Armadas para combater a criminalidade. Como exemplo, os autores citam a Operação Rio 1994, quando as Forças Armadas foram enviadas para o Rio para conter o avanço do tráfico e controlar a violência (SILVA, [2003]; CALDEIRA; HOLSTON, 1999).

Jorge da Silva, ex-chefe do Estado-Maior Geral da Polícia Militar do Rio de Janeiro e ex-secretário de Estado de Direitos Humanos, sublinha o papel importante que os meios de comunicação tiveram na legitimação da atuação das Forças Armadas, reforçando o apelo da sociedade pelo uso delas no combate à violência.

Na segunda gestão Brizola (de 1991 a 1994), a questão da segurança pública parecia ter fugido ao controle (ALVES; EVANSON, 2013, p. 200). “Em (...) 1994, as taxas de homicídio vinham subindo no estado, tendo ultrapassado naquele ano a cifra de 8 mil" (SILVA, [2003]). Naquele ano, o advogado e professor de Direito Penal Nilo Batista assumiu o governo do estado, em substituição a Leonel Brizola, que havia se licenciado para 
concorrer à Presidência da República. Nilo Batista formalizou um acordo com o governo federal para viabilizar a Operação Rio, que permitiu a participação das Forças Armadas no combate ao tráfico e ao crime organizado.

O resultado da Operação Rio mostrou que não era com esse tipo de política de enfrentamento que se resolveria a questão da violência no Rio de Janeiro. Jorge da Silva explica que "no ano de 1995 foi batido o recorde histórico de assassinatos (8.348) no Estado do Rio de Janeiro" (SILVA, [2003].

Por meio dessas experiências e da adoção de outras demonstrações de força, tais como a prática de tortura para a obtenção de confissões ou de atos da justiça que permitem o arrombamento de casas circunvizinhas, é possível concluir que a conquista da democracia política no Brasil foi insuficiente para a existência de uma democracia legítima e eficaz. Como Caldeira e Holston (1999) explicam, para a democracia brasileira, de fato, consolidarse, seria necessário que ocorressem mudanças sociais e culturais profundas na sociedade.

Tais mudanças implicariam, também, em uma política de segurança pública diferente que resultasse em uma nova abordagem da prática policial diante da violência urbana. A seguir, veremos algumas tentativas nesse sentido que foram adotadas no Estado do Rio de Janeiro, a partir de meados da década de 1980, até chegarmos a adoção da atual política de segurança pública iniciada em 2008.

\subsection{POLÍTICAS DE SEGURANÇA DO RIO: ENTRE O RESPEITO AOS DIREITOS HUMANOS E O TREINO PARA MATAR}

$\mathrm{Na}$ pesquisa que realizaram sobre a violência policial no Rio de Janeiro, Alves e Evanson (2013) destacam a militarização da polícia, que foi incorporada às forças armadas durante a ditadura militar, como uma das principais causas para uma prática policial repleta de equívocos.

A ditadura sequestrou, de fato, a polícia para seus próprios fins e acabou com qualquer noção de policiamento de bairro. As principais tarefas atribuídas aos PMs foram desencorajar e reprimir a oposição e proteger 0 regime, em vez de proteger o povo (ALVES; EVANSON, 2013, p. 190).

Os autores explicam que, embora tenham ocorrido, depois de 1988, ações pontuais para "a reforma da polícia e a substituição da ideologia estatal de segurança nacional da ditadura pelos princípios do Estado de direito e da proteção dos direitos dos cidadãos" (ALVES; EVANSON, 2013, p. 190), na prática a polícia não havia mudado. O que mudou foi 
o alvo. O novo inimigo interno a ser combatido deixou de ser os opositores ao regime e passou a ser os traficantes.

Regidos por uma lógica bélica, "os policiais são treinados para matar" (ALVES; EVANSON, 2013, p. 191) como em uma guerra, cujos territórios são áreas da cidade densamente ocupadas. Dessa forma, a polícia deixa de adotar uma política mais condizente com a nova realidade democrática no Brasil, deixando de exercer o papel de mediadora de conflitos nas comunidades e de responsável pela garantia da segurança dos cidadãos para adotar um comportamento classificado pelos autores como irracional e truculento. Tal comportamento resultaria, por exemplo, principalmente nas comunidades mais pobres, em graves violações dos direitos humanos e participação em esquemas de corrupção, desde a prática de extorsão, para que as transações comerciais de drogas ocorressem livremente, até mesmo à venda de armas pesadas para traficantes.

Outra questão crítica para a segurança pública, verificada na pesquisa de Alves e Evanson (2013), é a falta de interação entre as polícias militar e civil, que contribui para uma atuação ineficiente de ambas.

Nem uma nem outra completam o ciclo de trabalho. A Militar está nas ruas para reprimir o crime e confrontá-lo, se necessário. A Civil, [...] investiga os crimes, mas os inquéritos são limitados. Ela tem a reputação de não solucionar os casos, restringindo-se a extrair confissões de suspeitos por meio de tortura em prisões localizadas em delegacias, mesmo que tanto as prisões em delegacias quanto a tortura sejam ilegais. (ALVES; EVANSON, 2013, p. 193).

Todos esses indícios de uma prática policial não condizente com a garantia dos direitos de segurança e proteção do cidadão explicitam a urgência de uma reforma na instituição da polícia. Porém, ao analisarem o histórico das políticas de segurança pública no Rio de Janeiro, antes da atual política de pacificação das favelas, os autores explicam que "nenhum governador [...] no período democrático iniciado em 1988 realizou um plano abrangente para reformar a polícia" (ALVES; EVANSON, 2013, p. 199).

Alves e Evanson (2013) lembram que o ex-governador Leonel Brizola, em seus dois mandatos, chegou a tentar, se não uma reforma radical, fazer com que a polícia observasse a lei, sem agir com arbitrariedade. Brizola pretendia garantir ao morador de favela o direto de ser respeitado tal qual o cidadão do asfalto. Com essa visão, o governador procurou, também, ampliar a oferta de serviços básicos, como energia elétrica e saneamento das favelas.

No entanto, o que viria a marcar o seu governo foi a aposta na educação das crianças pobres como uma saída para a violência. Para isso, Brizola construiu "centenas de CIEPS, popularmente conhecidos como Brizolões, em comunidades pobres, em sua maior parte" 
(ALVES; EVANSON, 2013, p. 199). Idealizados por Darcy Ribeiro e com projeto arquitetônico de Oscar Niemeyer, os Centros Integrados de Educação Pública eram a concretização de um projeto educacional que tinha tudo para revolucionar a educação pública no Brasil. Contudo, os governantes que sucederam o ex-governador não lhe deram continuidade. Os CIEPs tinham como proposta oferecer ensino de qualidade em horário integral para as crianças da rede estadual de ensino, com atividades culturais, estudos dirigidos e prática de esportes, além das aulas do currículo regular.

Em relação à política de segurança pública, destacam-se duas ações da gestão de Leonel Brizola. A primeira foi a nomeação do coronel Carlos Magno Nazareth Cerqueira para o comando da PM, um oficial negro, que propôs uma mudança significativa na atuação da polícia. Defensor dos direitos humanos e inimigo da corrupção policial, Cerqueira durante os dois mandatos de Brizola defendeu "um modelo de policiamento comunitário pelo qual a polícia se torna uma presença permanente em uma região e trabalha de perto com os moradores para conquistar a confiança e reduzir os crimes" (ALVES; EVANSON, 2013, p. 199).

Cerqueira é apontado como o responsável pela introdução de novas ideias para o exercício da segurança pública no Brasil, com base na produção acadêmica internacional sobre policiamento comunitário. Além de ter contribuído para a formação de uma nova corrente de pensamento dentro da polícia, suas ideias deram origem a projetos como o do Grupamento de Aplicação Prático-Escolar (GAPE), na década de 1990. O GAPE funcionava como uma espécie de estágio para policiais recém-formados ou em formação. O objetivo do projeto era aproximar os policiais da realidade das favelas marcadas pela violência do tráfico, "no sentido de produzir um conhecimento acerca das regras de sociabilidade, histórias de vida, trajetórias e condições de existência, ou seja, fatores que permitissem a "compreensão" do fenômeno da criminalidade local - e suas condicionantes sociais - e, por extensão, a sua superação ou diminuição" (VIVA RIO, 2014, p12). Ao propor um policiamento diferente dentro das favelas, o projeto foi inovador. Ao invés das conhecidas 'batidas' policiais pontuais, a presença da polícia nesses locais passou a ser constante nesses locais, durante o período diurno (OLIVEIRA; ABRAMOVAY, 2012).

A redução da violência policial contra os moradores das favelas foi um dos maiores méritos do legado de Cerqueira (McCANN, 2014). Suas ideias impactaram a própria instituição, servindo de modelo para um grupo de oficiais (ALVES; EVANSON, 2013). São retomadas pela política de segurança pública das Unidades de Polícia Pacificadora (UPPs), com a diferença de que, atualmente, essas propostas estão sendo implementadas com muito maior comprometimento e com maior aporte de investimentos para persuadir tanto 
policiais como residentes de "sua viabilidade e de sua permanência" (McCANN, 2014, p. 188).

Além da reforma da polícia, a política de segurança pública durante a gestão de Brizola foi marcada pela reforma do sistema prisional, implementada pela socióloga Julita Lemgruber, no período entre 1991 e 1994. Escolhida por Brizola para dirigir o sistema penitenciário do Rio de Janeiro, Lemgruber se destacou por defender penas alternativas para crimes não violentos e por reconhecer a importância da participação de especialistas civis na execução de programas de segurança pública (ALVES; EVANSON, 2013).

Apesar dessas duas ações positivas, Brizola, em seu segundo mandato (1991-1994), demonstrou perder o controle sobre a segurança pública. Nesse período, duas chacinas realizadas por policiais chocaram a cidade: a de Vigário Geral e a da Candelária. Na primeira, "21 pessoas foram mortas por vingança pelo assassinato de quatro soldados por traficantes, de quem os PMs tentavam extorquir dinheiro" (ALVES; EVANSON, 2013, p. 200). Na outra, nove crianças e adolescentes que viviam nas ruas próximas à Catedral da Candelária foram assassinadas. $O$ ato bárbaro desvelou outra face da cidade tida como maravilhosa, manchando sua imagem no âmbito internacional e provocando uma forte resposta da sociedade civil.

Os governos de Wellington Moreira Franco (1987-1990) e de Marcelo Alencar (19951998) foram marcados pela adoção de políticas "linha-dura" no combate à criminalidade. Tal oscilação extrema entre diferentes estratégias de combate à criminalidade, observadas no Rio de Janeiro, desde 1983, irão caracterizar a política de segurança pública do estado (ALVES; EVANSON, 2013; COSTA, 2004).

Os resultados insatisfatórios das políticas repressivas dos governos de Franco e Alencar mostram que, se Brizola, com suas boas intenções em prol da reforma da polícia, não foi capaz de conter a violência, a repressão, como carro-chefe, também não resolveu a questão. No governo de Franco, houve "um aumento dramático dos homicídios e das ações dos esquadrões da morte. Em 1990, as taxas de homicídios chegaram a patamares sem precedentes" (ALVES; EVANSON, 2013, p. 201). Já no governo de Alencar, a política de segurança pública foi entregue nas mãos do general Nilton Cerqueira, da época da ditadura, em uma tentativa de resolver a criminalidade, por meio do incentivo ao extermínio de bandidos.

Em 1999, a política de segurança pública do Rio sofre mais uma mudança radical. O governador Anthony Garotinho (1999-2002), recém-eleito, lança um programa de reforma da polícia, que tinha com base "mudanças que combinavam segurança pública e direitos humanos". Para a implantação do programa foram escolhidos dois nomes chaves: o 
antropólogo Luiz Eduardo Soares, que assumiu o cargo de subsecretário de Segurança Pública e Julia Lemgruber, que passou a ser a primeira ouvidora da polícia do Estado do Rio. Soares havia liderado o processo de elaboração das propostas de reforma, encaminhadas por um grupo de especialistas. (ALVES; EVANSON, 2013, p. 202). Contudo, a reforma foi frustrada quando Soares foi demitido por denunciar casos de corrupção na polícia carioca (SOARES, 2013).

No âmbito desse programa de reforma, em 2000, foi realizada uma nova experiência de policiamento comunitário em duas favelas da Zona Sul da cidade: Cantagalo e Pavãozinho. O GAEP tinha, assim como o Gape, uma proposta de atuação diferente da polícia de confronto. Por meio da presença permanente da polícia nas favelas, o GAEP propunha uma ação preventiva para evitar a aproximação dos jovens com o crime e tinha como objetivos "a desmobilização de traficantes armados; a produção de uma cultura de intolerância ao ingresso de menores em atividades criminosas; e a produção de uma cultura de intolerância em relação à corrupção de policiais pelo tráfico de drogas" (VIVA RIO, 2014, p.13).

A experiência conseguiu diminuir a violência nessas duas comunidades, acendendo uma luz de esperança para os cariocas. Mesmo sem resolver questões mais estruturais da criminalidade, no Rio de Janeiro, devido ao tráfico, a simples presença da polícia nesses territórios onde a lei não se fazia valer contribuiu para a mediação de conflitos e para a proteção contra disputas armadas. "Durante os dois anos que se seguiram, não houve um único registro do tipo [mortes violentas], nem balas perdidas atingiram essas localidades" (ALVES; EVANSON, 2013, p. 203).

Posteriormente, o GAEP foi levado a outras favelas. No entanto, embora a experiência tenha sido considerada bem sucedida em sua fase inicial, seu êxito não prosperou com a ampliação do projeto. Pesquisa realizada pela ONG Viva Rio, com base em entrevistas com coronéis reformados da Polícia Militar do Rio de Janeiro, aponta como principal razão para a experiência ter fracassado o esvaziamento do efetivo. A não geração de novos quadros para o novo projeto era um dos resultados do projeto ter sido implementado sem ser uma política de governo (ou de Estado). Além disso, o projeto funcionou sem uma estrutura administrativa própria até 2006 , o que dificultou a unificação dos procedimentos e orientações (VIVA RIO, 2014).

Alves e Evanson explicam que "as iniciativas do Grupamento de Policiamento em Áreas Especiais (GPAE) foram bastante limitadas, pouco abrangentes, restringiram-se a 
programas-piloto ou a tentativas de melhorar a imagem ruim da corporação" (ALVES; EVANSON, 2013, p. 203). Entre as dificuldades encontradas, os autores apontam para o fraco apoio institucional da PM, a participação de policiais "problemáticos" e a resistência da "linha-dura" da PM em relação a esta nova atuação da polícia.

O governo seguinte foi o de Rosinha Garotinho (2003-2006). Elevados níveis de violência e corrupção policial marcaram sua gestão, mostrando que o plano de reforma lançado por seu marido no governo anterior estava definitivamente sepultado. "Dois chefes da Polícia Civil e o chefe da Polícia Rodoviária do estado foram presos e acusados de vários crimes" (ALVES; EVANSON, 2013, p. 204).

Em 2006, Sérgio Cabral assume o governo, que teve como um dos principais alvos de campanha a questão da segurança pública. Com o experiente José Mariano Beltrame à frente da Secretaria de Segurança Pública, Cabral adota uma política de confronto com os traficantes. Beltrame tinha na bagagem 30 anos de Polícia Federal, onde dirigiu um programa de inteligência para mapear o crime organizado. Para ele, as favelas eram locais onde a ausência do Estado contribuía para que os criminosos governassem. Sua indicação selaria uma parceria entre o governo federal e o estadual para melhorar a segurança pública (ALVES; EVANSON, 2013).

Tal política de confronto, baseada na entrada da polícia nas favelas, em busca dos traficantes, tampouco teve bons resultados. "Em 2007, pela primeira vez, o número de homicídios no Rio superou com folga os valores registrados no estado de São Paulo e os grupos criminosos continuavam fortes" (ALVES; EVANSON, 2013, p. 205). Foi nesse ano, também, que o Governo do Estado do Rio de Janeiro resolveu montar uma operação de guerra para fazer um cerco policial no Complexo do Alemão, com o objetivo de reprimir o tráfico de drogas na região. O Complexo do Alemão, considerada uma das maiores favelas do Rio de Janeiro é, na verdade, um aglomerado de favelas, composto por dezesseis comunidades. A operação prolongou-se até o fim dos Jogos Pan-Americanos, durou quatro meses, e contou com a ajuda do governo federal, que enviou 1.280 homens da recém-criada Força Nacional de Segurança Pública (FNS) (ALVES; EVANSON, 2013; SILVA ${ }^{\mathrm{a}}$, 2012).

De acordo com dados oficiais, 19 pessoas morreram e muitas ficaram feridas nesse cerco policial ao Complexo do Alemão (SILVA ${ }^{a}$, 2012). Jaílson de Souza e Silva, um dos criadores do Observatório das Favelas, considera a operação policial o auge de uma política de segurança equivocada, baseada em "uma lógica bélica crescente" e na repressão ao tráfico nas favelas. 
Todo [...] esforço e perdas derivadas não provocaram impacto algum sobre o comércio de drogas ilegais. Pelo contrário, o Brasil - com destaque para o Rio de Janeiro - se tornou um território de importância no comércio internacional de drogas, como mercado de consumo e como rota do tráfico (SILVA ${ }^{\mathrm{a}}$, 2012, p. 422).

Como explicam Alves e Evanson (2013), já que a ação policial não envolvia uma presença permanente do efetivo nessas comunidades, quando a polícia se retirava, os locais eram novamente tomados por traficantes e outros bandidos. Além de não combater o controle territorial dessas áreas por parte dos criminosos, tal política de enfrentamento bélico nas favelas teve como aspectos negativos a falta de objetivos claros que possibilitassem uma avaliação de sua implantação. Como resultado, os moradores das favelas vivenciaram o aumento da violência policial, com um grande número de feridos e inocentes mortos (ALVES; EVANSON, 2013; SILVA ${ }^{\mathrm{a}}$, 2012).

Toda essa situação, explica Julita Lemgruber (2010), em entrevista à revista TPM, fez com que os dois primeiros anos do governo de Cabral, assim como os governos de Garotinho e Rosinha pudessem ser descritos como "uma tragédia para o Rio de Janeiro. Um período de extrema violência policial". Lemgruber, que já havia dirigido o sistema penitenciário do Rio de Janeiro, no período de Brizola, e sido ouvidora da polícia do Rio de Janeiro, na gestão Garotinho, diz que, depois do ocorrido, "eles se deram conta que combater violência com violência não leva[ria] a lugar nenhum" (LEMGRUBER, 2010).

O fracasso da ação coordenada entre o governo estadual e o governo federal no Complexo do Alemão e a reação social que gerou marcaram se não o fim de um paradigma de violência policial, o prenúncio de uma mudança necessária na política de segurança pública do Estado do Rio de Janeiro (SILVA ${ }^{a}$, 2012). Em 2008, dois acontecimentos contribuíram para o início dessa mudança.

Em maio daquele ano, a tortura de dois repórteres e de um motorista do jornal O Dia por milicianos que atuavam na favela do Batan, na Zona Oeste da cidade do Rio de Janeiro detonou um fato histórico, a instauração da CPI das milícias na Assembleia Legislativa, sob a presidência de Marcelo Freixo. Era a "primeira vez na história recente do Rio de Janeiro, [que] era efetivada a perseguição dos principais membros daquele grupo de criminoso" (SILVA, 2012, p. 424). Tal ação teve como consequência o abalo do apoio político que os milicianos tinham na política municipal e estadual, com "a prisão e cassação de mandato do vereador Jerônimo Guimarães Filho, o Jerominho, e do seu irmão, o deputado estadual Natalino Guimarães" (SILVA ${ }^{a}, 2012$, p. 424). Além disso, os principais líderes desse grupo criminoso foram presos a partir daquele ano.

Outro acontecimento importante naquele ano foi o lançamento, pelo governo federal, do Programa Nacional de Segurança Pública com Cidadania (Pronasci), um plano de 
segurança pública nacional que consistia, inicialmente, em um pacote de 94 programas e que, posteriormente, foi estendido para 97. Como sublinham Alves e Evanson, o plano marcava o maior envolvimento do governo federal com a questão da segurança pública e foi concebido em resposta às duras críticas que o país recebia da ONU em relação ao tema. $O$ Brasil, embora reconhecido por seus programas sociais, não havia conseguido avançar na questão da segurança pública.

Em 2008, o relator especial de Execuções Extrajudiciais, Sumárias ou Arbitrárias das Nações Unidas, Philip Alston, escreveu um relatório mostrando a situação da violência no Brasil e alertando o quanto ela era incompatível com as conquistas democráticas.

"Os brasileiros não lutaram bravamente contra 20 anos de ditadura, nem adotaram uma Constituição Federal dedicada a restaurar o respeito aos direitos humanos apenas para que o Brasil ficasse livre para que os policiais matassem com impunidade, em nome da segurança" (ONU, 2008, p.2).

Em suma, o relatório alertava para os altos índices de homicídio no Brasil (mais de 48.000 pessoas mortas anualmente), um dos mais elevados do mundo. O texto destacava, entre os estados mais violentos, o Rio de Janeiro e Pernambuco, por possuírem taxas de homicídio mais altas do que a média nacional. Atribuía como uma das causas da violência no Rio de Janeiro, a ausência do Estado nas favelas, permitindo que facções criminosas tomassem o controle das comunidades e montassem um poder paralelo. Criticava as operações policiais de grande porte organizadas pelo Estado do Rio de Janeiro, entre 2007 e 2008, para a retomada do controle territorial nas favelas. Baseava suas críticas no número elevado de mortes provocadas nessas ocasiões e no fato de essas operações não terem conseguido acabar com o domínio das facções criminosas. Por fim, o relatório recomendava que fossem realizadas reformas na polícia e nos órgãos do governo relacionados ao tema da violência, como os do Poder Judiciário (ONU, 2008).

O Pronasci contava com um orçamento de pelo menos um bilhão anual, reservado até 2012, para ser repassado pelo governo federal para estados e municípios. Por meio da criação de Gabinetes de Gestão Integrada de Segurança Pública (GGIS), entre as três instâncias de governo, eram selecionados diversos programas que seriam implementados (ALVES; EVANSON, p. 207).

Alguns programas eram voltados para policiais, oferecendo uma série de benefícios. $O$ Bolsa Formação, por exemplo, nessa época, oferecia a possibilidade de ampliar a capacitação desses profissionais por meio da complementação do salário para a realização de cursos. Outro programa oferecia empréstimos a juros baixos para a compra da casa própria. Havia, ainda, previsão de verbas para a construção de ginásios para os policiais e para a guarda municipal, assim como para a melhoria de serviços de assistência à saúde. 
Já outros programas eram voltados às comunidades, como o Mulheres da Paz, que capacita lideranças femininas para agirem como mediadoras sociais na prevenção e no enfrentamento de todo tipo de violência que envolva jovens e mulheres. Outro exemplo é o Projeto para Proteção de Jovens em Territórios Vulneráveis (Protejo), treinamentos para jovens entre 16 e 29 anos, em trabalhos comunitários e recreação (ALVES; EVANSON, 2013, p. 208).

No rastro desse processo de revisão da política de segurança pública no Rio de Janeiro, a ideia do policiamento comunitário contava com o apoio do então ministro da justiça Tarso Genro, "crítico declarado da política de confronto" (ALVES; EVANSON, 2013, p. 209). O Pronasci oferecia, como parte do programa de treinamento dos policiais, o policiamento comunitário, mas, como explicou Beltrame, em entrevista,

\begin{abstract}
é requisito fundamental para o policiamento comunitário que ele esteja em uma região que esteja [...] pacificada. Ou seja, que não tenha atuação criminosa nenhuma, nem milícia, nem tráfico, nem nada, por que aí [...] a polícia comunitária pode fazer o seu fundamento [...] a troca [de informações entre moradores e policiais]. (ALVES; EVANSON, 2013, p. 228).
\end{abstract}

Desse modo, em 12 de novembro de 2008, o jornal O Globo, um dos principais periódicos do Rio de Janeiro, trazia, em primeira mão, a notícia PM ocupa Cidade de Deus e 7.700 ficam sem aulas e, oito dias depois, publicava a manchete Polícia ocupa o Morro Dona Marta. O programa das Unidades de Polícia Pacificadora (UPPs) começava a ser implantado, embora sem fazer referência a uma nova política de segurança pública, já mostrava uma novidade. A polícia havia chegado para ficar, ou seja, iria permanecer nos locais ocupados, sem prazo para se retirar.

\title{
2.5 UNIDADES DE POLÍCIA PACIFICADORA (UPPS)
}

O programa das UPPs é um modelo de segurança pública e policiamento, implantado pela Secretaria de Segurança do Rio de Janeiro, no fim de 2008, com o objetivo de promover "a retomada (territorial) permanente (por parte do Estado) de comunidades dominadas pelo tráfico, assim como a garantia da proximidade do Estado com a população" (RIO DE JANEIRO (Estado), [2008?]).

Dessa forma, o programa visa a oferecer aos moradores dessas áreas o acesso a um direito básico: "a segurança de que não terão o seu cotidiano invadido pela presença da morte súbita; pela violência contra suas casas e pelo poder autoritário de um criminoso" (SILVA $^{a}, 2012$, p. 426). Almeja, ainda, ampliar as possibilidades de desenvolvimento social e econômico, por meio da garantia da "entrada de serviços públicos, infraestrutura, projetos sociais, esportivos e culturais, investimentos privados e oportunidades" (RIO DE JANEIRO 
(Estado), [200?]). Dessa forma, o Estado espera abrir um leque de novas oportunidades nas relações desses territórios com a cidade.

Coordenado pela Subsecretaria de Planejamento e Integração Operacional, vinculada à Secretaria de Estado de Segurança do Rio de Janeiro, o programa conta com parceria dos governos municipal e federal e com a sociedade civil organizada. Na página oficial do programa, ele é apresentado como um dos mais importantes programas de Segurança Pública realizados no Brasil nas últimas décadas. Os princípios que orientam seu modo operacional são os de polícia de proximidade, "um conceito que vai além da política comunitária e tem sua estratégia fundamentada na parceria entre a população e as instituições da área de Segurança Pública" (RIO DE JANEIROa).

Em relação às políticas anteriores de segurança pública do Estado do Rio de Janeiro, pode-se dizer que as UPPs têm suas raízes nas ideias sobre policiamento comunitário do Coronel Cerqueira. Dessa forma, as UPPs podem ser vista como uma evolução de experiências anteriores de policiamento comunitário em favelas, que se inspiraram nessas ideias, como, por exemplo, o GAPE e o GAEP. No entanto, essas experiências foram implantadas de forma pontual e independente e não como um novo paradigma adotado pela política de segurança pública. É nesse aspecto que as UPPs se diferenciam dessas experiências anteriores, tratando-se "de um projeto que dá centralidade à polícia comunitária e ao tratamento da segurança como uma política pública. Além disso, é um projeto que reivindica um enfoque interdisciplinar (que busca a integração de outras políticas de acesso à cidadania) e de cooperação entre os diversos níveis federativos, criando, por exemplo, a UPP-Social" (OLIVEIRA; ABRAMOVAY, 2012, p. 126).

A primeira UPP foi instalada na favela Santa Marta, no Morro Dona Marta. A favela está localizada na Zona Sul da cidade, incrustada em Botafogo, um bairro de classe média repleto de escolas privadas, inclusive três escolas internacionais (Figura 3). Possui uma população de cerca de cinco mil habitantes e casinhas coloridas, que parecem desafiar qualquer teoria da construção civil. As cores fazem parte de um programa de revitalização da favela que se deu logo após a implantação da UPP.

A comunidade ganhou projeção internacional depois que serviu, em 1996, de locação para a gravação do videoclipe do cantor Michael Jackson, para a música They don't care about us. Na época, a mídia enfatizou ainda, em tom de escândalo "o fato de a equipe de produção ter solicitado - e conseguido - a autorização do então chefe do tráfico local, Marcinho VP, para realizar o trabalho" (SILVA, 2012, p. 424).

Marcinho VP, conhecido como uma espécie de Robin Hood local, por suas preocupações sociais com a comunidade, parece ter sempre sido uma pessoa bem 
relacionada. Ajudou o cineasta João Moreira Salles a fazer o documentário Notícias de uma guerra particular, com importantes informações, e teve sua biografia assinada pelo jornalista Caco Barcellos, autor do livro Abusado - O dono do Morro Dona Marta.

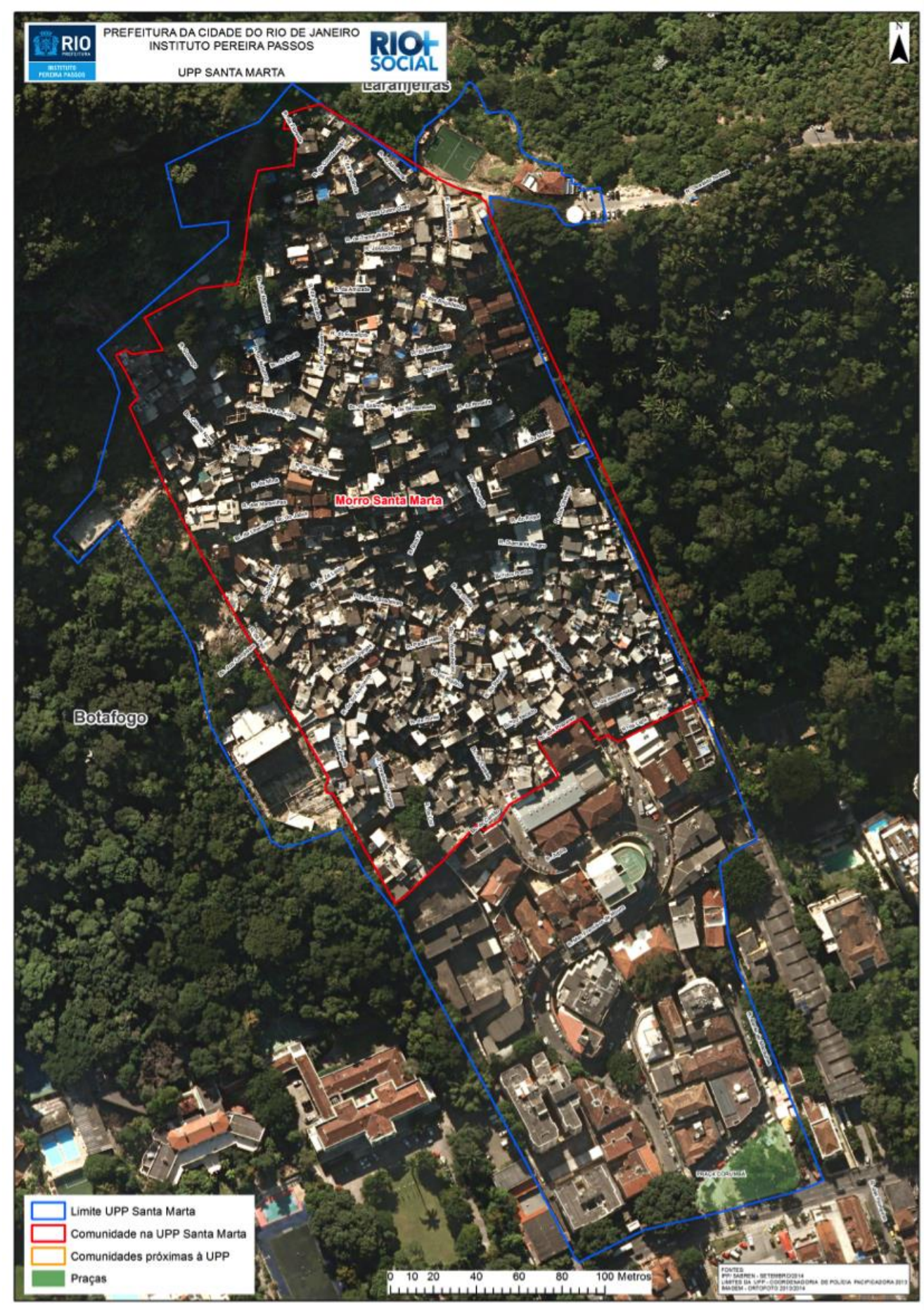

Figura 3 - Vista aérea dos limites da UPP da favela Santa Marta.

Fonte: <http://www.riomaissocial.org/territorios/santa-marta/?secao=mapas>.

A partir da Santa Marta, em 2009, as UPPs expandiram-se rapidamente para outras favelas da Zona Sul (Chapéu Mangueira; Babilônia; Cantagalo; Pavão e Pavãozinho). 
Além dessas, naquele ano, somente duas favelas receberam unidades do programa fora dos limites da Zona Sul, ambas localizadas na Zona Oeste da cidade: a do Batan - em Realengo - e a Cidade de Deus - em Jacarepaguá. Essa última, atualmente é considerada um bairro. Como explicam Alves e Evanson (2013, p. 424), a favela do Batan foi incluída nessa primeira fase do programa por causa da tortura sofrida por uma equipe de jornalistas do jornal O Dia, em 2008; já a segunda comunidade, "aparentemente, em função do impacto do filme Cidade de Deus", lançado no Brasil em 2002.

Em 2010, o programa de pacificação foi implantado em mais duas comunidades da Zona Sul, Tabajaras e Cabritos, e chegou à Zona Norte da cidade (Providência, Borel, Formiga, Andaraí, Salgueiro, Turano e Macacos). Em fevereiro de 2014, com a inauguração da UPP Mangueirinha, o programa extrapolou a capital do estado, chegando à Baixada Fluminense (Figura 4).

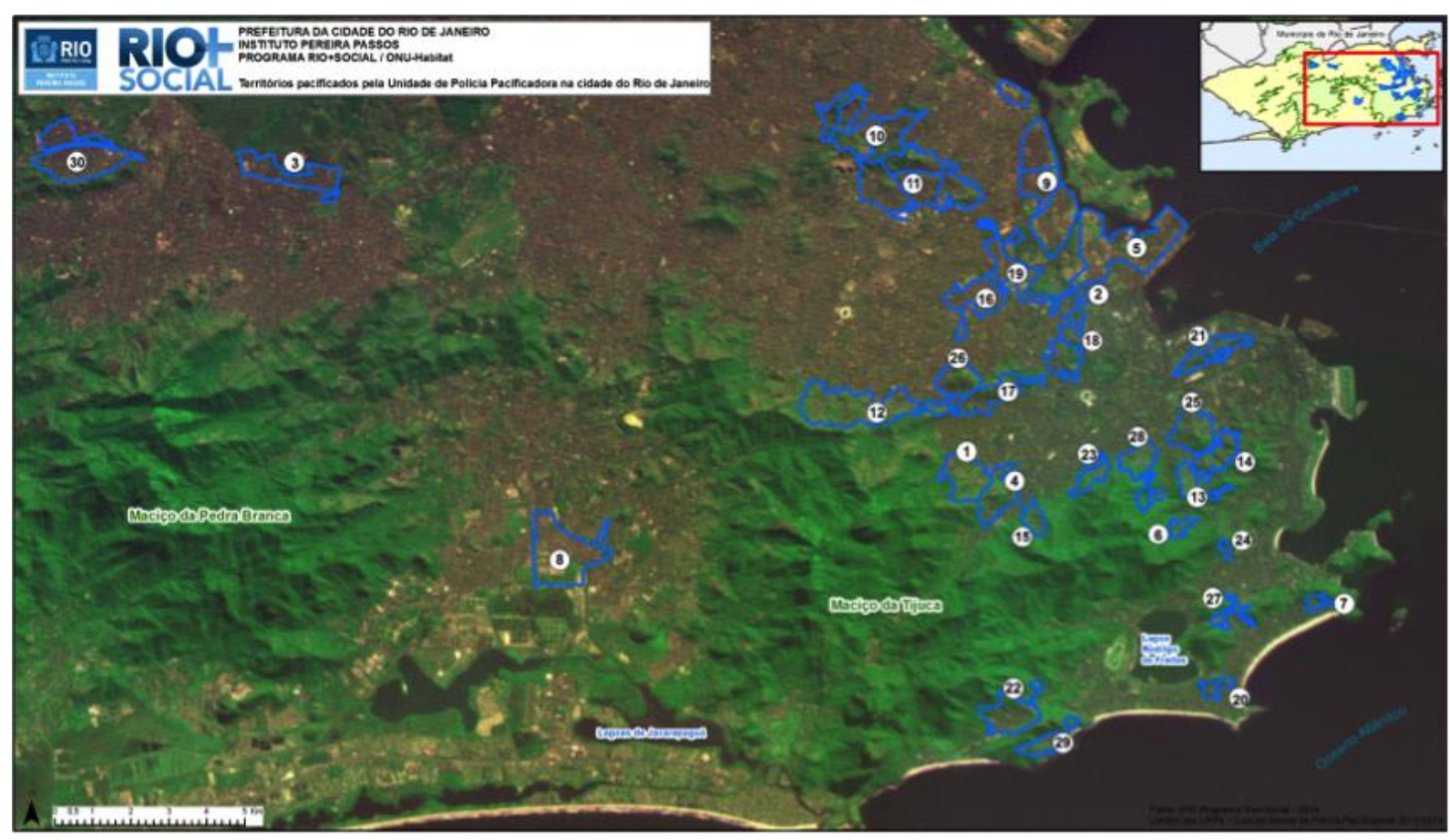

Figura 4 - Mapa com as delimitações das UPPs.

Fonte: <http://www.riomaissocial.org/territorios/santa-marta/?secao=mapas $>$.

Até 2014, já haviam sido instaladas 38 UPPs, no Estado do Rio de Janeiro, distribuídas em 50 favelas e complexos. Como alguns desses complexos reúnem várias favelas, o número total de favelas atendidas pelo programa é ainda maior. Esse mesmo site oficial do programa informa que a previsão era de que seriam instaladas mais 40 unidades, sem informar em que período. Essa meta, até 2005, não havia sido alcançada, pois nenhuma nova UPP foi instalada. O programa conta com um efetivo de 9.543 policiais. A previsão é que esse efetivo cresça, chegando a 12,5 mil policiais (RIO DE JANEIRO (Estado), [200?]). 
Em relação aos resultados da implantação das UPPs, uma pesquisa realizada pelo Fórum Brasileiro de Segurança Pública, em cooperação com o Laboratório de Análise da Violência da UERJ, mostra que o programa atingiu seus dois grandes objetivos: "a recuperação do controle territorial de áreas que estavam sob o domínio de grupos criminosos armados, e o fim dos confrontos armados" (CANO, 2012, p. 175). No entanto, salienta que o tráfico continua presente nas comunidades, mas isso não invalida o novo programa de segurança pública, já que o fim da comercialização de drogas não era uma meta contemplada. Hoje, o tráfico mudou sua forma de atuação, já que não é mais um poder onipresente nesses locais.

Uma redução significativa da violência letal é outro dado importante levantado por essa pesquisa. "Em média, a instalação de uma UPP poupa meia vida a cada mês em cada uma das comunidades" (CANO, 2012, p. 178). Entre os indicadores usados para medir a violência nessas áreas, o que sofreu a maior queda foi o utilizado para medir o número de mortos em intervenções policiais, os chamados Autos de Resistência. Depois da entrada das UPPs nesses locais, a pesquisa mostrou que eles alcançaram um nível próximo de zero.

Balanço com os principais indicadores da política de pacificação, desde 2007 (ano anterior ao do início da política) até o final de 2014, realizado pelo Instituto de Segurança Pública (ISP), comprova a efetividade dessa política implementada pelo governo do Estado. Como pode ser observada na Figura 5, a "taxa de homicídio doloso em áreas de UPP foi de 7,4 mortes por 100 mil habitantes (40 vítimas) em 2014, número que é um terço da taxa verificada em 2008, ano em que a primeira comunidade foi ocupada" (COELHO, CONCEIÇÃO; PROVENZA, 2015, p. 3). 


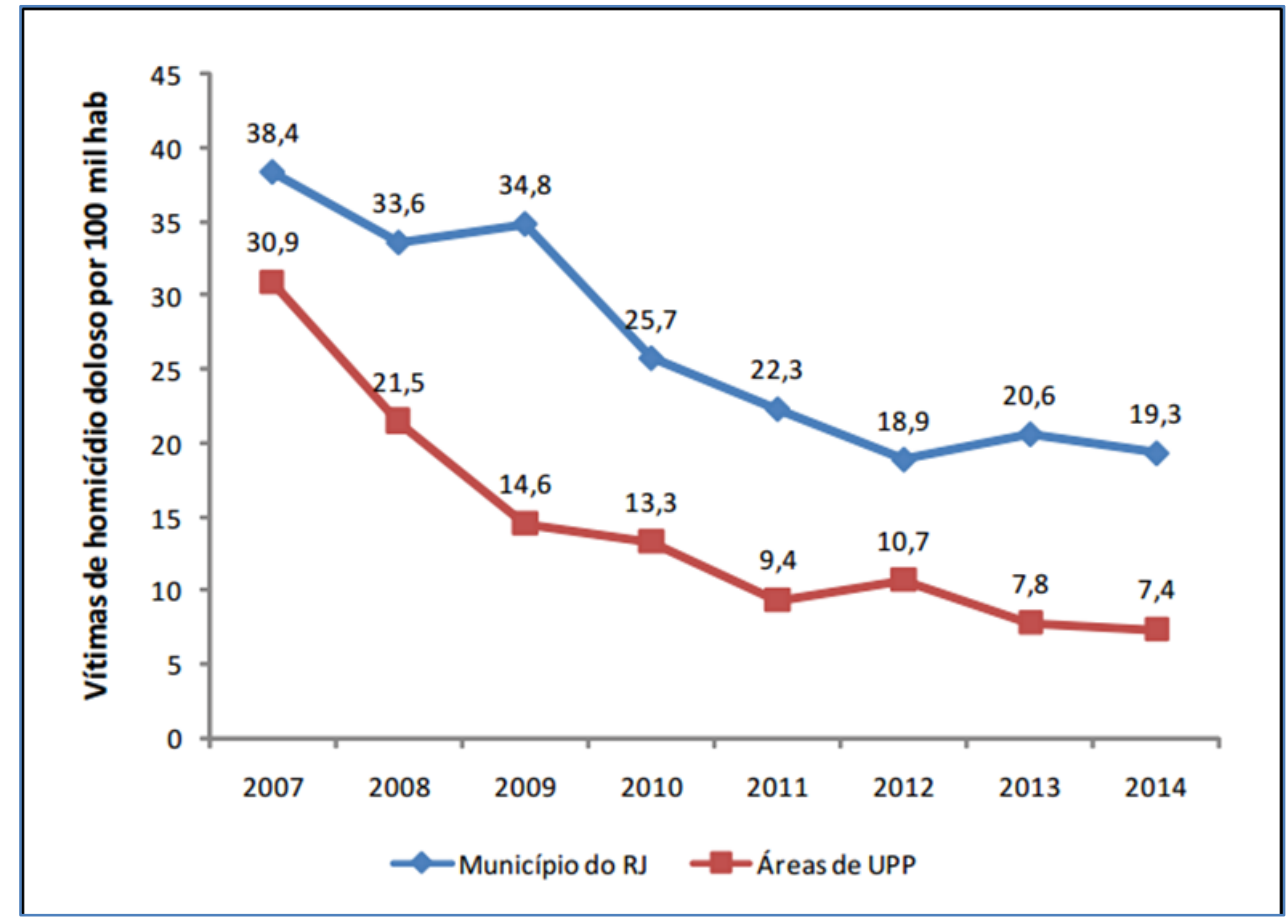

Figura 5 - Taxas de homicídio doloso no estado e na cidade do Rio de Janeiro (série histórica).

Fonte: COELHO et al, 2015.

O documento mostra, ainda, que a redução dos homicídios decorrentes de intervenção policial foi ainda maior (85\% no período). Em 2014, foram registradas 20 mortes devido à intervenção policial em áreas de UPP, enquanto, em 2008, esse registro foi de 136 vítimas (Figura 6).

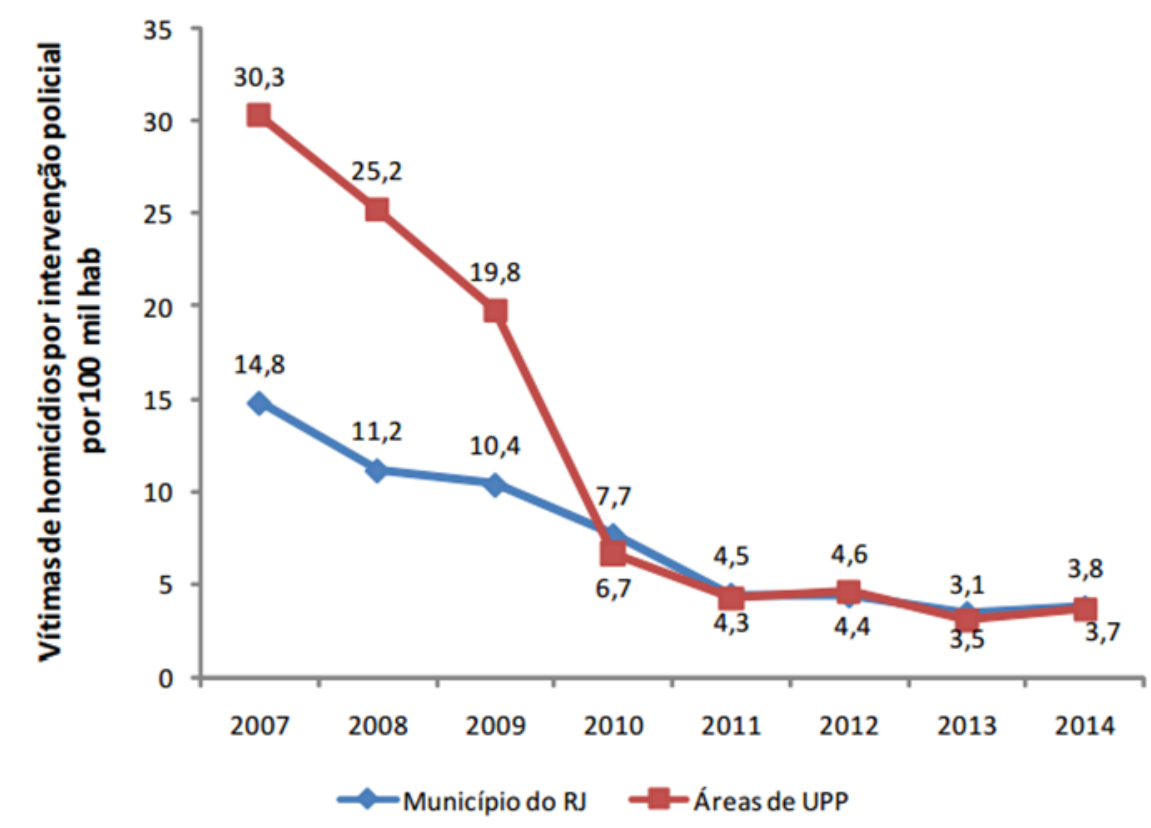


Figura 6 - Vítimas de homicídios por intervenção policial no município do Rio de Janeiro e em áreas de UPP.

Fonte: COELHO et at, 2015.

A diminuição dessas duas taxas nas áreas pacificadas, taxas de homicídio doloso e de homicídio por intervenção militar, reforça a ideia de que é possível diminuir a violência nessas áreas com uma ação policial diferenciada. Embora saibamos que mesmo tendo diminuído, as histórias de violência ainda existem. Um exemplo da violência policial, muito divulgado pela imprensa, foi o caso do desaparecimento do pedreiro Amarildo, detido em julho de 2013 por policiais militares na Rocinha. Após a apuração de denúncias de que Amarildo teria sido levado à força para a UPP da favela e sido torturado, 12 dos 25 PMs acusados foram condenados pela justiça no início de 2016. Em maio de 2015, foi a vez de a favela Santa Marta ocupar o noticiário por causa de um incidente violento. Naquele mês, a favela, considerada modelo da nova política de segurança pública, enfrentou o primeiro registro de tiroteio, depois que criminosos dispararam contra policiais.

Em menor medida, os roubos também diminuíram. Embora houvesse um maior número de registros de crimes não letais contra a pessoa e de crimes não violentos contra a propriedade, as explicações apontam tanto para uma maior mobilização das pessoas para denunciar, seja porque passaram a ter menos medo, seja porque passaram a ser orientadas para isso, como também para uma ausência do controle autoritário outrora exercido pelo dono do morro. A pesquisa do Fórum Brasileiro de Segurança Pública com a UERJ mostra, ainda, que o impacto positivo na criminalidade, após a implantação das UPPs, estendeu-se para o entorno dessas comunidades, em um raio de até 1.500 metros (CANO, 2012, p. 179).

Outra consequência importante da implantação das UPPs foi a chegada de novos investimentos e a criação de novas oportunidades econômicas para essas comunidades. O processo de pacificação tem trazido a reboque maior participação dos setores público e privado, seja em investimentos em obras de infraestrutura, na ampliação e na melhoria do acesso aos serviços públicos ou na oferta de formação profissional por meio do Sistema $\mathrm{S}$ e de empregos. "O setor privado entra (...) com uma contribuição direta ao financiamento do programa, fato novo nas políticas de segurança do Rio, e também com iniciativas locais, como a oferta de empregos" (CANO, 2012, p. 177).

As favelas pacificadas têm recebido investimentos públicos como o Programa de Aceleração do Crescimento (PAC), do governo federal, que realizou obras de infraestrutura na Rocinha, Alemão, Manguinhos e Pavão-Pavãozinho. O atual governador Luiz Fernando 
Pezão anunciou, assim que assumiu o governo em 2015 que a segunda fase do PAC investirá nas favelas pacificadas $\mathrm{R} \$ 2,6$ bilhões. A prefeitura do Rio de Janeiro, por meio do Instituto Pereira Passos (IPP), investiu, desde 2009 até 2014, R $\$ 1,8$ bilhão em urbanização, saúde, educação, serviços e eliminação de áreas de risco, por meio do Rio+ Social.

Já o governo do Estado tem procurado fomentar o crédito ao empreendedor. Para isso, lançou o Fundo UPP Empreendedor, que permite financiamentos entre $R \$ 300$ e $R \$ 15$ mil a juros baixos ( $3 \%$ ao ano) e prazo de pagamento de até 24 meses, com até três meses de carência. O fundo é administrado pela agência de fomento AgeRio, vinculada à Secretaria Estadual de Desenvolvimento Econômico, Energia, Indústria e Serviços (Sedeis). Com uma estratégia especialmente pensada para as favelas pacificadas, a AgeRio atua com profissionais que moram nas próprias áreas pacificadas. Eles divulgam o programa de financiamento, prospectam novos empreendedores e os ajudam a montar um plano de negócios, mas só pode se candidatar a receber o benefício quem não tem problemas de cadastro. Até o início de outubro de 2014 mais de 5 mil contratos de microcrédito já haviam sido assinados com a AgeRio, somando $\mathrm{R} \$ 21,8$ milhões em operações. Nessa época, a Agência chegou a divulgar que sua meta oficial era apoiar 20 mil empreendedores até 2018. No entanto, em 2015, a concessão de microcréditos foi suspensa e até junho de 2016 a informação oficial divulgada no site da Agência era que o programa estaria passando por reformulação.

Empresas privadas também têm aumentando sua presença nas favelas. Uma das lojas de eletrodomésticos mais conhecidas do Brasil, a Casas Bahia, por exemplo, abriu uma filial na Rocinha, em 2012, onde "mantém performance de vendas por cliente acima da média das outras lojas de bairro" (NAS COMUNIDADES..., 2014, p. 39). Em 2014, a loja abriu outra filial no Complexo do Alemão, contratando mão de obra local inclusive para a vaga de gerente.

O capital privado tem chegado às favelas pacificadas, também, por meio da atuação do Sebrae-RJ, que criou, em 2011, o Programa de Desenvolvimento de Empreendedorismo em Comunidades Pacificadas do Rio de Janeiro. "Esse programa já atendeu mais de 52 mil pessoas e colaborou para a formalização de mais de 5 mil empreendimentos. Capacitou 6.500 pessoas em mais de 700 atividades, oferecendo cursos, palestras, oficinas e seminários, e desenvolveu metodologia especial para apoio ao empreendedorismo em áreas de baixo Índice de Desenvolvimento Humano (IDH), utilizado pela Organização das Nações Unidas para medir o progresso pelas dimensões da renda, educação e saúde" ( NAS COMUNIDADES...., 2014, p.40) . 
No entanto, a pesquisa realizada pelo Fórum Brasileiro de Segurança Pública com a UERJ mostra que os investimentos sociais e econômicos nas comunidades não foram homogêneos. Em algumas, foram expressivos, em outras, quase não ocorreram. O mesmo é observado em relação ao impacto econômico da nova política de segurança pública.

A ampliação da formalização das atividades econômicas e dos serviços oferecidos pelo Estado e pela iniciativa privada, como o fornecimento de energia elétrica e TV a cabo, antes utilizados de forma irregular, é outra mudança observada nas comunidades que receberam as UPPs. A pesquisa ressalta, entretanto, que a transição da informalidade para a formalidade traz vantagens e desvantagens para os moradores. "Se, por um lado [...] os usuários [...] podem desfrutar do status de cliente, por outro tende a incrementar os custos dos serviços e das atividades econômicas, em suma, o custo de morar nestas comunidades" (CANO, 2012, p. 177).

O aumento resultante dos preços dos aluguéis e dos imóveis também é assinalado. Como resultado houve expulsão dos moradores, processo denominado de gentrificação, que foi verificado em nossas visitas ao Morro da Babilônia, no bairro do Leme. O conceito refere-se a mudanças na paisagem urbana, ocasionada pela "ocupação por classe de maior poder aquisitivo de uma área previamente ocupada por classes mais pobres, num processo de valorização econômica da área e transformações físicas e sociais" (BRUM, 2013, p. 197).

A pesquisa mostra, ainda, que o processo de pacificação tem trazido mudança no "clima" dessas comunidades, outrora marcado pelo controle autoritário do tráfico. Agora, existe "maior liberdade de ir e vir" dos moradores, assim como maior liberdade de "as pessoas [...] expressar[em] sua opinião, mesmo quando é crítica em relação ao projeto" (CANO, 2012, p. 179-180).

A atenuação do estigma social em torno das favelas, alcançada com a implantação das UPPs, e a consequente maior integração dessas comunidades com a cidade, constituem aspectos positivos do processo de pacificação ressaltados pela pesquisa. Isso pode ser sentido "numa entrada do resto da cidade nessas comunidades e no fato de que os seus moradores não precisam mais esconder o seu local de moradia quando procuram emprego" (CANO, 2012, p. 181).

O novo programa de segurança pública representado pelas UPPs é mais uma tentativa do Estado para combater a violência nas favelas, usando a estratégia do policiamento comunitário. Diferente das outras experiências anteriores, como o GAPE e o GAEP, o programa é implantado não de forma experimental ou pontual, mas com o aporte institucional de uma política estadual de segurança pública que conta com a parceria do governo federal e Municipal. Além disso, ao considerar que a redução da violência envolve 
outros aspectos que extrapolam a questão da segurança pública, o programa tem buscado a participação da iniciativa privada e, como veremos adiante, a integração com outras políticas públicas de promoção da cidadania.

A parceria entre as três esferas do governo foi facilitada pelo momento político propício desde que o programa das UPPs começou em 2008. O presidente da República, Lula, filiado ao PT, apoiou a eleição de Sérgio Cabral, do PMDB, para o governo do estado do Rio de Janeiro em 2006. Dois anos mais tarde, Eduardo Paes recebe apoio de Cabral e de Lula e ganha as eleições para prefeito da cidade do Rio de Janeiro pela chapa do PMDB. Consideramos que essa coligação partidária, mantida até 2016, certamente contribuiu para a continuidade da nova política de segurança pública no Estado do Rio de Janeiro. A partir de 2016, com o rompimento da aliança política entre PT e PMDB e o impeachment da presidente Dilma, a parceria entre as três esferas do governo pode ser afetada, ficando difícil prever como isso irá impactar a continuidade da nova política de segurança pública.

Em termos de resultado, embora as UPPs não tenham conseguido eliminar completamente a presença do tráfico nas favelas, as taxas de violência nesses locais foram reduzidas. Entre os indicadores utilizados para medir essa mudança, destaca-se a queda das taxas de homicídio por intervenção policial, mostrando haver uma mudança em curso na ação da polícia. Na próxima seção, veremos como essa mudança está sendo percebida por lideranças e empreendedores nas comunidades estudadas.

\subsection{PERCEPÇÃO DOS MORADORES EM RELAÇÃO ÀS UPPS}

A circulação de moradores do asfalto e turistas, inclusive estrangeiros, observada nas comunidades Chapéu Mangueira e no Morro da Babilônia, assim como os depoimentos colhidos em campo para esta pesquisa, na Favela Santa Marta, confirmam essa percepção. A costureira Marizete, que mora em uma das vias de acesso dessa favela, por exemplo, destacou: "Uma coisa que a pacificação ajudou muito foi quebrar o preconceito que havia com a favela. Hoje se paga caro para passar uma noite na favela e ir às festas. Só filho de bacana" (Marizete, Favela Santa Marta).

O maior movimento de pessoas de fora da comunidade tem beneficiado não apenas a realização de festas, mas a comercialização de outros produtos feitos na favela como os artesanatos e, ainda, a venda de pacotes turísticos, especialmente criados para mostrar o local a quem é de fora. Na opinião da costureira Sonia, companheira de Marizete no Grupo Costurando Ideais: 
A pacificação melhorou muito o nosso trabalho, porque hoje as pessoas vêm sozinhas ao morro, não precisam mais ligar para avisar que estão vindo. Não teríamos a visibilidade que tivemos para o nosso trabalho se não fosse pacificado (Sonia, costureira do grupo Costurando Ideais, da Favela Santa Marta).

No entanto, a continuidade dessa política é apontada pelos moradores como um desafio constante. Como demostra a pesquisa realizada pelo Fórum de Segurança Pública, embora eles valorizem "o projeto pelo fim dos tiroteios e do domínio do tráfico, bem como pela maior liberdade de ir e vir, [...] muitos temem a descontinuidade da iniciativa e, com ela, as represálias contra aqueles que se aproximaram da polícia" (CANO, 2012, p. 180).

Para evitar que isso aconteça é preciso, depois da instalação da UPP, que a polícia não esmoreça sua presença na comunidade. Foi isso que Sonia sublinhou, ao lembrar do tiroteio que assustou os moradores em maio de 2015, depois de sete anos de paz (dezembro de 2008-maio de 2015).

Na descida do morro, após ter terminado nossa entrevista, Sonia acrescentou: "É preciso cuidar, estar atento sempre. Este ano houve uma tentativa de retomada do tráfico. Sabe por quê? Porque a polícia da UPP deu mole". Corajosa, Sonia, uma liderança respeitada no morro, não perdeu a oportunidade de dizer isso tête-à-tête ao comandante da unidade em uma reunião da polícia com os moradores. Sua colega Marizete contou que, quando ouviu, quase morreu de susto e até tentou impedir que a colega prosseguisse com as críticas, mas não adiantou. Sonia havia acabado de aceitar a encomenda do vestido de noiva para o casamento do Comandante, mas não se intimidou em ter a encomenda cancelada. Disse tudo o que pensava diretamente. Percebe-se com essa atitude, que a instalação do policiamento comunitário na comunidade tem possibilitado o fortalecimento dos laços sociais entre moradores e PM, promovendo, dessa forma, o diálogo e a aproximação entre a sociedade e o Estado.

A melhoria da qualidade de vida é outro desafio levantado pelos moradores das comunidades que receberam UPPs, como mostram as entrevistas da pesquisa realizada pelo Fórum Brasileiro de Segurança Pública com a Uerj a respeito do impacto dessa nova política de segurança pública. Embora os projetos sociais e as oportunidades econômicas trazidas com a pacificação aparecessem "em segundo plano" no rol das expectativas das pessoas, a pesquisa aponta que, certamente, terão um papel importante na avaliação final do programa. No entanto, essa mesma pesquisa mostra que tais melhorias parecem "em curso de acontecer apenas em alguns locais, mas não em outros" (CANO, 2012, p. 180).

Vimos até aqui que a implantação das UPPs tem produzido resultados positivos. Entre eles, podemos destacar a diminuição da violência nas favelas pacificadas e a consequente redução do estigma social em relação a esses locais. Com isso, houve uma maior liberdade 
de ir e vir tanto dos moradores, como de pessoas de fora interessadas em visitar ou frequentar as favelas. Além disso, a pacificação tem servido como fator de atração para novos investimentos e de incentivo para a criação de novas oportunidades de negócios.

Todavia, vimos, também, que para o programa se consolidar deve enfrentar dois grandes desafios. O primeiro é a garantia de sua continuidade mesmo após o fim dos Jogos Olímpicos em 2016. O segundo é a expansão do programa das UPPs para além do controle territorial por parte do Estado e o fim dos conflitos armados. A mudança da qualidade de vida dos moradores, que pode ocorrer com a entrada de novos investimentos públicos e privados, deve oferecer alternativas econômicas diferentes daquelas oferecidas pela economia do tráfico para se manter. Como veremos na próxima seção, será a presença consolidada do Estado nessas áreas, combinada com a abertura de novas oportunidades de negócios, que pode contribuir para o combate à exclusão social e a garantia dos direitos civis.

\subsection{UM FRÁGIL NOVO COMEÇO EM CURSO}

McCann (2014) ao fazer uma análise histórica do que aconteceu nas favelas do Rio de Janeiro, desde a década de 1970, reconhece "um frágil novo começo em curso" no Rio de Janeiro. Com essas palavras, o autor descreve a impressão que teve da cidade ao retornar a ela, entre 2010 e 2013, para a realização de seu livro Hard times in the Marvelous City.

Em 2004 e 2006, quando ele, ainda, estruturava o campo de sua pesquisa para a elaboração desse livro, a imagem que tinha sobre a cidade era desanimadora. A explicação encontrada para essa percepção seria os modelos cíclicos de violência que marcaram as políticas de segurança pública adotadas para a cidade até então, assim como a expansão constante do tráfico de drogas.

No entanto, na segunda fase de sua pesquisa (entre os anos de 2010 e 2013), McCann pode perceber que "os sonhos de extensão total e completa da cidadania para os residentes das favelas do Rio não morreram" (McCann, 2014, p. 17, tradução nossa). O gap que havia entre os depoimentos gravados e o que era dito em off diminuiu, mostrando que os entrevistados estavam muito mais dispostos a falar no gravador sobre a realidade das favelas. Um "aliviado e maravilhado senso de esperança" (McCann, 2014, p. 182, tradução nossa) passou a ser percebido nas entrevistas que ele realizou em seu trabalho de campo.

$\mathrm{Na}$ Cidade de Deus, por exemplo, o autor observou sinais de maior dinamismo econômico. Notou, também, que a diversificação das organizações da sociedade civil no 
local alterou a relação dessas organizações com a corrupção e o tráfico. Zaluar (2006) já havia denunciado o envolvimento, durante os anos 1980, das associações e organizações populares com a prática da corrupção, assim como a pressão exercida pelos traficantes para ter seus representantes eleitos nesses movimentos. Entre os anos de 2010 e 2013, McCann (2014) percebeu que esses problemas, embora não tenham sido eliminados, foram reduzidos. Outro aspecto positivo ressaltado por McCann (2014) foi a maior presença do Estado, promovendo "um ambiente urbano caracterizado por grandes oportunidades e recursos" (McCann, 2014, p. 186, tradução nossa).

Toda essa mudança nas favelas cariocas, McCann atribui ao recente crescimento econômico do país e ao novo momento vivido pelo Rio de Janeiro, quando, pela primeira vez em décadas, foi registrado um aumento formal de empregos. Entre as contribuições para esse florescimento econômico do Rio, o autor destaca a promissora produção offshore de petróleo e os investimentos para a realização dos megaeventos esportivos (Copa do Mundo, em 2014, e os Jogos Olímpicos, em 2016). Porém, diferente de outros períodos de crescimento, como o promovido pelo milagre econômico brasileiro, no início dos anos 1970, no qual as desigualdades sociais foram exacerbadas, o autor diz que "os moradores de favela têm usufruído de alguns dos benefícios do corrente boom" (McCann, 2014, p. 187, tradução nossa).

O aumento formal de empregos a que McCann (2014) se refere pode ser conferido na Tabela 2. Em relação a 2003, as estimativas de 2012 mostram que houve um crescimento de $38,4 \%$ (de 1,7 para 2,4 milhões) no contingente de empregados com carteira assinada no setor privado na cidade do Rio de Janeiro. Esse aumento não ocorreu apenas neste estado. No país, o crescimento no contingente de empregados com carteira assinada no setor privado foi de $53,4 \%$ (de 7,3 para 11,3 milhões). Em outros estados, esse aumento foi até maior do que o do Rio de Janeiro. Na Região Metropolitana de Recife, por exemplo, ele foi de 80,4\%; em Salvador, 73,1\%, em Belo Horizonte, 67,7\%, São Paulo, 54,3\% e Porto Alegre, $43,6 \%$. 
Tabela 2 - número de empregados com carteira de trabalho assinada no setor privado, por regiões metropolitanas (em 1.000 pessoas).

\begin{tabular}{|lrrrrrrr|}
\hline & \multicolumn{1}{l}{ Total } & \multicolumn{1}{l}{ Recife } & Salvador & $\begin{array}{c}\text { Belo } \\
\text { Horizonte }\end{array}$ & $\begin{array}{c}\text { Rio de } \\
\text { Janeiro }\end{array}$ & São Paulo & \multicolumn{2}{c|}{$\begin{array}{c}\text { Porto } \\
\text { Alegre }\end{array}$} \\
\hline 2003 & 7349 & 393 & 480 & 759 & 1745 & 3301 & 671 \\
2004 & 7475 & 405 & 489 & 793 & 1761 & 3337 & 690 \\
2005 & 7866 & 438 & 511 & 850 & 1792 & 3542 & 734 \\
2006 & 8240 & 446 & 534 & 910 & 1884 & 3726 & 740 \\
2007 & 8663 & 485 & 580 & 969 & 1968 & 3896 & 765 \\
2008 & 9303 & 516 & 618 & 1053 & 2018 & 4267 & 831 \\
2009 & 9509 & 552 & 656 & 1090 & 2054 & 4311 & 846 \\
2010 & 10191 & 618 & 713 & 1162 & 2206 & 4596 & 897 \\
2011 & 10888 & 675 & 785 & 1232 & 2345 & 4899 & 952 \\
2012 & 11287 & 709 & 831 & 1273 & 2416 & 5095 & 964 \\
\hline
\end{tabular}

Fonte: IBGE, Pesquisa Mensal de Emprego: evolução do emprego com carteira de trabalho assinada 2003-2012

A implementação da nova política de segurança nas favelas, representada pela instalação das UPPs, é destacada pelo autor como a mais surpreendentemente parte desse novo momento vivido pelo Rio de Janeiro. McCann (2014) afirma que a atual política de segurança pública retoma as propostas feitas em meados de 1980, pelo Secretário da Polícia Militar de Brizola, Coronel Nazareth Cerqueira, com a diferença de que o governo acreditou e deu muito mais condições de essas propostas saírem do papel com as UPPs. Isso é visível, pelo maior aporte de investimentos e comprometimento que receberam. Ao comparar as duas políticas, o autor aponta como possíveis causas do fracasso das medidas implementadas por Cerqueira a falta de apoio da própria corporação, a falta de recursos e a magnitude das redes criminosas.

Embora considere a atual política de segurança pública uma esperança para o Rio, McCann (2014) ressalta que o futuro dela é incerto. Afinal, não é fácil mudar uma tradição de policiamento violento. Contudo, como assinala o Fórum Brasileiro de Segurança Pública (FBSP)

as UPPs são, para além de seu impacto local, uma grande oportunidade para reformar as políticas de segurança pública e a Polícia Militar do Estado do Rio de Janeiro e para explorar novas formas de regulação social legal e democrática nas favelas que substituam o velho controle autoritário exercido tanto pelos criminosos como pelo próprio Estado (FBSP, 2012, p. 184).

Em sua avaliação sobre as UPPs, McCann (2014) reconhece que, no período de cinco anos analisado, o programa alcançou resultados positivos e que a vida na favela mudou radicalmente. A diminuição da violência dentro e em volta das favelas pacificadas é perceptível, embora o autor lembre que as redes criminosas não tenham desaparecido por completo. 
Outras mudanças observadas por McCann (2014) reforçam a hipótese apresentada nessa pesquisa de que o fim do domínio dos espaços públicos pelo tráfico amplia as possibilidades de convivência entre as pessoas e, a partir daí, as condições para o surgimento de um ambiente mais fértil para o florescimento de novas ideias. McCann (2014) observou que estão aparecendo novos negócios nessas comunidades e que "o momento atual oferece a oportunidade, pela primeira vez em 30 anos, de afirmar uma diferença positiva enquanto combate à exclusão a partir do reconhecimento do Estado de Direito e das garantias dos direitos civis" (McCann, 2014, p. 192, tradução nossa).

No entanto, o autor destaca que é cedo para saber se esses ganhos iniciais irão ser mantidos. À medida que o programa se expande, certamente aumentarão, também, seus desafios. Assim como sugerem outras pesquisas, como o relatório do Banco Mundial (2013), McCann acredita que a sustentabilidade dessa nova política de segurança pública vai depender muito da história local de violência onde está sendo implantada, assim como da "delicada relação entre residentes e a polícia" (McCann, 2014, p. 191, tradução nossa).

O grande risco das UPPs, a seu ver, é que, em vez de se firmar como uma nova estratégia de atuação da polícia, ela se transforme "em um modo de controle das favelas, reforçando a separação destas em relação à cidade formal". (McCann, 2014, p. 192, tradução nossa).

É possível perceber que o enfrentamento dessa questão da violência nas favelas e comunidades populares no Rio não é tarefa para ser concluída em um par de anos. A violência nesses locais foi retroalimentada, durante muito tempo, tanto pelas organizações do tráfico como por estruturas políticas que permitiram ações da polícia muitas vezes corruptas e igualmente violentas e não garantiram os direitos de cidadania das populações. Em nosso entender, se as UPPs conseguirem se firmar como uma nova política de segurança pública, para além dos grandes eventos esportivos internacionais, poderão contribuir para oferecer condições cada vez melhores de desenvolvimento dessas áreas. Afinal, a diminuição da violência resulta não apenas na diminuição de mortes prematuras, como também tem relações imbricadas com a promoção da saúde em seu sentido mais amplo e consequentemente com a qualidade de vida e a existência de condições para o desenvolvimento social e econômico dessas áreas.

No capítulo seguinte, veremos que a consolidação da pacificação, ao proporcionar um ambiente de paz, reforça as relações sociais existentes entre os moradores de favela. Possibilita, ainda, a criação de novos laços entre eles e o restante da cidade, costurando uma rede de maior integração urbana, na qual a sociodiversidade passa a ser valorizada como fonte de vitalidade urbana e não como justificativa para o preconceito social que essas áreas durante anos foram objeto. 
Mostraremos ainda que, ao se investir em ações socais promotoras do desenvolvimento humano, o governo aumenta as chances de consolidação da nova política de segurança pública. Amplia, também, a capacidade dos moradores de promover o desenvolvimento local por meio do empreendedorismo, contribuindo dessa forma para uma cidade mais sustentável. 


\section{PACIFICAÇÃO DAS FAVELAS E A PROMOÇÃO DO DESENVOLVIMENTO LOCAL}

A reconquista territorial das favelas pelo Estado, promovida pela ação da UPP, representa um passo importante rumo a uma maior integração das favelas com a cidade, que o jornalista Zuenir Ventura (1994) cunhou de cidade partida. Embora no caso específico do Rio de Janeiro não se possa considerar que as favelas tenham se desenvolvido completamente apartadas da vida urbana. Pelas próprias características geográficas da cidade, as favelas estão presentes por toda a parte, até mesmo no meio dos bairros mais ricos. Além disso, têm uma participação importante na vida cultural carioca. Berço do samba, as favelas, também, ditam outras manifestações culturais como o funk.

No entanto, diante do contexto do aumento da violência, a partir da década de 1980, Ventura (1994) constata uma divisão da cidade. O autor escreve seu livro depois de frequentar, durante dez meses, a favela de Vigário Geral, lugar onde ocorreu a chacina de 21 pessoas em agosto de 1993. É com o olhar de quem rompe a perspectiva míope de uma classe média ilhada na Zona Sul e descortina esse outro mundo onde a violência perpassa todas as esferas da vida, que Ventura apresenta o fosso que separa as duas realidades.

Como explicam Henriques e Ramos (2011, p. 243), a violência que contribuiu para essa divisão da cidade se distingue, no caso do Rio de Janeiro, por características que lhe são "únicas no cenário nacional e raras no cenário internacional". O controle de amplos territórios urbanos por mais de duas décadas por grupos criminosos é uma das mais emblemáticas. Tal controle se estende desde o domínio territorial, passando por uma interferência na relação com o próprio Estado quando intervém no funcionamento da maioria dos serviços públicos, até a esfera das relações privadas (ibid, p. 245).

Por essas particularidades da violência carioca, as UPPs foram concebidas para serem diferentes de outras experiências de segurança pública. O programa não almeja ser "um amplo programa de prevenção policial da criminalidade em todo o território urbano, mas [...] um processo específico de retomada de territórios controlados por criminosos" (HENRIQUES; RAMOS, 2011, p. 243).

A retomada dos territórios, realizada em um primeiro momento com sua ocupação pelas forças policiais, deve ser uma oportunidade para mostrar nova forma de agir da própria polícia, pacificada e contínua (HENRIQUES; RAMOS, 2011, p. 244). No entanto, como ressalta Jorge da Silva, ex-secretário estadual de Direitos Humanos do Rio de Janeiro (2012), embora a questão de como empregar a polícia seja importante, a luta contra a violência deve ir além da ação policial. "[...] O real desafio que se coloca ao poder público e à sociedade civil é saber como promover a integração dos diferentes segmentos sociais, e 
essa não é uma questão policial ou militar" (Silva, 2012 , p. 395). Essa percepção reflete não apenas a vivência acadêmica de Silva, como cientista social, professor da UERJ, mas a sua experiência profissional na polícia militar, como ex-chefe do Estado- Maior Geral e sua história pessoal, pelo fato de ter nascido e ter sido criado no Complexo de Favelas do Alemão, considerada uma das regiões mais violentas da cidade.

"Experiências nacionais e internacionais reforçam a ideia de que políticas de prevenção à violência são mais exitosas quando agregadas a ações mais amplas da área social, como educação, esporte e cultura" (NUNES, 2013, p.107).

Dentro dessa perspectiva, dando sequência ao trabalho iniciado com as UPPs, foi concebido o programa UPP Social, em 2010, pela Secretaria Estadual de Assistência Social e Direitos Humanos (SEASDH). Na época, o secretário estadual responsável por essa pasta era Ricardo Henriques.

Com o objetivo de dar sustentabilidade ao processo de pacificação, o programa nasce visando integrar as diversas ações sociais voltadas a esses territórios. Sua execução é direcionada à promoção da cidadania e ao desenvolvimento socioeconômico das áreas pacificadas para "à superação da situação de exceção", que durante tanto tempo as caracterizou, e melhor integrá-las ao restante da cidade (HENRIQUES; RAMOS, 2011, p. 245).

Em 2011, com a indicação de Henriques para a presidência do Instituto Municipal de Urbanismo Pereira Passos (IPP-Rio), o programa sai da esfera estadual e migra para a Prefeitura do Rio de Janeiro, por meio de um acordo entre os governos do estado e da cidade do Rio de Janeiro, passando a ser coordenado pelo IPP.

Nesse mesmo ano, devido a um acordo de cooperação entre a prefeitura da cidade e a ONU-Habitat, o Programa das Nações Unidas para os Assentamentos Humanos, a UPP Social passa a contar com a participação desse organismo internacional. "A ONU-Habitat apoia o Instituto Pereira Passos no gerenciamento global do programa e na produção de dados, análises e monitoramento de cada território da Rio+Social"11.

Ao migrar para a esfera municipal, o decreto de sua criação enfatiza a necessidade de coordenar as diversas ações envolvidas na política de pacificação, assim como o papel da prefeitura nesse sentido.

\footnotetext{
${ }^{11}$ Disponível em: <http://www.riomaissocial.org/>. Acesso em: 27 jul. 2015.
} 


\section{Decreto de criação da UPP Social:}

Considerando a necessidade de união de esforços entre União, Estados e Municípios para a garantia do sucesso das Unidades de Polícia Pacificadora,

Considerando o papel de enorme relevância que comete à Prefeitura no âmbito da política de pacificação,

Considerando a necessidade de integrar as ações sociais e os diversos serviços públicos sob a responsabilidade da Prefeitura nas comunidades pacificadas,

Fica instituída a UPP Social Carioca (Diário Oficial do Município do Rio de Janeiro, Decreto nํ33.347, de 3 de janeiro de 2011).

Em agosto de 2014, o programa UPP Social foi renomeado, passando a se chamar Rio + Social, em numa tentativa de dissociá-lo do programa de segurança pública (FERNANDES, 2014).

Em torno da pacificação, o programa é composto por dez diretrizes de ação. São elas: cidadania e convivência; legalidade democrática; superação da violência juvenil; integração territorial e simbólica; redução da pobreza; desenvolvimento humano; inclusão produtiva e dinamização econômica; qualidade de vida; diversidade e direitos humanos; infraestrutura e meio ambiente.

$\mathrm{Na}$ Figura 7, as dez diretrizes aparecem reagrupadas em torno de dois temas: consolidação da pacificação e desenvolvimento social. Embora essas diretrizes estejam interligadas em uma noção mais ampla de desenvolvimento social, fica clara a prioridade de se assegurar condições mínimas para a garantia dos direitos civis dos moradores. As quatro diretrizes associadas ao tema da consolidação da pacificação são apresentadas como cidadania e convivência, legalidade democrática, superação da violência juvenil e integração territorial e simbólica. 


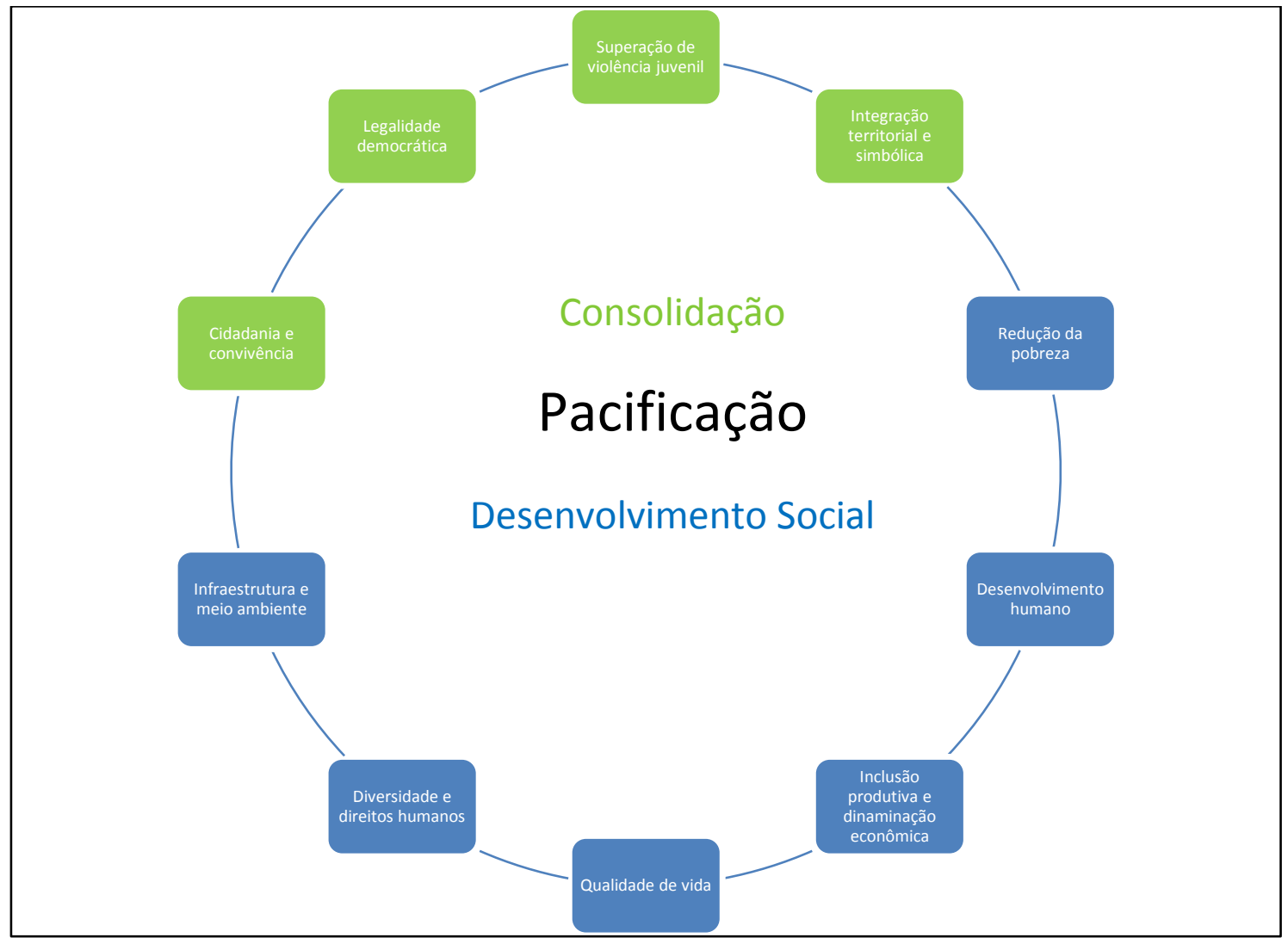

Figura 7 - Diretrizes da política UPP Social

Fonte: Henriques; Ramos, 2011, p. 248.

As diretrizes voltadas ao desenvolvimento social e econômico são parte importante do programa, embora, como pontuam seus idealizadores, "as favelas do Rio não sejam necessariamente os territórios com os piores indicadores socioeconômicos da cidade" (HENRIQUES; RAMOS, 2011, p. 249). Em 2000, os bairros que apresentaram o pior IDS foram os localizados na Zona Oeste da cidade, entre eles Guaratiba, Vargem Pequena, Vargem Grande e Camorim com IDS em torno de 0,4 (0,433; 0,425; 0,408 e 0,369 respectivamente) e Grumari, cujo IDS de 0,277 faz com que este bairro tenha a pior colocação nesse ranking. O IDS baixo desses bairros, especificamente, deve-se ao fato de serem bairros em fase de transição de uma situação rural para urbana e por isso não contam com serviços de infraestrutura desenvolvidos (CAVALLIERI; LOPES 2008).

As ações de fomento do desenvolvimento socioeconômico, tais como as que visam à redução da pobreza, ao desenvolvimento humano, à inclusão produtiva e à dinamização econômica, estão fortemente relacionadas ao tema de nosso trabalho. Ao explorarmos a questão da promoção do desenvolvimento local, por meio da geração de renda com o trabalho artesanal, e sua relação com a atual política de pacificação nas favelas, poderemos oferecer alguns elementos para se avaliar em que medida a política das UPPs cumpre seu papel, para além da garantia da segurança. 


\subsection{A POLÊMICA DA INTEGRAÇÃO DAS FAVELAS À CIDADE}

A integração territorial e simbólica é outro eixo norteador que se destaca no programa UPP Social. Além de estar entre os dez eixos que irão conduzir suas ações, aparece explicitada dentre os três objetivos do programa e compõe o seu slogan: "Rio 2016 - Cidade Integrada". Ela refere-se "à criação e valorização de espaços públicos de convivência e lazer, abertura de vias de acesso e circulação e aprimoramento dos transportes públicos locais, mapeamento e divulgação de serviços e atrações culturais, turísticas e de lazer, promoção da integração dos seus moradores com o entorno e o restante da cidade" (HENRIQUES; RAMOS, 2011).

Dentre os objetivos da UPP Social, destacam-se:

1. Assegurar a consolidação do controle territorial e da pacificação nas áreas das Unidades de Policia Pacificadora (UPPs);

2. Promover a cidadania e o desenvolvimento social e econômico dessas áreas;

3. Efetivar a integração plena dessas áreas ao conjunto da cidade. (NUNES, 2013, p. 111).

Como sublinha Valladares (2005), a ideia da existência de um apartheid social na sociedade brasileira não é nova e baseia-se na polarização favela/asfalto. No entanto, há quem questione a falta de integração entre as favelas e o restante da cidade. Nunes e Moura (2013, p. 101), por exemplo, defendem que as favelas são tão intrinsecamente associadas à imagem do Rio que chega a ser impossível imaginá-lo sem elas "[...] e toda a energia que dali brota e que enriquece a cultura metropolitana".

Valladares (2005) critica a caracterização das favelas na literatura como um objeto de estudo específico, homogêneo, dono de uma identidade própria, distinta do restante da cidade, e representante único do lugar da pobreza urbana. Essa visão, em seu entender, dogmática, reduz a diversidade existente nas favelas, contribuindo para aumentar ainda mais o estigma em torno delas.

A ideia de que nas favelas faltam projetos sociais tampouco é precisa. Henriques e Ramos (2011) citam um levantamento realizado, em setembro de 2010, para a Secretaria de Assistência Social e Direitos Humanos, que mapeou 132 projetos em desenvolvimento em favelas cariocas, frutos apenas da iniciativa governamental. Nesse número não estavam contabilizadas as ações das inúmeras ONGs que atuam nesses locais. Embora numerosos esses projetos de governo são criticados por serem implantados de forma descoordenada, fazendo com que em algumas áreas existam ações sobrepostas e em outras os esforços de investimento público não cheguem para todos ( HENRIQUES; RAMOS, 2011). 
Mesmo políticas públicas já consolidadas, como, por exemplo, a voltada ao saneamento, não alcançam todas as famílias. Durante a fase de implantação das UPPs nas favelas, Henrique e Ramos (2011) explicam que esses problemas são explicitados nos discursos dos políticos, das lideranças comunitárias e das autoridades policiais. A participação do Estado nesses locais é questionada e tida como paradoxal. Se por um lado há uma grande quantidade de projetos sociais, por outro o Estado é considerado ausente. “(...) "A ausência do Estado" expressa duplamente a ideia de displicência em relação à oferta de infraestrutura e de bens púbicos fartos e de boa qualidade e a falha na essência da função do Estado, o monopólio da força" (HENRIQUES; RAMOS, 2011, p. 250).

Assim, como explica Nunes (2013, p. 112), a UPP Social nasce com a missão de "coordenar as atividades daqueles que já atuam nas favelas". Para isso, adota um modelo de atuação que irá buscar a integração das políticas em andamento e das diversas ações provenientes da iniciativa privada e da sociedade civil, compartilhando informação e evitando a sobreposição de esforços.

Para integrar e coordenar as diversas ações sociais, o programa UPP Social, em sua fase de implantação, procura identificar as demandas das comunidades e direcionar as ofertas de serviços e bens públicos. Para isso, a primeira etapa do trabalho consiste em conhecer de perto a realidade de cada território (NUNES, 2013, p. 121).

Joana Nunes prestou consultoria para o Programa UPP Social, de junho de 2011 a junho de 2012, acompanhando a implantação do programa. Dos 16 fóruns realizados pela UPP Social nas comunidades, até 2012, a cientista política participou de 13. Nesses fóruns, pôde constatar que os agentes da UPP Social deparavam-se com problemas muito heterogêneos, pois as "favelas são áreas marcadas por todo tipo de carência" (NUNES, 2013, p. 129).

No entanto, embora as favelas sejam conhecidas como "territórios de deficit", não devem ser consideradas territórios desprovidos de capital. Esse capital é expresso, por exemplo, na existência de laços sociais fortes entre seus moradores, levando-os a desenvolver uma capacidade de improvisação diante das dificuldades materiais e na construção de "práticas sociais peculiares ao ambiente, numa multiplicidade de ações, (e) de táticas de sobrevivência" (NUNES; VELOSO, 2010, p. 25).

O controle da violência e a promoção do desenvolvimento local nas favelas por meio da consolidação da nova política de segurança pública resultam numa maior valorização dos espaços públicos de convivência nessas áreas, possibilitando que os laços sociais entre os moradores se estreitem. Esses laços sociais, como veremos a seguir, além de constituírem parte importante do capital social dessas áreas, fortalecem as iniciativas empreendedoras. 


\subsection{CAPITAL SOCIAL}

Não ignorando a precariedade das condições de vida de seus moradores, nosso interesse é mostrar que a "ideia de carência ['comunidades carentes'], de falta, é insuficiente para entender [a favela]" (ALVITO, 2006, p. 21). Os laços sociais existentes nesses locais remetem ao sentimento de pertencimento a um grupo e contribuem para a transformação das favelas em "verdadeiros contra modelos de territórios urbanos de resistência" [...] 'ao' padrão hegemônico de cidade" (NUNES; VELOSO, 2010, p. 16).

O conceito de capital social, embora venha sendo vulgarizado de forma pouco precisa e muito abrangente, tem um significado que não é novo para os sociólogos: ele nos remete à compreensão de "que o envolvimento e a participação em grupos possa ter consequências positivas para o indivíduo e para a comunidade [...]" (PORTES, 2000, p. 133).

A ideia do conceito já estava presente na teoria sociológica clássica. No entanto, para efeito do interesse desse trabalho em destacar a contribuição do capital social na superação de adversidades socioeconômicas e no fortalecimento do desenvolvimento local de comunidades, serão focadas as definições de três autores contemporâneos: Bourdieu(1986), Putnam (2000) e Coleman (1988).

Bourdieu define capital social como "o agregado dos recursos reais ou potenciais os quais estão ligados à posse de uma rede durável de relações mais ou menos institucionalizadas de conhecimento ou reconhecimento mútuo" (BOURDIEU, 1986, p.248, traduzido). Para o autor, as relações sociais, mantidas por trocas simbólicas ou materiais, serviriam como uma espécie de passaporte para os indivíduos terem acesso a recursos aos quais, sozinhos, não teriam.

Putnam conceitua capital social a partir de um estudo comparativo entre duas regiões da Itália, o Norte e o Sul do país. Conclui que as diferenças regionais de desempenho institucional não dependiam da riqueza, mas, sim, do capital social acumulado pelas sociedades (cultura política construída historicamente) (PUTNAM, 2000). O autor destaca a importância de "aspectos da organização social, como confiança, normas e sistemas, que contribuam para aumentar a eficiência da sociedade" [...]. E diz que, "assim como outras formas de capital, o capital social é produtivo, possibilitando a realização de certos objetivos que seriam inalcançáveis se ele não existisse" (PUTNAM, 2000, p. 177).

Coleman, assim como Putnam, analisou o capital social sob o ponto de vista de sua função, procurando descrever os efeitos das relações sociais. Ao estudar o desempenho escolar de crianças e jovens, por exemplo, Coleman mostra que em lares onde os pais se 
dedicam mais aos filhos, estes terão um desenvolvimento intelectual superior. O capital social, neste caso, estaria expresso na relação que as crianças possuem com seus familiares. Pais que se empenham apenas na vida profissional, por mais capital humano que possuam (forte formação intelectual, por exemplo), não conseguem reverter esse capital para a formação de seus filhos. Além de estudar o capital social presente nas relações familiares, Coleman estendeu seus estudos, mostrando a importância do capital social inerente à vida comunitária para todos aqueles que fazem parte da estrutura social em questão. Neste caso, o capital social contribui para reforçar normas e possibilitar a troca de informações que regulam o acesso a recursos (COLEMAN, 1988).

Importante ressaltar que o conceito de capital social contribui para romper com a hegemonia do individualismo que fundamenta a civilização moderna e que considera a sociedade como um aglomerado de indivíduos autônomos, cada um agindo por conta própria. Afinal, valoriza as relações sociais como recursos, "como um ativo de capital de que os indivíduos podem dispor" (ABRAMOVAY, 2000, p. 382).

Para análise da contribuição do capital social no fortalecimento do empreendedorismo social como uma das possibilidades de fomento ao desenvolvimento local sustentável, buscamos uma abordagem sobre o desenvolvimento diferente daquelas que o reduzam ao crescimento do Produto Interno Bruto (PIB).

Escolhemos adotar a visão de Amartya Sen para quem o desenvolvimento deve conduzir a "atenção para os fins que o tornam importante" (SEN, 1999, p. 17). Para este autor, o desenvolvimento estaria representado por um processo de expansão de liberdades de escolhas, que dotariam as pessoas de meios para enfrentar problemas como a pobreza, a carência de oportunidades econômicas e sociais, em especial para as mulheres, e a negligência de serviços públicos que garantam, entre outros aspectos, a paz e a ordem local. Problemas facilmente identificáveis, por exemplo, em áreas de grande vulnerabilidade social como é o caso das favelas urbanas.

Sen considera que, "com oportunidades sociais adequadas, os indivíduos podem efetivamente moldar seu próprio destino e ajudar uns aos outros" (SEN, 1999, p. 23). A partir dessa emancipação, as pessoas podem se transformar em agentes, não precisando ser tratadas como "beneficiários passivos de engenhosos programas de desenvolvimento" (SEN, 1999, p. 26).

Outro autor que caminha na mesma direção de Amartya Sen e contribui para uma crítica ao liberalismo econômico, expondo suas limitações como paradigma de desenvolvimento é Hassan Zaoual. O autor questiona o pensamento global econômico, dizendo que este, ao tratar o homem como um homo oeconomicus, desprovido de valores 
culturais e éticos, é reducionista em sua essência e não condizente com a possibilidade de uma sociedade e uma economia sustentáveis (ZAOUAL, 2006, p. 20).

Ele avalia os resultados das tentativas de implementação de modelos de economia transpostos em países do Hemisfério Sul. Diante dos "impasses da economia formal e a expansão sem precedente da economia informal” (Zaoual, 2006, p.15) nesses países, constata o fracasso desses modelos econômicos.

Além de inadequados a esses países, tais modelos apresentam, também, sinais de esgotamento nos países do Hemisfério Norte. Nos países do continente europeu, parecem não conseguir dar conta de conduzir restruturações necessárias para solucionar questões prementes como o desemprego em massa e o apartheid territorial. Essa realidade baseada em fortes contrastes sociais e territoriais seria, como sublinha Zaoual, a mesma encontrada nas cidades brasileiras: "de um lado, bairros bem cuidados e ainda bem estruturados (bairros residenciais de classe média) e, de outro, bairros deteriorados, essencialmente ocupados por populações marginalizadas e não assistidas pelo poder público (trabalhadores pobres, desempregados, migrantes etc.)" (ZAOUAL, 2006, p. 16).

Zaoual propõe uma abordagem conceitual diferente para fazer frente a esse homo oeconomicus, base do saber econômico que reduz "o homem a um animal voltado para a produção e o consumo" (ZAOUAL, 2010, p. 15). Sua teoria dos sítios simbólicos de pertencimento, apoiada no conceito do homo situs, dirá que "o ser humano necessita de um sítio, pois (é) neste espaço cognitivo de pertencimento, que (se) estabiliza o caos social a que o ser humano se sujeita" (SIMONI, 2011, p. 180).

Ao considerar "as múltiplas motivações dos atores da situação e do conjunto das relações sociais que garantem a fluidez de suas trocas", Zaoual (2006, p. 19) expande a noção de realidade econômica para além do mercado. O sítio funcionaria como uma "mão invisível" que participaria da vida econômica e social, ditando códigos de conduta por meio de valores como solidariedade, cooperação e socialização.

O homem para Zaoual é "antes de tudo um animal territorial". É com seu território, repleto de história e significados simbólicos, que ele irá tecer sua trajetória individual e coletiva. Essa relação do homem com seu território, segundo o autor, pode ser percebida de forma clara na economia informal, na qual as redes de pertencimento adquirem uma importância ímpar, assegurando "mais coesão e mais certeza para facilitar as transações econômicas" (ZAOUAL, 2006, p. 20).

O território irá impelir o homem a interagir com o meio em que vive e com as pessoas que fazem parte de sua realidade empírica, diferente da postura mais individualista exigida pelo pensamento econômico voltado exclusivamente a atender as exigências do mercado. 
Dessa forma, Zaoual conclui que enquanto "a mão invisível [...] de Adam Smith, apóstolo do capitalismo industrial, leva o homem à atomicidade; [...] o sítio tende a lhe impor a comunidade" (ZAOUAL, 2006, p. 77).

É nessa força da comunidade, da cooperação, do sentimento de pertencimento, das redes construídas, na diversidade das construções sociais e econômicas que estariam assentadas as bases de um novo paradigma de sustentabilidade para conduzir as relações do homem com o seu entorno.

Ao voltar seu olhar para o território, para o local em oposição ao global, e a partir dele construir sua teoria dos sítios, Zaoual explica que esses conceitos não devem ser entendidos de forma absoluta. Assim como a noção de espaço para Einsten, o local para Zaoual é uma noção construída pelo observador. Representado pelos vínculos sociais e pelas crenças compartilhadas, este local será delimitado pelo sentimento de pertencimento. Na mesma direção de Amartya Sen (2000), que entende o crescimento econômico para além do PIB, Zaoual irá dizer que o sítio extrapola o quantificável, não se reduzindo, também, ao PIB.

Palco da diversidade de relações econômicas e sociais em que o homem está envolvido, o sítio oferece a ele um sentido para a própria existência, a partir da relação que constrói com o outro, com o mundo e com o universo. Neste contexto, Zaoual destaca a importância das redes de relação. Ele irá atribuir a elas um papel fundamental para o desenvolvimento local, lembrando que, na África, o fato de estar ou não conectado a essas redes é um critério para se definir pobreza: “Pobre é quem é solitário" (ZAOUAL, 2006, p. 51).

Entendemos que o processo de pacificação das favelas, ao favorecer a convivência pacífica, reforça as relações e a coesão social. E, assim, pavimenta uma possiblidade de desenvolvimento para esses territórios marcados pela exclusão social.

Nesses locais, "onde a improvisação e a dificuldade material produzem espaços precários, porém com elevada dose de socialibidade" (NUNES; VELOSO, 2010, p. 25), a coesão social "costuma evocar um anseio da comunidade diante de um cenário de globalização e de transformações profundas que muitos associam à maior fragmentação social e à perda de laços estáveis". (CEPAL, 2007, p. 23).

Tanto Zaoual como Sen irão mostrar que "a economia é incapaz de propor conceitos universalmente indiscutíveis, tais como a utilidade e o bem-estar, sem considerar o contexto do agente econômico" (ZAOUAL, 2010, p. 15).

O pensar global e o agir local apregoado pelo alemão Ulrich Beck (BECK, 2010), em seu livro Sociedade de Risco - Rumo a uma outra modernidade, é dessa forma reforçado pelo autor marroquino. Zaoual ressalta a importância de uma reflexão sobre a realidade local, na qual os atores econômicos e sociais estão inseridos na busca de soluções para os 
problemas e incertezas que os cercam. "Em outros termos, a vida econômica local encontra um apoio em mecanismos de solidariedade instituídos pelo sítio de pertencimento" (ZAOUAL, 2010, p. 31).

O homo situs, alimentado pelo sentimento de alteridade, contribuiria, assim, para a organização de seu território, buscando fazer isso de forma sustentável. Afinal, esse homem necessita do seu "sítio simbólico para viver em paz e com felicidade, garantindo, assim, a sobrevivência das futuras gerações" (ALCOFORADO; CHACON, 2012, p. 2-3).

A importância da consciência de pertencer a um determinado local e a capacidade de organização das comunidades são fundamentais no desenvolvimento do empreendedorismo favelas. Como explica Zaoual,

"o empreendedorismo contemporâneo mostra que todas as dimensões negligenciadas pelos modelos físico-financeiros de gestão e a economia em geral desempenham um papel fundamental no dinamismo econômico: ética, identidade e solidariedade de grupo, tradições e culturas de comunidade, vínculo familiar e étnico, rede de pertencimento, efeitos sociais e espaciais de território etc." (ZAOUAL, 2006, p. 193).

Albagli e Maciel (2002, p. 2) sublinham a importância do empreendedorismo social e institucional como "expressão da capacidade de segmentos e organizações sociais, comunidades e instituições públicas organizarem e implementarem iniciativas pertinentes à melhoria das condições de vida locais e à abertura de oportunidades para grupos sociais menos favorecidos". Tal avaliação reforça nossa hipótese de pesquisa de que a maior presença do Estado, com a execução da atual política de segurança pública nos morros cariocas, promoverá um ambiente favorável para atividades empreendedoras.

Nesses territórios que trazem como marca o "descompasso entre a oferta de trabalhadores e a demanda por trabalho", típico das metrópoles brasileiras (NUNES; VELOSO, 2010, p. 12), o empreendedorismo representa uma opção de sobrevivência importante para as famílias. É isso que iremos abordar em nosso próximo item ao mostrarmos como essa alternativa econômica pode se converter em uma ferramenta importante de inclusão social.

\subsection{CRIATIVIDADE E SOLIDARIEDADE: FERRAMENTAS PARA O DESENVOLVIMENTO}

A produção artesanal, uma categoria de empreendedorismo que está sendo desenvolvida nas favelas cariocas, seria, a nosso ver, uma possibilidade econômica perfeitamente alinhada com a abordagem social dos sítios de Zaoual. Por meio dela, 
alcançaríamos a expansão do conceito do que seria o progresso humano e sua sustentabilidade.

Não é sem motivos que a economia criativa, na qual o artesanato se insere, vem ganhando cada vez mais relevância na pauta das tendências atuais no mundo e no Brasil. Ela tem mostrado ser uma opção especialmente interessante para o fortalecimento econômico e social principalmente dos países em desenvolvimento.

É uma fonte de criação de empregos, oferecendo oportunidade para a mitigação da pobreza [...]. Além disso, como muitas mulheres trabalham na produção de arte e artesanato, nas áreas relacionadas à moda e à organização de atividades culturais, a economia criativa também desempenha um papel catalítico na promoção do equilíbrio de gêneros na força de trabalho criativo. (DUISENBERG, 2008 apud LEITÃO; GANTOS, 2012, p. 5-6).

Baseada na utilização de um recurso não limitado pela noção de escassez, a economia criativa é, ainda, "não poluidora e tem como princípio a sustentabilidade. É uma economia que cresce no mundo todo" (Leitão, depoimento, julho 2013). A afirmação de Claúdia Leitão, ex-secretária de Economia Criativa do Ministério da Cultura, é confirmada pelo Relatório da Economia Criativa 2010 da Conferência das Nações Unidas para Comércio e Desenvolvimento (UNCTAD, 2010), no qual os setores criativos aparecem como os que mais crescem com sustentabilidade e inclusão no mundo.

O conceito nasceu na Austrália, no início da década de 1990. E ganhou força, no final dessa mesma década, quando o governo britânico lançou um programa de governo para o desenvolvimento estratégico de 13 setores criativos, entre eles o artesanato, objeto de nosso interesse.

No Brasil, o conceito adquiriu nova roupagem (Figura 8), passando a agregar, além da criatividade e inovação, uma dimensão maior que remete a "trabalho e renda, por meio da inclusão social, da diversidade cultural e do desenvolvimento humano. É nesse contexto, que cresce a importância da produção artesanal no Brasil" (Leitão, depoimento, julho $2013)^{12}$.

Outro conceito que vem sendo associado, no Brasil, como alternativa à geração de trabalho e renda, com o viés da inclusão social, é a economia solidária. Com a proposta de ser "um jeito diferente de produzir, vender, comprar e trocar o que é preciso para viver" (site da SENAES), a economia solidária ultrapassa a lógica estreita da economia tradicional. Enquanto esta se fundamenta no individualismo e no capital, a economia solidária tem como

\footnotetext{
${ }^{12}$ Entrevista realizada pela autora com a então Secretária de Economia Criativa, Cláudia Leitão. Brasília, 2 de julho de 2013.
} 
características a solidariedade entre seus membros, a autogestão do trabalho, a preocupação com o bem-estar de todos e com a preservação do meio ambiente.

A solidariedade que dá nome a esse tipo de economia perpassa todas as instâncias dessa forma de vida econômica. Pressupõe, por exemplo, a não exploração da força de trabalho, a justa distribuição dos lucros, a ampliação de oportunidades de capacitação para todos os seus membros, assim como a preocupação com o desenvolvimento sustentável de base territorial, regional e nacional (BRASIL, 2015) ${ }^{13}$.

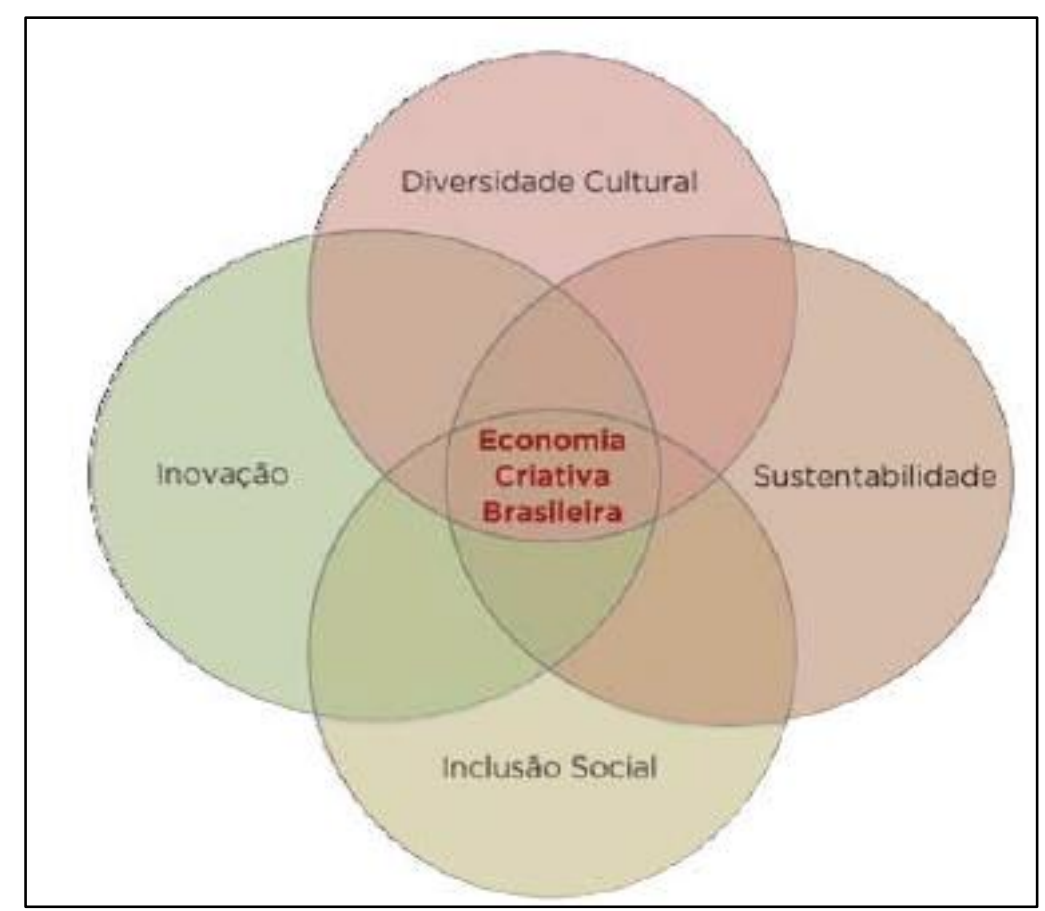

Figura 8 - Princípios norteadores da economia criativa no Brasil Fonte: Plano da Secretaria de Economia Criativa do MinC.

Segundo Genauto França Filho e Jean-Louis Laville (2004, p.21), as origens da economia solidária "relacionam-se, em geral, ao contexto de crise econômica mais ampla que afeta as diferentes economias do planeta. Tal crise vem minar as bases do mecanismo histórico de regulação das sociedades na modernidade, marcados pela sinergia entre Estado e mercado" . No entanto, os autores ressaltam que, embora esse aspecto econômico tenha um peso importante no surgimento da economia solidária, não pode explicá-lo em sua integralidade. A crise de valores que acompanha essa crise econômica e que leva a um

\footnotetext{
${ }^{13}$ Essas informações foram obtidas no site do Ministério do Trabalho e Emprego www.mte.gov.br/ecosolidaria/o-que-economia-solidária.htm. Acessado em 10/10/2015. Em maio de 2016, houve uma mudança no site em razão da junção das pastas do Trabalho e da Previdência Social.
} 
questionamento sobre o trabalho e suas formas de organização e produção também contribui para o desenvolvimento da economia solidária.

No Brasil, Paul Singer assinala que a economia solidária emergiu como uma estratégia de sobrevivência dos trabalhadores em um contexto marcado pelo empobrecimento e exclusão social. Tal contexto foi resultado do aumento do desemprego provocado pela forma como foi alcançada a estabilização dos preços com o Plano Real. Em função desse programa, foi realizada uma "abertura brutal do mercado interno às importações de bens industriais de países com custos trabalhistas muito menores que os vigentes no Brasil, o que acarretou forte crise industrial, com a perda de milhões de postos de trabalho" (Singer, 2013, p.18).

O fortalecimento da economia solidária contou, a partir de então, com o apoio de setores organizados da sociedade civil, como instituições religiosas, sindicatos e universidade. Essas entidades "difundem entre os trabalhadores sem trabalho e micro produtores sem clientes os princípios do cooperativismo e o conhecimento básico necessário à criação de empreendimentos solidários" (Singer, 2002, p. 113).

Como explica, em entrevista, Valmor Schiochet, diretor do Departamento de Estudos e Divulgação da Secretaria de Economia Solidária do MTE, no Brasil, o fenômeno abarca diversas composições. "Um conjunto de atividades econômicas podem ser organizadas a partir do princípio da economia solidária tanto durante a produção como na etapa de comercialização" (SCHIOCHET, depoimento, 2015).

Fundamentada nos princípios associativos, a economia solidária, no Brasil, está organizada predominantemente sob a forma coletiva e informal. Não diz respeito a um setor econômico específico, mas a processos organizativos das atividades econômicas. Em relação a esses processos, Schiochet explica que existem basicamente dois tipos de organização.

As organizações coletivas típicas em que os produtos e serviços são
resultados da atuação conjunta de um grupo de pessoas, que seriam
tipicamente cooperativas ou associações de trabalhadores em que se dá a
cooperação no processo de trabalho em si. E a segunda, que são as formas
associativas e cooperativas de produtores. As pessoas produzem bens
materiais e imateriais individualmente, de forma autônoma e se associam
para viabilizar essa produção ou a comercialização dessa produção. Então
se associam para compartilhar um espaço comum, para fazer aquisição de
insumos, compartilhar equipamentos ou para a comercialização
(SCHIOCHET, depoimento, 2015).

No trabalho de campo realizado para essa pesquisa, o segundo tipo de organização do trabalho foi o mais encontrado nas favelas do Rio de Janeiro. No grupo Coopa-Roca da Rocinha, no grupo Costurando Ideais da Favela Santa Marta, no grupo Mulheres Guerreiras 
do Morro da Babilônia, no grupo Devas na Favela Nova Holanda as mulheres dividem o mesmo espaço de trabalho e o mesmo equipamento.

Schiochet (depoimento, 2015) confirma essa percepção e explica que "é nessa segunda forma de pensar, de perceber a organização que se encontra o trabalho artesanal. Basicamente, os artesãos desenvolvem sua atividade de forma individual ou familiar, buscando se associar para viabilizar a comercialização"

Depois da agricultura familiar, Schiochet (depoimento 2015) explica que o artesanato representa a segunda maior categoria social de pessoas que estão na economia solidária (17\%). Dos 20.135 empreendimentos solidários existentes no país, 3.534 correspondem a empreendimentos que possuem como sócios indivíduos autodenominados artesãos. Esse valor não inclui trabalhadores agrupados em outras categorias da economia solidária, como, por exemplo, os agricultores familiares e os catadores de material reciclado que, também, produzem artesanato. Portanto, conclui-se que o número de empreendimentos voltados à produção do artesanato possa ser bem maior.

Até 9 de outubro de 2015, no Cadastro Nacional de Empreendimentos Econômicos Solidários haviam sido mapeados, no município do Rio de Janeiro, 301 empreendimentos solidários. Mais 45 empreendimentos estavam em processo de análise. Os 301 empreendimentos incluídos no cadastro contam com 8.039 sócios(as). Dentre os empreendimentos, os de artesanato somam 163, ou seja, mais da metade entre os mapeados. Eles contam com a participação de 2.302 sócias. Desse total, 1.945 são mulheres (informação do MTE enviada por e-mail, 9 de outubro de 2015).

A concepção que orienta a política de economia solidária, no Brasil, expressa "princípios não capitalistas de organização de trabalho e da economia" (depoimento, Schiochet, 2015). De acordo com esses princípios, os processos de organização das atividades econômicas devem ser geridos pelos princípios da autogestão e da participação democrática. O grande desafio, como sublinha Schiochet (depoimento, 2015), "é articular esses princípios com a viabilidade econômica".

Transformada em programa de governo, no Brasil, em 2003, a partir da criação da Secretaria Nacional de Economia Solidária, essa economia capilarizou-se nos governos estaduais e municipais. No Rio de Janeiro, materializou-se em forma de lei em 2012 (Lei no 5.435), quando foi instituída a Política Pública de Fomento à Economia Solidária na esfera da Prefeitura da cidade do Rio de Janeiro. Sua finalidade é assim expressa:

Art. 1ํㅜ Fica instituída a Política Pública de Fomento à Economia Solidária, na Prefeitura da Cidade do Rio de Janeiro, que se integra às estratégias gerais de desenvolvimento sustentável e aos investimentos sociais, tendo por finalidade a promoção de atividades econômicas autogestionárias, o 
incentivo aos empreendimentos econômicos solidários, bem como a criação de novos grupos e sua integração a redes associativistas e cooperativistas de produção, comercialização e consumo de bens e serviços.

No entanto, no ano anterior, a prática da economia solidária já era reconhecida pelo governo municipal. Em setembro de 2011, a prefeitura municipal do Rio de Janeiro, por meio de decreto, criava o Circuito Carioca de Economia Solidária (Decreto $n^{\circ}$ 34.388). Este circuito, que , a partir dessa data, promoveu a realização de feiras pela cidade, passou a dar uma visibilidade cada vez maior à produção artesanal desenvolvida nas comunidades pacificadas, constituindo-se em um importante canal de comercialização dessa produção.

Em 2011, além de fazer parte do escopo das ações da Secretaria Nacional de Economia Solidária do Ministério do Trabalho e Emprego, a produção artesanal pensada como instrumento do desenvolvimento social passa a ser objeto de política pública de outra pasta do governo federal. Em abril daquele ano, entrava em funcionamento a mais nova secretaria do Ministério da Cultura do Governo Dilma Rousseff, a Secretaria de Economia Criativa, instituída formalmente no dia $1^{\circ}$ de junho de 2012 (MADEIRA, 2014)

No final de 2011, foi lançado o Plano da Secretaria da Economia Criativa com as ações, diretrizes e políticas públicas para os diversos setores da economia criativa no Brasil, entre eles o artesanato. $O$ documento estabelece quatro eixos norteadores para essas políticas: "a diversidade cultural do país, a percepção da sustentabilidade como fator de desenvolvimento local e regional, a inovação como vetor de desenvolvimento da cultura e das expressões de vanguarda e, por último, a inclusão produtiva como base de uma economia cooperativa e solidária" (BRASIL, Ministério da Cultura, 2011, p.33).

No segundo semestre de 2015, como veremos no capítulo seis, a Secretaria de Economia Criativa é extinta no âmbito do Minc. Em outubro daquele ano, quando realizamos nossas entrevistas no Minc sobre as políticas voltadas ao artesanato, a coordenação da política do artesanato estava em fase de transição para a Secretaria de Cidadania e Diversidade. Embora a mudança ainda estivesse em curso, já era possível perceber que a nova gestão realçaria o artesanato mais como objeto de identidade cultural local.

As ações da antiga Secretaria de Economia Criativa apoiavam a cadeia produtiva do artesanato, explicitando uma preocupação voltada à inclusão social e ao desenvolvimento local, por meio da geração de trabalho e renda. Já a Secretaria de Cidadania e Diversidade mostrou, naquele momento, que pretendia utilizar a mesma lógica da economia solidária mais para o apoio à divulgação dos produtos culturais. 


\subsection{SUSTENTABILIDADE URBANA}

Depois de um longo período de domínio territorial de grupos criminosos sobre grandes áreas ocupadas por favelas, o Rio de Janeiro tem passado, nos últimos anos, por um período de revitalização urbana marcada pela implantação das UPPs e por obras de infraestrutura e ressignificação dos espaços urbanos, para atender a realização dos grandes eventos esportivos internacionais. Todas as mudanças decorrentes desse processo conduzem a uma reflexão sobre o que se espera alcançar e sobre os fatores que possam contribuir para a sustentabilidade urbana.

Para pensarmos a questão da sustentabilidade urbana, partiremos do conceito de cidades utilizado por Louis Wirth (1967), um dos teóricos da Escola de Chicago, berço da Sociologia Urbana. O autor, ao buscar uma definição sociológica das cidades, sublinha algumas de suas características que irão diferenciá-las como forma específica de associação humana. Dentre elas, destaca, por exemplo, a heterogeneidade de seus indivíduos, chegando assim a uma imagem simbólica da cidade como mosaico de diferentes mundos sociais.

Nesse mosaico, a população urbana é selecionada e distribuída em locais mais ou menos distintos, de acordo com fatores, como: "local e a natureza do trabalho, a renda, as características raciais, étnicas, o status social, os costumes, hábitos, gostos, preferências e preconceitos" (WIRTH, 1967, p. 102). No ambiente urbano, a interação social entre os diferentes indivíduos quebra a rigidez das castas comum nas sociedades tradicionais e produz uma fluidez que confere a esses indivíduos status diferentes nos diversos grupos sociais aos quais se filiam, sem necessariamente se fidelizar a nenhum em especial. Wirth explica que essa mobilidade contribui para "a sofisticação e o cosmopolitismo do habitante da cidade" (WIRTH, 1967, p. 103).

Ao considerar as cidades como contínuos polos de atração da população rural e não como um produto de uma criação instantânea, Wirth nos chama a atenção para o fato de, nelas, junto ao que se pode distinguir como um modo de vida urbano, coexistirem modos de vida associados a sociedades rurais, anteriores (WIRTH, 1967). Será a partir dessa capacidade de reunir migrantes do interior, de outras cidades e até de outros países, transformando-se em um "cadinho das raças, dos povos e das culturas e o mais favorável campo de criação de novos híbridos biológicos e culturais", que a cidade retroalimenta a heterogeneidade que Ihe é característica e útil (WIRTH, 1967, p. 97). A vantagem de reunir indivíduos tão diferentes em um mesmo espaço geográfico é possibilitar uma maior segmentação de papéis sociais em um mercado de trabalho cada vez mais especializado, para atender às diferentes necessidades da vida urbana. 
A partir do entendimento da cidade como um mosaico de mundos sociais, percebemos as favelas como parte dela. Essa visão opõe-se à política de segregação espacial implantada pelo prefeito Pereira Passos, no início do século XX. Passos, inspirado na reforma urbana realizada em Paris pelo prefeito Hausmann, no final do século XIX, e apoiado por uma campanha higienista, capitaneada por Oswaldo Cruz, foi responsável pela maior reforma urbana até então realizada na cidade. Mandou demolir os locais de moradia dos pobres no centro do Rio de Janeiro em uma campanha que ficou conhecida como Bota-abaixo, desabrigando uma grande massa de pessoas para abrir avenidas e facilitar a reforma sanitária.

Posteriormente, na década de 60, essa política de segregação espacial no Rio de Janeiro é retomada com a transferência dos moradores das favelas da Zona Sul para as periferias da cidade. As remoções, nessa época, são realizadas em proporções inéditas (Brum, 2013, p.180). O governador Carlos Lacerda dá início a essa era, que ficou conhecida como a "era das remoções' (de 1963 a 1975), na qual foram removidas mais de 175 mil pessoas no Rio de Janeiro" (PAULO, 2013 ${ }^{14}$ ). Mas foi a partir do golpe militar de 1964, que a política de remoção das favelas ganha impulso e passa a ser executada "com força total, garantida por uma repressão nunca vista antes" (BRUM, 2013, p. 180).

O favelado, como explicam Mário Brum (2013) e Janice Perlman (1977), era visto como um ser não integrado à dinâmica da cidade, apesar de a elite usá-lo como mão de obra para diversos trabalhos que tornavam a vida urbana, se não possível, ao menos mais confortável. Assim, sob os ombros dessas mesmas pessoas que exerciam trabalho de porteiros dos prédios, faxineiros e faxineiras, babás, empregadas domésticas, peões e garçons, pairava toda a responsabilidade pela relação conflituosa da cidade com as favelas.

Na virada da década de 1970 para 1980, e com o início do processo de redemocratização, a ameaça de remoções das favelas parecia ceder lugar a uma nova forma de se pensar a cidade. No início da década de 1990, seguindo uma exigência da Constituição de 1988, é instituído o Plano Diretor da Cidade do Rio de Janeiro e "em consonância com os princípios do Plano Diretor surge o [...] o programa Favela Bairro, (consolidando) a urbanização das favelas (BRUM, 2013)".

\footnotetext{
${ }^{14}$ Entrevista à Agência Pública, Paula Paiva Paulo, autora do estudo "Do 'Ponha-se na Rua' ao 'Sai do Morro Hoje': das raízes históricas das remoções à construção da 'cidade olímpica'").
} 
Contudo, como lembra Brum (2013), embora afastada, a ameaça de remoção não desapareceu por completo. Durante a década de 1990, "a violência urbana passou a ser identificada como o principal problema causado pelas favelas (...). (E) foi se tornando um dos principais argumentos utilizados pelos defensores da remoção" (BRUM, 2013, p. 193).

Recentemente, o tema volta à pauta, devido aos Grandes Eventos, como a Copa do Mundo e as Olimpíadas. No entanto, o autor percebe diferenças da atual política para favelas de Eduardo Paes em relação àquelas do período auge das remoções. Brum (2013) destaca que, diferente do período da ditadura, a conjuntura democrática tem permitido que os moradores de comunidades busquem o apoio de outros atores para resistirem às remoções. Além disso, as remoções propostas atualmente pela prefeitura envolvem a transferência de moradores para locais próximos de onde moravam e não mais, como antes, para os subúrbios distantes.

No entanto, o autor ressalta que, se os Grandes Eventos estão sendo considerados pelo governo como uma janela de oportunidade para a cidade, é preciso lembrar que "os moradores de favelas do Rio e aqueles que lutam por uma cidade mais justa esperam que as oportunidades não sejam meramente de aprofundar as desigualdades urbanas, mas de construir uma cidade mais justa e solidária" (BRUM, p. 202).

E o que seria uma cidade mais justa, mais solidária e mais sustentável? Nesse período em que a cidade do Rio de Janeiro passa por inúmeras transformações, resultantes de todos os investimentos que estão sendo feitos para a realização dos Grandes Eventos, a questão da sustentabilidade urbana se mostra particularmente oportuna.

Reiteramos a visão dos urbanistas Carlos Leite e Juliana Awad, que destacam o papel da diversidade socioterritorial como fator de sustentabilidade urbana. Para os autores, "não há cidade sustentável, sem a desejável diversidade socioterritorial" (LEITE; AWAD, 2012, p. 17).

Ao se pensar em uma via sustentável de retomada de desenvolvimento para a cidade, é preciso que o Rio de Janeiro estenda os legados das últimas transformações urbanísticas para todos, incluindo, é claro, a população das favelas. Para isso, é preciso que seja reinventado o padrão de coexistência territorial e de sociodiversidade.

Sob a ótica da sustentabilidade urbana, Leite e Awad (2012) propõem que as cidades devam crescer investindo em maior compactação ao invés de expansão territorial. A cidade, organizada em redes de núcleos policêntricos compactos e densos, alcançaria uso mais racional e sustentável dos recursos sem ter que avançar por territórios verdes. 
Em relação a essa busca pelo desenvolvimento urbano sustentável, os autores sublinham que, por meio da restruturação produtiva, "reciclar o território é mais inteligente do que substituí-lo" (LEITE; AWAD, 2012, p. 13).

Ao se referir ao conceito de desenvolvimento sustentável discutido no Relatório Brundtland (1987) que aponta para a necessidade do desenvolvimento integrar as dimensões sociais, econômicas e ambientais, Leite e Awad (2012) destacam a importância da adoção de padrões de sustentabilidade que levem em conta o combate à pobreza.

Os autores lembram que, se as cidades, hoje, são os locais das grandes transações econômicas e interações sociais e culturais, são, também, locais de pobreza e de exclusão social. Estimativas da ONU indicam que, nas cidades, 1 bilhão de pessoas vivem em favelas atualmente, em 2050, serão 3 bilhões de pessoas vivendo nesses locais. (ONU, 2013).

No entanto, apesar da desigualdade social que caracteriza a explosão urbana contemporânea, principalmente nos países em desenvolvimento, Leite e Awad afirmam que as cidades nunca foram tão atrativas. "As pessoas se mudam para as cidades em busca de uma vida melhor, e normalmente conseguem, mesmo vivendo em favelas. Ainda que vivendo em condições precárias nas grandes cidades, a população vai a elas porque sabe que é ali que estão as oportunidades (...)" (LEITE e AWAD, 2012, p. 22).

Para fazer frente a esse intenso processo de urbanização global, Leite e Awad ressaltam que é preciso direcionar o desenvolvimento das cidades para a maioria, ou seja, os pobres. O desafio não é pequeno, pois as projeções mostram que "nas próximas duas décadas as cidades de países em desenvolvimento concentrarão $80 \%$ da população do planeta" (LEITE; AWAD 2012, p. 24).

Outra autora que sublinha a importância da diversidade nas cidades é a jornalista e urbanista Jane Jacobs (2000). A autora diz que a diversidade é representada, por exemplo, pela grande variedade de opções culturais e de usos econômicos que a cidade oferece do seu espaço urbano e de sua população, nos remetendo ao que Wirth (1967) fala sobre heterogeneidade dos diferentes mundos sociais presentes nas cidades.

Considerada por Jacobs (2000) como natural das grandes cidades, a diversidade, em seu entender, é alimentada, entre outros fatores, pela alta densidade populacional no espaço urbano. No entanto, a autora ressalta que "existem coletividades urbanas enormes, em que a presença das pessoas não gera nada além de estagnação e, por fim, um descontentamento definitivo com o lugar" (JACOBS, 2000, p. 163). Para Jacobs, a alta densidade populacional terá resultados positivos quanto maior for a interação entre seus habitantes. Para isso, ela diz que a cidade deve provocar "a capacidade dos moradores de 
interagir economicamente e de ajudar a formar uma combinação efetiva de usos (para o espaço urbano) (JACOBS, 2000, p. 163)".

Para a autora, a alta concentração de pessoas em um mesmo espaço geográfico e a diversidade típica das grandes cidades são "fontes de imensa vitalidade" (JACOBS, 2000, p. 244) urbana e estão indissociavelmente atreladas a uma possiblidade viável de desenvolvimento para esses locais.

A importância da sociodiversidade nas cidades, também, é sublinhada por Jaime Lerner, consultor da ONU para assuntos de urbanismo. Para ele, "uma cidade deve promover em seu território a integração entre funções urbanas, níveis de renda, faixas etárias, etnias. Quando maior a mistura, mais humana a cidade será" (LERNER, 2015).

Maior diversidade e maior integração social, segundo Lerner, podem contribuir de forma positiva para a vida urbana. "Uma cidade onde existe a diversidade, e onde um presta serviços para o outro a tendência é reduzir-se a violência. Quanto mais as pessoas usarem a cidade, menos violência a cidade terá" (LERNER, 2012).

Lerner (2015), que explica a sustentabilidade como "uma equação entre o que é economizado e o que é desperdiçado", destaca, ainda, a questão da mobilidade como fator a ser considerado para a melhoria da qualidade de vida nas cidades e a relação delas com o meio ambiente. No caso da mobilidade, essa equação terá melhor resultado quanto menor for a necessidade de locomoção da casa para o trabalho. Então, se o objetivo é investir na sustentabilidade urbana, deve-se morar perto do trabalho ou trabalhar perto de casa.

Outro defensor dos grandes aglomerados urbanos é o economista americano Edward L. Glaeser, professor da Universidade de Harvard. Ele considera as cidades a maior invenção de nossa espécie, porque elas são "os motores de inovação" (GLAESER, 2011, p. 1) que impulsionam a história humana. Essa característica das cidades é atribuída pelo autor à capacidade que elas possuem de conectar as pessoas.

O autor é contrário à visão negativa de alguns ambientalistas e urbanistas sobre a vida nas grandes cidades, que os levam a algumas tentativas equivocadas de conter 0 crescimento vertical das cidades, acreditando que as pessoas isoladas uma das outras, rodeadas de árvores, viveriam melhor.

Por promover "proximidade, densidade e intimidade" (GLAESER, 2011, p. 6), a vida nas cidades aumenta as possiblidades de colaboração humana. E é nela que Glaeser entende residir "a força [...], a verdade central por trás do sucesso da civilização e o principal motivo da existência de cidades" (GLAESER, 2011, p. 16). 
Apesar de sublinhar os benefícios da vida nas cidades, ele reconhece que 0 adensamento provoca custos como, por exemplo, grandes congestionamentos, expansão de doenças e do crime. Então, para tornar o crescimento urbano mais "palatável" (GLAESER, 2011, p. 91) e combater o que chama de demônios trazidos pelo adensamento, Glaeser ressalta a necessidade de uma mão mais forte do poder público na condução de suas políticas, assim como a necessidade de serem feitos grandes investimentos nas cidades. O autor lembra os bilhões gastos pelos países mais ricos nos últimos três séculos e alerta que esse esforço deverá ser feito nas cidades dos países em desenvolvimento, onde, como já dito anteriormente, reunir-se-á, nas próximas décadas, a maior parte da população mundial.

A pobreza urbana, entretanto, não é vista por Glaeser como mais uma consequência negativa da vida nas cidades, mas, ao contrário, como um claro sinal do dinamismo urbano. "As cidades não estão repletas de pessoas pobres por tornarem as pessoas pobres, mas porque as cidades atraem pessoas pobres com a perspectiva de melhorar sua(s) vida(s)" (GLAESER, 2011, p. 70).

Ao enxergar na pobreza uma força urbana, o autor não desconsidera as dificuldades de quem a vive, afinal, como ele diz, nenhuma forma de pobreza é bonita, a urbana inclusive. Para enfrentá-la, Glaeser diz que é preciso investir nos pobres, no capital humano. E como fazer isso? Assim como Darcy Ribeiro e Brizola pensaram, no início da década de 1980, com a criação dos CIEPS no Rio de Janeiro, o autor considera que oferecer educação de qualidade para crianças pobres poder ser a melhor maneira de reverter a situação de pobreza. A educação acena não apenas com um horizonte econômico mais promissor, como também produz e consolida uma sociedade mais justa e democrática (GLAESER, 2011).

Em seu livro Os Centros Urbanos: a maior invenção da humanidade, Glaeser (2011) analisa algumas cidades de países em desenvolvimento, entre elas Mumbai e Rio de Janeiro. Nas duas, ele avalia a situação das favelas.

A favela de Dharavi, em Mumbai, é descrita como "uma massa de humanidade e empreendedorismo (GLAESER, 2011, p. 92). No local, em uma área de aproximadamente 212 hectares, ele explica que vivem entre 600 mil a 1 milhão de pessoas. Apesar dos graves problemas que enfrentam, como sistema de saneamento deficitário e alto índice de doenças, entre as quais a tuberculose, essas pessoas trabalham "duro e se beneficiam da proximidade com os consumidores urbanos e com os insumos (GLAESER, 2011, p. 92)". O autor sublinha a capacidade dos moradores de criar, nesse ambiente, um ambiente colaborativo, com pequenas confecções de roupas e usinas de reciclagem capazes de 
aproveitar caixas de cartolina usadas para refazê-las pelo avesso, de forma a deixar a parte impressa para dentro. Eles produzem, também, panelas de barro, a partir de argila de ruas não pavimentadas, e fazem triagem de produtos usados constituídos de plástico.

Em relação às favelas cariocas, Glaeser (2011) diz que elas são um exemplo de como a presença da pobreza pode revelar a força urbana. $O$ adensamento das favelas na cidade é resultado, em seu entender, da atração que ela oferece, acenando com a possibilidade de uma vida melhor, em relação à realidade enfrentada pela pobreza rural no Brasil. As migrações do campo para a cidade se traduzem para aqueles que migram em esperança, esperança por mudança no status quo. E mudança gera oportunidades, explica o autor. Essa conclusão remete à noção de desenvolvimento de Amartya Sem (2004), como ampliação das oportunidades sociais.

Assim como em Mumbai, as favelas pacificadas no Rio de Janeiro estão sendo considerados celeiros de novos negócios (SEBRAE, 2014). "Com o retorno da presença do poder público a essas regiões e a garantia do direito de ir e vir a toda a população do entorno, aumenta a quantidade de clientes potenciais, cresce a fiscalização e a necessidade de formalização dos empreendedores, uma vez que possibilita a expansão dos negócios, que nessas comunidades são, caracteristicamente, microempreendimentos" (IETS, 2012).

As questões levantadas por esses autores contribuem para a nossa reflexão sobre a oportunidade que o Rio de Janeiro está tendo, nesse momento, de tornar-se uma cidade mais sustentável. Desde Wirth (1967), com seu conceito de cidade como mosaico de mundos sociais diferentes, passando por Leite e Awad (2012), Jacobs (2000) e Lerner (2015), percebe-se os benefícios oferecidos pela sociodiversidade nas cidades. Entre eles, podemos destacar a maior segmentação de papéis sociais, úteis para atender demandas cada vez mais diferenciadas do ambiente urbano. No entanto, os resultados positivos dessa diversidade social, propiciada pela densidade populacional das cidades, serão tão maiores quanto mais fortes forem as interações entre seus habitantes Por meio dessas interações, as cidades se reinventam, tornam-se propulsoras da inovação e do desenvolvimento.

Nesse contexto, ao pensarmos nas favelas cariocas, vemos o quão são equivocados os argumentos que por anos sustentaram as políticas de remoção responsáveis pela transferência de muitos de seus habitantes para as periferias. Elas diminuem a presença da sociodiversidade no mesmo espaço urbano, ao excluir o convívio de pessoas de origens sociais diferentes. Além disso, a remoção dos mais pobres para as periferias agrava a questão da mobilidade, outro fator importante quando pensamos na equação da sustentabilidade urbana. Longe de seus locais de trabalho, essas pessoas levarão mais tempo no deslocamento casa trabalho, agravando, assim, os congestionamentos. Ademais, 
como vimos no capítulo 2, ao mudarem para outros locais, elas se desconectarão de suas redes sociais antigas, perdendo a possibilidade de lançar mão do capital social nelas existente para tornar melhor a qualidade de suas vidas.

Ao defendermos a permanência das favelas em seus locais de origem, no entanto, não estamos fechando os olhos para as dificuldades vividas por seus moradores. $O$ combate às condições de pobreza, assim como a todas as formas de exclusão, sejam elas social, econômica ou espacial constitui-se em ponto fundamental de qualquer agenda que pretenda discutir o desenvolvimento sustentável urbano. Leite e Awad (2012) e Glaeser (2011) nos chamam a atenção para a importância de se direcionar os investimentos públicos para os pobres urbanos. Mais uma vez, ao pensarmos sobre as favelas, sabemos que elas podem não ser os únicos locais onde existe pobreza na cidade, mas certamente é um dos locais onde ela se concentra em seus mais diversos aspectos.

Para contribuir para a sustentabilidade urbana da cidade, os investimentos públicos nesses locais devem se voltar não apenas às obras de infraestrutura, mas ao fortalecimento dos direitos civis, que garantam as liberdades individuais, entre elas o direito à vida, o direito de ir e vir, e o direito dos moradores serem tratados perante às leis da mesma forma que os outros habitantes da cidade. A garantia desses direitos fortalece o capital humano e social existente nas favelas, possibilitando novas oportunidades de desenvolvimento local. 


\section{EMPREENDEDORISMO NAS FAVELAS CARIOCAS}

Segundo pesquisa realizada pelo Instituto Data Favela para o Serviço Brasileiro de Apoio às Micro e Pequenas Empresas (Sebrae) e apresentada no 2 ํ Fórum Nova Favela Brasileira, em março de 2015, em São Paulo, quatro em cada dez moradores das favelas brasileiras querem empreender. Entre esses, 55\% pretendem abrir um negócio próprio dentro dos próximos três anos. Para o levantamento, realizado em fevereiro de 2015, foram ouvidas duas mil pessoas em 63 favelas de todas as regiões do Brasil (FÓRUM NOVA FAVELA BRASILEIRA, 2015) O empreendedorismo nas favelas, como veremos a seguir, constitui-se em oportunidade de trabalho e renda para quem tem dificuldade de se inserir no mercado de trabalho, como as pessoas com baixa escolaridade e, também, as mulheres. Dessa forma, o empreendedorismo pode ser considerado uma importante ferramenta no combate à pobreza, questão ainda não resolvida apesar dos esforços empreendidos nos últimos anos. A atual política de pacificação das UPPs tem demonstrado, onde ela está mais consolidada, que pode trazer benefícios ao ambiente de negócios e assim possibilitar mais desenvolvimento para as favelas.

\subsection{UMA OPORTUNIDADE PARA QUEM TEM BAIXA ESCOLARIDADE}

A média de anos de estudo da população ocupada em favelas, no Rio de Janeiro, em 2007-2008, era de 6,38 anos, enquanto a da cidade como um todo era de 9,89 anos. Essa diferença contribui para a compreensão da persistência das desigualdades sociais (NERI, 2010)

A Rocinha, por exemplo, ilustra bem essa situação. Considerada a maior favela do país, é a região administrativa da cidade com o menor nível de educação (RIO DE JANEIRO (Prefeitura), 2000). De acordo com o Índice de Desenvolvimento Humano dos bairros da cidade do Rio de Janeiro, em 2000, a escolaridade média da Rocinha era de 4,9 anos (RIO DE JANEIRO (Prefeitura), 2004). Sua taxa de alfabetização de adultos é a menor entre os bairros (87,90\%). Seu IDHM, no ano 2000 , era de 0,732 , o $120^{\circ}$ colocado entre 126 bairros ou grupos de bairros na cidade do Rio de Janeiro. O Quadro 3, com indicadores sociais e econômicos, apresenta o grande contraste existente entre alguns bairros e comunidades do Rio de Janeiro. 
Quadro 3 - Indicadores sociais e econômicos por bairros e comunidades selecionadas da cidade do

Rio de Janeiro - 2000.

\begin{tabular}{|c|c|c|c|c|c|c|c|c|}
\hline $\begin{array}{l}\text { Ordem } \\
\text { segundo } \\
\text { o IDH }\end{array}$ & $\begin{array}{l}\text { Bairro ou } \\
\text { grupo de } \\
\text { bairros }\end{array}$ & $\begin{array}{c}\text { Esperança } \\
\text { de vida ao } \\
\text { nascer } \\
\text { (em anos) }\end{array}$ & $\begin{array}{c}\text { Taxa de } \\
\text { alfabetização } \\
\text { de adultos (\%) }\end{array}$ & $\begin{array}{c}\text { Taxa bruta } \\
\text { de } \\
\text { frequência } \\
\text { escolar (\%) }\end{array}$ & $\begin{array}{l}\text { Índice de } \\
\text { longevidade } \\
\text { (IDH-L) }\end{array}$ & $\begin{array}{c}\text { Índice de } \\
\text { educação } \\
\text { (IDH-E) }\end{array}$ & $\begin{array}{l}\text { Índice de } \\
\text { renda } \\
\text { (IDH-R) }\end{array}$ & IDH \\
\hline 1 & Gávea & 80.45 & 98.08 & 118.13 & 0.924 & 0.987 & 1.000 & 0.970 \\
\hline 2 & Leblon & 79.47 & 99.01 & 105.18 & 0.908 & 0.993 & 1.000 & 0.967 \\
\hline 3 & $\begin{array}{l}\text { Jardim } \\
\text { Guanabara }\end{array}$ & 80.47 & 98.92 & 111.15 & 0.924 & 0.993 & 0.972 & 0.963 \\
\hline 4 & Ipanema & 78.68 & 98.78 & 107.98 & 0.895 & 0.992 & 1.000 & 0.962 \\
\hline 5 & Lagoa & 77.91 & 99.46 & 115.26 & 0.882 & 0.996 & 1.000 & 0.959 \\
\hline 6 & Flamengo & 77.91 & 99.28 & 119.08 & 0.882 & 0.995 & 1.000 & 0.959 \\
\hline 7 & Humaitá & 77.91 & 99.28 & 122.20 & 0.882 & 0.995 & 1.000 & 0.959 \\
\hline 8 & $\begin{array}{l}\text { Joá, Barra } \\
\text { da Tijuca }\end{array}$ & 77.84 & 99.38 & 110.09 & 0.881 & 0.996 & 1.000 & 0.959 \\
\hline 120 & Rocinha & 67.33 & 87.90 & 69.50 & 0.706 & 0.818 & 0.673 & 0.732 \\
\hline 121 & Jacarezinho & 66.30 & 92.20 & 75.68 & 0.688 & 0.867 & 0.638 & 0.731 \\
\hline 122 & Manguinhos & 66.30 & 91.48 & 69.64 & 0.688 & 0.842 & 0.648 & 0.726 \\
\hline 123 & Maré & 66.58 & 89.46 & 68.76 & 0.693 & 0.826 & 0.646 & 0.722 \\
\hline 124 & $\begin{array}{l}\text { Acari, } \\
\text { Parque } \\
\text { Colúmbia }\end{array}$ & 63.93 & 91.68 & 79.44 & 0.649 & 0.876 & 0.634 & 0.720 \\
\hline 125 & $\begin{array}{l}\text { Costa } \\
\text { Barros }\end{array}$ & 63.93 & 91.34 & 74.09 & 0.649 & 0.856 & 0.635 & 0.713 \\
\hline 126 & $\begin{array}{l}\text { Complexo } \\
\text { do Alemão }\end{array}$ & 64.79 & 89.07 & 72.04 & 0.663 & 0.834 & 0.637 & 0.711 \\
\hline
\end{tabular}

Fonte: RIO DE JANEIRO (Prefeitura /IPP) - 2000.

Entre os piores bairros representados, a Rocinha ficou à frente apenas dos bairros Jacarezinho, Manguinhos, Maré, Acari/Parque Colúmbia, Costa Barros, Complexo do Alemão. Três deles, o Complexo do Alemão, o Complexo da Maré (ou simplesmente Maré) ${ }^{15}$ e o Jacarezinho, assim como a própria Rocinha, são regiões de favelas densamente povoadas, transformadas em regiões administrativas na década de 1980 para facilitar a atuação do poder público (CAVALLIERI; VIAL, 2012).

Localizada na zona sul do Rio de Janeiro, a Rocinha estende-se pelo Morro Dois Irmãos, que separa dois bairros de classe média alta da cidade: Gávea e São Conrado. A

${ }^{15} \mathrm{O}$ Complexo da Maré, formado por um conjunto de comunidades, deu origem ao bairro da Maré, criado a partir da Lei № 2119, de 19 de janeiro de 1994. 
Gávea possui o maior IDHM da cidade 0,970. A presença contrastante dessa favela na paisagem urbana, portanto, pode ser considerada um ícone da desigualdade social no país.

Pesquisa sobre microempreendedorismo em favelas com UPP, realizada pelo Instituto de Estudos do Trabalho e Sociedade (IETS) e Sebrae $\left(2012^{b}\right)$, baseada em dados do PNAD/IBGE 2012, confirma a carência educacional dessas áreas, mostrando que a taxa de analfabetismo em favelas com UPP é de $7 \%$ e que a de analfabetismo funcional é 19\%. Revela, ainda, que a maioria dos microempreendedores dessas áreas não conseguiu completar o ensino fundamental (53\%). A escolaridade média é de 6,8 anos, mesmo valor apontado por Neri (2010) para a escolaridade média do carioca ocupado residente de aglomerado subnormal em 2007-2008. Esses resultados nos mostram que de 2008, data da implantação da primeira UPP no Rio de janeiro, até 2012, a escolaridade média dos moradores de favelas pacificadas não havia sofrido alterações.

\subsection{UMA OPORTUNIDADE PARA AS MULHERES}

A pesquisa realizada pelo Instituto Data Favela para o Sebrae (FÓRUM NOVA FAVELA BRASILEIRA, 2015) mostrou, ainda, que as mulheres constituem a maioria dos que querem empreender nas favelas (51\%). Além disso, revelou que $63 \%$ dos futuros empreendedores desejam empreender dentro das favelas. Ter um empreendimento significa mais do que um aumento da renda. De acordo com Luiz Barreto, presidente do Sebrae, responsável pela divulgação da pesquisa no $2^{\circ}$ Fórum Nova Favela Brasileira, muitas mulheres empreendedoras, moradoras de favelas, são motivadas pela possibilidade de trabalhar em horários flexíveis, para conciliar as demandas do trabalho com as da família (FORTUNA, 2015).

A presença da mulher mais próxima dos filhos pode ser considerada um fator importante na prevenção do envolvimento dos jovens com atividades criminosas violentas. No país, como é mostrado na Figura 9, verifica-se uma alta concentração de homicídios entre os jovens. Nos grandes centros urbanos brasileiros, esses jovens são predominantemente negros, pobres e residentes de favelas e bairros pobres das periferias (RAMOS; LEMGRUBER, 2004).

Na faixa etária dos 15 aos 24 anos, as taxas (de vítimas de homicídios) são extraordinariamente mais altas do que as verificadas para a população como um todo. A tendência [...] é nacional, ocorrendo mesmo nos estados com taxas mais baixas de violência letal. Quando examinamos algumas áreas urbanas pobres, focalizando os jovens, encontramos taxas de mais de 200 homicídios dolosos por 100 mil habitantes. (RAMOS; LEMGRUBER, 2004, p. 46). 


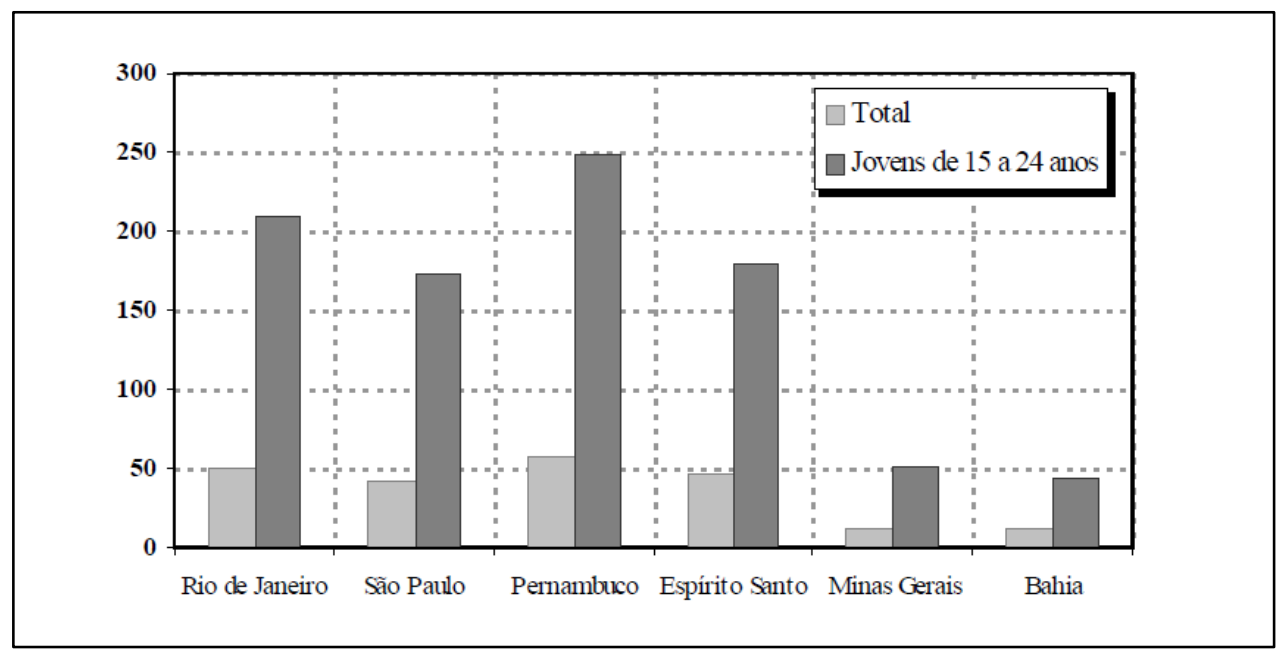

Figura 9 - Taxa de homicídios por 100 mil habitantes em alguns estados brasileiros: jovens e total - 2001.

Fonte: Ramos; Lemgruber, 2004 (com base no Sistema de Informação sobre Mortalidade - Datasus).

A pesquisa realizada pelo Instituto Data Favela revela, ainda, que as mulheres, além de representarem a maioria entre os futuros empreendedores, já são o principal grupo que possui negócios nas favelas.

O estudo do IETS/Sebrae $\left(2012^{b}\right)$ mostra, também, que a maioria dos empreendimentos em territórios do Rio de Janeiro com UPPs é constituída por mulheres (57\% dos trabalhadores por conta própria). A pesquisa aponta, ainda, que a maioria dos empreendedores (mulheres e homens) atua por conta própria (91\%), tem em média 43 anos e inicia seus negócios movidos pela necessidade. A necessidade é explicada tanto por uma situação de desemprego (30\%), como pela busca por aumento na renda (18\%).

O trabalho por conta própria das mulheres é muito importante não só para elas, como para suas famílias, principalmente tratando-se de famílias pobres. Dados do Censo 2010 do IBGE mostram, por exemplo, que, na Rocinha, as mulheres são responsáveis por quase metade dos domicílios (47\%) e na Santa Marta essa proporção é ainda maior (55\%) (Figura 10). 


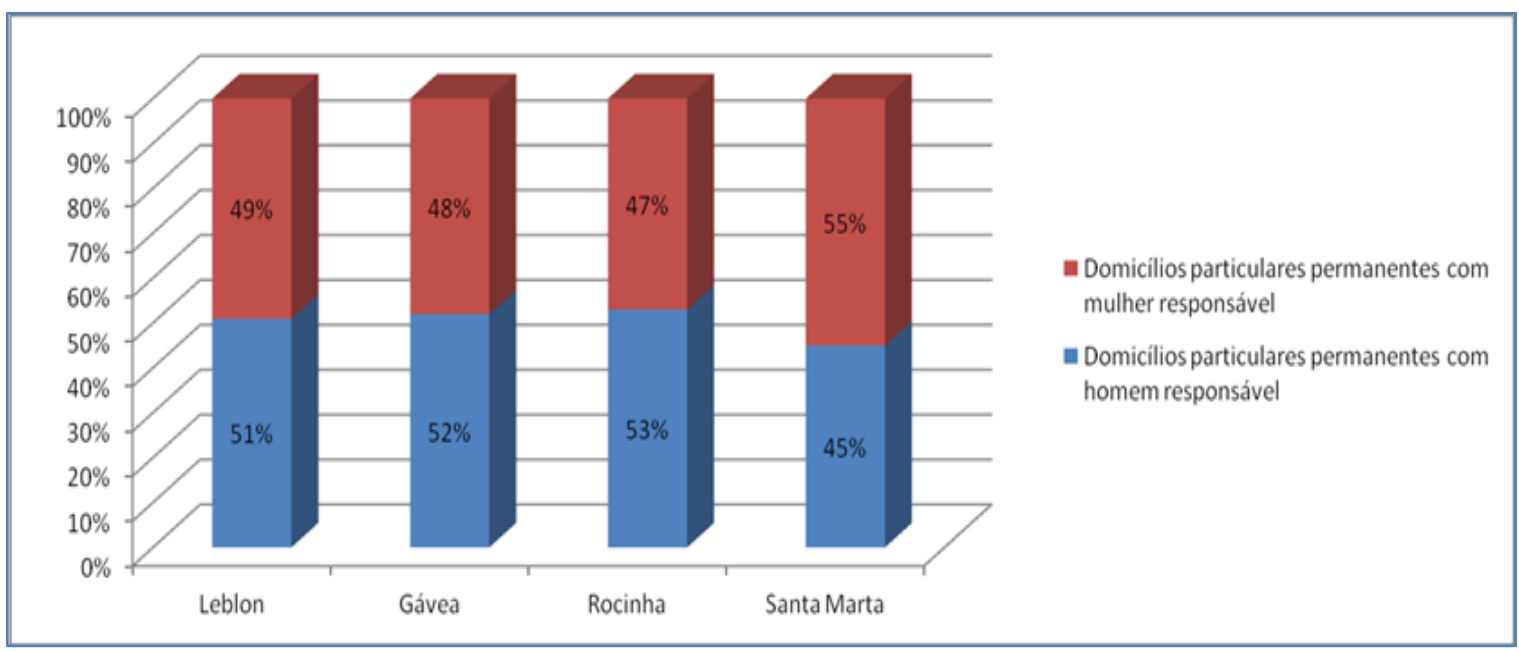

Figura 10 - Proporção de mulheres e homens responsáveis por domicílios permanentes.

Fonte: Dados do IBGE/ Censo 2010, elaborado pela autora.

Dados do Censo de 2010 do IBGE revelam, ainda, que no Rio de Janeiro 46,5\% dos domicílios são chefiados por mulheres e que $24 \%$ delas ganham menos do que um salário mínimo. A média brasileira de lares chefiados por mulheres é de 37,3\% e em áreas urbanas essa média sobre para 39,3\% (IBGE, 2014). As chefes de família cariocas representam um percentual maior em relação a essas médias e, também, em relação às outras médias das capitais do Sudeste. Em São Paulo, a média dos lares chefiados por mulheres é de 44,1\%, em Vitória, 43,9\%, e em Belo Horizonte, 43,5\%.

As condições de vida dessas famílias tornam-se, certamente, ainda mais difícil quando as mulheres assumem a responsabilidade por todo o cuidado com suas famílias não apenas financeiramente. Dados do Sistema Nacional de Informações de Gênero (SNIG) do IBGE, baseados nos resultados do Censo Demográfico de 2010, mostram que as mulheres são maioria (87\%) na condição de responsável por famílias monoparentais, com filhos (IBGE, 2014, p. 65). Essas famílias sustentadas por mulheres sozinhas enfrentam outro desafio: a forte desigualdade de gênero existente no mercado de trabalho brasileiro. Como demonstra pesquisa do IPEA (2012), no Brasil, as mulheres ganham menos dos que os homens e são maioria entre os desempregados (Figuras 10 e 11). Tal situação tende, assim, a agravar ainda mais a realidade das mulheres pobres chefes de família, sem cônjuges. 


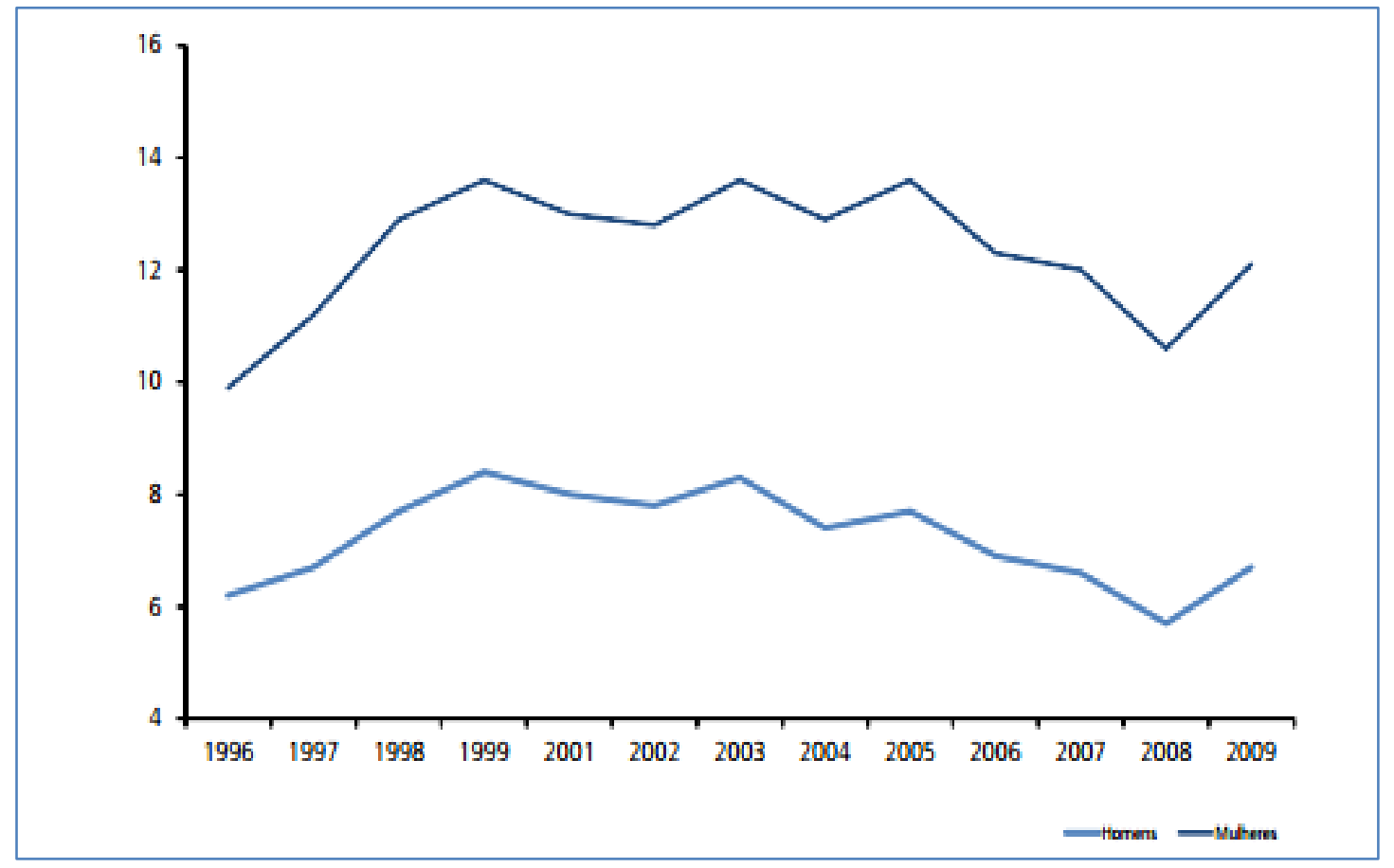

Figura 11 - Taxa de desemprego entre homens e mulheres (em \%).

Fonte: Ipea 2012. Mercado de trabalho conjuntura e análise / Instituto de Pesquisa Econômica Aplicada; Ministério do Trabalho e Emprego - ano 17, fev. 2012 - Brasília: Ipea: MTE.

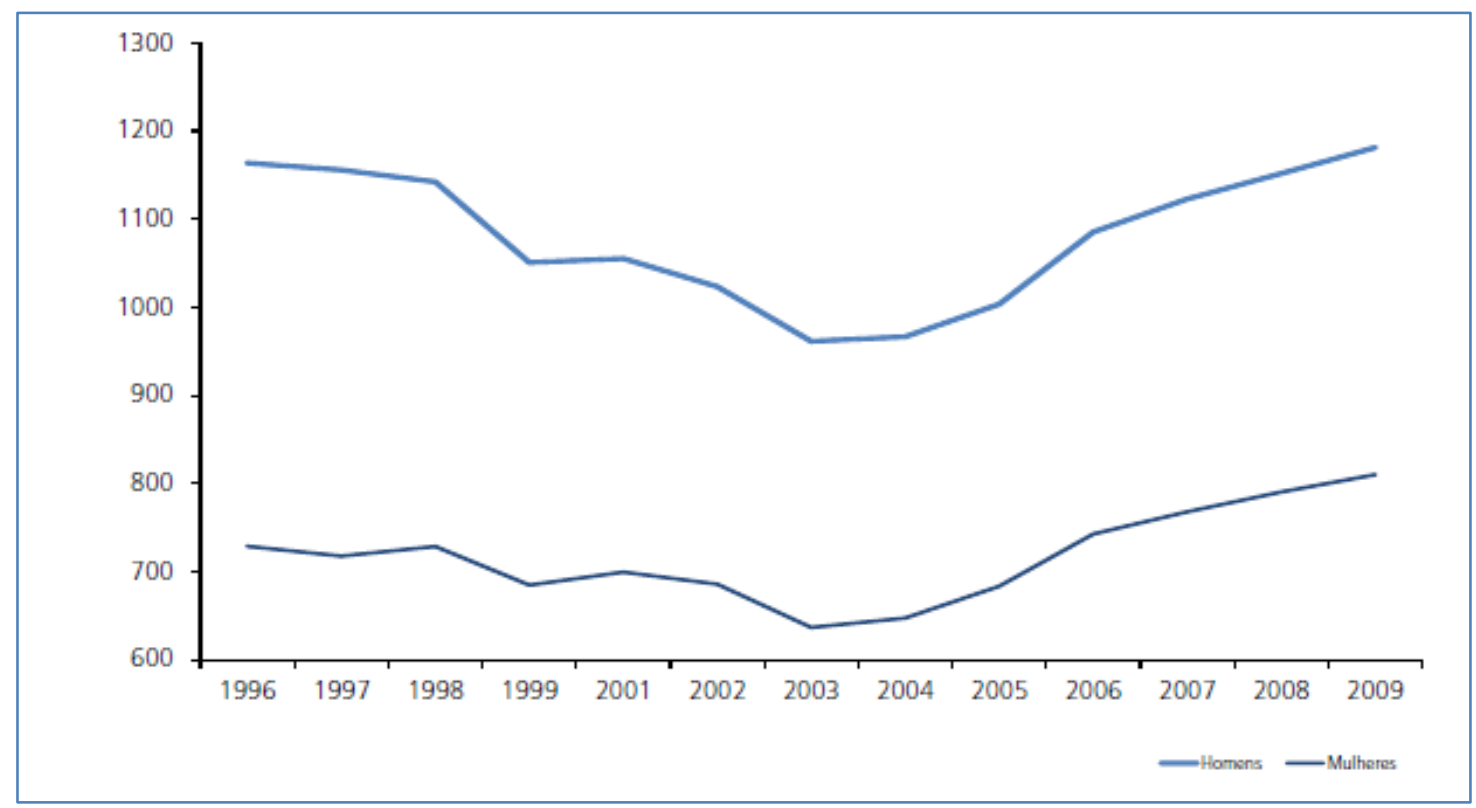

Figura 12 - Rendimento homens/mulheres (em R\$).

Fonte: Ipea, 2012. Mercado de trabalho conjuntura e análise / Instituto de Pesquisa Econômica Aplicada; Ministério do Trabalho e Emprego - ano 17, fev. 2012 - Brasília: Ipea: MTE.

Uma outra pesquisa realizada pelo Dieese, a pedido do jornal O Globo, revela que, em 2012, entre as pessoas que estavam desempregadas há mais de um ano, 63,2\% eram mulheres e 60,6,3\% eram negros. Na reportagem que traz a divulgação do trabalho, a economista do Diese Lúcia Garcia explica que a situação dessas pessoas é difícil de mudar, 
independentemente de a taxa de desemprego no país melhorar ou não (PAULA; SPITZ, O Globo, 10/8/2013, p. 21). "É como uma piscina com um fluxo de entrada e saída. Tem gente sempre ficando no fundo e, quanto mais tempo a pessoa fica desempregada, mais tempo ela tende a ficar desempregada" (Lúcia Garcia, depoimento para o jornal O Globo, 2013).

Quando o desemprego cai, as oportunidades são preenchidas primeiro por homens brancos. É nesse momento que as desigualdades entre gêneros e cor de pele tornam-se mais evidentes.

\subsection{CRISE ECONÔMICA DESAFIA SUPERAÇÃO À POBREZA}

O Brasil destacou-se internacionalmente, nos últimos anos, por ter conseguido uma grande redução da pobreza. De acordo com o relatório do Banco Mundial "Prosperidade

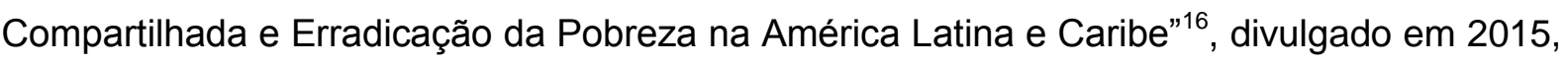
o percentual da população brasileira vivendo em extrema pobreza caiu de $10 \%$ para $4 \%$, entre 2001 e 2013.

No entanto, nos últimos anos, o Brasil, assim como outros países da América Latina, vem sendo pressionado por um novo cenário econômico nacional e internacional desfavorável, marcado, entre outros fatores, pela queda do preço das commodities e pela desaceleração do crescimento da China. Assim, enfrenta o desafio de manter suas conquistas sociais em meio à recessão econômica e à redução da renda per capita.

A queda do PIB brasileiro, em 2015, e as previsões de ritmo semelhante em 2016, a volta da inflação e a desvalorização do real sinalizam previsão de aumento da pobreza. A ameaça não paira apenas sobre o país. Em recente relatório sobre o desenvolvimento social, a Cepal (2015) faz um apelo a todas as nações da América Latina e Caribe, considerada a região mais desigual do planeta, em prol do combate à pobreza e à desigualdade social.

Embora reconheça que esses países tenham tido, na última década, grandes avanços em relação ao desenvolvimento social, a Cepal sublinha que a redução da desigualdade e superação da pobreza extrema são desafios importantes que precisam ser enfrentados. Ambos constituem, ainda, objetivos que fazem parte da Agenda 2010 para o desenvolvimento sustentável global, acordada pelos países-membros da ONU em 2015.

16 Disponível em: <https://nacoesunidas.org/relatorio-banco-mundial-afirma-que-brasil-conseguiupraticamente-erradicar-extrema-pobreza/>. Acesso 15/11/2015. 
Levantamento do IETS ${ }^{17}$, com base no PNAD 2014 do IBGE, mostra que a porcentagem da pobreza, no Brasil, diminuiu de $37,5 \%$ para $15,8 \%$ de 2004 a 2014 . Na região metropolitana do Rio de Janeiro, essa redução foi de $26,7 \%$ para $11,1 \%$, e a redução da extrema pobreza foi de $8,8 \%$ para $2,3 \%$.

Outro índice que melhorou foi a renda. O mesmo levantamento mostra que, no período entre 2004 e 2014, a renda aumentou de $R \$ 980,70$ para $R \$ 1.382,30$ na região metropolitana do Rio de Janeiro.

Políticas públicas voltadas para a redução de desigualdades sociais, incluindo Bolsa Família, aumento real do salário mínimo e disseminação do crédito, contribuíram para amenizar os efeitos da pobreza nesse período. Entretanto, o Banco Mundial diz que a melhoria das oportunidades de ganhos requer "uma mistura criativa de serviços de emprego, treinamento, apoio ao trabalho autônomo e empreendedorismo, além de acesso ao crédito" (BANCO MUNDIAL, 2013 ${ }^{\text {b }, ~ p . ~ 15) . ~}$

\subsection{A FORÇA ECONÔMICA DO EMPREENDEDORISMO NAS FAVELAS}

O empreendedorismo tem mostrado ser uma força econômica importante nas favelas cariocas. O Complexo da Maré, por exemplo, reúne 16 comunidades ao longo da Avenida Brasil e, em 2013, contabilizava 3.182 empreendimentos. De acordo com metodologia adotada pela Prefeitura do Rio de Janeiro, que considera os complexos de favelas como unidades, o da Maré é considerado a segunda maior favela da cidade, atrás apenas da Rocinha (Tabela 3).

Tabela 3 - Dez maiores favelas da cidade - Município do Rio de Janeiro - 2010.

\begin{tabular}{l|l|c|c}
\hline \multicolumn{1}{c|}{ Favelas } & Regiöes Admistrativas & $\begin{array}{c}\text { Areas de } \\
\text { Planejamento }\end{array}$ & $\begin{array}{c}\text { População IPP } \\
2010\end{array}$ \\
\hline Rocinha & Rocinha & 2 & 69.161 \\
Complexo da Maré & Complexo da Maré & 3 & 64.094 \\
Complexo de Rio das Pedras & Jacarepaguá & 4 & 63.484 \\
Complexo do Alemão & Complexo do Alemão & 3 & 60.583 \\
Complexo da Fazenda Coqueiro & Bangu & 5 & 45.415 \\
Complexo da Penha (Vila Cruzeiro) & Penha & 3 & 36.862 \\
Complexo do Jacarezinho & Jacarezinho & 3 & 34.603 \\
Complexo de Acari & Pavuna & 3 & 21.999 \\
Complexo de Vigário/ Lucas & Vigário Geral & 3 & 20.570 \\
Complexo do Bairro da Pedreira & Pavuna & 3 & 20.515 \\
\hline
\end{tabular}

Fonte: RIO DE JANEIRO (Prefeitura), 2012.

O número de empreendimentos foi divulgado pelo Censo de Empreendimentos da Maré (2014), lançado pela Redes de Desenvolvimento da Maré em parceria com o

\footnotetext{
${ }^{17}$ Fonte: http://www.iets.org.br/dado/parametros-e-resultados-da-pnad-2014.
} 
Observatório das Favelas. A publicação baseou-se na realização do primeiro censo de empreendimentos econômicos realizado na região e teve como objetivo mapear o perfil econômico do local. Ao todo, foram pesquisadas 2.953 unidades comerciais ou atividades empreendedoras individuais.

No processo decisório sobre que tipo de empreendimento deveria ser incluído, não houve restrição aos empreendimentos informais, que constituem a maior parte das unidades. O que ficou de fora do levantamento foi o comércio de produtos ou serviços ilícitos, como roupas, tênis, CDs, e a distribuição de sinal de TV.

Em relação aos locais onde as atividades econômicas são exercidas, não houve restrição à inclusão daquelas realizadas nas próprias residências. De acordo com o Censo, foi verificado que é comum as atividades serem desempenhadas no próprio domicílio.

No entanto, elas foram distinguidas em dois grupos: unidades comerciais e atividades empreendedoras individuais. As primeiras funcionam em espaço exclusivo de uso comercial para o público, que pode ser até no próprio domicílio do empreendedor, contanto que tenha um espaço adaptado ou reservado para a realização do trabalho. Já as atividades de empreendedorismo individual são desenvolvidas pelos empreendedores em suas próprias casas, sem que haja para isso um lugar específico. É importante ressaltar que, neste último caso, só foram incluídas no Censo as atividades empreendedoras individuais que podiam ser identificadas na rua, seja por meio de letreiro, pintura da fachada ou de outra forma.

Em nossas visitas de campo, conhecemos empreendedores individuais, como as do grupo "Costurando Ideais", na favela Santa Marta, que desenvolvem suas atividades na sala da casa de uma das costureiras. O local, embora tenha se tornado de trabalho, é também o cômodo pelo qual todos os moradores, necessariamente, transitam para entrar e sair da casa. Além disso, não pode ser identificado por quem passa na rua em frente como um local de trabalho. Essa observação nos leva a pensar que o número de empreendedores individuais no Complexo da Maré possa ser ainda maior, pois deve haver muitos empreendedores que desenvolvem suas atividades como o grupo "Costurando Ideiais" e, portanto, não foram contabilizados no Censo. Da mesma forma será em qualquer outra favela, se for adotada a mesma metodologia do Censo de Empreendedores da Maré.

Além do comércio de bens e serviços para o consumo local, o empreendedorismo tem um significado importante para essas comunidades. O Censo da Maré destaca que ele movimenta um mercado socialmente necessário, gerando trabalho e renda para os moradores.

Com a política de pacificação das favelas do Rio de Janeiro, esse mercado tem atraído a atenção de formuladores de políticas, empresários e instituições como Sebrae e 
Firjan. Em outubro de 2013, a Cidadania Empresarial e a UPP foi tema do 5 Seminário Oportunidades do Rio, realizado na cidade. O evento foi promovido pelo jornal O Globo, em parceria com o Sebrae-RJ e com o apoio do IETS. Na ocasião, Cezar Vasquez, diretor superintendente do Sebrae-RJ, destacou que a abertura de acesso a regiões antes isoladas da cidade foi um dos grandes efeitos da pacificação.

A pacificação permitiu ao Sebrae entrar em lugares do Rio do Janeiro, fazer coisas que tinha como missão e antes simplesmente não conseguia fazer. Não dá para medir o quanto isso foi importante. Essa mudança de ambiente fez com que 0 microempreendedorismo passasse a buscar mais formalização, mais acesso a crédito e maior capacitação. (PAULA, 2013, p. 45).

Outro palestrante que sublinhou os efeitos da pacificação quanto à possibilidade de maior conexão da cidade com essas áreas e vice-versa foi Manuel Thedim, diretor do IETS. Em sua opinião, "o que a [...] UPP mais deu para a essa garotada foi a possibilidade de circulação, de receber gente de fora em casa" (PAULA, 2013, p. 45).

Os empreendedores do Complexo da Maré reconhecem, também, a importância da segurança para o desenvolvimento da economia local. Ao serem indagados sobre as condições que seriam propulsoras deste desenvolvimento, os entrevistados pelo Censo de Empreendedorismo foram direto ao ponto. Mais segurança, redução da violência e fim do tráfico de drogas foram a segunda maior reivindicação dos empreendedores, atrás apenas da reivindicação por mais agências bancárias ou postos de atendimento eletrônico.

A respeito das condições que possam estimular o desenvolvimento da economia local, os empreendedores destacaram, ainda, questões relacionadas à qualidade de vida, tais como saúde e educação. A pesquisa conclui que essa preocupação deve-se ao fato de a maioria dos entrevistados residir na Maré e, por isso, valorizar

os empreendimentos, em grande medida, como uma oportunidade de trabalho no local em que vivem, e não exatamente como uma empresa cuja eventual expansão poderia lhes oferecer um padrão de vida mais alto em outro bairro da cidade. (CENSO DE EMPREENDIMENTOS DA MARÉ, 2014, p. 66).

A integração trabalho e moradia têm, portanto, um peso no significado de desenvolvimento local para essas pessoas. Nossa hipótese de pesquisa é que a política de pacificação, se consolidada, pode contribuir nesse sentido, criando condições para que os empreendimentos se desenvolvam nas residências ou próximos a elas.

Outra grande favela carioca, onde, também, foi feito um levantamento dos empreendimentos existentes, é a Rocinha, considerada "a favela campeã em empreendedores" (MEIRELLES; ATHAYDE, 2014, p. 73). Esse levantamento, que resultou no Censo Empresarial da Rocinha (2010), será comentado no capítulo 6, onde abordaremos a situação de alguns empreendedorismos na Rocinha e na Santa Marta. 
Com base em tabulações especiais da PNAD/IBGE - 2006, realizadas pelo IETS, Urani (2008), ao avaliar a proporção de famílias chefiadas por empreendedores nas diferentes camadas sociais, conclui que o empreendedorismo carioca pode, em grande parte, ser considerado um empreendedorismo de subsistência. A maioria dos "empreendedores cariocas são pequenos comerciantes e prestadores de serviços que se estabelecem, na informalidade e sem acesso algum a serviços produtivos, nas favelas da cidade" (URANI, 2008, p. 61).

Urani (2008) acredita na importância do empreendedorismo no combate à pobreza, no entanto, frisa ser necessário que o ambiente de negócios para as micro e pequenas empresas precisa melhorar. Ele explica que quase $3 / 4$ dos chefes de família indigentes e metade dos pobres que trabalham são trabalhadores por conta própria ou empregados sem carteira de trabalho assinada.

Apesar da redução da pobreza de 38,3\%, verificada no Brasil entre 1992 e 2006, Urani (2008) assinala que, na região metropolitana do Rio de Janeiro, essa redução foi menor, de $32,5 \%$. Em 2006, 16,7\% dos cariocas, cerca de dois milhões de residentes na região metropolitana, ainda viviam abaixo da linha de pobreza (URANI, 2008, p. 55). E a taxa de desemprego era quase quatro pontos percentuais maior do que a brasileira (URANI, 2008, p. 48), sendo que, para as mulheres, essa taxa era maior do que para homens, $14,7 \%$ e $9 \%$, respectivamente.

Uma das principais razões para esse ritmo mais lento da economia carioca é atribuída ao fato de ela ter sido pouco beneficiada com a extração de petróleo e gás, na qual o estado do Rio de Janeiro apostou todas as fichas para promoção do crescimento de sua economia. Essa atividade é realizada fora da área metropolitana, tem baixo impacto sobre a empregabilidade e é mais intensiva em capital do que em mão de obra.

Nos anos seguintes, a realidade das favelas refletiu uma mudança em curso. O Data Popular, primeiro instituto de pesquisa, no Brasil, especializado em 'mercados emergentes', mostra que "em 2010 a renda somada da classe C chegava a 500 bilhões de reais, alimentando 76\% do consumo no país" (MEIRELLES; ATHAYDE, 2014, p. 53). Além disso, naquele mesmo ano, o consumo da classe $D$, que movimentou 380 bilhões de reais, superava o da classe $A$, que não passou de 260 bilhões de reais.

Para Meirelles, presidente do Data Popular, e Athayde, criador da Central Única das Favelas (CUFA), a mudança é atribuída principalmente ao trabalho. "O Brasil gerou 20 milhões de empregos em dez anos, até 2013, muitas dessas vagas (foram) ocupadas pelos habitantes das favelas" (MEIRELLES; ATHAYDE, 2014, p. 54). 
Os autores divulgam os dados da pesquisa Radiografia das Favelas Brasileiras no livro Um país chamado favela, lançado em setembro de 2014. O trabalho inaugurou os estudos do Instituto Data Favela, criado por ambos, e foi lançado no 1ํórum Nova Favela Brasileira, realizado no dia 4 de novembro de 2013.

$\mathrm{Na}$ pesquisa, realizada no segundo semestre de 2013, verificou-se que entre os moradores das comunidades que trabalhavam, 49\% tinham a carteira assinada, atestando seu vínculo com o mercado de trabalho formal; $21 \%$ estavam no mercado informal; $19 \%$ eram autônomos; 4\% eram empregadores; 3\% tinham empregos públicos; e 3\% tinham outras ocupações. Os dados indicam um contexto econômico propício ao desenvolvimento de atividades produtivas nas favelas, entre elas o empreendedorismo.

Nessa época, o número de habitantes das favelas brasileiras foi estimado em 11,7 milhões de habitantes, quantidade equivalente à população do quinto estado mais populoso do Brasil. A pesquisa constatou, ainda, que essas pessoas movimentam uma economia de 63 bilhões de reais anualmente. No dia 18 de janeiro de 2016, atualizamos esses dados diretamente com a equipe responsável pelo Data Favela. Assim, a população de favelas cresceu para 12,38 milhões de pessoas, e a renda que elas movimentam subiu para $R \$ 74,7$ bilhões.

A conclusão que salta aos olhos é que "há mais dinheiro circulando, mais do que em qualquer outro momento da história das comunidades" (MEIRELLES; ATHAYDE, 2014, p. 30). Esse dinheiro reflete o aumento da renda das famílias, que, por outro lado, foi resultado de uma série de condições favoráveis no ambiente econômico. Entre 2003 e 2013, aumentou não apenas o número de pessoas empregadas, como houve maior valorização do trabalho.

Projeção do Instituto Data Popular (MEIRELLES; ATHAYDE, 2014), com base na PNAD/IBGE 2003 e 2012 (descontada a inflação do período), mostra que, em 2003, a média salarial do favelado era de $R \$ 603,00$ e, em 2013 , saltava para $R \$ 1.068,00$. Importante ressaltar que esse ganho de $54,7 \%$ foi muito maior do que os $37,9 \%$ que representa o salto da renda média da mão de obra produtiva no país, que saiu de $R \$ 1.172,00$, em 2003, para $\mathrm{R} \$ 1.616,00$, em 2013.

Ao convertermos a evolução da renda média para valores em dólares americanos, considerando a taxa média de câmbio no ano correspondente $(R \$ 3,05$, em 2003 , e $R \$ 2,12$, em 2013), observamos um salto ainda maior da renda dos brasileiros, com uma variação de US\$ 384.00, em 2003, para US\$ 762.00, em 2013, um aumento de 98\%. Entre a população residente em favelas, essa evolução, em dólares, foi de US\$198.00, em 2003 para US\$ 504.00, em 2013, um aumento de 154\%. 
Meirelles e Athayde (2014) reconhecem, também, o papel de programas de transferência de renda, como o Bolsa Família (BF), que, apesar do pequeno valor médio do benefício, impactam sobremaneira as famílias mais pobres e contribuem para maior dinamismo da economia. Os autores ressaltam que, no final de 2013, cada real investido no programa adicionava 1,78 real ao Produto Interno Bruto brasileiro. Ao permitir que uma parcela da população passasse a consumir, o Bolsa Família impulsionou o aumento da produção e expandiu a oferta de emprego.

Além de servir como um reforço à renda e contribuir para o sustento das famílias, Meirelles e Athayde (2014) ressaltam que o programa beneficiou especialmente as mulheres. "Quem tem garantido o pão de cada dia pode se dedicar, por exemplo, a uma oficina de costura ou à preparação e venda de algum quitute" (MEIRELLES; ATHAYDE, 2014, p. 62).

Esse foi o caso de Sonia Maria de Oliveira, costureira do grupo Costurando Ideais, da favela Santa Marta. Sonia perdeu o marido de forma repentina, assassinado em Maricá, e se viu sozinha com seus dois filhos. Nessa fase, precisou contar com a ajuda do Bolsa Família para garantir o sustento dos filhos e aproveitou a oportunidade para começar a fazer o seu empreendimento. Apesar de reconhecer a importância do auxílio para quem não tem qualquer renda, com o tempo, ela abriu mão da ajuda do governo.

\footnotetext{
"A Bolsa Família deveria ser usada por quem precisava mais do que eu. $\mathrm{Na}$ época teve gente que não entendeu e veio me criticar. Mas eu achava que podia viver com o que tirava do meu trabalho". (Sonia, favela Santa Marta, depoimento, abril 2015).
}

Sonia é um exemplo de mulher empreendedora, moradora de favela, que valorizou a oportunidade de montar um negócio em casa e viver dele. Assim como ela, muitas outras pessoas vivem hoje ou complementam sua renda desenvolvendo pequenos negócios nas favelas, ilustrando a força econômica do empreendedorismo nesses locais.

\subsection{UPPS: IMPACTO NAS FAVELAS E NOS EMPREENDIMENTOS}

O Programa UPP, que comemorou sete anos em dezembro de 2015, já tem 38 unidades instaladas no Estado do Rio de Janeiro. Segundo dados oficiais do governo do estado do Rio de Janeiro, o programa já beneficia 1,5 milhão de pessoas. A presença do Estado, reforçada por investimentos de 1,8 bilhão de reais, realizados pela prefeitura da cidade, de 2009 a 2014, tem possibilitado diversas melhorias sociais (RIO DE JANEIRO (Estado), 2015 ${ }^{\mathrm{c}}$. 
$\mathrm{Na}$ área da saúde, contribuiu para a ampliação da cobertura do Programa Saúde da Família (PSF). Em 2008, apenas 3\% da população do Rio tinham acesso ao PSF, atualmente esse valor subiu para $44,2 \%$ na cidade. Nas áreas pacificadas, $73 \%$ dos moradores, hoje, têm acesso ao programa e em 12 dessas áreas a cobertura é de $100 \%$. Na área de educação, as ações da prefeitura possibilitaram a criação de 50 Espaços de Desenvolvimento Infantil, com a abertura de 9 mil vagas nessas comunidades (RIO DE JANEIRO (Prefeitura/IPP) ${ }^{\mathrm{a}}$.

Entre 2009 e 2013, o aumento do rendimento escolar dos alunos nas áreas pacificadas foi maior do que o observado no município como um todo, indicando que a violência deprimia o rendimento dos alunos nas escolas. No período, a evolução do IDEB (Índice de Desenvolvimento da Educação Básica) foi de 18\% na cidade do Rio de Janeiro, enquanto que, nas áreas pacificadas, foi de $24 \%$. A taxa leva em consideração o desempenho dos estudantes do $6^{\circ}$ ao $9^{\circ}$ ano em exames oficiais e a taxa de evasão escolar.

A presença maior do Estado com a nova política de segurança pública, somada aos resultados de programas de transferência de renda como o BF, trouxeram novos ares para esses territórios. De acordo com os depoimentos colhidos pelo Data Popular, as UPPs proporcionaram finalmente às comunidades a possibilidade de terem uma "vida sem tormentos de guerra" (MEIRELLES; ATHAYDE, 2014, p. 58).

Na pesquisa realizada pelo IETS e o Sebrae, em 2012, como pode ser observado na Figura 13, a segurança foi o fator positivo mais ressaltado pelos microempreendedores de favelas sobre o impacto das UPPs. Entre eles, 41\% dos microempreendedores empregadores e $35 \%$ daqueles que trabalham por conta própria valorizaram a maior segurança após a implantação da política de pacificação. Em seguida, os microempreendedores destacaram, também, que as UPPs impactam de forma positiva as vendas, a prestação de serviço, os lucros, a relação com fornecedores e a fiscalização. 


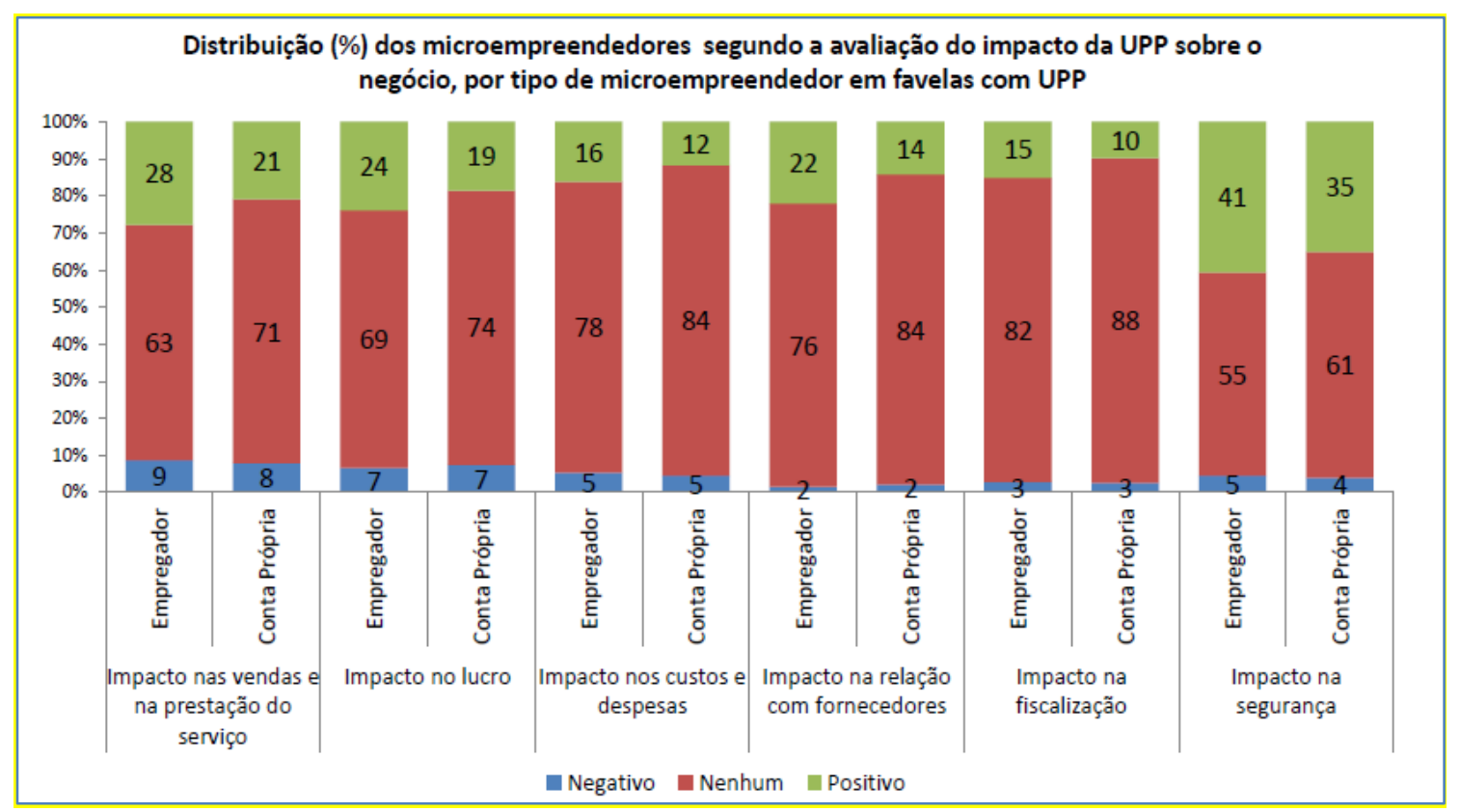

Figura 13 - Percepção do impacto das UPPs sobre os empreendimentos em favelas Fonte: IETS/Sebrae. Pesquisa sobre o microempreendedorismo em domicílios nas favelas com UPP - 2012.

O livro de Meirelles e Athayde (2014) apresenta depoimentos como o de Marivaldo, morador do Complexo do Alemão, que mostram a importância dessa possibilidade de paz: "Quando havia troca de tiros, eu ficava com o coração na mão, sabendo que minha filha ia atravessar a linha da batalha quando voltasse para casa" (MEIRELLES; ATHAYDE, p. 58).

Depoimento muito semelhante ouvimos no Santa Marta:

Antes a comunidade era muito violenta. Eu era auxiliar de enfermagem nos hospitais, tinha dois filhos e ficava preocupada com as crianças quando dormia nos plantões. Quando eu dormia em casa, tinha dias que a gente acordava e encontrava um corpo estendido na porta de casa (Sonia, do grupo Costurando Ideais, favela Santa Marta).

O processo de pacificação das favelas cariocas, iniciado em 2008, desencadeou uma série de mudanças nesses locais. A primeira delas foi a de o morador poder exercer com mais segurança o simples direito de ir e vir. A partir dessa conquista, vieram outras como "[...] a criação e a ampliação dos negócios legais, mesmo aqueles não formais" (MEIRELLES; ATHAYDE p. 58).

Depois da pacificação, nosso trabalho ganhou mais visibilidade. Podemos sair da comunidade e ser convidadas para eventos. Além disso, o ambiente na comunidade melhorou bastante. Agora temos um polo de comercialização lá dentro (Sueli Fernandes de Paula, artesã da Rede Cidade de Deus de Economia Solidária, depoimento, abril 2015). 
A abertura do acesso a esses territórios tem permitido, também, a circulação de frequentadores 'do asfalto', contribuindo para a possível expansão de novos mercados.

\begin{abstract}
Uma coisa que ajudou muito com a pacificação foi quebrar o preconceito que havia com a favela. Hoje se paga caro para passar uma noite na favela, para ir às festas (Depoimento de Sonia Maria de Oliveira, artesã da favela Santa Marta, abril 2015).

Você precisa ver, só filho de bacana nesses eventos. Antes da pacificação não era assim (Depoimento de Marisete Gomes Monteiro, artesã da favela Santa Marta, abril 2015).
\end{abstract}

Além de permitir o trânsito de potenciais consumidores, a abertura do acesso a esses territórios contribuiu para que instituições como o Sebrae intensificassem suas ações de incentivo ao empreendedorismo nas favelas cariocas. Até setembro de 2013, o Sebrae havia atendido cerca de 3 mil pequenos empreendedores, patrocinando mais de mil formalizações nos territórios pacificados do Rio (MEIRELLES; ATHAYDE, 2014, p. 78).

Luiz Barreto, presidente do Sebrae Nacional, sublinha que esses empreendimentos foram fortalecidos com a criação da figura do Microempreendedor Individual (MEI), em 2009, que ofereceu a possibilidade de o empreendedor legalizar seus negócios. Entre os benefícios a que o empreendedor passa a ter acesso depois que se inscreve no MEl estão auxílio-maternidade, auxílio-doença e aposentadoria. Além disso, ele passa a ter maior acesso ao mercado e ao crédito (MEIRELLES; ATHAYDE, 2014, p. 78).

Barreto acredita na força do empreendedorismo como forma de melhorar a qualidade de vida nas favelas e como modelo que está beneficiando toda a sociedade brasileira. Para dar uma ideia da importância desses pequenos negócios, o presidente da entidade, utilizando dados da pesquisa encomendada ao Data Favela, explica que eles são a base do sustento de $20 \%$ dos quase 12 milhões de brasileiros que vivem em comunidades (MEIRELLES; ATHAYDE, 2014, p. 77).

Neste novo cenário, Preto Zé, ex-presidente da CUFA do Brasil e eleito presidente da CUFA Global, em setembro de 2015, destaca "[...] o esforço das mulheres, muitas delas chefes de família, em desenvolver projetos empreendedores" (MEIRELLES; ATHAYDE, 2014, p. 24). De acordo com avaliação do Sebrae, a maior parte dos empreendedores das regiões urbanas de baixa renda é do gênero feminino, tem idade entre 25 e 59 anos, possui ensino fundamental incompleto e renda média de, aproximadamente, $\mathrm{R} \$ 700,00$ por pessoa ao mês (IETS; 2012 a p. 61)

Importante dizer que, apesar do ambiente propício ao desenvolvimento de novos negócios nas favelas, Meirelles e Athayde (2014) ressaltam que os graves problemas estruturais persistem. Na Rocinha, por exemplo, embora o Censo Domiciliar 2008/2009, realizado pela equipe do PAC, aponte para um alto percentual de domicílios ligados à rede 
de esgoto (86,1\%), o esgoto correndo a céu aberto ainda é uma realidade (Plano de Desenvolvimento Sustentável da Rocinha, p. 84). O mau cheiro que exala de um grande valão logo na porta de entrada da favela, a conhecida Rua do Valão, percebido em nossas visitas à Rocinha, é a prova de que o saneamento ainda não foi resolvido. Quando chove, o esgoto e o lixo transbordam.

Moradias úmidas e com pouca luz, amontoando-se em um labirinto de difícil acesso, transformam a Rocinha em um dos locais de maior índice de tuberculose da cidade. Entre 2004 e 2006, a incidência na favela foi de 447,3 casos para cada grupo de 100.000 habitantes, colocando-a entre os bairros de maior incidência da doença na cidade, lado a lado com Bonsucesso (647,7 casos por 100.000 habitantes), Jacaré (460,0 casos por 100.000 habitantes) e Santo Cristo (436,7 casos por 100.000 habitantes) (PEREIRA et al, 2015).

Ainda que a Rocinha tenha iniciado seu processo de pacificação com a ocupação da polícia desde o final de 2011, fomos surpreendidos, em julho de 2015, com a visão, em plena luz do dia, de jovens armados com fuzis no final de uma escadaria em frente às caçambas de lixo. O local de passagem marcava o início da subida do morro. Mais à frente, nos deparamos com a presença de turistas estrangeiros, que pareciam alheios àquela realidade.

Mesmo com todos esses problemas ainda não solucionados, a pesquisa do Data Popular mostra que a maioria dos moradores de favela gosta da comunidade em que vivem (81\%), sendo que $62 \%$ deles têm orgulho de viver no local e $66 \%$ não pensam em se mudar. Afinal, como observa o rapper, ator e escritor MV Bill, nascido e criado em uma das comunidades mais pobres do Rio e hoje transformada em bairro, a Cidade de Deus: "A favela não é somente um lugar para morar, mas para formular, produzir, aprender e viver" (SOARES, 2014, p.17).

Essas pessoas prezam o lugar onde vivem e criam raízes, pois ali nas comunidades encontram o capital social necessário para levar a vida. Sabem que ali podem contar com uma rede de laços sociais, baseada na solidariedade e reciprocidade, para ajudá-las, quando precisam.

Há alguém que pode lhe emprestar algum dinheiro ou o cartão de crédito na hora do aperto. Há outro que pode tomar conta de seus filhos enquanto ele trabalha. E há sempre aquele que pode ouvir suas confissões, no 'divã' improvisado no boteco ou no salão de beleza (MEIRELLES; ATHAYDE, 2014, p. 31).

A partir dessas relações de cooperação, novos empreendimentos vão se fortalecendo nas comunidades. Reduto da criatividade, a favela hoje se reinventa. Iniciativas 
empreendedoras empurradas, na maioria das vezes, pela necessidade de seus protagonistas tornam-se oportunidade de alavancar a vida daqueles que, muitas vezes, estavam à margem. E, assim, ao trazer essas pessoas para dentro do processo produtivo, os empreendimentos pavimentam uma via possível de desenvolvimento local. 


\section{POLÍTICAS PÚBLICAS RELACIONADAS AO ARTESANATO}

\subsection{O ARTESANATO NA CIDADE DO RIO DE JANEIRO}

A produção artesanal, um dos tipos de atividades empreendedoras que cresce nas favelas cariocas, tem despontado como uma alternativa de renda principalmente para as mulheres. A atividade tem sido o foco das ações de políticas públicas da Secretaria Especial de Desenvolvimento Econômico Solidário do município do Rio de Janeiro (SEDES), criada em 2009. Dentre elas, destacam-se as de fomento do desenvolvimento do empreendedorismo nessas comunidades, baseado na lógica da economia solidária. De acordo com Ana Asti, diretora de Economia Solidária e Comércio Justo da SEDES,

a economia solidária é uma economia muito feminina. Pela própria natureza orgânica da solidariedade. A mulher busca a economia solidária, não no sentido de uma política de gênero. Ela se identifica com essa ideia de unir forças em prol de um bem maior. Essa lógica da sobrevivência da família é muito feminina. (Ana Asti, depoimento, novembro de 2015).

A lógica feminina pela sobrevivência, no caso das favelas cariocas, ultrapassa a preocupação exclusiva com a renda das famílias. A possibilidade de trabalhar em casa ou em outro local na própria comunidade permite à mulher manter-se próxima dos filhos, protegendo-os do tráfico de drogas. Ana Asti explica que esse foi um dos motivos que levou, por exemplo, à formação do Grupo Devas, da favela Nova Holanda, uma das 17 comunidades do Complexo da Maré.

O apoio ao empreendedorismo solidário nessas comunidades, oferecido pela SEDES, têm como objetivo principal ampliar as alternativas de trabalho e renda, contribuindo para a superação da exclusão social e potencializando novos mercados.

A economia solidária é uma alternativa para a cidade. Alcançamos essas costureiras e artesãs que vivem nas comunidades, cada uma no seu canto, trabalhando individualmente e incentivamos o associativismo entre elas. Dessa forma essas empreendedoras se fortalecem e conseguem se posicionar (melhor no mercado). (Ana Asti, depoimento novembro de 2015).

As ações políticas voltadas ao fomento do trabalho artesanal em comunidades carentes na cidade do Rio de Janeiro começaram em 2010, quando se iniciou o projeto Rio Economia Solidária (Rio Ecosol). A primeira etapa do projeto foi fruto de uma articulação entre o Ministério do Trabalho e Emprego, por meio da Secretaria Nacional de Economia Solidária e o Ministério da Justiça e a Prefeitura do Rio de Janeiro.

O convênio foi assinado em 2009 e o projeto teve início em outubro de 2010, com a instalação dos primeiros pontos solidários em quatro comunidades da cidade: Alemão, Cidade de Deus, Manguinhos e Santa Marta. De acordo com Ronaldo Teixeira, secretário- 
executivo, na época, do Pronasci (Programa Nacional de Segurança Pública com Cidadania),

a economia solidária representa a segunda parte do processo (de pacificação das comunidades), com possibilidades concretas de consolidação de paz. (TAVARES, 2010).

Esses pontos solidários foram idealizados para serem espaços de construção da lógica da economia solidária naqueles territórios específicos. São locais de encontro e de formação dos empreendedores, onde são ministrados cursos básicos e avançados sobre o tema, e realizadas reuniões das redes locais de economia solidária para organização de eventos e feiras.

Quando o projeto começou, em 2010, entramos no Alemão uma semana antes da invasão (por forças policiais e Exército). Queríamos buscar uma alternativa à economia local que existia antes da pacificação. (Ana Asti, coordenadora de Economia Solidária e Comércio Justo da Secretaria de Desenvolvimento Econômico e Solidário, depoimento, novembro de 2015).

Como é divulgado pelo portal de notícias Rocinha.org, antes da pacificação, o tráfico era responsável não apenas pelo comércio de drogas, mas movimentava muitos dos negócios existentes nas comunidades. A presença da polícia "fuzilou a economia movida a pó" (BERGAMO, M. ${ }^{18}$, Conheça melhor o novo perfil da Rocinha pós-pacificação).

A alternativa apresentada pela Secretaria Municipal de Desenvolvimento Econômico e Solidário para superar essa economia estimulada pela venda de drogas foi o fortalecimento do empreendedorismo solidário.

Em termos de investimento, a primeira etapa do Rio Ecosol recebeu 8 milhões de reais do Ministério da Justiça, por meio do Pronasci. Já o Rio Ecosol II, rebatizado de Rio Economia Solidária para Superação da Pobreza, chegou aos territórios em 2014 e recebeu do Ministério do Desenvolvimento Social 4 milhões de reais. Os recursos vieram via SENAES. A Prefeitura do Rio de Janeiro executou os investimentos.

As comunidades alcançadas pelo Rio Ecosol II foram o Complexo da Maré, o Morro da Coroa e as comunidades Antares e Palmares, na Zona Oeste da cidade. Tanto essa fase do programa como a primeira terminaram no final de 2015. Como resultado, além da criação de diversos pontos de economia solidária nessas comunidades e da realização de cursos de capacitação, foi incentivada a criação de redes. No Complexo da Maré, por exemplo,

\footnotetext{
${ }^{18}$ Disponível em: <http://www.rocinha.org/noticias/rocinha/view.asp?id=2800>. Acesso em: 20 dez. 2015.

${ }^{22}$ Ministério da Justiça libera $\mathrm{R} \$ 8$ milhões para a economia solidária em favelas do Rio. Disponível em: <http://www.df.agenciasebrae.com.br/sites/asn/uf/DF/Minist\%C3\%A9rio-da-Justi\%C3\%A7alibera-R\$-8-milh\%C3\%B5es-para-a-economia-solid\%C3\%A1ria-em-favelas-do-Rio, 2/12/2010>. Acesso em: 30 jan. 2016.
} 
formou-se a rede Resolmar. A possibilidade de autogestão, explica Ana Asti, é o maior legado do projeto.

Temos resultados no plural. Já é possível ver a rede de economia solidária funcionando nessas comunidades, os empreendedores se encontrando, organizando ações em conjunto e já vivendo do próprio negócio, mas ainda não conseguimos dizer que mudamos a vida das comunidades. Estamos diante de um grande desafio. (Ana Asti, depoimento, novembro de 2015).

As principais ações da Secretaria têm se desenvolvido em torno de alguns eixos. O primeiro é focado na qualificação do empreendedor, dando-lhe oportunidade de melhorar o seu produto e desenvolver uma gestão mais focada no coletivo. De acordo com essa lógica, é estimulada a formação de redes locais que irão dialogar com o movimento social da economia solidária e que fazem parte, hoje, do Fórum Municipal de Economia Solidária.

O segundo eixo é a comercialização, no qual se inclui a temática do comércio justo, começando pelas feiras. A partir desse eixo, surge o Circuito Carioca de Economia Solidária, instituído pelo Decreto no 34,388 , de 8 de setembro de 2011 . Fruto de uma parceria da SEDES com o Fórum Municipal de Economia Solidária do Rio de Janeiro, o Circuito promove feiras nas comunidades e em determinados pontos da cidade para o escoamento da produção artesanal da economia solidária. Essas feiras são organizadas dentro da lógica do trabalho coletivo, que valoriza a capacidade de autogestão dos grupos e o fortalecimento deles ao se conectarem em redes.

Quando as feiras acontecem dentro da comunidade, as operações de compra e venda de produtos locais fazem com que o dinheiro circule ali mesmo, incentivando diretamente o desenvolvimento local. Mas nem sempre as comunidades têm a cultura de comprar localmente, como acontece no Complexo do Alemão. Os moradores da favela Santa Marta, por exemplo, consomem mais em outros lugares do bairro de Botafogo (ASTI, 2012).

No entanto, como veremos no capítulo 6, depois que a Santa Marta foi pacificada aumentou o fluxo de pessoas de fora da favela interessadas em conhecer o local. A partir daí, cresceu a oferta de hospedagem, tours pelo morro, produção de alimentos e artesanato para atender a demanda desses novos consumidores.

As praças do Largo do Machado, no Flamengo e da General Osório, em Ipanema, são alguns dos locais onde acontecem as feiras quinzenais na cidade (Figuras 14 e 15). Lugares de grande circulação de pessoas, devido à presença das estações do metrô, esses eventos funcionam como enormes vitrines do Projeto Rio Ecosol. "No ano passado, as feiras nesses pontos estratégicos venderam mais de 500 mil reais. Este ano, em que estamos abrindo novos pontos, as vendas ultrapassaram a marca de 2 milhões com 10 
feiras mensais" (ASTI, depoimento, novembro de 2015, com valores atualizados em abril de 2016).

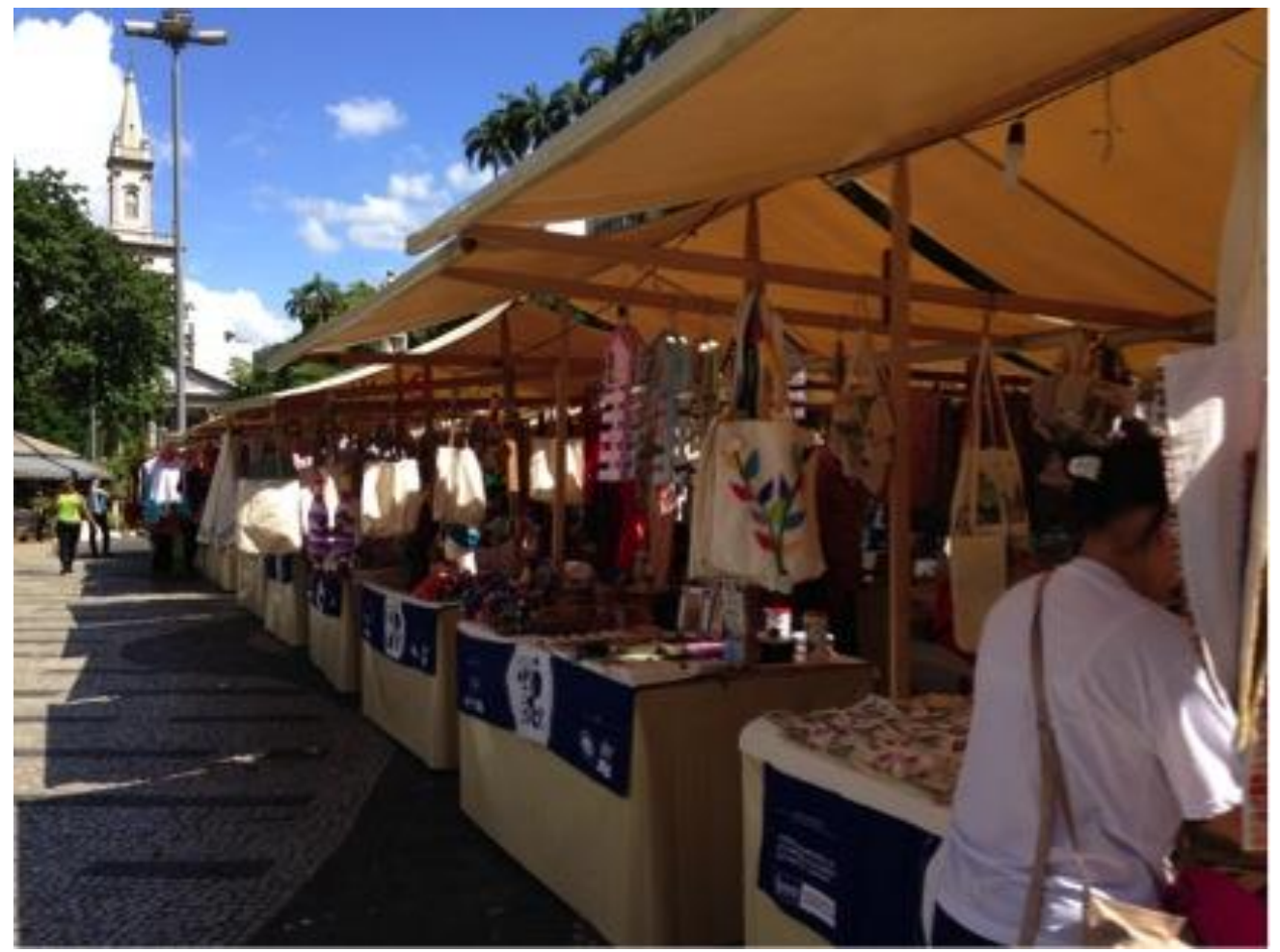

Figura 14 - Feira Rio Ecosol de artesanato - Praça do Largo do Machado

Fonte: Foto tomada pela autora 


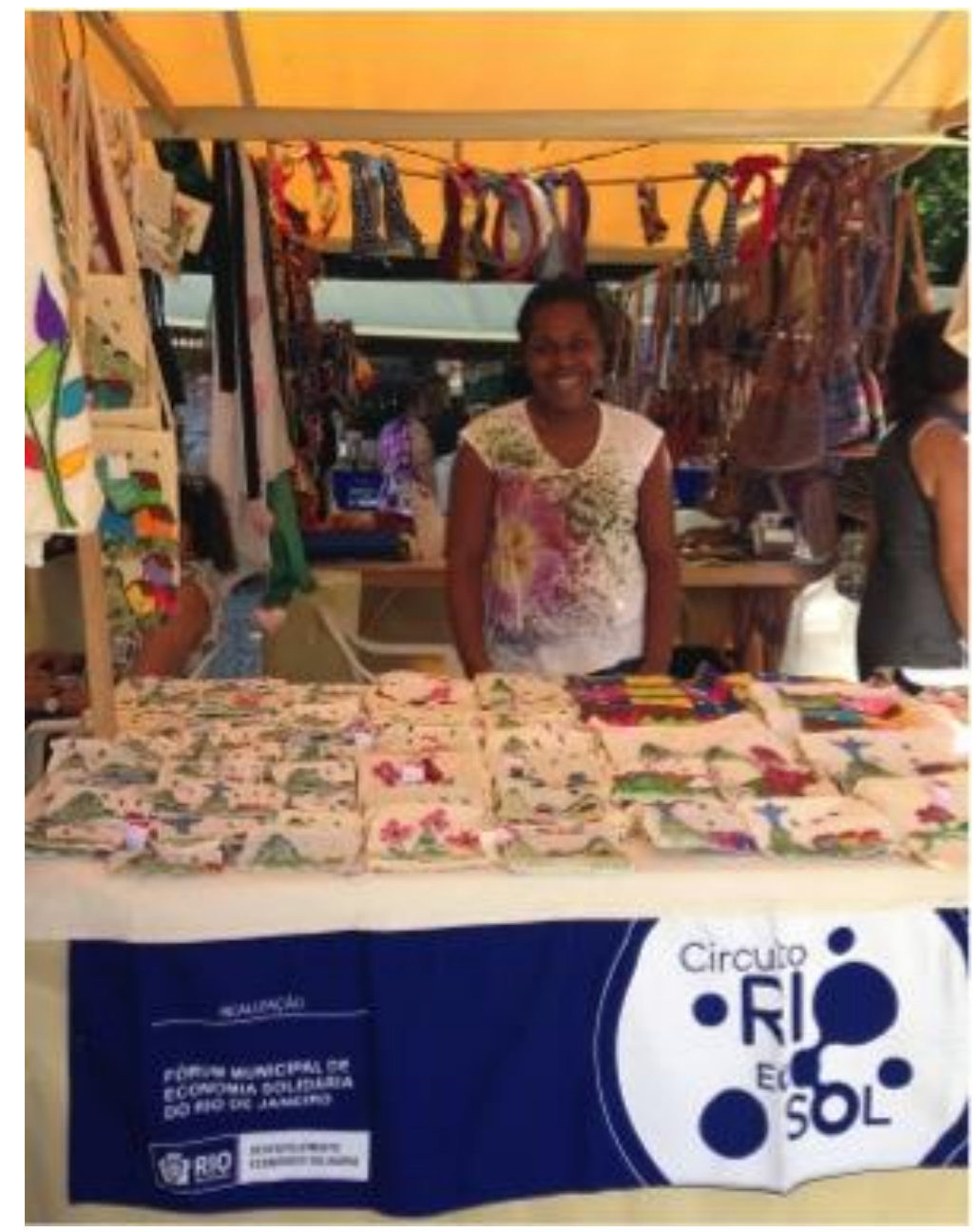

\section{Figura 15 - Feira Rio Ecosol de artesanato - Praça do Largo do Machado}

Fonte: Foto tomada pela autora

Apesar dos bons resultados das vendas, Ana Asti explica que ainda tem muito artesão vendendo pouco nesses eventos. Mas, em sua opinião, isso não invalida a participação desses produtores. As feiras, ela ressalta, são oportunidades para os artesãos apresentarem o seu produto, testarem sua capacidade de inserção no mercado e ampliarem a comunicação com o consumidor.

Para aumentar o valor agregado dos produtos, foi firmada uma parceria da SEDES com o Sebrae durante o Projeto Rio Ecosol I. Por meio parceria, foram financiados, em 2011, alguns designers para trabalharem na melhoria da produção artesanal nas quatro comunidades atendidas nessa fase do projeto: Manguinhos, Santa Marta, Alemão e Cidade de Deus. 
No Rio Ecosol II, a assistência técnica aos produtores foi ampliada. Então, foram convidados designers para desenvolvimento de novos produtos, melhoria de qualidade daqueles que já existiam e produção de embalagem.

O terceiro eixo da política de economia solidária no Rio de Janeiro é o das finanças solidárias. Segundo Asti (depoimento, novembro de 2015), este eixo ainda está pouco desenvolvido, mas constitui-se uma meta para os próximos anos.

Chegamos a apoiar a criação de um banco solidário na Cidade de Deus, mas foi um projeto piloto. Não teve escala financeira. Precisava da injeção de mais recursos para a moeda realmente ser apropriada pelos estabelecimentos na comunidade. Atualmente o banco é gerido pela Agência de Desenvolvimento Local da comunidade. (ASTI, depoimento, novembro de 2015).

Agora a SEDES está investindo em uma nova tecnologia que é a moeda social eletrônica. A novidade irá permitir, por meio de um software, que as transações comerciais, de compra e venda, sejam feitas pelo celular.

Esse projeto da moeda social eletrônica permitirá que a comercialização saia da nota material e ganhe escala virtual, permitindo que se multiplique rapidamente na comunidade. O banco comunitário continuará existindo e a ideia é que, depois de um ano de projeto, a comunidade assuma o banco. (ASTI, depoimento, novembro de 2015).

O quarto eixo é o da institucionalização da política pública da economia solidária no município do Rio de Janeiro (Lei $\mathrm{n}^{\circ}$ 5.435, de 12 de junho de 2012). Nesse sentido, foi criado o Conselho Municipal de Economia Solidária, pela Lei $\mathrm{n}^{\circ}$ 5.432, de 12 de junho de 2012, regulamentada um ano depois pelo Decreto $n^{\circ}$ 38.218, de 18 de dezembro de 2013. Em janeiro de 2015, seus membros foram empossados. Sua composição é paritária entre o privado e o público: quinze representantes de secretarias do município e 15 representantes da sociedade civil organizada (empreendedores de economia solidária e entidades de apoio e fomento).

Uma das realizações desse Conselho foi a criação do Plano Municipal de Economia Solidária, com os objetivos e estratégias da política para o próximo período de quatro anos (2016-2020). Mais uma demonstração de que ela vem se consolidando cada vez mais na cidade.

\subsection{O ARTESANATO E A ECONOMIA SOLIDÁRIA: PRODUZIR COM AS MÃOS A VIDA}

Entendido como um tipo de produção pré-capitalista, historicamente superada pela produção manufaturada com o desenvolvimento da indústria e a própria dinâmica do capital, 
o artesanato, hoje, é uma das atividades apoiadas pela Secretaria Nacional de Economia Solidária (SENAES).

Consideramos que a produção artesanal é uma forma de resistência das pessoas a manter sua autonomia no processo de produção do trabalho sem subordinação direta ao capital. (Depoimento de Valmor Schiochet, diretor de Estudos e Divulgação da SENAES, outubro de 2015).

A economia solidária é uma organização econômica fundamentada nas formas associativas de produção, como associações e cooperativas; na autogestão do trabalho; na participação democrática e na valorização do capital humano. Schiochet (2015) explica que, no Brasil, a economia solidária tem, basicamente, dois tipos de organização econômica associativa. O primeiro é constituído pelas organizações coletivas em que os produtos e os serviços são resultados da atuação conjunta de um grupo de pessoas. Essas seriam, tipicamente, as cooperativas ou as associações de trabalhadores, em que a cooperação acontece no processo de trabalho em si.

O segundo tipo de organização associativa é constituído por formas associativas e cooperativas de produtores, nas quais as pessoas produzem bens materiais e imateriais individualmente, de forma autônoma e se associam para viabilizar essa produção ou a comercialização dessa produção. Nesse caso, podem se associar para compartilhar um espaço comum, para fazer aquisição de insumos, compartilhar equipamentos ou para a comercialização.

$\mathrm{Na}$ concepção da SENAES, o trabalho artesanal realizado nas comunidades se encaixaria nessa segunda forma de organização. "Os artesãos fazem a atividade artesanal, individualmente ou em família, organizando-se em uma associação, geralmente para viabilizar a comercialização" (Schiochet, depoimento, outubro de 2015).

No entanto, a organização de um grupo em torno da produção ou comercialização, somente, não o enquadra necessariamente dentro da lógica da economia solidária. Em nossas visitas de campo a grupos de artesãs, vimos que o Coopa-Roca, da Rocinha, por exemplo, embora tivesse características para tornar-se um projeto de economia solidária, sua trajetória não foi conduzida dentro do paradigma que esse tipo de economia requer. Organizadas para funcionar como cooperativa, as artesãs dividem o mesmo local de trabalho, as mesmas máquinas. No entanto, elas se queixaram de nunca ter havido participação democrática na gestão. As artesãs eram alijadas dos processos decisórios, que ficavam concentrados nas mãos de uma única pessoa. Somente no início de 2015, com a mudança de coordenação é que elas passaram a tomar à frente dos negócios. Até aquela data o grupo ainda não havia se tornado formalmente um projeto de economia solidária 
A partir do conceito de economia solidária, Schiochet diferencia o empreendedorismo solidário do empreendedorismo tradicional. O primeiro propõe-se a ser uma alternativa associativa ou coletiva. Mesmo inserido em uma lógica competitiva e concorrencial de mercado, o empreendimento é organizado em torno da ação coletiva, da partilha e de estratégias comuns. Ele pode ser, por exemplo, uma unidade de cooperação produtiva, de comercialização ou de finanças.

Já o empreendedorismo tradicional envolve uma estratégia mais individualista de autonomia concorrencial e competitiva. "É uma forma autônoma de a pessoa constituir o seu negócio, tornar-se competitivo com ele e conseguir dar conta da concorrência" (Schiochet, depoimento, outubro de 2015).

No nosso trabalho de campo, observamos que, na maioria dos casos, as artesãs dividem o local de trabalho, os meios de produção (as máquinas de costura, por exemplo), e, muitas vezes, a compra dos insumos e o lucro de sua atividade.

De acordo com informações da SENAES, em 9 de outubro de 2015, no Estado do Rio de Janeiro, havia 346 empreendimentos de economia solidária inscritos no CADSOL. Desses, 45 ainda estavam em processo de análise. Nos 301 já avaliados, havia 8.039 sócios(as). Os empreendimentos de artesanato somavam 163, ou seja, mais da metade entre os mapeados. Neles havia 2.302 sócios, sendo que 1.945 eram mulheres.

A informação foi fornecida com a ressalva de estar com números bastante subestimados, devido a problemas técnicos no último levantamento. No mapeamento de 2005/2007, foram listados no município 1.343 empreendimentos e 64.846 sócios(as). Desses, 557 eram de artesanato, sendo 90 somente na cidade do Rio.

No município do Rio de Janeiro, foram mapeados entre 2009 e 2012 o total de 121 empreendimentos, sendo 59 compostos por artesãos. Os 121 empreendimentos somam 2.394 sócios, sendo 1.330 mulheres. Já os 59 empreendimentos de artesanato somam 898 pessoas, sendo 669 sócias.

Em relação às categorias sociais dos empreendedores da economia solidária mapeados pela SENAES, entre 2010 e 2013, a de artesanato é a segunda maior (17\%) (Figura 16). Mas Schiochet explica que, entre os coletivos de agricultores familiares, assentados de reforma agrária e catadores de material reciclável, existem, também, artesãos. Eles, porém, não entram nessa contabilidade, pois não se autodeclaram artesãos ao definirem sua atividade principal.

Essa fatia de $17 \%$ de empreendedores do artesanato reúne 104 mil pessoas. Em relação aos empreendimentos do artesanato, 60\% estão na informalidade e 34\% são organizados sob a forma de associações. Já em relação aos empreendimentos em geral, a 
maior parte é constituída por associações (60\%) e 30\% desses empreendimentos estão na informalidade (Schiochet, depoimento, outubro de 2015).

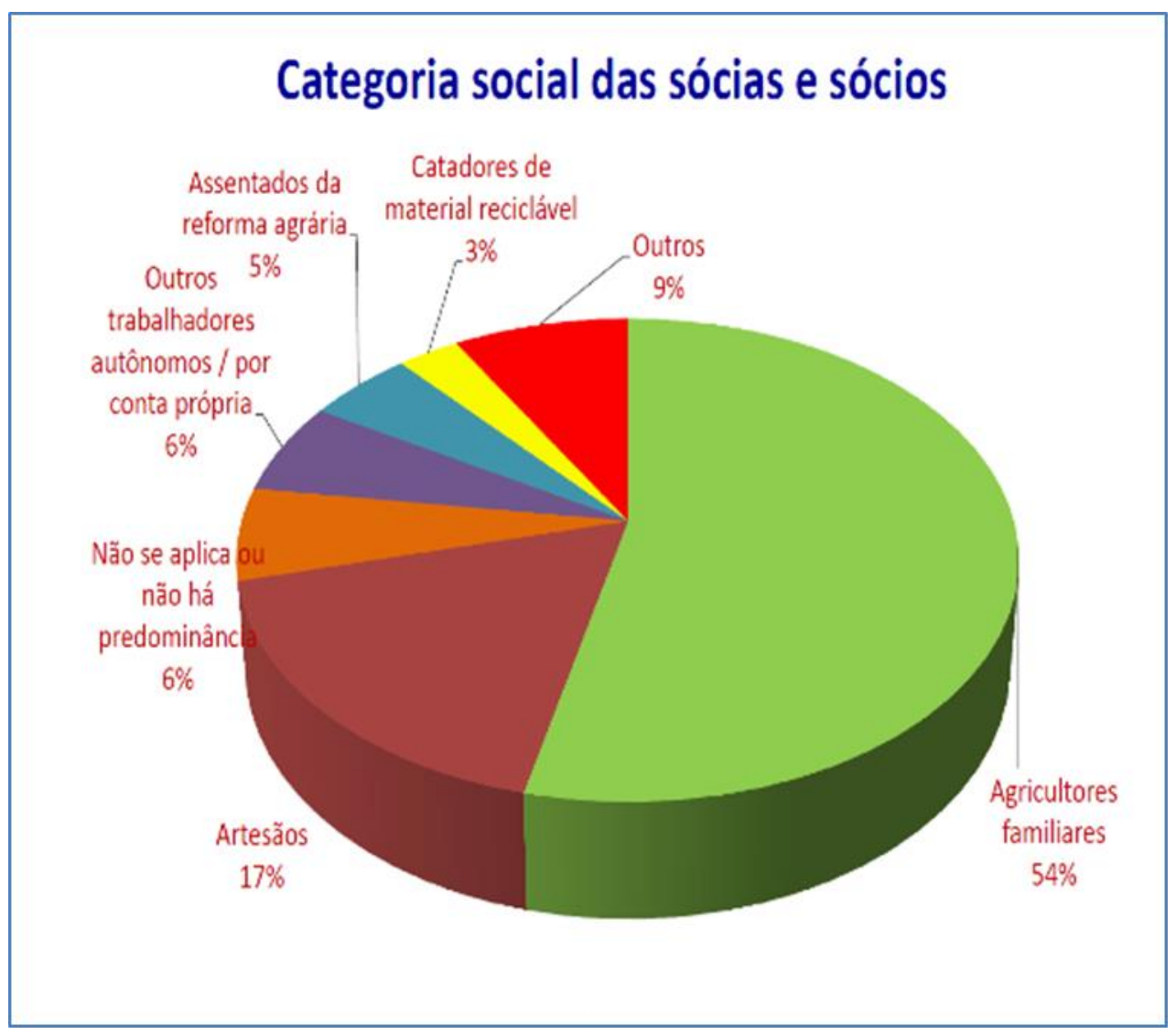

Figura 16 - Categoria social das sócias e sócios da economia solidária no Brasil em 2013.

Fonte: SENAES / MTE

Importante ressaltar que muitos desses empreendimentos, mapeados pela SENAES como de artesanato, seriam considerados trabalho manual pelo Programa do Artesanato Brasileiro, gerido pela Secretaria de Micro e Pequena Empresa.

\footnotetext{
O artesanato para este programa tem uma concepção mais restrita e elitista em termos de design, de arte, de associação do produto com a cultura local, diferente do que faz essa turma aqui que é produzir com as mãos a sua vida. (Schiochet, depoimento, outubro de 2015).
}

Em relação às principais ações políticas voltadas ao fomento do artesanato, Schiochet esclarece que não existe uma ação específica da Secretaria Nacional de Economia Solidária para o artesanato, pois o Programa Brasileiro do Artesanato está em outro ministério no governo federal. Mas, como a base social da economia solidária tem uma participação importante do artesanato, as ações políticas da SENAES acabam beneficiando muito a produção artesanal. "Esse apoio acontece basicamente na comercialização, porque as feiras de economia solidária são constituídas principalmente por artesanato ou trabalhos 
manuais, se consideramos a diferença entre eles adotada pelo Programa do Artesanato Brasileiro" (Schiochet, depoimento, outubro de 2015).

Além disso, por meio de política específica de apoio às organizações associativas e às cooperativas de catadores de material reciclável, a SENAES acaba indiretamente beneficiando, também, os artesãos. Parte das atividades realizadas pelos catadores é a reciclagem de material e, a partir daí, a produção de produtos artesanais.

No final de 2015, a SENAES avaliava uma demanda das organizações representativas dos artesãos para que a política de artesanato passasse a ser tratada como política de trabalho. Tal demanda surge a partir da constatação de que, nas feiras de economia solidária, hoje, existe muito artesanato, mas esse artesanato não é reconhecido como tal pelo Programa do Artesanato Brasileiro (PAB).

Assim como o conceito de artesanato se diferencia entre as pastas do governo federal, não há coordenação nessa esfera de governo para fazer a articulação de uma política voltada a essa atividade, embora exista o Programa do Artesanato Brasileiro (PAB).

No caso do artesanato eu não conheço uma articulação interministerial para coordenar o conjunto das políticas que apoiam o artesanato. Sabemos que existe um conjunto de ações que acabam apoiando o artesanato, aqui na SENAES; no Ministério do Desenvolvimento Agrário, no caso do artesanato da agricultura familiar e dos assentamentos de reforma agrária; no Ministério da Cultura e na Secretaria de Micro e Pequena Empresa, mas não existe um organismo que conduza a articulação dessas políticas no governo federal. (Schiochet, depoimento, outubro de 2015).

A SENAES, apesar de não ter uma trajetória de ação direta voltada ao artesanato, percebe, hoje, a potencialidade de maior aproximação com o setor. A partir dessa percepção, pode-se dizer que há um reconhecimento da importância da produção artesanal como base da economia solidária e dos desafios de um olhar mais específico para esse tipo de trabalho.

\subsection{O ARTESANATO E O MINC: O REPOSICIONAMENTO SIMBÓLICO NA BUSCA DE UM CIRCUITO MAIS CULT}

O Ministério da Cultura tem enfatizado o significado do artesanato como produto da cultura popular e direciona, atualmente, o foco de sua política para a ampliação de sua visibilidade em circuitos considerados mais cults.

Temos trabalhado o conceito (de artesanato) de maneira mais ampla, pois são modos de vida que produzem uma estética, uma linguagem que vem da cultura popular, de uma experiência cotidiana, de uma remixagem de repertórios (Ivana Bentes, Secretária da Cidadania e da Diversidade Cultural (SCDC/MinC), depoimento, outubro de 2015). 
No segundo semestre de 2015, a partir da recondução de Juca Ferreira ao cargo de ministro, ocorrida em janeiro daquele ano, a coordenação da política do artesanato no MinC sai da Secretaria de Economia Criativa e vai para a Secretaria de Cidadania e Diversidade Cultural. A Secretaria de Economia Criativa, criada na gestão Ana de Hollanda, é extinta.

A Secretaria de Cidadania e Diversidade Cultural coordena, dentro do MinC, o Colegiado Setorial do Artesanato, que faz parte do Conselho Nacional de Política Cultural. O Colegiado Setorial de Artesanato é composto por membros da sociedade civil e do poder público e tem como função integrar a participação popular para a construção de políticas públicas relacionadas à área.

No final de 2014, foi iniciado o processo de construção do Plano Setorial do Artesanato de autoria do Colegiado Setorial do Artesanato. Nessa época, foram colocados em consulta pública os eixos que nortearão as políticas públicas para o artesanato pelos próximos 10 anos: criação e produção; formação e capacitação; divulgação; distribuição e comercialização; fortalecimento do artesanato; economia, sustentabilidade ambiental e inovação (BRASIL, Ministério da Cultura, 2014), .

De lá para cá, o Plano Setorial do Artesanato foi sistematizado e precisa ser retomado pela nova gestão do Conselho Nacional de Política Cultural, empossada em dezembro de 2015. (Rejane Nóbrega, coordenadora do Colegiado do Artesanato no MinC, depoimento, outubro de 2015).

O artesanato no MinC, no entanto, não se restringe apenas a essa Secretaria. Ele é um dos bens culturais preservados pelo Instituto do Patrimônio Histórico e Artístico Nacional (IPHAN). E, historicamente, sempre esteve ligado às atribuições do Centro Nacional de Folclore e Cultura Popular (CNFCP), que integra a estrutura do IPHAN. Um dos programas de destaque do Centro voltado ao apoio à produção artesanal é o Promoart, Programa de Promoção do Artesanato de Tradição Cultural.

O Promoart busca a valorização cultural do artesanato que tenha enraizamento na cultura local e expresse a identidade cultural de determinados grupos sociais, com investimentos desde a organização da cadeia produtiva, até a divulgação e a comercialização dos produtos. Com isso, o programa busca alcançar a sustentabilidade econômica e social desse tipo de produção, assegurando e expandindo a participação dela em mercados qualificados.

Embora o foco do IPHAN, do CNFCP e do Promoart seja o artesanato de tradição cultural, o MinC considera o artesanato em todas as suas dimensões: desde o artesanato indígena e outros tipos de artesanato de base tradicional, até o artesanato urbano. Essa amplitude está expressa, também, na própria composição do Colegiado Setorial do 
Artesanato, onde há "desde artesãos de base tradicional até aqueles que fazem artesanato como uma atividade manual" (Nóbrega, depoimento, outubro de 2015).

O artesanato indígena, as roupas produzidas para terreiros de candomblé e técnicas como o crochê produzido nas favelas e na periferia são destacadas pela Secretária da Cidadania e da Diversidade Cultural do MinC, Ivana Bentes, como exemplo de um "saber fazer" cultural brasileiro extremamente sofisticado.

Essas roupas do candomblé são alta-costura, Versace, podiam estar na
maior passarela de moda do mundo. Nosso artesanato indígena é
lindíssimo. No último Encontro de Culturas Tradicionais realizado na
Chapada dos Veadeiros, vi um americano tentando intermediar artesanato
dos índios para lojas em Nova lorque. Mas, hoje, ainda vivemos um total
apartamento desses circuitos de luxo. (Bentes, depoimento, outubro de
2015).

No caso da produção artesanal das favelas e periferias, a situação é mais grave, "pois nem como cultura popular é considerada. É uma produção ainda mais sem lugar, mais desvalorizada, porque é urbana e não veio do campo cultural tradicional" (Ivana Bentes, depoimento, outubro de 2015).

A política de valorização da produção artesanal brasileira envolve, muitas vezes, a necessidade de aprimoramento do produto final, com a utilização, por exemplo, de matériaprima de melhor qualidade. Outras vezes, é preciso ser incentivada a busca de uma expressão artística que reflita a identidade local. Isso pode ser buscado mesmo no caso das favelas.

Esse é um trabalho a ser feito, pois o artesanato sofre, também, os efeitos da globalização, da influência externa. Para isso é preciso que seja dada mais importância a esse setor, a essa cadeia produtiva. Dentro do Ministério da Cultura estamos indo no caminho certo, mas ainda temos muito a percorrer (Nóbrega, depoimento, outubro de 2015).

Em nossas idas a campo, vimos essa preocupação pela busca de uma identidade local em dois grupos. O grupo Mulheres Guerreiras, do Morro da Babilônia e o Grupo Costurando Ideais, da favela Santa Marta.

Nossos produtos têm como motivos, como identidade visual, a própria comunidade, o Pão de Açúcar e o Cristo. O Orfeu Negro foi filmado aqui na Babilônia, em 1959, por uma cineasta francesa. Esse filme foi inspirador também para os nossos produtos (Vera Rufino, abril de 2015. Em nossa segunda visita, em julho, Vera já havia saído do grupo).

A intervenção de uma designer, de uma expert para o aprimoramento do produto artesanal não é uma questão trivial. Muitas vezes contribui para uma melhor colocação do produto no mercado, por meio da utilização de outra matéria-prima, como, por exemplo, a substituição da linha sintética brilhosa pela linha de algodão na confecção de almofadas, tornando o produto mais agradável ao toque. Em outros casos, essa intervenção pode 
interferir na autonomia do artesão, transformando-o em mero executor de projeto imposto de cima para baixo.

Por tentar, muitas vezes, homogeneizar as singularidades dos grupos artesanais e empacotar o produto em uma mesma embalagem, o Sebrae vem recebendo críticas dentro do Ministério da Cultura. "Essa é uma das questões que queremos aprofundar a discussão aqui no Ministério da Cultura, de como fazer essa intervenção, sem interferir na capacidade criativa do artesão" (Nóbrega, depoimento, outubro de 2015).

A valorização do produto artesanal envolve, além da busca de uma melhoria na arte de finalização do produto, uma ampliação de sua visibilidade. "Nossa ideia é colocar o produto cultural dentro da lógica da rede da economia solidária, que serve para a periferia e para o agricultor familiar" (Ivana Bentes, depoimento, outubro de 2015).

Uma das ações previstas dessa parceria com a Secretaria da Economia Solidária do Ministério do Trabalho e Emprego é a organização, em conjunto, da próxima Teia, que é o encontro dos Pontos de Cultura em abril de 2016. No evento, cujo tema será Economia Viva, os diversos Pontos de Cultura terão a oportunidade de mostrar e comercializar seus produtos culturais, entre eles o artesanato.

Assim como as Feiras da Eco-Sol que já acontecem no Rio de Janeiro, esse evento, organizado na lógica das feiras de economia solidária, será uma oportunidade de reposicionar esses produtos artesanais, inclusive os de artesanato urbano, da favela. (Ivana Bentes, depoimento, outubro de 2015).

Embora, como vimos no item anterior, a lógica da economia solidária se fundamente numa base mais ampla, envolvendo todo o processo de produção e não apenas a organização da comercialização, o artesanato deve se beneficiar com mais essa oportunidade para aumentar sua visibilidade.

\subsection{O ARTESANATO E A SECRETARIA DE MICRO E PEQUENA EMPRESA: O QUE VALE É O PRODUTO COM IDENTIDADE CULTURAL}

Dentro do governo federal, a Secretaria de Micro e Pequena Empresa da Presidência da República é a instância responsável pelo Programa do Artesanato Brasileiro (PAB). Na página oficial do programa na internet, ele é apresentado pela sua finalidade:

Coordenar e desenvolver atividades que visam valorizar o artesão brasileiro, elevando o seu nível cultural, profissional, social e econômico, bem como desenvolver e promover $o$ artesanato e a empresa artesanal, no entendimento de que artesanato é empreendedorismo. (Acesso: 10 out. 2015). 
Importante ressaltar que, na sua política em prol da promoção do artesanato brasileiro, essa Secretaria considera fundamental a distinção entre o artesanato e o trabalho manual. O artesanato seria todo produto originário de matéria-prima bruta ou manufaturada que tenha sofrido transformação e que possua identidade cultural. Isso significa dizer que esse produto é a expressão de uma cultura local.

Já o trabalho manual seria todo produto feito à mão, que não passa por transformação da matéria, não tem identidade cultural nem criatividade e, geralmente, é cópia de outra peça. Exemplos de trabalhos manuais seriam aqueles modelos aprendidos a partir de revistas do tipo Faça Fácil ou a partir de programas de televisão, como o da Ana Maria Braga. O produto pode ser até um bordado, mas um bordado sem criatividade.

De acordo com essa lógica, avaliamos que produtos feitos a partir da costura à máquina, tais como roupas, não se classificariam nem como trabalho manual nem como artesanato.

Entendemos que tanto o trabalho artesanal como o trabalho manual tem que ser feito pelo menos $90 \%$ à mão. Se um produto é feito $90 \%$ à máquina, ele não é mais um produto manual, ele é um trabalho feito com equipamentos, sai do tradicional (Ana Beatriz Ellery, Coordenadora do Programa do Artesanato Brasileiro, depoimento, outubro de 2015).

Esse é um exemplo que demonstra a diferença de entendimento sobre o que sejam artesanato e trabalho manual no governo federal. Embora não sejam considerados artesanato nem trabalho manual pela Secretaria de Micro e Pequena Empresa, produtos feitos a partir da costura à máquina fazem parte das Feiras Rio Ecosol, cujo principal objetivo é a comercialização tanto de trabalhos manuais como de produtos artesanais feitos por artesãs e artesãos da economia solidária.

Nas quatro feiras nacionais apoiadas pelo Programa do Artesanato Brasileiro, a participação de cada um deles tem uma proporção determinada. O artesanato é responsável por $80 \%$ dos produtos expostos de cada estado, os outros $20 \%$ são trabalhos manuais.

\begin{abstract}
Em nossas feiras a gente quer que as pessoas sintam-se em contato com a cultura do estado de onde as peças artesanais são provenientes, por isso elas precisam ter uma identidade cultural. Já as feiras da economia solidária não têm essa preocupação, o objetivo delas é a inclusão social. (Ana Beatriz Elllery, depoimento, outubro de 2015).
\end{abstract}

Nas feiras regionais do Programa de Artesanato Brasileiro, não existe essa proporção rígida que limita a participação máxima dos trabalhos manuais. A preocupação maior é garantir a presença desses produtos. Cada município deve levar, no mínimo, 20\% de trabalho manual. Se quiser, pode levar até $100 \%$ de trabalho manual. A exigência que cada município leve, pelo menos, $20 \%$ de trabalho manual para essas feiras serve para assegurar a inclusão de quem não está sendo contemplado nas feiras nacionais. 
Embora a inclusão social não seja o foco principal das ações da Secretaria de Micro e Pequena Empresa, relacionadas à produção artesanal, Ellery admite que existe, nas coordenações estaduais do PAB, uma preocupação em apoiar produtores que estejam passando por situações de vulnerabilidade social.

As coordenações estaduais procuraram identificar e incentivar o
associativismo de, por exemplo, grupos de mulheres que estejam
atravessando essas situações e que possam encontrar no trabalho manual
uma forma de sobrevivência. (Ellery, depoimento, outubro de 2015).

As feiras regionais servem como uma oportunidade do produtor ter o seu trabalho avaliado e perceber que precisa melhorar sua qualidade para conseguir participar das feiras nacionais como artesão.

São grandes cenários para a gente captar ali pessoas que possam vir um dia a atender às feiras nacionais. Fazemos um trabalho de incentivo a esse produtor que já tem a técnica do saber fazer, para ele começar a usar sua criatividade, sair do trabalho manual e um dia vir a ser reconhecido como artesão (Ellery, depoimento, outubro de 2015).

A agregação de valor aos produtos para uma maior inserção no mercado é uma das preocupações desse programa. Para isso, nas feiras regionais, as coordenações estaduais do PAB, em parceria com o Sebrae, oferecem apoio aos produtores organizados em entidades representativas. São oferecidos cursos de capacitação, nos quais a importância das peças terem identidade cultural é sublinhada.

Quando acontecem as feiras nacionais, a produção artesanal recebe cuidado especial até mesmo na forma como é exposta. "Cuidamos para que as peças artesanais sejam apreciadas como peças de arte" (Ellery, depoimento, outubro de 2015).

A interferência do designer sobre o trabalho do produtor na busca de valorização dos produtos é vista com cuidado pela secretária de Micro e Pequena Empresa. Embora reconheça que, muitas vezes, o designer consiga dar um toque diferenciado às peças, na opinião dela, o designer não deve impor uma forma de fazer e muito menos propor, ao artesão, simplesmente a reprodução de um modelo de peça criada por ele. O resultado, nesse caso, seria a homogeneização da produção, ou seja, uma produção em série toda igual. "Estamos falando de arte. Ela deve ser a expressão de quem faz. Quem tem que saber o que é bonito ou não é o artesão" (Ellery, depoimento, outubro de 2015).

Outra estratégia da Secretaria de Micro e Pequena Empresa para valorizar o artesanato brasileiro e ampliar o seu potencial de comercialização é a criação de um selo para exportação.

Estamos trabalhando nisso para o Plano Plurianual (PPA) de 2016 a 2019, pois acreditamos que o selo vai facilitar a entrada dos nossos produtos no mercado externo. Sabemos hoje que já existem artesãos brasileiros que 
conseguem vender mais para fora do país do que no mercado interno, mas identificamos que a entrada nesse mercado não é fácil. As exigências a serem atendidas são grandes. Exigências que o Brasil ainda não têm, principalmente quando o assunto é qualidade (Ellery, depoimento, outubro de 2015).

Além de garantir a qualidade do produto, a certificação do artesanato brasileiro irá assegurar que a produção está de acordo com as normas ambientais dos países compradores.

Outra frente de trabalho na qual a Secretaria de Micro e Pequena Empresa tem se debruçado, nos últimos anos, é a questão da regulamentação da profissão do artesão. No final de outubro de 2015, foi sancionada pela Presidência da República a lei do artesão (Lei n 13.180), que regulamenta a profissão. Embora reconheça a importância da lei, Ellery diz que a regulamentação precisa ser aprimorada, pois a lei foi sancionada de forma muito vaga.

Identificamos pontos falhos na lei que está sendo aprovada. Por exemplo, ela se refere ao artesão como qualquer pessoa que trabalhe com as mãos. Esse é um conceito muito amplo, que pode abarcar profissionais nem artesãos nem trabalhadores manuais. Pedimos a reformulação desse artigo, mas não conseguimos. A lei passou com o artigo original (Ellery, depoimento, outubro de 2015).

\section{LEI № 13.180, DE 22 DE OUTUBRO DE 2015}

Dispõe sobre a profissão de artesão e dá outras providências.

Art. 1ํㅡㄹ Artesão é toda pessoa física que desempenha suas atividades profissionais de forma individual, associada ou cooperativada.

Parágrafo único. A profissão de artesão presume o exercício de atividade predominantemente manual, que pode contar com o auxílio de ferramentas e outros equipamentos, desde que visem a assegurar qualidade, segurança e, quando couber, observância às normas oficiais aplicáveis ao produto.

Art. $2^{\circ} \mathrm{O}$ artesanato será objeto de política específica no âmbito da União, que terá como diretrizes básicas:

I - a valorização da identidade e cultura nacionais;

II - a destinação de linha de crédito especial para o financiamento da comercialização da produção artesanal e para a aquisição de matéria-prima e de equipamentos imprescindíveis ao trabalho artesanal;

III - a integração da atividade artesanal com outros setores e programas de desenvolvimento econômico e social

IV - a qualificação permanente dos artesãos e o estímulo ao aperfeiçoamento dos métodos e processos de produção;

V - o apoio comercial, com identificação de novos mercados em âmbito local, nacional e internacional;

VI - a certificação da qualidade do artesanato, agregando valor aos produtos e às técnicas artesanais;

VII - a divulgação do artesanato.

Art. $3^{\circ} \mathrm{O}$ artesão será identificado pela Carteira Nacional do Artesão, válida em todo o território nacional por, no mínimo, um ano, a qual somente será renovada com a comprovação das contribuições sociais vertidas para a Previdência Social, na forma do regulamento. 
Art. $4^{\circ} \mathrm{O}$ Poder Executivo é autorizado a criar a Escola Técnica Federal do Artesanato, dedicada exclusivamente ao desenvolvimento de programas de formação do artesão.

Art. $5^{\circ}$ Esta Lei entra em vigor na data de sua publicação.

Em tramitação, desde 2010, no Congresso Nacional, o projeto de lei recebeu, além dessa emenda do Programa de Artesanato Brasileiro (PAB), outras que, também, não foram aceitas.

Havíamos pedido uma reformulação no artigo terceiro que condiciona o artesão a exercer sua profissão somente com as contribuições sociais em dia. Entendemos que isso seria anticonstitucional, mas o artigo não foi alterado (Ellery, depoimento, outubro de 2015).

O PAB pediu, ainda, a suspensão da exigência da escola técnica para o artesão, porque considera que ele não precisa de uma escola técnica para receber capacitação. $E$ que a escolha de se aprimorar ou não deve ser única e exclusivamente do próprio artesão.

Estamos falando de uma arte de ofício, uma arte extremamente tradicional. Pessoas que nascem na comunidade já aprendendo a fazer aquele artesanato. Imagine exigir de um indígena que ele faça uma escola de artesanato (Ellery, depoimento, outubro de 2015).

Para que a lei torne-se efetiva precisa ser regulamentada. Apesar de as alterações propostas pelo PAB não tenham sido acatadas na fase de tramitação da lei, a Secretaria de Micro e Pequena Empresa quer chamar os movimentos sociais, as associações de artesãos para discutir alguns critérios para a regulamentação.

Nossa ideia é tornar algumas questões mais razoáveis como, por exemplo, a escola técnica não ser obrigatória. $E$, em relação ao artigo terceiro, vamos propor alguns parâmetros que caracterizem de fato o artesão e impeçam que outros trabalhadores manuais usufruam dos mesmos benefícios (Ellery, depoimento, outubro de 2015).

Mesmo com a recente sanção pela Presidência da República da lei do artesão, a existência de um Programa do Artesanato Brasileiro, coordenado pela Secretaria de Micro e Pequena Empresa, e de um Plano Setorial do Artesanato, cuja elaboração foi coordenada pelo Ministério da Cultura, as ações políticas em prol do fortalecimento da atividade artesanal ainda parecem descoordenadas no âmbito do governo federal.

Não há uma comunicação entre a gente. Temos pensado e debatido isso com os coordenadores estaduais. Essa falta de comunicação entre os agentes que trabalham com artesanato na esfera federal acontece da mesma forma na esfera estadual. E isso acaba prejudicando o setor (Ellery, depoimento, outubro de 2015).

Além da Secretaria de Micro e Pequena Empresa, do Ministério do Trabalho e Emprego e do Ministério da Cultura, outras pastas do governo federal, também, apoiam o setor do artesanato. O Ministério do Turismo, por exemplo, anunciou, em 2013, investimento de $R \$ 57,4$ milhões para construção e reforma de centros de comercialização 
de artesanato. O Ministério do Desenvolvimento Agrário tem o Programa Talentos do Brasil, que apoia o artesanato rural de base tradicional.

Fica difícil a pessoa que está de fora entender quem coordena a política para o setor dentro do governo e saber qual o programa que se preocupa efetivamente com o desenvolvimento da atividade artesanal. Essa falta de comunicação entre as diversas instâncias federais acaba fazendo com que o artesanato se torne pequeno dentro do governo. São tantas parcelas divididas que a gente não consegue ter números efetivos sobre a economia do setor (Ellery, depoimento, outubro de 2015).

As diversas ações pulverizadas do governo federal fazem, ainda, com que os esforços se tornem repetitivos, beneficiando, muitas vezes, os mesmos artesãos em detrimento de outros. Essa falta de coordenação entre as políticas acaba se refletindo em nível estadual, com várias secretarias trabalhando o mesmo tema.

Provoca, também, uma confusão conceitual.

O Sebrae, que não é um ente federal, trabalha com o mesmo conceito nosso, mas tem outros ministérios que pensam diferente. Pelo menos o conceito deveria ser o mesmo para todos, para que ninguém se confunda, principalmente o artesão. Hoje ele pergunta: Por que sou isso aqui e me enxergam de outra forma em outro lugar? $\mathrm{E}$ aí temos que explicar todo um contexto que é quase inexplicável (Ellery, depoimento, outubro de 2015).

A secretária espera melhorar o diálogo com todos os entes do governo que trabalham com artesanato, depois da reforma ministerial realizada no final de 2015. Desde então, a Secretaria de Micro e Pequena Empresa tornou-se uma secretaria subordinada à Secretaria de Governo da Presidência da República. 


\section{ANÁLISE DE PERCEPÇÃO}

Em nossa análise da relação da pacificação das favelas cariocas com o fortalecimento do empreendedorismo social, foram escolhidas duas comunidades: a Rocinha e a Santa Marta. A escolha da Rocinha deve-se à existência de uma cooperativa de mulheres artesãs, fundada há 30 anos, chamada Coopa-Roca. Por ser uma cooperativa criada muito anos antes do início do processo de pacificação na comunidade, seu estudo nos possibilitou comparar como era o trabalho antes e depois da UPP se instalar. A Santa Marta foi escolhida por ter sido a primeira favela a ter o programa de pacificação implantado. Esse tempo mais longo de existência do programa nos ofereceu uma análise mais consolidada da relação da pacificação com o empreendedorismo. Nesta segunda comunidade, trabalhamos com o grupo Costurando Ideais.

Nas duas comunidades, aplicamos entrevistas semiestruturadas com as empreendedoras desses grupos, assim como com outros empreendedores que possuem negócios nas duas comunidades e lideranças locais. Nosso objetivo foi levantar, no caso dos dois grupos estudados, as percepções das artesãs sobre as condições do trabalho artesanal, oportunidades e desafios enfrentados no contexto da pacificação. Fizemos, ainda, entrevistas com outros empreendedores e lideranças locais para saber suas percepções sobre os efeitos das UPPs no ambiente dos negócios.

\subsection{SANTA MARTA: CONTEXTUALIZAÇÃO}

A favela Santa Marta está localizada no bairro de Botafogo, em frente a uma de suas ruas de maior circulação, a São Clemente, que liga a praia de Botafogo à Lagoa Rodrigo de Freitas. Sem um limite muito claro demarcado na paisagem, a favela começa em uma das pequenas ruas que passam por trás da Praça Corumbá, em direção ao Morro Dona Marta, que separa os bairros de Botafogo e Laranjeiras. Ali, a favela espalha-se por uma área de $55.540 \mathrm{~m}^{2}$ (TEIXEIRA, [2015]) até o alto, de onde é possível avistar os prédios dos bairros de Botafogo, Humaitá e Lagoa Rodrigo de Freitas. A vista estende-se por cima dos arranhacéus, alcançando um dos mais belos cartões postais do Rio, a Lagoa Rodrigo de Freitas, as praias de Botafogo e de Copacabana. Emoldura, ainda, essa visão, o Cristo Redentor (Figura 17). 


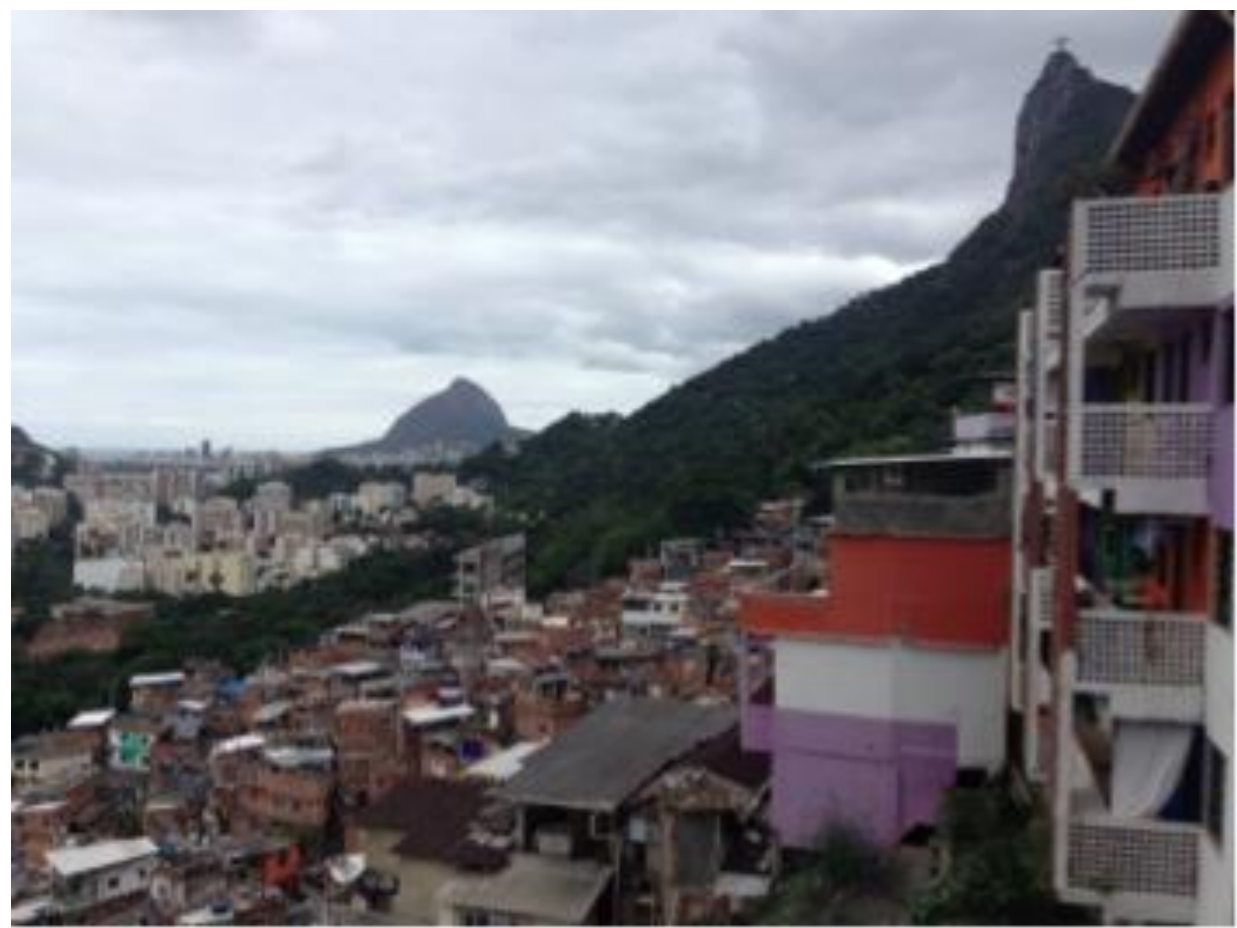

Figura 14 - Favela Santa Marta com Cristo Redentor e o bairro do Humaitá ao fundo.

Fonte: Foto tomada pela autora

A história da comunidade começa nos anos 1920, com a instalação dos operários que trabalharam nas obras de expansão do Colégio Santo Inácio, um colégio católico tradicional de Botafogo. Na época, o Padre Natuzzi permitiu que os operários se instalassem no morro com suas famílias. (TEIXEIRA, [2015]). Muitos desses primeiros moradores haviam migrado da Região Norte e Nordeste do País (CUNHA; MELLO, 2012).

Em seguida, no final desta mesma década, chegou uma leva de agricultores pobres vindos do Vale do Paraíba. Eles fugiam dos efeitos da crise do café no mercado mundial, provocada pela quebra da Bolsa de Valores de Nova lorque (MEIRELLES; ATHAYDE, 2014).

Depois, vieram os nordestinos trazidos pelos fortes movimentos migratórios das décadas de 1940, 1950 e 1960, em direção ao Sudeste. Muitos deles chegavam à Cidade Maravilhosa e iam morar nas favelas. Santa Marta, Rio das Pedras, Prazeres, Rocinha, Maré e Coroa foram as comunidades mais procuradas pelos retirantes (VIVA RIO, [2015]).

Embora seja uma favela muito menor do que a Rocinha ou do que os dois complexos de favelas que existem na cidade (do Alemão e da Maré), a Santa Marta, em 1979, já era considerada a maior das oito favelas do bairro (TEIXEIRA, [2015]). Em 2010, sua população foi estimada em 3.913 habitantes (IBGE, 2010). 
Apesar da proximidade com o $2^{\circ}$ Batalhão da Polícia Militar, a favela é tomada pela violência do tráfico na década de 1980 (SILVA, 2015). A ascensão do narcotráfico na cidade transforma não apenas a vida dos favelados como cristaliza no imaginário coletivo a imagem da favela associada ao crime e à bandidagem (ZALUAR; ALVITO, 2006).

Mesmo com a imagem maculada pela violência, em 1995, a Santa Marta ganha notoriedade internacional, ao ser escolhida para cenário de um videoclipe gravado pelo cantor Michael Jackson (SILVA, 2015). O clipe da música They don't care about us deu nome à laje em que ele foi filmado. Depois o local ganhou uma estátua de bronze, com a imagem do cantor, e um painel de mosaico de pastilhas, criado pelo artista plástico Romero Britto. Atualmente é um dos pontos turísticos mais visitados da comunidade.

No final de 2008, outro acontecimento marcante nessa favela contribui para começar a mudar sua representação social. A Santa Marta é escolhida para receber o projeto piloto das UPPs, a nova política de segurança pública da cidade (ALQUÉRES, 2011, p. 60-72).

Naquele mesmo ano, é inaugurado o plano inclinado ${ }^{19}$ no local, que abre uma nova via de acesso à comunidade (Figura 18). A novidade irá facilitar o dia a dia dos moradores, principalmente daqueles que moram nos pontos mais altos do morro. Atualmente é, também, a porta de entrada de turistas brasileiros e estrangeiros que passaram, com a pacificação, a incluir em seus roteiros um passeio pela favela.

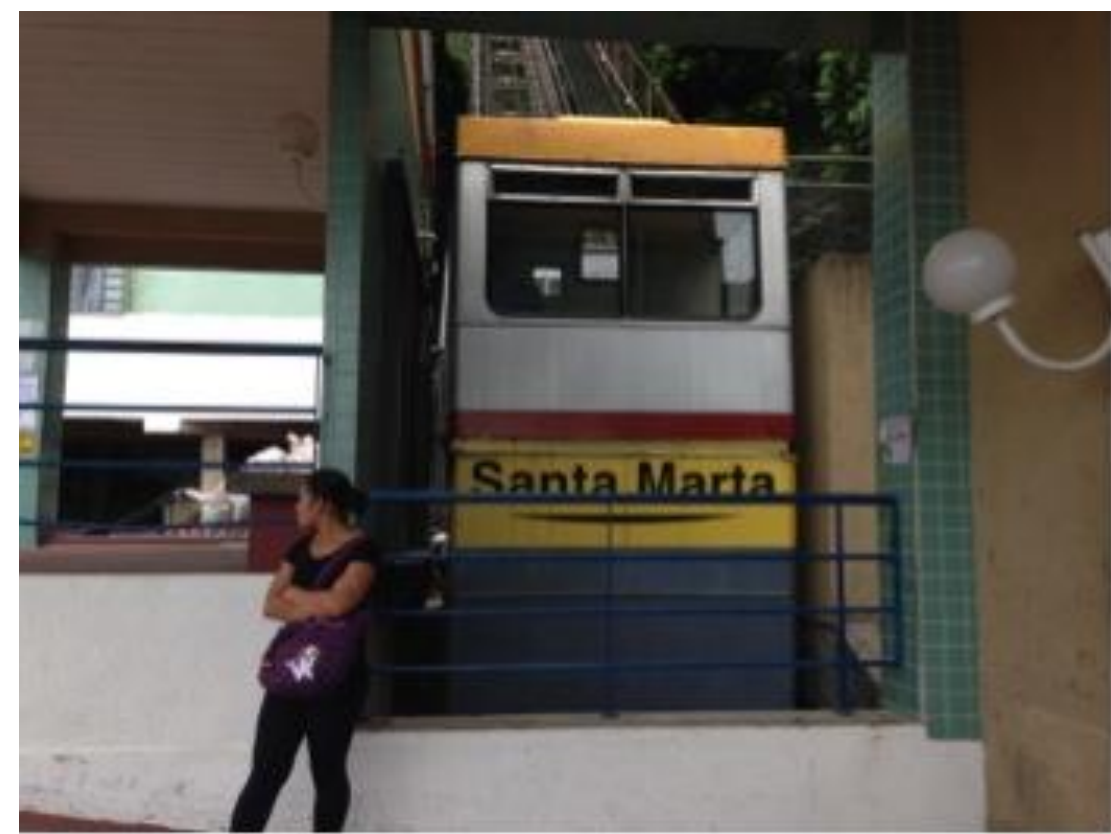

Figura 15 - Bondinho do plano inclinado da favela Santa Marta

Fonte: Foto tomada pela autora

\footnotetext{
${ }^{19}$ O plano inclinado da favela Santa Marta foi construído, em 2008, com cinco estações de bondinho. Os bondinhos funcionam sobre trilhos que correm em duas linhas. A primeira linha faz o trajeto da estação 1 a 3 e a segunda linha, da estação 3 a 5 . O trajeto total leva cerca de 10 minutos.
} 
O turismo é uma das atividades que foram impulsionadas pela nova política de segurança pública. Hoje, é responsável pelo sustento de cerca de $15 \%$ da população na Santa Marta. A estimativa é de Elias Duarte, guia turístico que largou 20 anos de carteira assinada como mecânico para se dedicar ao novo negócio.

"Se alguém falar que tinha turismo antes é mentira. O turismo só veio depois da pacificação. Hoje podemos falar que temos muitas famílias que vivem do turismo. Apesar da crise, estamos conseguindo sobreviver pagando nossas contas, sonhando e almejando um futuro melhor" (Elias Duarte, depoimento, abril 2016).

Elias Duarte é um dos oito guias credenciados pelo Ministério do Turismo que trabalham com turismo na Santa Marta. Juntos eles criaram o Coletivo de Guias Credenciados da Favela Santa Marta e possuem um quiosque na Praça Corumbá, na entrada do morro, para servir como um ponto de divulgação do trabalho deles e de recepção dos turistas. O lema do grupo, segundo a integrante Salete Martins, é "Unidos somos Fortes".

"A ideia é que, independente de sermos de empresas diferentes, moramos e trabalhamos na favela e queremos o melhor do turismo para a favela" (Salete Martins, depoimento abril de 2016).

O quiosque de turismo começou a ser montado pela Secretaria de Turismo do Estado do Rio de Janeiro, com a participação da empresa Coral Tintas, em novembro de 2015. Quando revisitamos o morro em abril de 2016, ele ainda não havia sido oficialmente inaugurado. No entanto, mesmo sem placa e sem material de divulgação sobre os atrativos turísticos da favela Santa Marta, já funcionava a pleno vapor. Enquanto nossa entrevista com Salete transcorria, a todo o momento chegavam turistas, ora para saber sobre o percurso turístico na favela ora para obter informações sobre as opções de hospedagens no morro. No tempo em que estivemos lá, percebemos que a maioria que se dirigia ao quiosque era constituída por turistas estrangeiros.

Salete Martins, além de atuar como guia turístico, é dona da agência de turismo receptivo Favela Santa Marta Turismo, com o marido e mais um sócio. Ela trabalha, ainda, na administração do hostel Bosque Favela Santa Marta, de propriedade de seu marido e mais um sócio. A empreendedora possui, também, um trailer para a venda de açaí na subida do morro. Os negócios estão dando tão certo que, hoje, ela e o marido conseguem viver exclusivamente desses trabalhos desenvolvidos no local onde vivem. O marido, que era técnico da Sky, pediu demissão dessa empresa, em 2011, para se qualificar em turismo e ajudar Salete. 
A ideia de usar o turismo como base para empreendimentos, segundo Salete, surgiu, em 2010, a partir do lançamento do projeto Rio Top Tour na favela Santa Marta. Na inauguração, o então presidente Luiz Inácio Lula da Silva enfatizou a importância de promover a inclusão dos moradores em atividades que aproveitassem o potencial turístico do lugar. Além dele, estiveram presentes sete ministros de Estado; o presidente do Sebrae; os secretários estaduais de Turismo, Esporte e Lazer; de Assistência Social e Direitos Humanos; de Ciência e Tecnologia; o prefeito Eduardo Paes; o secretário de Conservação da Prefeitura e o presidente da Firjan.

O evento mostrou alguns indicativos importantes que marcariam as diferenças entre a nova política de segurança pública, representada pelas UPPs, e as experiências anteriores de policiamento comunitário, apontadas em nosso item 3.5. A presença daquelas autoridades na inauguração ilustrava a cooperação entre os três níveis federativos e o apoio dos empresários à nova política, e sobretudo a integração de outras politicas que pudessem ampliar o acesso à cidadania.

Burgos et al (2011) reconhecem a busca dessa integração, no entanto, nos chamam a atenção para o fato de que com as UPPs a agenda social passaria a estar subordinada à policial.

$$
\begin{aligned}
& \text { "O acesso aos programas sociais e (às) iniciativas de inclusão social, que } \\
& \text { tendem a se desenvolver nas áreas de UPP, fica assim subordinado a uma } \\
& \text { espécie de desconstrução da favela como locus por excelência da } \\
& \text { criminalidade. Assim é que a agenda de acesso a direitos dos moradores de } \\
& \text { favelas passa a se confundir com o discurso da "pacificação" promovida } \\
& \text { pela policialização de territórios populares" (BURGOS et al, 2011, p. 55) }
\end{aligned}
$$

A roupa toda branca usada pelo presidente Lula no dia da inauguração do projeto Rio Top Tour na favela Santa Marta veio, também, em nosso entender, carregada de significados. Como quem flamejava uma bandeira branca, pedindo trégua, Lula parecia direcionar seu pedido principalmente à polícia.

"Polícia tem que vir e aprender a conviver com a comunidade. Não é para subir dar uns tiros e ir embora. O que o governo do Rio de Janeiro está fazendo é fazer com que a polícia conviva com a comunidade" (MENDONÇA, 2010)

A fala do ex-presidente e a cor branca usada por ele no evento, que inaugurava um projeto social na primeira favela a receber uma UPP no Rio de Janeiro, reforçam conclusão de Burgos et al (2011) a respeito do significado da UPP. Ela é antes mais nada uma reorganização da atuação policial nas favelas.

O projeto Rio Top Tour foi fruto de um convênio assinado entre o Ministério do Turismo e a Secretaria de Turismo, Esporte e Lazer do estado do Rio de Janeiro para o 
desenvolvimento de atividades ligadas ao turismo em comunidades carentes. A partir daí foram oferecidos cursos de qualificação para aos moradores.

"Como eu já tinha esse trailer, fiquei interessada. Eles, então, me encaminharam para fazer alguns cursos. O primeiro curso de monitor local de turismo foi realizado aqui na Santa Marta. Depois, foi oferecido o curso técnico em Turismo, que nos capacitava para ser guia turístico, no Colégio Antônio Prado Júnior, uma escola pública no bairro da Tijuca" (Salete, depoimento, abril de 2016).

Em seguida, a Secretaria de Turismo, Esporte e Lazer se subdividiu e o projeto foi para a Secretaria de Esporte, Lazer e Juventude. No âmbito desta secretaria, o projeto desenvolveu ainda, em 2011, um roteiro turístico em outra favela pacificada do Rio de Janeiro, a do Cantagalo. O roteiro leva turistas para conhecer os dois elevadores panorâmicos que ligam a estação do metrô na Praça General Osório, em Ipanema, até o Mirante da Paz, construído no alto do morro. As comunidades do Cantagalo, Pavão e Pavãozinho formam um conjunto de favelas com vista para o mar, situadas no morro entre os bairros de Copacabana e Ipanema, uma das regiões mais valorizadas do Rio de Janeiro. Em 2009, esse conjunto de favelas recebeu, também, uma Unidade de Polícia Pacificadora.

Depois que terminou o curso técnico de Turismo, Salete trabalhou como estagiária no projeto durante dois anos. No terceiro ano, o projeto acabou. "O governador tinha a intenção de expandir esse projeto para outras favelas. Ele foi para o Cantagalo, mas acabou não sendo implantado em outras favelas" (Salete, depoimento, abril 2016)

$\mathrm{Na}$ percepção da empreendedora, existem dois momentos distintos que marcam o ambiente dos negócios na Santa Marta. Um antes e outro depois da pacificação, "quando Lula veio inaugurar o nosso projeto" (Salete, depoimento, abril 2016). A partir daí, ela diz que muita coisa mudou. Essa mudança foi sentida, por exemplo, pela maior presença do Sebrae, do Senac e do Estado na comunidade (Figura 19).

"Antes não havia esse pessoal aqui, não tinham interesse. Eles estão nos ajudando a formalizar os negócios. Hoje podemos dizer que $50 \%$ dos negócios são formalizados por meio do MEI - Microempreendedor Individual" (Salete, depoimento, abril 2016). 


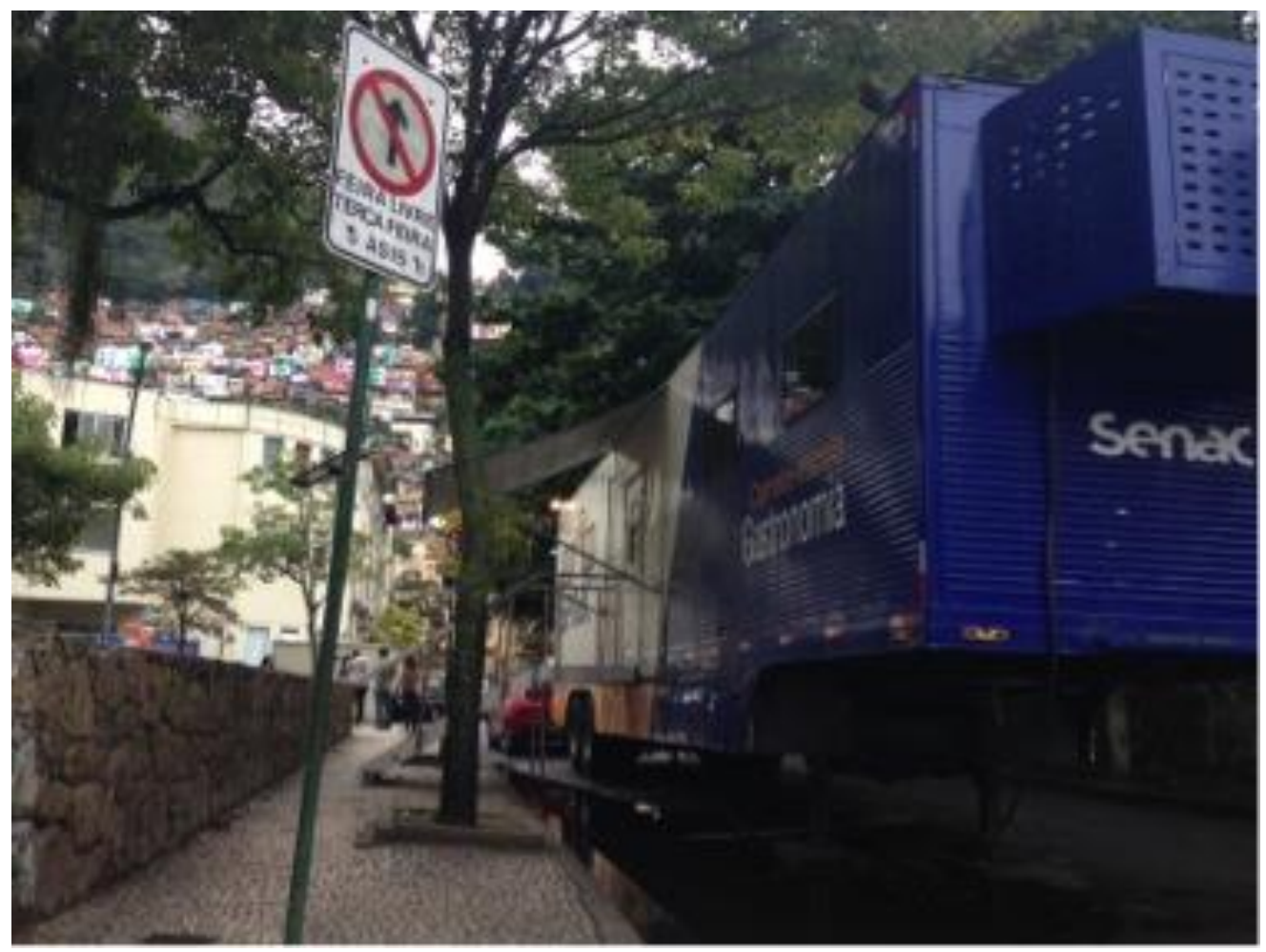

Figura 19 - Carreta-escola do Senac - ao fundo a favela Santa Marta.

Fonte: Foto tomada pela autora

Além da presença de instituições sem fins lucrativos, como Sebrae e Senac, e do Estado, Salete sublinha a participação da iniciativa privada nesse novo momento vivido pela Santa Marta a partir da pacificação. Ela destaca a inauguração de um posto do Bradesco, a inauguração de um escritório da agência de publicidade NBS no morro e o trabalho da Coral Tintas. "Desde 2010, a Coral está aqui pintando e colorindo a favela. Hoje nós somos a favela mais colorida do Brasil" (Salete, depoimento, abril 2016).

Elias concorda que a pacificação trouxe mudanças para a comunidade. "Após a UPP, abriu-se um leque de oportunidades. O governo promoveu o turismo na comunidade, apoiando a realização de cursos, como os do Colégio Antônio Prado Júnior, e o Sebrae ofereceu outros cursos" (Elias, depoimento, abril 2016).

Existem, ainda, na Santa Marta, moradores que trabalham levando turistas para conhecer a favela sem serem credenciados, além de oito guias credenciados pelo Cadastur $^{20}$ na própria comunidade. Eles são chamados monitores ou condutores de turismo. Alguns chegam a empregar pessoas de fora da comunidade para servir como intérprete e oferecer pacotes com transporte até os hotéis como é o caso de Thiago

${ }^{20}$ O Cadastur é um sistema de cadastro do Ministério do Turismo e de órgãos oficiais de turismo nas unidades da Federação, utilizado para cadastrar pessoas físicas e jurídicas que trabalham com atividades relacionados ao turismo. 
Firmino, dono do Santa Marta Tour Favela. Empreendedor com muitas habilidades e ideias concretizadas em diversas frentes de trabalho, Thiago é, ainda, DJ, fotógrafo da vida e da cultura da favela e um verdadeiro agitador cultural. Ele tem, também, um salão de festas na Santa Marta, chamado Lajão Cultural que já recebeu artistas, escritores e diretores de cinema e novelas, tais como a cantora Mart'nália e a atriz Camila Pitanga. De acordo com a divulgação feita no site do Santa Marta Tour Favela, o espaço "tem iluminação computadorizada, laser e, é claro, um ótimo som, fazendo dele o salão de festas mais moderno do Santa Marta".

Os guias turísticos e os monitores locais conduzem seus clientes para a favela, geralmente pelo Plano Inclinado, depois descem com eles pelos becos e vielas, oferecendo-Ihes a oportunidade de conhecer de perto a realidade dos moradores. Com cinco estações, o Plano Inclinado dá acesso a lugares que já se consolidaram como pontos turísticos da favela.

Além da laje do Michael Jackson, acessada a partir da estação 4, os turistas, ao saltarem na estação 3, têm acesso aos prédios coloridos que se destacam no morro, chamando a atenção de quem passa no asfalto, em frente à favela.

\footnotetext{
"Esses prédios foram construídos na época da construção do Plano Inclinado para abrigar as pessoas que moravam em áreas de risco" (Sonia, artesã da Santa Marta, depoimento, abril de 2015).
}

A última estação leva à parte mais alta da favela, onde está atualmente instalada a sede da UPP. Nessa área, estão, também, as casas mais pobres e o "Campinho do Pico", conhecido como o local onde ocorriam os confrontos entre os traficantes e a polícia (CUNHA; MELLO, 2012).

Outro ponto da favela que passou a ser mais visitado após a pacificação foi a quadra da escola de samba Mocidade Unida do Santa Marta. Nos finais de semana, o local é ponto de encontro de rodas de samba, atraindo gente de fora da comunidade. Como indica o site Mapa de Cultura, da Secretaria Estadual de Cultura, outro local que se transformou em um ponto de "balada cult" é a Laje Cultural. O site Favela Santa Marta Tour divulga o local para a realização de festas, oferecendo aos interessados três opções de pacotes. Em todos eles, a vista panorâmica do lugar e a possibilidade de fazer uma festa com preços muito mais vantajosos do que no "asfalto" têm levado a classe média a festejar no morro.

"A pacificação ajudou muito a quebrar o preconceito que havia com a favela. Hoje se paga caro para passar uma noite aqui, para ir às festas. Só filho de bacana" (Sonia, artesã da Santa Marta, depoimento, abril de 2015). 
De acordo com Elias Duarte (2016), atualmente existem em funcionamento quatro hostels na Santa Marta. Além da hotelaria, existem, ainda, empreendimentos ligados à gastronomia, ao artesanato, e atrações como a capoeira e a bateria da escola de samba . "Todos agregam valores que fazem com que o turista quando visita nossa comunidade movimente a economia local" (Elias, depoimento, abril 2016).

Toda essa mudança na favela, observada após a pacificação, teve ainda como consequência a abertura de novos caminhos para quem antes a única perspectiva era o mundo do crime. Em nossas entrevistas, tivemos a oportunidade de conhecer um desses personagens que teve sua trajetória marcada pelo envolvimento com o tráfico e mudou de vida, tornando-se um empreendedor na área de turismo. Quando nos relatou a fase difícil que viveu, desligamos o gravador e fechamos o caderno de anotações para preservamos sua identidade. O preconceito é hoje seu grande desafio.

Numa indicação de que apesar da crise econômica no País, agravada a partir de 2015, o turismo na Santa Marta continua demonstrando vitalidade. Quando retornamos à favela em abril de 2016, Elias estava ampliando seus negócios. Comprava a prazo uma van para oferecer aos turistas mais conforto, buscando-os nos hotéis para trazê-los à Santa Marta e, depois, fazer com eles um tour pela cidade. Grande parte do turismo na Santa Marta é constituída por turistas estrangeiros.

Se é inegável que o turismo na Santa Marta é beneficiado por um conjunto de atrações, pode-se dizer que, numa via de mão de dupla, ele ajudou, também, a impulsionar novos empreendimentos. Esse é o caso da loja de artesanato de Andréia Miranda Lopes, localizada no alto do morro, na altura da estação 4 do bondinho.

Atual presidente da Associação de Comerciantes da Santa Marta, Andréia abriu sua loja em 2008, depois da pacificação. "Começamos lá embaixo (na parte mais baixa do morro). Tínhamos um bar ao lado da escola de samba, aí com o turismo mais forte, resolvemos vender souvenires, que nós mesmos produzíamos" (Andréia, depoimento, abril 2016).

No início, ela e o marido fabricaram chaveiros e outros objetos pequenos. Depois o casal resolveu começar a produzir camisetas em silk (Figura 20). Andréia conta que aprendeu as primeiras noções gratuitamente numa loja que vendia material para esse tipo de pintura, no centro da cidade. Em seguida, foi encaminhada por um agente do Sesi, que trabalhava com a comunidade, para um curso de formação na unidade de Artes Gráficas do Senai, no bairro do Maracanã. "Foram três meses indo para o Maracanã com o marido. Quando vimos que a venda desses produtos tinha dado certo, resolvemos abrir a loja" (Andréia, depoimento, abril de 2016). 


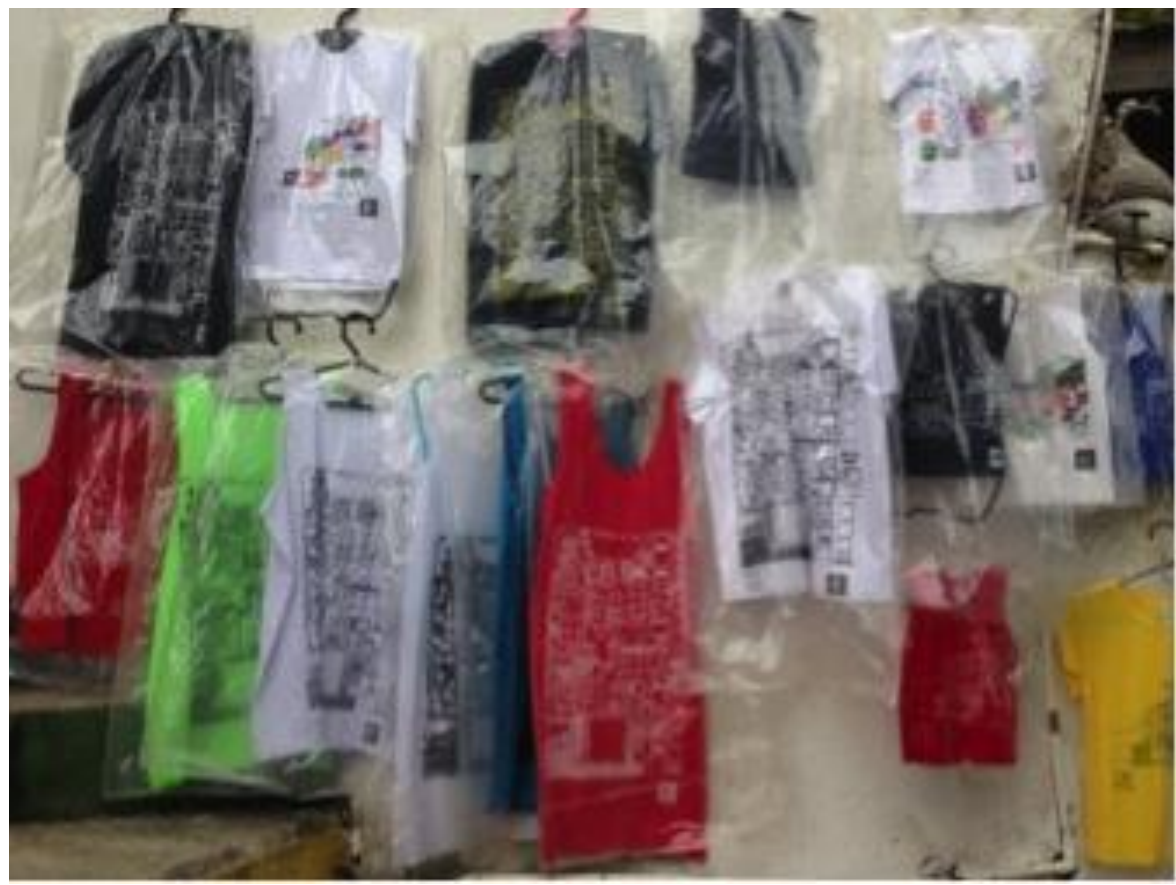

Figura 20 - Camisas em silk - loja Santa Marta Souvenirs de Andréia Miranda.

Fonte: Foto tomada pela autora

Antes de escolher o lugar que iria abrigar sua loja, a empreendedora resolveu acompanhar um tour turístico pela favela com o condutor Thiago Firmino para observar o comportamento dos turistas. "Eu queria um lugar estratégico (Figura 21), onde as pessoas parassem e ficassem" (Andréia, depoimento, abril de 2016).

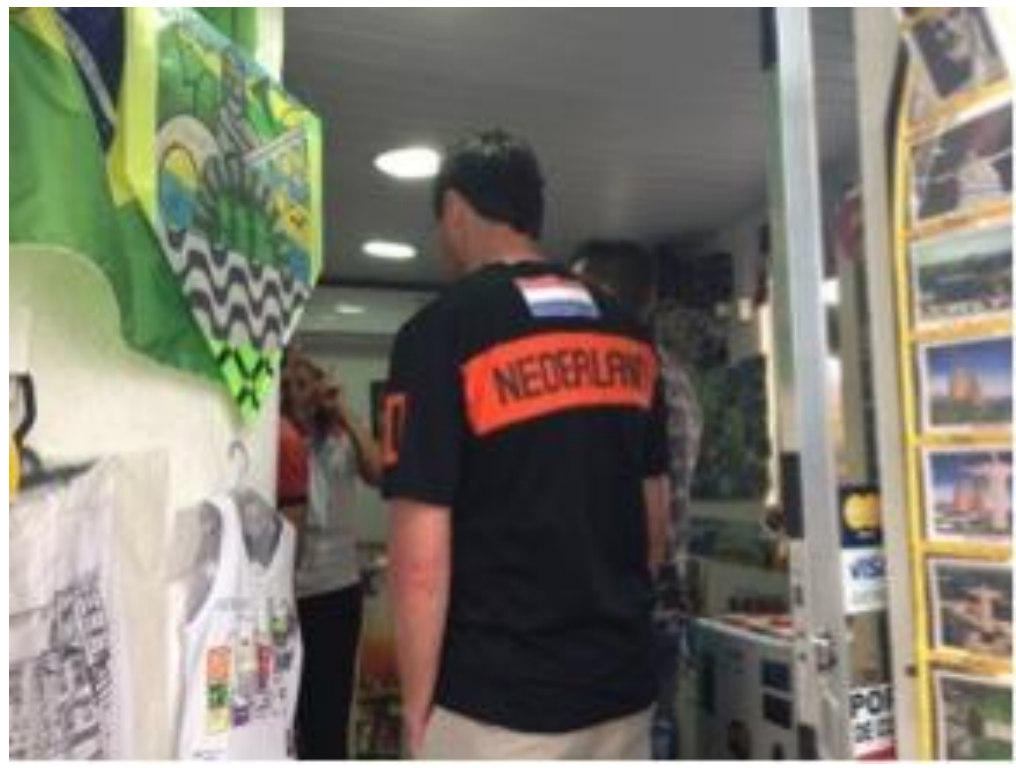

Figura 21 - Turista holandês visitando a loja de Andréia Miranda Fonte: Foto tomada pela autora 
Mãe de seis filhos, dois naturais e quatro sobrinhos que ela cria e considera como filhos, Andréia não podia se dar ao luxo de fazer uma aposta errada. A escolha do lugar não tinha como ter sido mais acertada, na laje onde está a famosa escultura em bronze do cantor Michael Jackson e o mosaico do artista plástico Romero Brito e que funciona como um mirante (Figura 22). O local é um dos pontos altos do tour, onde os turistas param para apreciar a vista que alcança o mar e observar o conjunto de casinhas da comunidade.

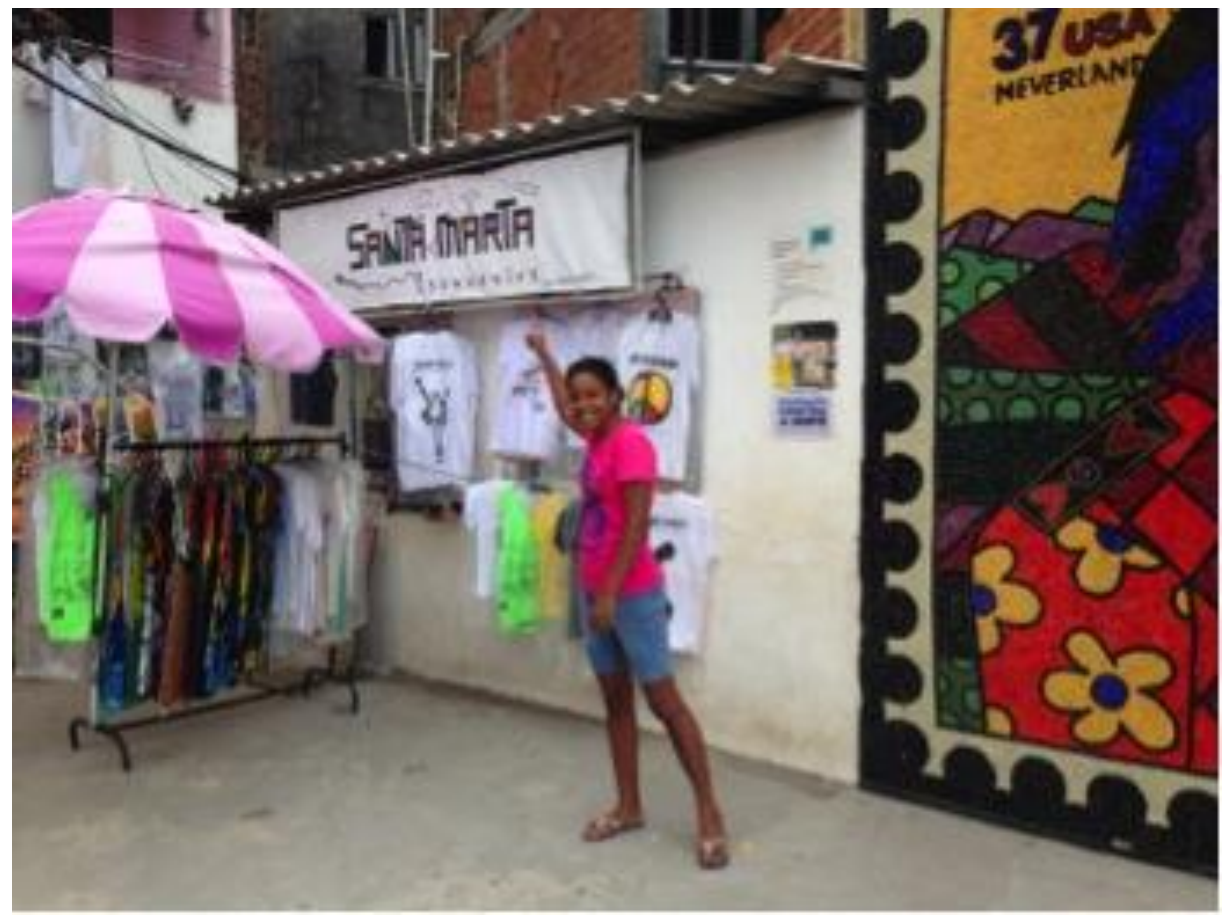

Figura 16 - Loja de souvenirs de Andréia Miranda ao lado do mosaico de Romero Brito.

Fonte: Foto tomada pela autora

Nos períodos de Natal, Reveillon, Carnaval e férias escolares as vendas são maiores, mas Andréia (2016) garante que durante o ano todo o negócio "tem fluxo". Ela, também, atesta que "a grande movimentação do empreendedorismo veio a partir da pacificação. Antes eram mais bares e lanchonetes e não tinha gente de fora" (Andréia, depoimento, abril 2016)

O novo empreendimento, hoje, Ihe propicia renda suficiente para o sustento de sua família. O marido largou o emprego de porteiro para ajudá-la. No final de semana, os filhos mais velhos ajudam também. Andréia emprega, ainda, uma intérprete que não mora na favela para fazer o atendimento aos turistas estrangeiros e diz que um de seus seis filhos já está se virando no inglês (Figura 23). 


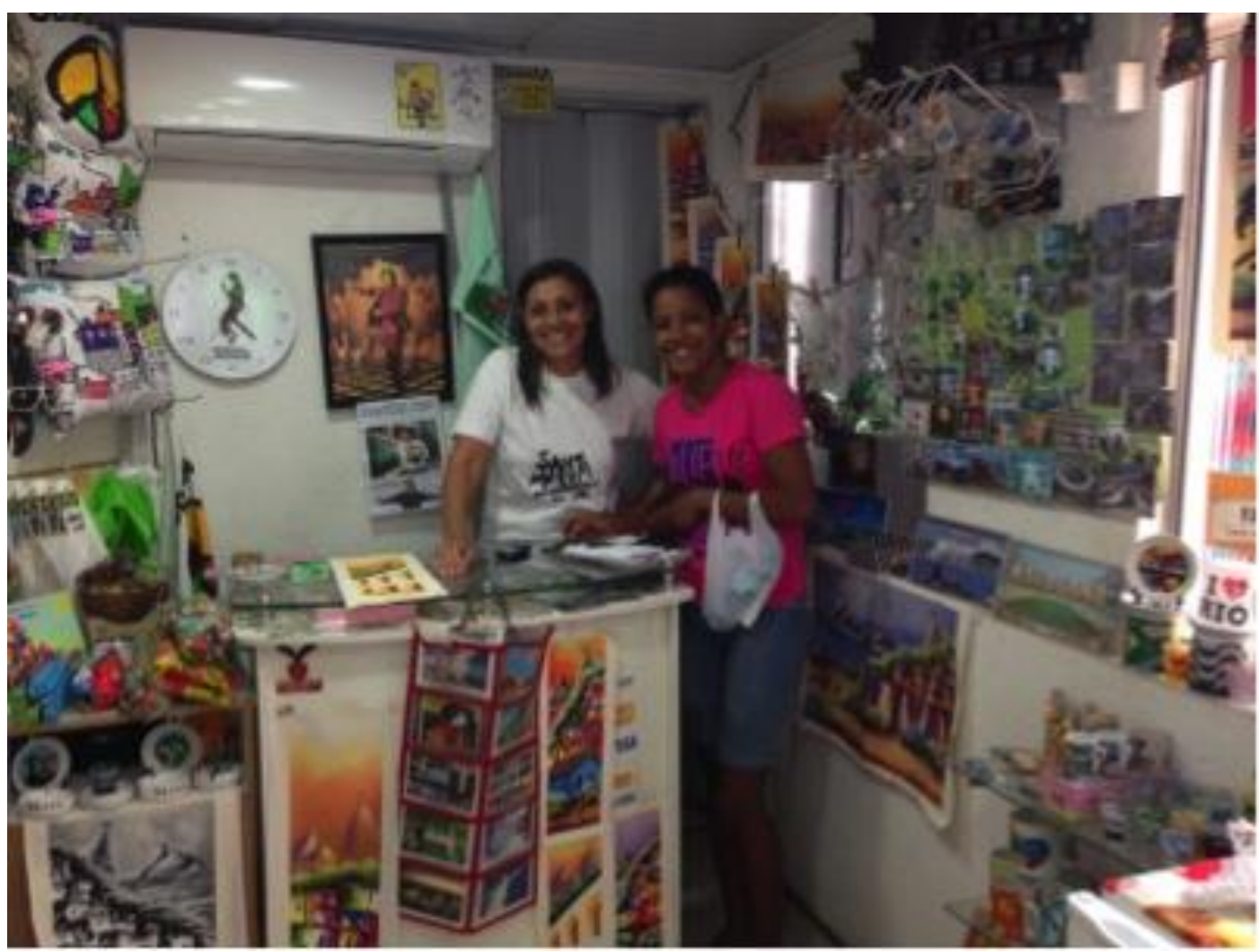

Figura 23 - Andréia Miranda (à direita) em sua loja da favela Santa Marta e sua funcionária intérprete.

Fonte: Foto tomada pela autora

Dos objetos expostos na loja, Andréia (2016) explica que 90\% são produzidos na favela Santa Marta. Ela e o marido produzem bolsas, almofadas e camisetas pintadas. Destaca-se, ainda, a produção de mais dois artesãos: Fiel e Gerônimo. Fiel é um rapper famoso da comunidade que produz bonés e já tem uma marca própria com seu nome. Gerônimo é um pintor que morou na favela do Pavão-Pavãozinho e, embora tenha descido para o "asfalto", continua pintando telas sobre a paisagem das favelas cariocas.

Além de Andréia Miranda, outras artesãs na Santa Marta, também, sentiram uma mudança no ambiente dos negócios a partir da instalação da UPP na favela. Esse é o caso do grupo de costureiras e bordadeiras Costurando Ideais.

\subsubsection{Costurando Ideais}

O grupo Costurando Ideais faz parte da Rede Santa Marta de Economia Solidária, que reúne seis microempreendimentos de gastronomia e artesanato, e da Rede Cooperativa de Mulheres Empreendedoras da Asplande, uma organização não governamental que apoia iniciativas para promover o empreendedorismo de mulheres residentes em comunidades de 
baixa renda. A instituição é filiada à Associação Brasileira de Organizações Não Governamentais e à Rede ASHOKA, rede internacional de apoio ao empreendedorismo social.

Sonia Maria de Oliveira (Figura 24) é uma das fundadoras do Costurando Ideais. Por trás do seu sorriso largo e de sua postura decidida diante da vida, há uma história marcada por muita luta e sofrimento. Perdeu o marido assassinado, quando seus filhos ainda eram crianças, a mais nova tinha apenas 2 anos e os outros dois, 4 e 10 anos. Sonia precisou criar os três filhos sozinha.

Liderança forte no morro, ela sempre se envolveu com questões que pudessem trazer algum tipo de melhoria para o desenvolvimento do lugar. Ajudou a montar uma escola de música clássica no morro com a mãe de uma aluna da Escola Alemã Corcovada, uma escola de classe média alta, cujo fundo do terreno faz limite com a favela. "Montamos essa escola em uma sala da Igreja Batista, mas depois o lugar ficou pequeno. Mudamos, então, para o prédio de três andares localizado no alto do morro" (Sonia, artesã da Santa Marta, depoimento, abril de 2015).

O prédio havia sido construído pelo governo do estado para ser uma creche. No entanto, a ideia não saiu do papel, pois as mães tinham medo de colocar seus filhos lá. O lugar estava localizado em uma área de confronto entre traficantes e a polícia. "Hoje nós cedemos o prédio para a instalação da UPP e transferimos a escola de música para o morro da Babilônia, no Leme" (Sonia, artesã da Santa Marta, depoimento, abril de 2015).

Com o anúncio da chegada da UPP, Sonia liderou o movimento para a instalação de um Posto de Saúde para atender a comunidade.

Eu era auxiliar de enfermagem, fazia parto de madrugada e cuidava de quem recebia tiro. Na época que trouxeram a pacificação para o morro, o Secretário de Segurança José Mariano Beltrame e o pessoal da UPP fizeram uma reunião com as lideranças locais para explicar como iria funcionar a pacificação. Aí falei que precisávamos de um posto de saúde. Em 2009, inauguramos o posto na Praça Corumbá (Sonia, depoimento, abril de 2015).

Seu envolvimento com a economia solidária vem desde 1995.

Nosso trabalho era um movimento social, na época se falava em cooperativismo. Começamos a nos reunir com o pessoal do IBASE, que fomentava esse movimento. Conheci Betinho. A partir do cooperativismo, passamos a falar de Economia Sustentável, Comércio Justo (Sonia, artesã da Santa Marta, depoimento, abril de 2015). 


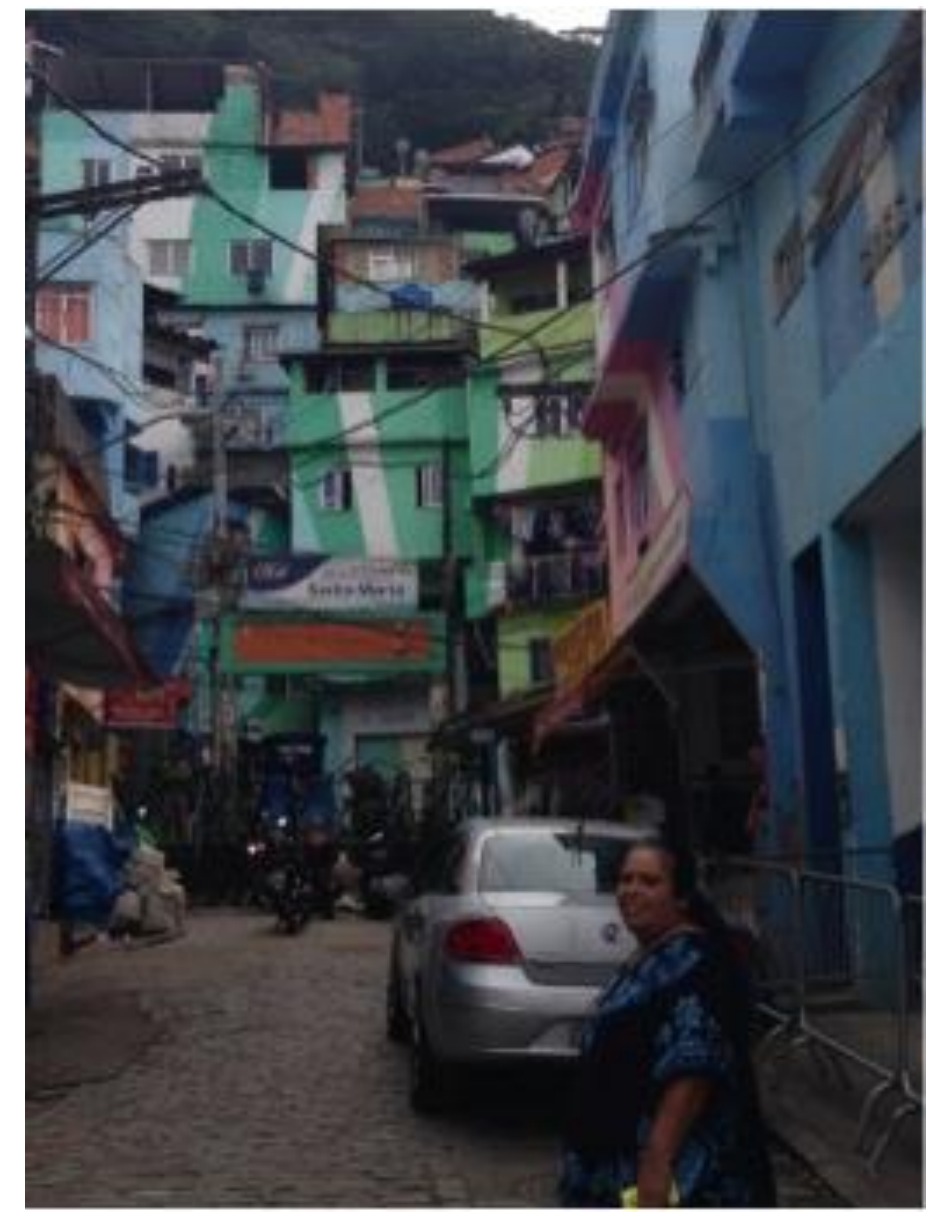

Figura 17 - A costureira Sonia Maria de Oliveira e a favela Santa Marta.

Fonte: Foto tomada pela autora

Sonia trabalhava como auxiliar de enfermagem. Quando dormia nos plantões dos hospitais, ficava preocupada com os filhos, pois a comunidade era muito violenta.

Tinha dias em que a gente acordava e dava de cara com um corpo estendido na porta de casa. Então, eu resolvi largar esse trabalho e passei a trabalhar em casa. Eu bordava e costurava. (Sonia, artesã da Santa Marta, depoimento, abril de 2015).

Ao invés de trabalhar sozinha, Sonia resolveu unir forças.

Juntamos um grupo de mulheres que tinham a mesma preocupação. $O$ padre cedeu um espaço na igreja e aí passamos a nos reunir e fazer peças de fuxico, capas de almofada, bolsas e com essa produção passamos a sustentar nossos filhos. (Sonia, artesã da Santa Marta, depoimento, abril de 2015).

A produção era vendida dentro da própria comunidade e em feiras de gêneros alimentícios. Em 2000, o grupo recebeu apoio da organização não governamental Viva Rio. Criada em 1993, ela reunia "representantes de vários setores da sociedade civil como resposta à crescente violência que assolava o Rio de Janeiro" (VIVA RIO, [2015]). Em seus 
mais de 20 anos de atuação, notabilizou-se pelo apoio a projetos de promoção da paz e da inclusão social.

Com a ajuda do Viva Rio, o grupo de mulheres conseguiu as primeiras máquinas de costura industrial por meio do Consulado Francês.

O Viva Rio trouxe as camisetas do Rock in Rio para a gente fazer, mas as nossas máquinas não faziam o acabamento. Era preciso (ter uma máquina que fizesse) o overlock. Aí, o Viva Rio trouxe as primeiras máquinas. Ao todo, quatro: duas de overlock, uma reta e uma colarete para bainha (Sonia, depoimento, abril de 2015).

Depois que o grupo ganhou as máquinas, as mulheres procuraram capacitar-se.

As máquinas chegaram, mas ninguém sabia usá-las. E aí fomos atrás de capacitação. Fizemos um curso de Gestão com o Fundo Afro Ivanildo Ribeiro, e depois o IDACO, uma organização não governamental, pagou uma professora que nos capacitou no corte e na costura e no uso das máquinas (Sonia, depoimento, abril de 2015).

A vinda das novas máquinas profissionais e os cursos de capacitação possibilitaram que as mulheres usassem o conhecimento e a habilidade que tinham de costura e bordado em uma atividade profissional. A partir daí, elas passaram a aceitar encomendas e começaram a fabricar camisetas escolares. Para marcar a nova fase, as mulheres batizaram o grupo com o nome Costurando Ideais.

Nesta época, éramos oito mulheres. Depois, teve época que chegamos a
ser 20 . Importante dizer que o grupo sempre foi um multiplicador,
capacitando as mulheres da comunidade na costura, no bordado, no
reaproveitamento de material e no patchwork. (Sonia, costureira,
depoimento, abril de 2015).

Atualmente, Sonia trabalha com Antônia, Marisa e Marisete. Apesar de morar numa área fronteiriça da Santa Marta, Marisete sente-se totalmente integrada à vida da favela. Filha de um dos primeiros presidentes do Morro da Esperança, localizado no Complexo do Alemão, ela foi criada dentro dessa realidade. Atualmente, vive em um apartamento conjugado na entrada do Morro Dona Marta. O local, um misto de moradia e oficina de trabalho, foi fonte de inspiração para o nome do outro empreendimento que Marisete participa com mais duas pessoas, o Janela Carioca, e funciona como ateliê dos dois grupos (Figuras 25 e 26). "Da minha janela eu vejo tudo, tudo passa por debaixo dela. Fico na entrada da comunidade, de frente para o Cristo" (Marisete, depoimento, abril de 2015). 


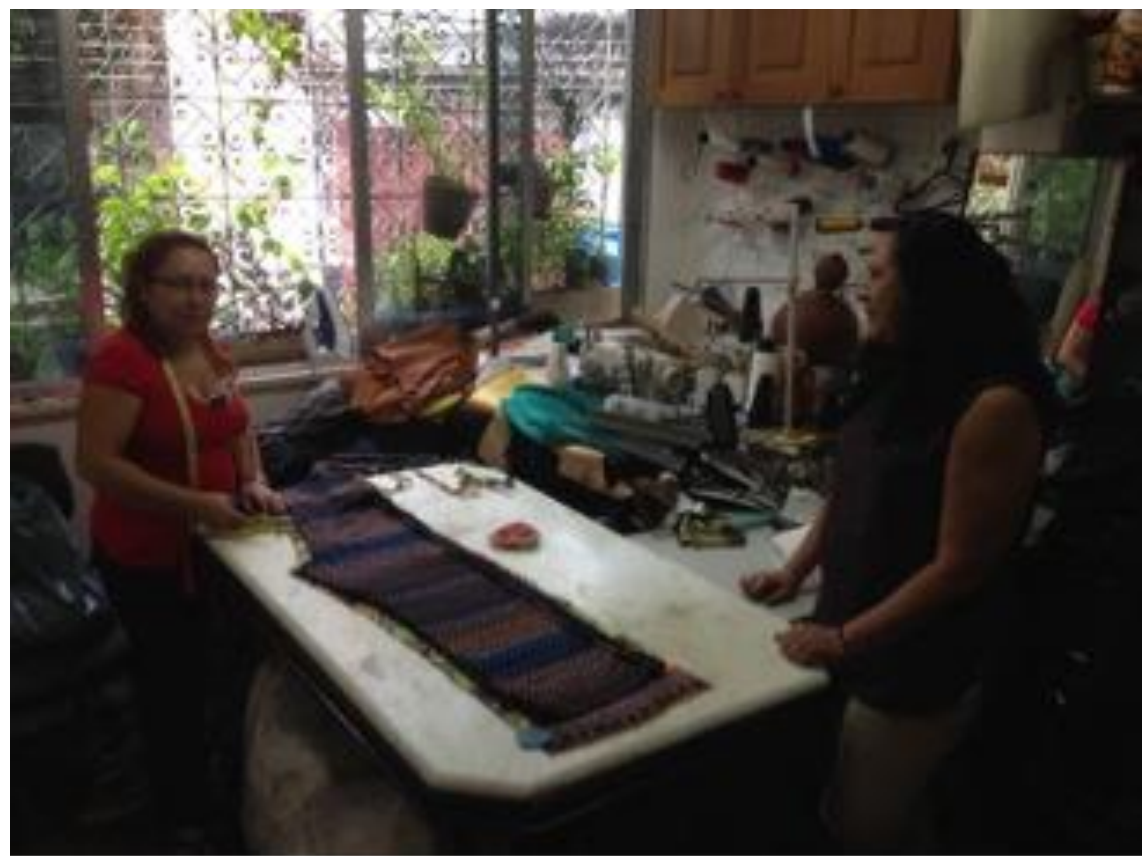

Figura 18 - Local de trabalho do grupo Costurando Ideais.

Fonte: Foto tomada pela autora

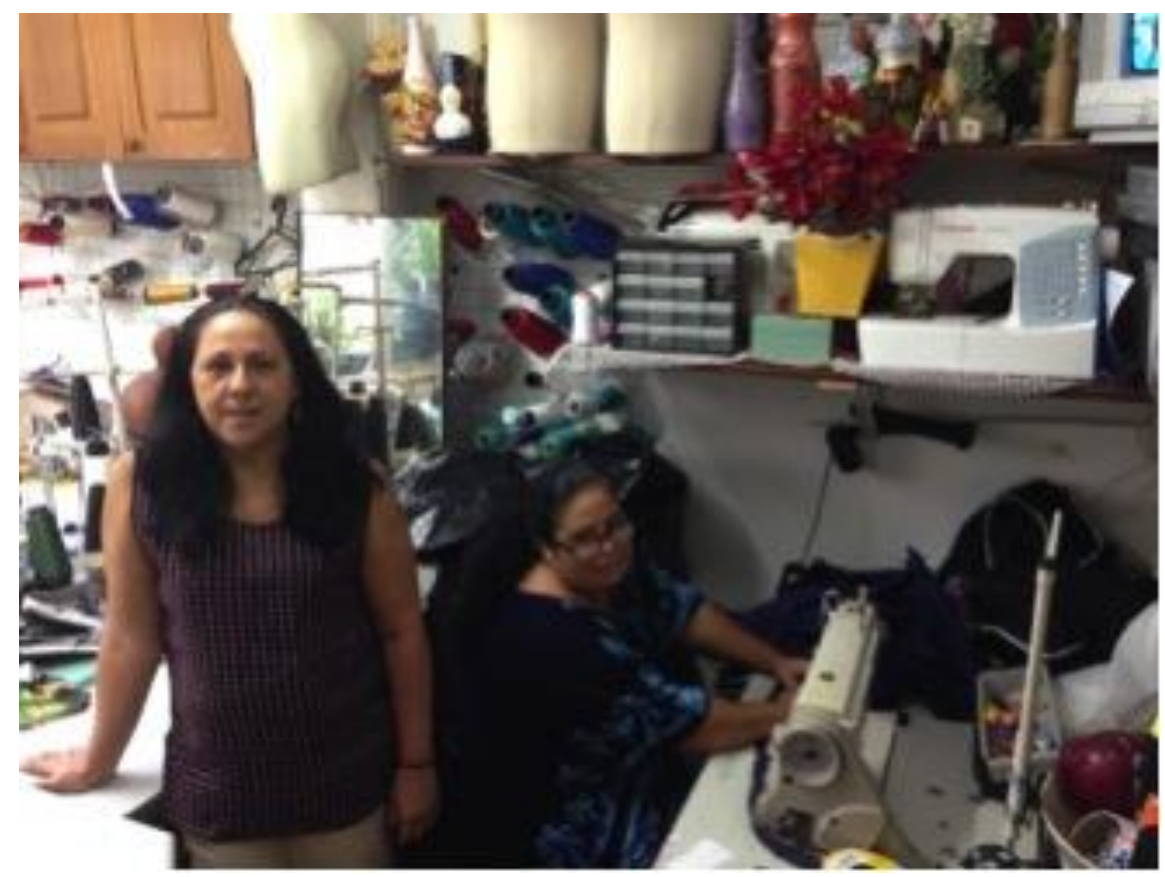

Figura 26 - Marisete Gomes e Sônia Maria de Oliveira, do Costurando Ideais.

Fonte: Foto tomada pela autora

A história do Janela Carioca, mais recente do que a do Costurando Ideais, tem suas raízes no conhecimento e na habilidade antigas de Marisete.

Sempre tive costura na minha casa, formei meus dois filhos com esse trabalho. Há seis anos, eu e mais duas costureiras de comunidades, uma delas da Santa Marta, fomos convidadas como bordadeiras a participar da 
Fashion Week, no Jardim Botânico. A partir daí, surgiu a ideia de montar o ateliê. Eu já tinha o espaço (Marisete, depoimento, abril de 2015).

Depois de formalizar o novo negócio, como microempreendedora individual (MEI), Marisete passou a poder emitir nota fiscal e viu as possibilidades de comercialização ampliarem-se.

Com a pacificação, percebemos a oportunidade de criar produtos para os turistas que começaram a chegar. Daí tivemos a ideia de juntar o Costurando Ideais com o Janela Carioca (Marisete, depoimento, abril de 2015).

A ideia de fazer produtos para os turistas (Figuras 27 e 28) que passaram a visitar a favela foi proposta pelo Sebrae.

O Sebrae sugeriu que desenvolvêssemos um produto com a cara da comunidade. Entramos, então, neste projeto que aconteceu quase em paralelo com outro da Firjan, com o tecelão e designer Renato Imbrosi. A Firjan já tinha o projeto Cozinha Brasil, que trabalhava com alimentação saudável e aproveitamento de talos e queria fazer com o Renato Imbroisi um catálogo com produtos feitos pela comunidade (Sonia, depoimento, abril de 2015).

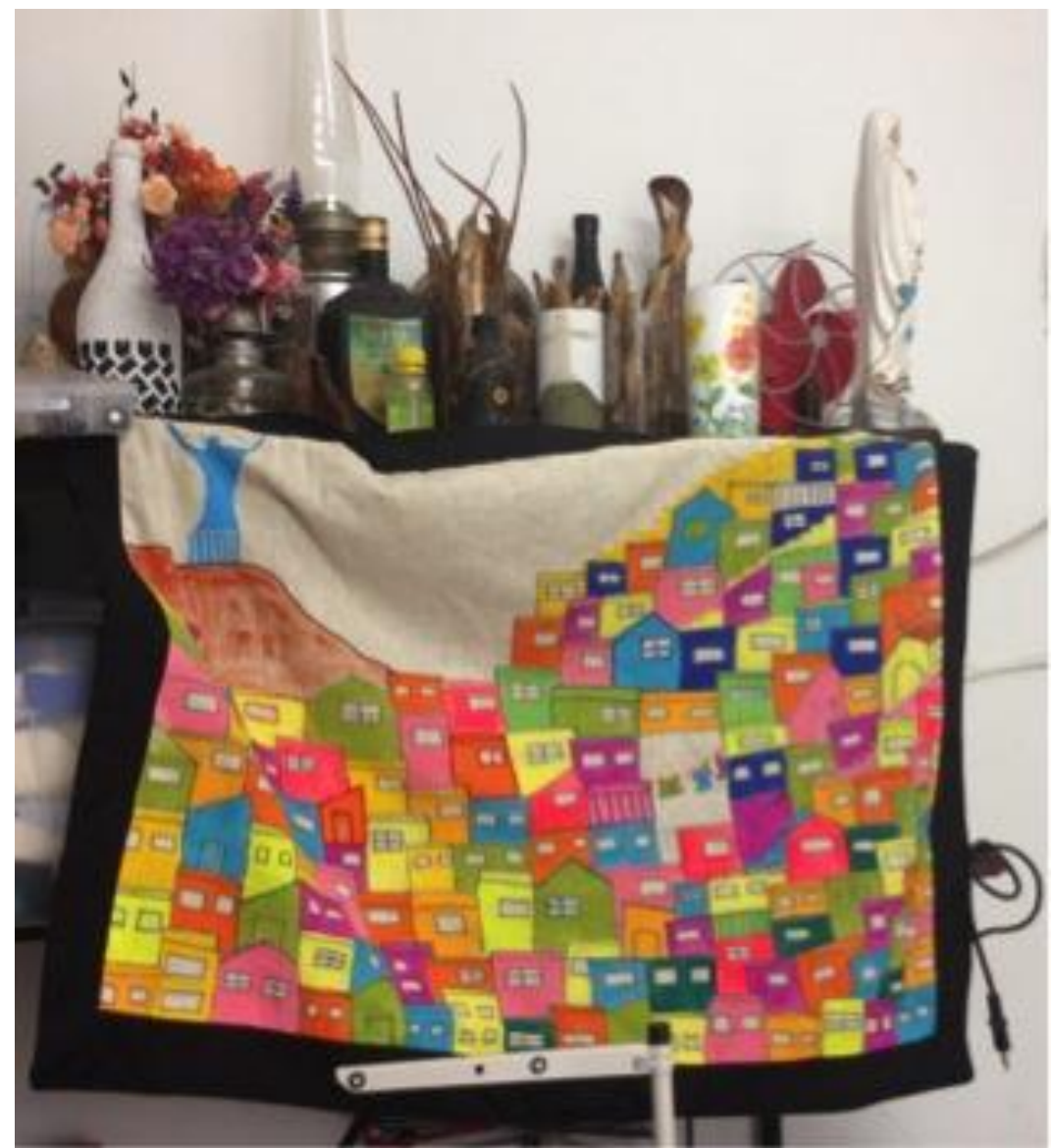

Figura 27 - Painel pintado à mão pelo grupo Costurando Ideais

Fonte: Foto tomada pela autora 
Para concretizar a proposta do Sebrae, as costureiras contaram com o apoio da agência de publicidade NBS, que havia aberto um escritório dentro da comunidade e lançado o movimento Rio + Rio. Esse escritório mantinha-se no local até a data de realização dessa pesquisa.

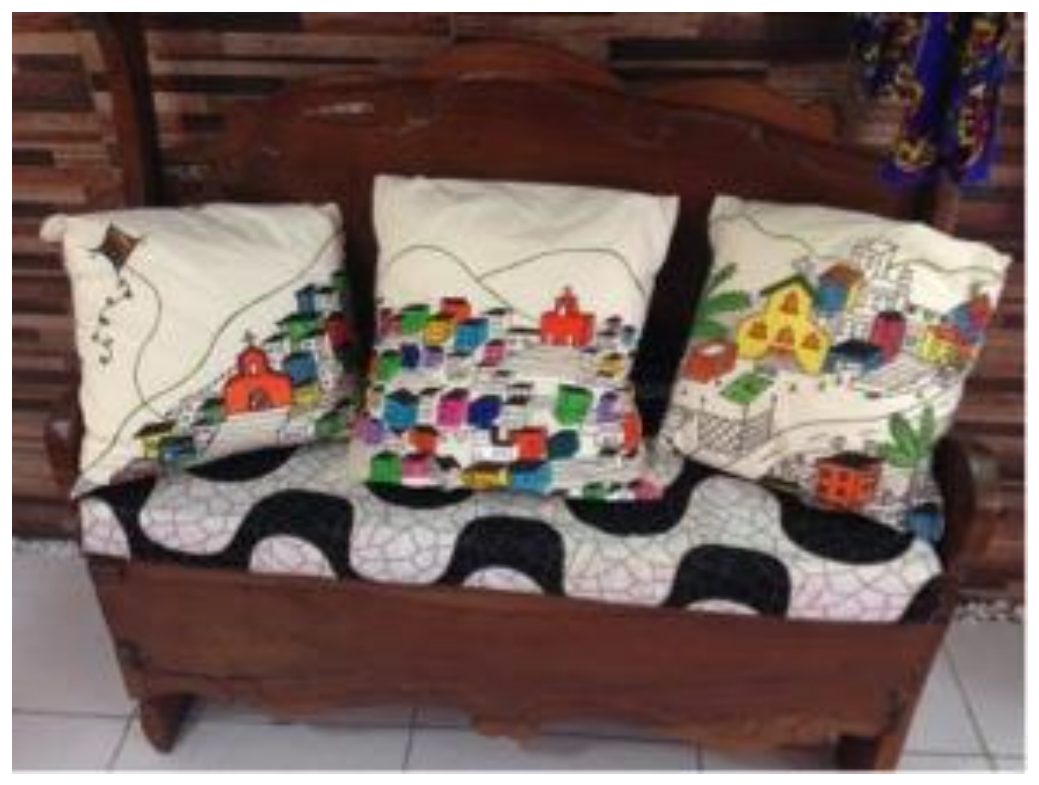

Figura 28 - Almofadas produzidas pelo grupo Costurando Ideais

Fonte: Foto tomada pela autora

O movimento Rio + Rio, quando lançado, em 2012, em forma de manifesto, convocava os empresários a participar do novo momento que a cidade estava passando. O objetivo era buscar o apoio das grandes empresas privadas para projetos de empreendedorismo nas favelas pacificadas do Rio.

\begin{abstract}
A ideia (do Rio + Rio) surgiu dentro da agência NBS, com a missão de aproveitar o bom momento da cidade. Acreditamos no projeto de pacificação e entendemos que sociedade e iniciativa privada precisam assumir seu papel nesse momento de virada. ${ }^{21}$ (site do projeto).
\end{abstract}

O resultado dessa parceira com o Sebrae e com a NBS foi o lançamento, em 2014, da primeira coleção da marca Santa Marta We Care, com uma linha de produtos inspirada na comunidade. A agência assinou a criação da logomarca e forneceu verba para a compra de matéria-prima. Ao todo, foram produzidas 600 peças para essa coleção. Cangas, camisetas, bolsas e até biquínis foram quase todos vendidos no dia do lançamento, realizado na sede da agência de publicidade no morro.

Outra prova da habilidade e do talento dessas mulheres pode ser conferida no museu A Casa, em São Paulo, para onde elas enviaram um painel com bordado e pintura.

\footnotetext{
${ }^{21}$ Disponível em: <http://riomaisrio.tumblr.com/post/74979292140/nbs-rio-rio-lan\%C3\%A7acole\%C3\%A7\%C3\%A3o-no-santa-marta\#.VstnKPkrLIU>. Acesso em: 3/3/2015.
} 
Atualmente, elas vêm se dedicando à produção de camisetas, bolsas, toalhas de mesa, jogos americanos e toalhas de copa. E estudam a possibilidade de juntar os empreendimentos em apenas uma logomarca.

Os produtos são comercializados em eventos como, por exemplo, a Feira de Orquídeas ou feiras como a Rio Ecosol. "Já participei do Fashion Rio, do Fashion Business e de um evento na França, representado a moda brasileira" (Marisete, depoimento, abril de 2015).

Em abril de 2015, Sônia disse que a atividade permitia retorno mensal entre $R \$$ $1.000,00$ a $\mathrm{R} \$ 2.000,00$ por mês. Com o dinheiro, ela sustentava sua família. "Mas tem mês que não dá isso. No início do ano, por exemplo, só conseguimos tirar um salário. Depois melhora" (Sonia, depoimento, abril de 2015).

Mesmo com a participação em feiras e eventos, as empreendedoras dizem que o escoamento da produção é, ainda, a maior dificuldade. "Para participar das feiras e dos eventos, temos que participar, também, das reuniões (preparatórias) e, com isso, falta tempo para a produção" (Sonia, depoimento, abril de 2015).

Apesar desses problemas, Marisete e Sonia apostam na potencialidade das atividades manuais e artesanais. Na opinião delas, tal potencialidade reside, principalmente, na possibilidade de o trabalho poder ser desenvolvido em rede. "A troca de experiências intensifica o aprendizado e os laços entre as mulheres" (Sonia, depoimento, abril de 2015).

Em relação à pacificação, ambas estão convencidas que esta contribuiu muito para os negócios (Figura 29). "Hoje, as pessoas vêm sozinhas aqui, não precisam mais ligar para avisar" (Sonia, depoimento, abril de 2015). "Se o morro não tivesse sido pacificado, não teríamos a visibilidade que tivemos para o nosso trabalho" (Marisete, depoimento, abril de 2015). 


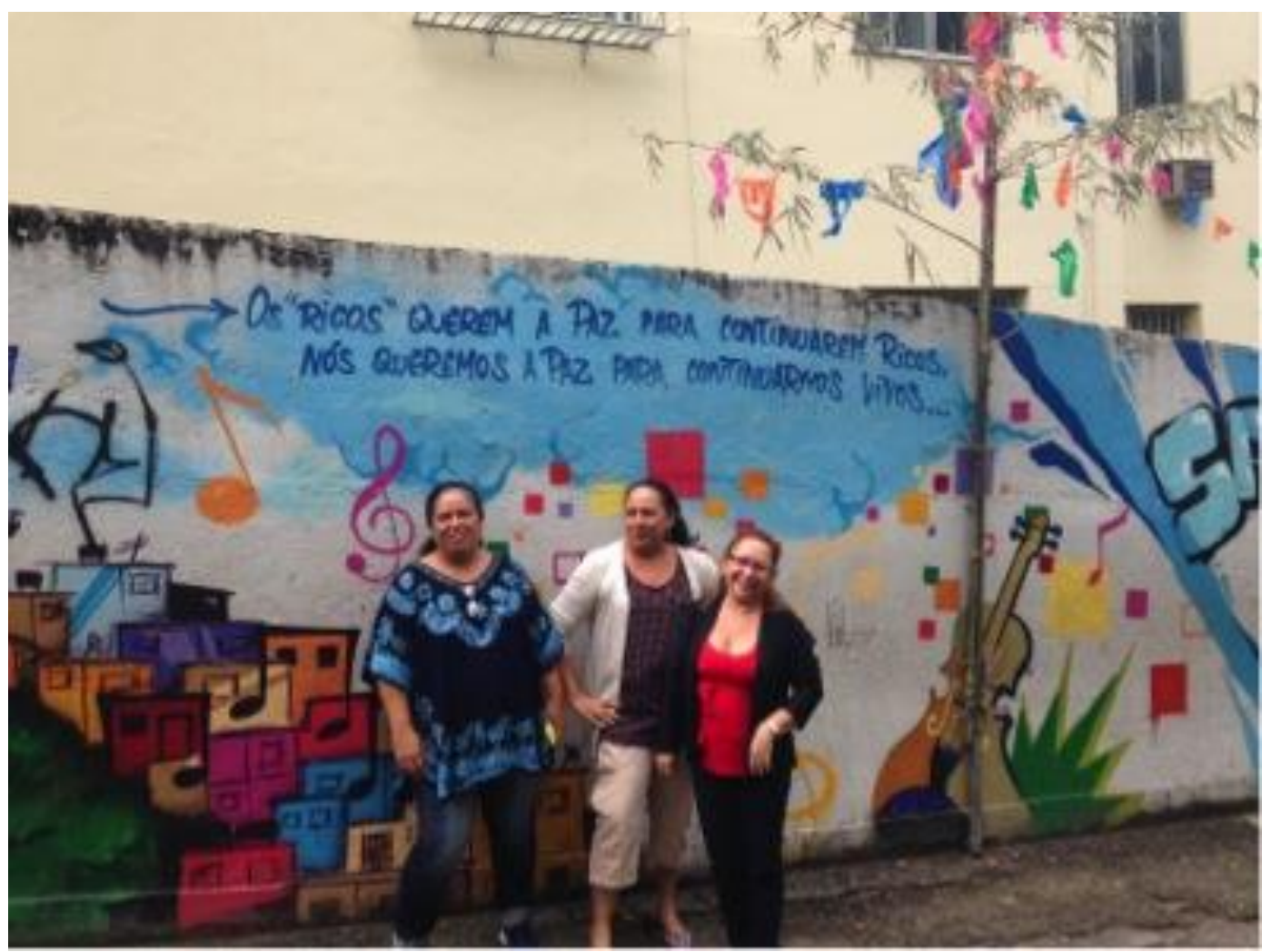

Figura 29 - Sônia, Marisete e Mariza do grupo Costurando Ideais da favela Santa Marta

Fonte: Foto tomada pela autora

No caso da Santa Marta, a pacificação contribuiu para o empreendedorismo, sobretudo, ao abrir a comunidade para a visitação turística. Em função do turismo, foram inaugurados hostels, criados tours pela favela, moradores foram qualificados como guias e monitores turísticos, e desenvolvidos produtos artesanais voltados a aproveitar aquele novo mercado consumidor. A mudança no ambiente do morro possibilitou relações mais permeáveis entre a favela e a cidade, ao trazer turistas e moradores da cidade para circularem em suas vielas e consumirem o que a favela produz. Além disso, contribuiu, também, para um fortalecimento do capital social da favela. Hoje moradores se unem para continuar a desenvolver o turismo no local. Mesmo trabalhando de forma independente, não necessariamente em torno de uma associação ou cooperativa, cada um acaba fortalecendo o trabalho do outro, seja divulgando o hostel de alguém, levando turistas para conhecer o artesanato produzido no local, costurando e bordando juntos ou se revezando no quiosque de turismo para receber os visitantes.

Considerada favela 'modelo', por ter sido a primeira favela a ser pacificada, a Santa Marta, em maio de 2015, presenciou um tiroteio entre traficantes e policiais, que assustou seus moradores. O incidente mostrou que o processo de pacificação não estava tão consolidado assim. Embora tenha trazido paz e essa sensação de paz tenha estimulado o 
empreendedorismo no local, o acontecimento, logo controlado pela polícia, serviu para mostrar que o processo de pacificação não é tão imediato assim. Como diz Sonia, "é preciso que o Estado esteja atento para a violência não voltar".

\subsection{ROCINHA: CONTEXTUALIZAÇÃO}

A Rocinha está localizada no Morro Dois Irmãos, sobre o túnel Zuzu Angel, que liga dois bairros de classe média alta do Rio de Janeiro - Gávea e São Conrado. De acordo com trabalho de interpretação de ortofotos, realizado pelo Instituto Municipal de Urbanismo Pereira Passos, sua área de ocupação era de $849.107 \mathrm{~m}^{2}$ em 2011. Esse valor mostra uma retração no seu crescimento espacial de, aproximadamente, $-2,7 \%$ no período de 2008 a 2011, devido às remoções em áreas limítrofes da favela.

No entanto, apesar dessa retração na expansão espacial, a Rocinha continuou a crescer verticalmente. Entre 2000 a 2010, foi a favela que mais cresceu entre as favelas consideradas bairros (Figuras 30 e 31). Sua taxa de crescimento populacional, no período, foi de $23 \%$. Essa taxa de crescimento ultrapassou, também, a da cidade do Rio de Janeiro, que registrou 7,9\% na mesma década. Com uma população estimada em 69.161 habitantes (IBGE, 2010), a Rocinha é conhecida como a maior favela brasileira.

Com características topográficas muito diferentes de outras grandes favelas do Rio de Janeiro, como os Complexos de favelas do Alemão e da Maré ou a favela Rio das Pedras, a Rocinha é uma favela extremamente íngreme, com barracos superpostos na paisagem até sua porção mais alta. Apresenta, também, construções de prédios de até 11 andares. 


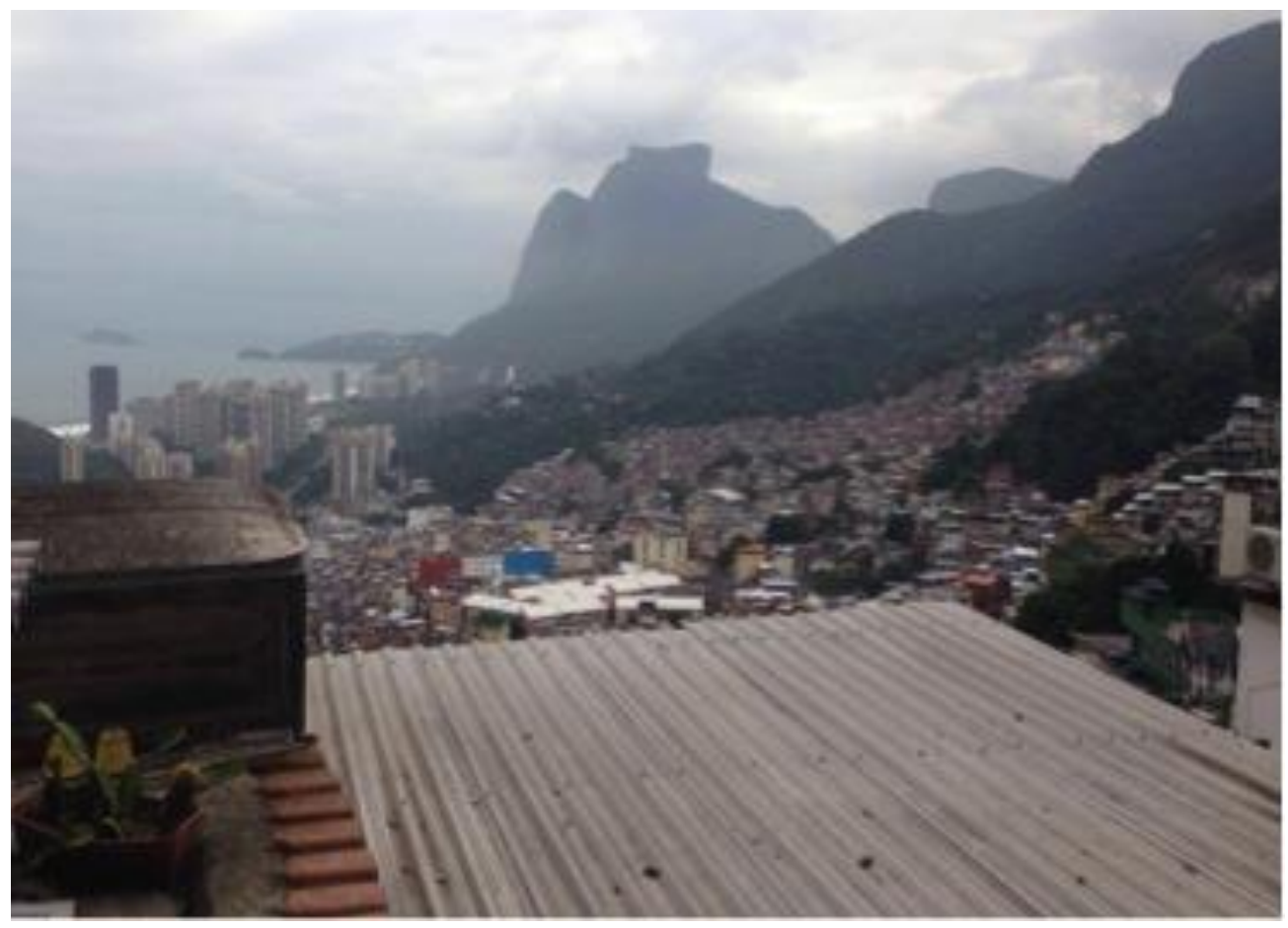

Figura 30 - Favela da Rocinha - vista da janela da cooperativa Coopa-Roca

Fonte: Foto tomada pela autora

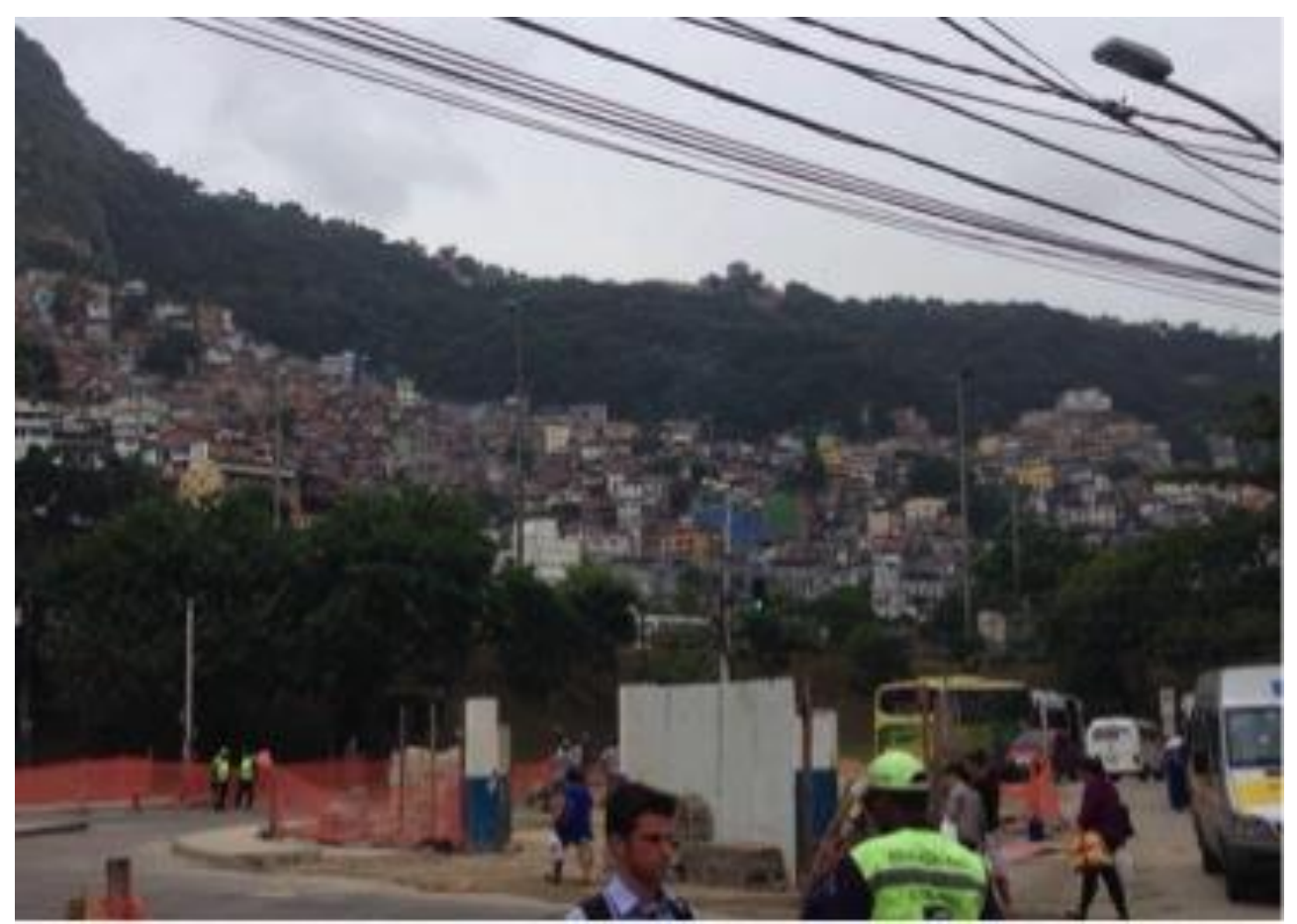

Figura 31 - Imagem da Rocinha, vista da pista de asfalto que passa em frente à favela.

Fonte: Foto tomada pela autora 
A história da Rocinha começa na década de 1920, em uma área onde havia uma antiga fazenda. Seus primeiros moradores tinham, na região, pequenas criações e plantações de verduras e legumes e, por isso, o lugar passou a ser conhecido como Rocinha (PANDOLFI; GRYNSZPAN, 2003).

A favela experimentou uma grande expansão na década de 1960, com o processo de remoção de favelas da Zona Sul da cidade e, também, com o movimento migratório da campo para a cidade. Desde essa época, destaca-se a forte origem nordestina de seus moradores (PANDOLFI; GRYNSZPAN, 2003),

Na década de 1980, a prefeitura da cidade decreta (Decreto $n^{\circ} 6.011$, de 1986) que a Rocinha e outras quatro favelas densamente povoadas passam a ser regiões administrativas, de forma a facilitar a atuação do poder público. Na década seguinte, a Lei $n^{\circ}$ 1995 (18 de junho de 1993) delimita a área correspondente a essa região administrativa da Rocinha e transforma a favela em bairro. No entanto, a Rocinha continua sendo reconhecida como favela. Segundo informações da ONG "O Portal", responsável pelo site oficial da favela, essa transformação foi de cunho "burocrático", pois o lugar continua apresentando "características físicas de favela".

Além de representar uma ocupação espacial do território muito peculiar, as favelas estampam outras características que as tornam diferentes do restante da cidade. Se observarmos o mapa publicado pelo IPP quanto ao Índice de Desenvolvimento Social $(\text { IDS })^{22}$ - por bairro, a Rocinha ${ }^{23}$ apresenta um IDS muito abaixo do restante da Zona Sul ${ }^{24}$ da cidade, onde se concentra o IDS mais alto do Rio (RIO DE JANEIRO (Prefeitura)c, 2008).

O contraste social estampado nesses locais é evidenciado, também, por estudo realizado pela Fundação Getúlio Vargas (NERI, 2011), que demonstra ser a Rocinha a região administrativa da cidade que tem a população com o menor nível de escolaridade entre todas do município do Rio de Janeiro.

Apesar disso, a Rocinha é considerada a favela campeã em empreendedorismo no Rio de Janeiro (MEIRELLES, ATHAYDE, p. 73). Para mapear esse universo, o PAC no estado do Rio de Janeiro fez um levantamento dos empreendimentos existentes na comunidade.

${ }^{22}$ IDS - O Índice de Desenvolvimento Social, calculado pelo Instituo Pereira Passos (IPP) da prefeitura do Rio de Janeiro, mede o acesso a saneamento básico; a qualidade habitacional; o grau de escolaridade e a renda da população carioca, tendo como base os resultados do Censo Demográfico do IBGE.

${ }^{23}$ IDS da Rocinha $(0,458)$.

${ }^{24}$ IDS de alguns bairros da Zona Sul, próximos à Rocinha: Lagoa $(0,854$, Leblon $(0,809)$, Ipanema $(0,801)$, Gávea $(0,787)$. 
O Censo Empresarial da Rocinha (2010) foi uma das etapas do trabalho social realizado pela equipe do PAC a fim de buscar uma aproximação com os moradores para a implantação das obras de infraestrutura e de um modelo sustentável de desenvolvimento para a comunidade. Três favelas foram estudadas: Rocinha, Complexo do Alemão e Manguinhos. Nas três, foram aplicados dois tipos de pesquisa: domiciliar e empresarial.

O levantamento identificou 6.529 empresas ou empreendedores, formais e informais. Desse total, 6.145 foram entrevistados. Entre eles, verificou-se que 90,9\% atuam na informalidade. Quando indagados sobre os motivos pelos quais não formalizavam seus negócios, 43,2\% dos empreendedores alegaram não sentir necessidade. Em seguida, eles citaram falta de capital para pagar as taxas de formalização (14\%), receio com a burocracia exigida $(9 \%)$ e falta de informação $(3,6 \%)$.

Em relação ao grau de escolaridade dos empreendedores, o documento revela que $5,2 \%$ são analfabetos e $48,2 \%$ possuem o $1^{\circ}$ grau incompleto. A baixa escolaridade, segundo depoimentos dos moradores que participaram de debates realizados pelo Trabalho Social do PAC, é uma das principais causas do elevado índice de desemprego e da precarização do trabalho na comunidade. Diante dessa realidade, o empreendedorismo passa a ser uma opção de renda para quem tem baixa escolaridade.

De acordo com o Plano de Desenvolvimento Sustentável da Rocinha, elaborado pelo PAC, em 2010, o nível de desemprego da comunidade seria de 10,7\%. Esse valor corresponde ao dobro do índice de desemprego da capital e, também, é maior do que a taxa do país em maio daquele ano (7,5\%). O documento destaca, ainda, que $44 \%$ dos trabalhadores estão em situação precária no mercado de trabalho. Nesse grupo, estariam incluídos os desempregados, assim como aqueles que se submetem a trabalhos informais, temporários ou com renda variável.

Convém ressaltar que o baixo índice de escolaridade não se restringe apenas ao universo dos empreendedores. Como foi visto no Quadro 3, a população da Rocinha destaca-se, ainda, por ter o pior índice de escolaridade entre todas as regiões administrativas da cidade.

Como uma reação em cadeia, esse baixo índice de escolaridade vem acompanhado, também, da desigualdade de renda. Enquanto, na Rocinha, a renda per capita era de $\mathrm{R} \$$ 393,00 , na cidade, a renda per capita, informada pelo Censo do IBGE 2010, era de $R \$$ 858,00 (Plano de Desenvolvimento Sustentável da Rocinha, p. 98).

Se compararmos o valor do rendimento nominal médio mensal das pessoas de 10 anos ou mais de idade, com e sem rendimento, o valor correspondente à Rocinha sobe $(\mathrm{R} \$ 488,27)$, porém continua refletindo a desigualdade em relação aos bairros próximos. $A$ 
renda no bairro da Gávea $(R \$ 3.989,76)$, vizinho, é quase 10 vezes maior, e a do Leblon $(\mathrm{R} \$ 5.088,02)$ ultrapassa essa marca (Figura 32).

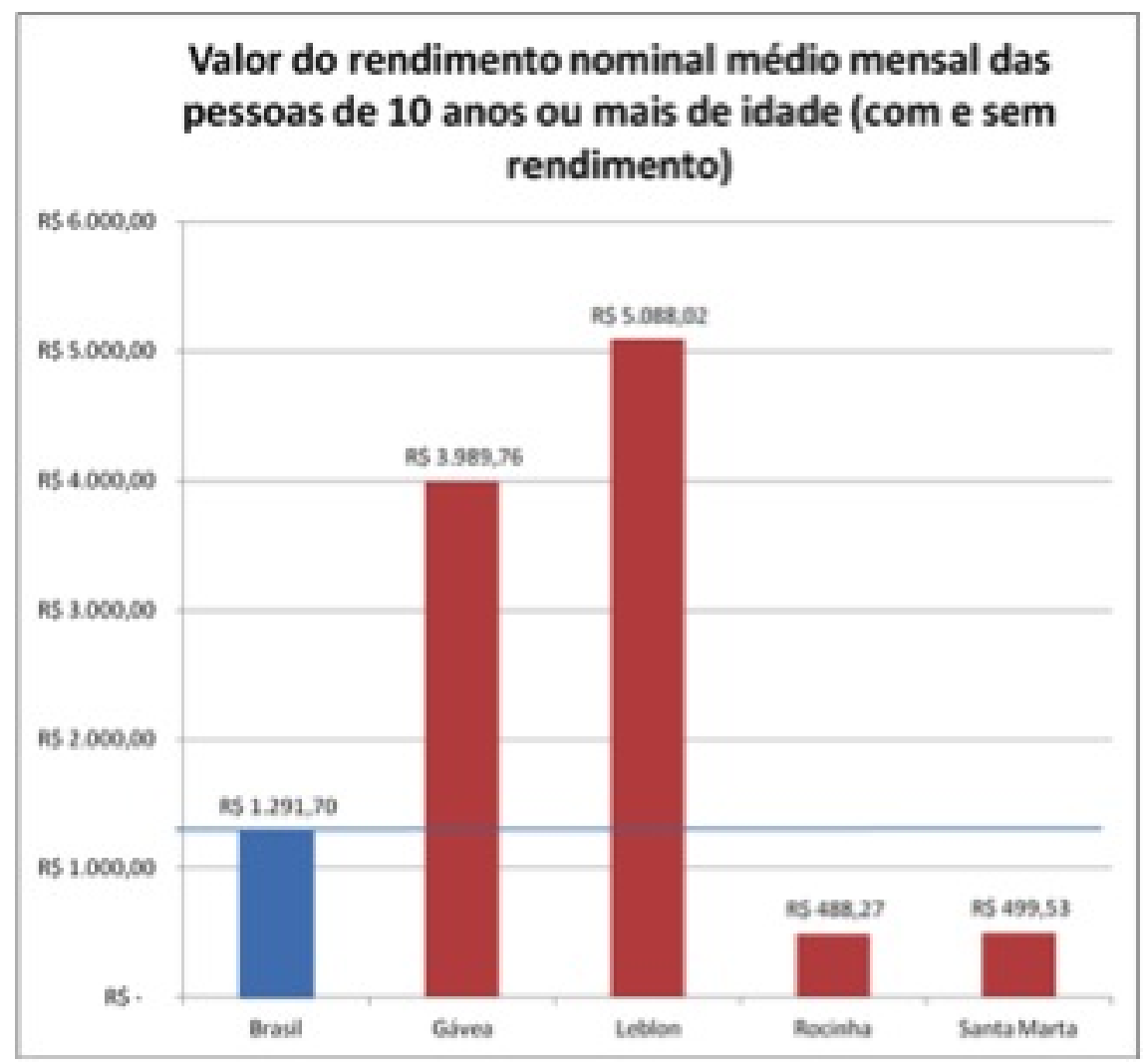

Figura 32 - Valor do rendimento nominal médio das pessoas de 10 anos ou mais de idade (com e sem rendimento). Dados: IBGE - Censo 2010

Figura elaborada pela autora

A primeira fase do PAC na Rocinha recebeu $R \$ 272$ milhões de investimentos dos governos estadual e federal. Nessa etapa, as obras concentraram-se em sua parte mais baixa. Foi construído em 2010, na pista de asfalto que passa em frente à favela, um grande complexo esportivo, ligado à comunidade por uma passarela projetada pelo arquiteto Oscar Niemeyer (Figura 33). Ao lado do local destinado ao aprendizado e à prática de diferentes modalidades de esporte, foi inaugurado uma Unidade de Pronto Atendimento (UPA) 24 horas. A Rua 4, que antes tinha 60 centímetros de largura, foi alargada e urbanizada. Foi construída, também, uma biblioteca e, ainda, foram entregues 144 unidades habitacionais. 


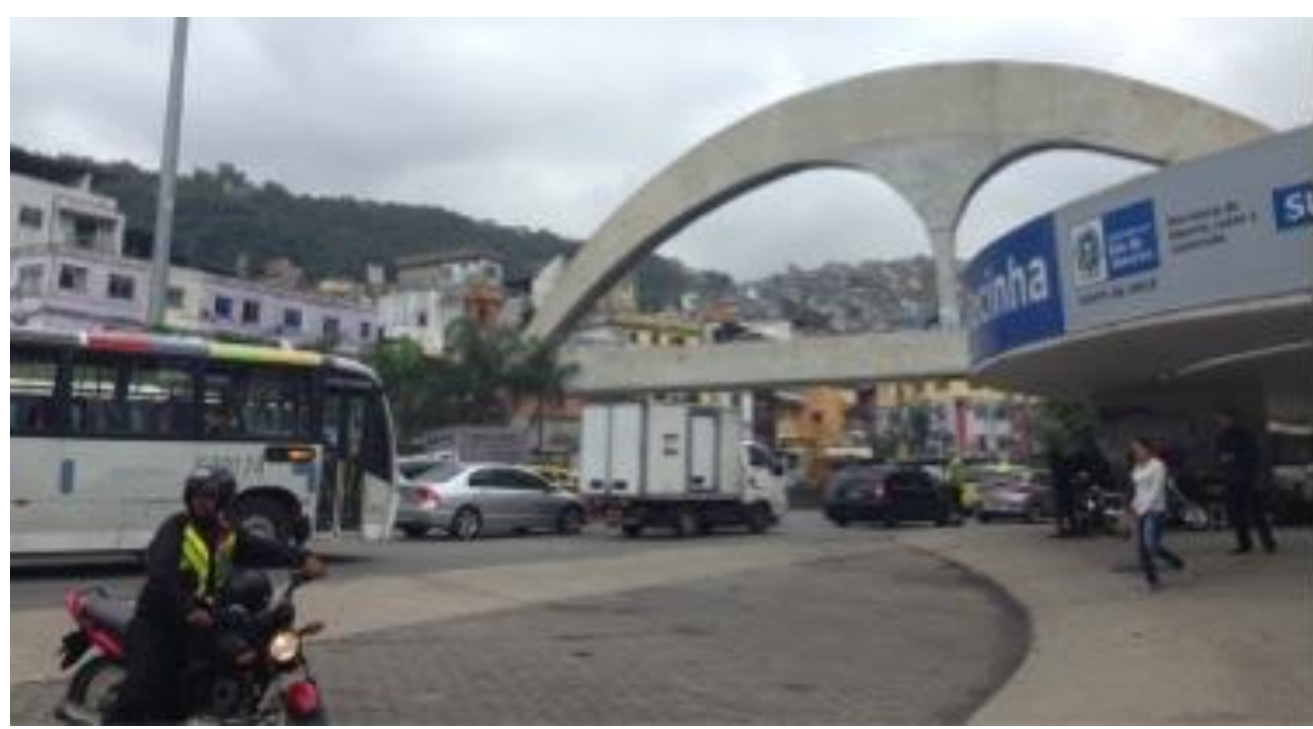

Figura 33 - Projetada pelo arquiteto Oscar Niemeyer, passarela liga o complexo esportivo à Rocinha.

Fonte: Foto tomada pela autora

Em 2015, foram aprovadas as verbas para a segunda fase do PAC nas favelas do Rio de Janeiro. Nessa etapa, foram destinados $R \$ 2,66$ bilhões para obras que melhorassem a infraestrutura das favelas da Rocinha, Lins de Vasconcelos e Jacarezinho, Desse total, o estado entraria com $R \$ 800$ milhões e a União com $R \$ 1,8$ bilhão. Dentre as três favelas selecionadas para o programa, a Rocinha seria a principal contemplada, recebendo $R \$ 1,6$ bilhão do total do investimento.

Quando visitamos a favela em 2015 e 2016, a comunidade ainda debatia uma das obras previstas para essa etapa: a construção de um teleférico como o construído no Complexo do Alemão. A obra tem como objetivo ligar a comunidade às futuras estações de metrô na Gávea e em São Conrado. Na opinião do líder comunitário José Martins de Oliveira, um dos fundadores do grupo Rocinha sem Fronteiras, que se reúne uma vez por mês para discutir temas relacionados à Rocinha, muito mais importante do que "obras midiáticas" como essa seria resolver a questão do saneamento básico. Martins é fundador da Associação de Moradores e Amigos do Bairro Barcelos (AMABB), um dos sub-bairros da Rocinha, já foi administrador regional da favela e já presidiu a Ação Social Padre Anchieta (ASPA), uma ONG que desenvolve trabalhos de promoção social, cultural e educacional na comunidade.

Ruas como a do Valão, localizada na parte mais baixa da favela e uma das principais vias de acesso para a comunidade, expõem o problema de forma incontestável. O grande canal aberto que dá nome ao lugar, recebe todo o esgoto não tratado que desce do morro e o despeja na praia de São Conrado. A construção de uma rede de esgotos resolveria não apenas a insalubridade, como, também, "contribuiria para abrir alguns becos, trazendo mais 
luz e ventilação para a favela e contribuindo para acabar com doenças como a tuberculose" (Martins, novembro de 2015).

Além do PAC, a Rocinha foi uma das favelas contempladas pelo programa de segurança pública do estado do Rio de Janeiro. Em novembro de 2011, a comunidade foi ocupada pela polícia. A Operação Choque de Paz, como foi chamada a ocupação, não teve feridos e contou com a participação da Polícia Militar, Polícia Civil, Polícia Federal e Polícia Rodoviária Federal, assim como com a presença de veículos blindados da Marinha. Em 2012, é inaugurada na comunidade a UPP, a 28 ${ }^{\text {a }}$ UPP instalada em favelas no Rio de Janeiro desde 2008.

Com a UPP, "a vida está mais em paz entre aspas. O tráfico continua existindo, mas ficou menos exposto e não temos mais tiroteio frequente como antes" (depoimento anônimo, abril de 2016).

Outra percepção sentida pelos moradores foi que depois da UPP, "há uma convivência no mesmo espaço público da (Polícia) Civil, do cara que mexe com o tráfico e dos moradores. Antigamente era impossível um cara da civil circular dentro da Rocinha tranquilamente " (depoimento anônimo, abril de 2016).

Nesses quatro anos de UPP, um acontecimento na Rocinha envolvendo os policiais da UPP foi amplamente noticiado pela mídia: o desaparecimento do auxiliar de pedreiro Amarildo de Souza. Depois de uma longa investigação, revelou-se que o pedreiro, levado por policiais, foi torturado e assassinado. O fato gerou protestos dos moradores da comunidade e repercussão nacional e internacional. Como consequência, os policiais envolvidos foram julgados e condenados. O comandante da Unidade de Polícia Pacificadora (UPP) da Rocinha, major Edson Raimundo dos Santos, recebeu a maior pena: 13 anos e sete meses de reclusão.

A morte de Amarildo trouxe à tona as dificuldades de se pacificar uma favela com a dimensão da Rocinha. Apesar dos protestos de muitos moradores contra a ação policial nesse caso, houve quem quase a justificasse, pois continuava a defender a presença da UPP no morro.

"O caso do Amarildo foi uma trama midiática e diabólica para tirar o major Édson da Rocinha. Ele era um cara que tinha uma relação muito interessante com a favela e que queria fazer a integração da polícia com a comunidade. A verdade é que a família do Amarildo nunca foi santa" (depoimento anônimo, abril 2016).

Outro depoimento sobre esse mesmo assunto, também feito em off, mostra uma interpretação semelhante. "No início da instalação da UPP, o nível de aceitação (dos 
moradores da Rocinha) foi alto, mas, com a morte de Amarildo e apoio dado ao caso pela imprensa e pela esquerda, o tráfico se sentiu fortalecido" (depoimento anônimo, abril 2016).

Hoje, ouvimos relatos de que, mesmo com a UPP, a violência continua. "Tem uma lojinha na estrada da Gávea que já foi assaltada várias vezes" (depoimento anônimo, abril 2016).

Já em relação ao ambiente de negócios, uma das consequências observadas, a partir da presença da UPP na Rocinha, foi a mudança de perfil dos negócios.

\begin{abstract}
"Depois da UPP, atividades relacionadas ao comércio de comida e roupa, assim como ao divertimento, sofreram uma quebra, porque o tráfico movimenta uma economia forte dentro do morro. Diminuiu, por exemplo, a realização de bailes funks, que hoje só é possível com autorização da polícia, e, nesses eventos, vendia-se muita comida, roupa e acessórios" (José Luiz Summer, dono da Casa das Artes da Rocinha, depoimento, abril 2016).
\end{abstract}

Depois da instalação da UPP, no lugar dessas atividades, surgiram novos empreendimentos, mostrando que a economia da Rocinha possui uma forte resiliência. Com a presença ostensiva do tráfico ou com a nova presença da polícia comunitária, a Rocinha funciona 24 horas. Em nossas idas a campo, pudemos constatar a vitalidade dessa economia, que mantém, por exemplo, a maior parte do seu comércio aberta até tarde para quem chega do trabalho ter a oportunidade de fazer suas compras na própria comunidade.

Depois da UPP, foram abertos hostels e criados tours turísticos. Embora já existisse esse tipo de turismo aqui, hoje, ele está muito mais forte (José Luiz Summer, depoimento, abril 2016).

José Luiz Summer é produtor de moda e tem loja na Rocinha há 25 anos. Já teve um estabelecimento comercial, onde oferecia aulas para modelos da comunidade no alto do morro. Há seis anos é dono da Casa de Artes da Rocinha (Figura 34), que vende objetos de arte, artesanato e moda produzidos na favela. O estabelecimento fica localizado na pista de asfalto em frente à comunidade, onde a fronteira com o bairro de classe média de São Conrado é delineada pela construção do Complexo Esportivo da Rocinha e do Centro Municipal de Cidadania (Figura 35). 


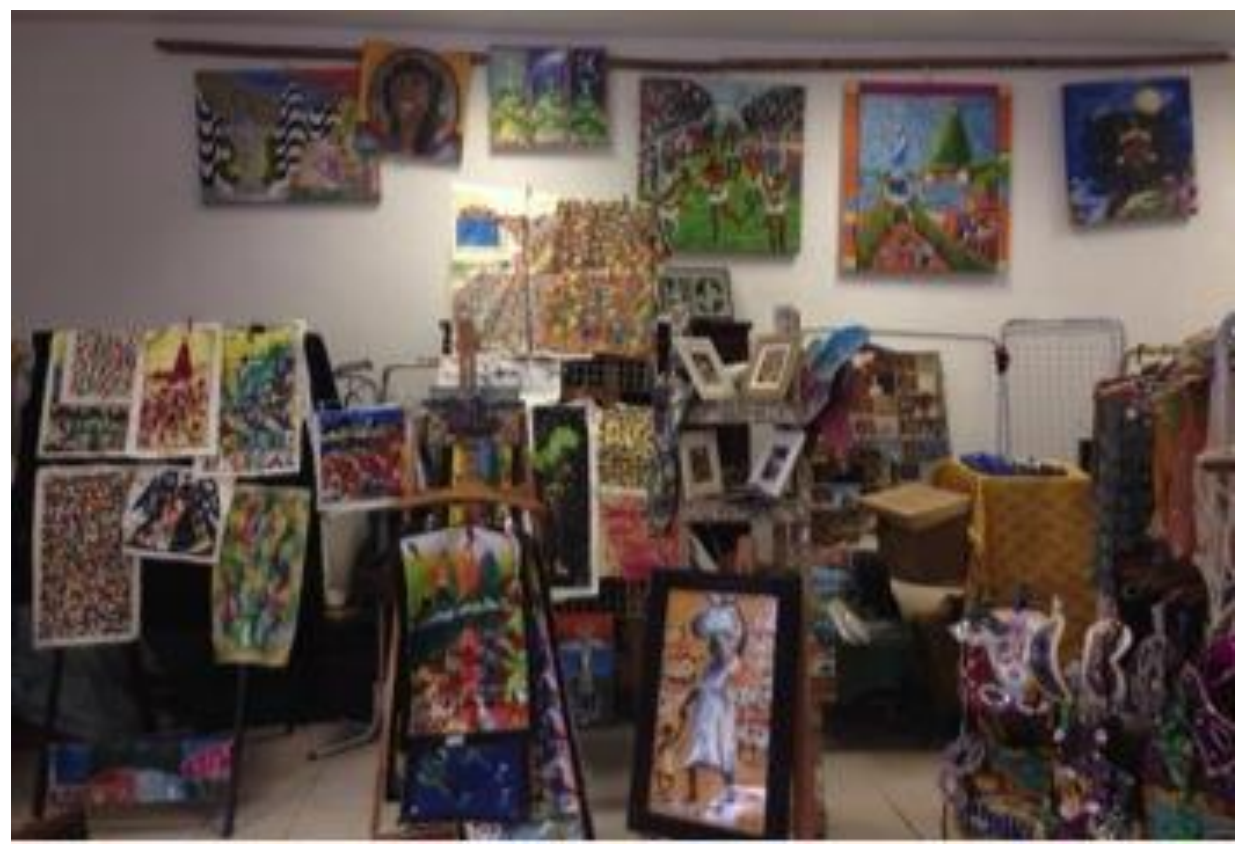

Figura 34 - Interior da Casa de Artes da Rocinha

Fonte: Foto tomada pela autora

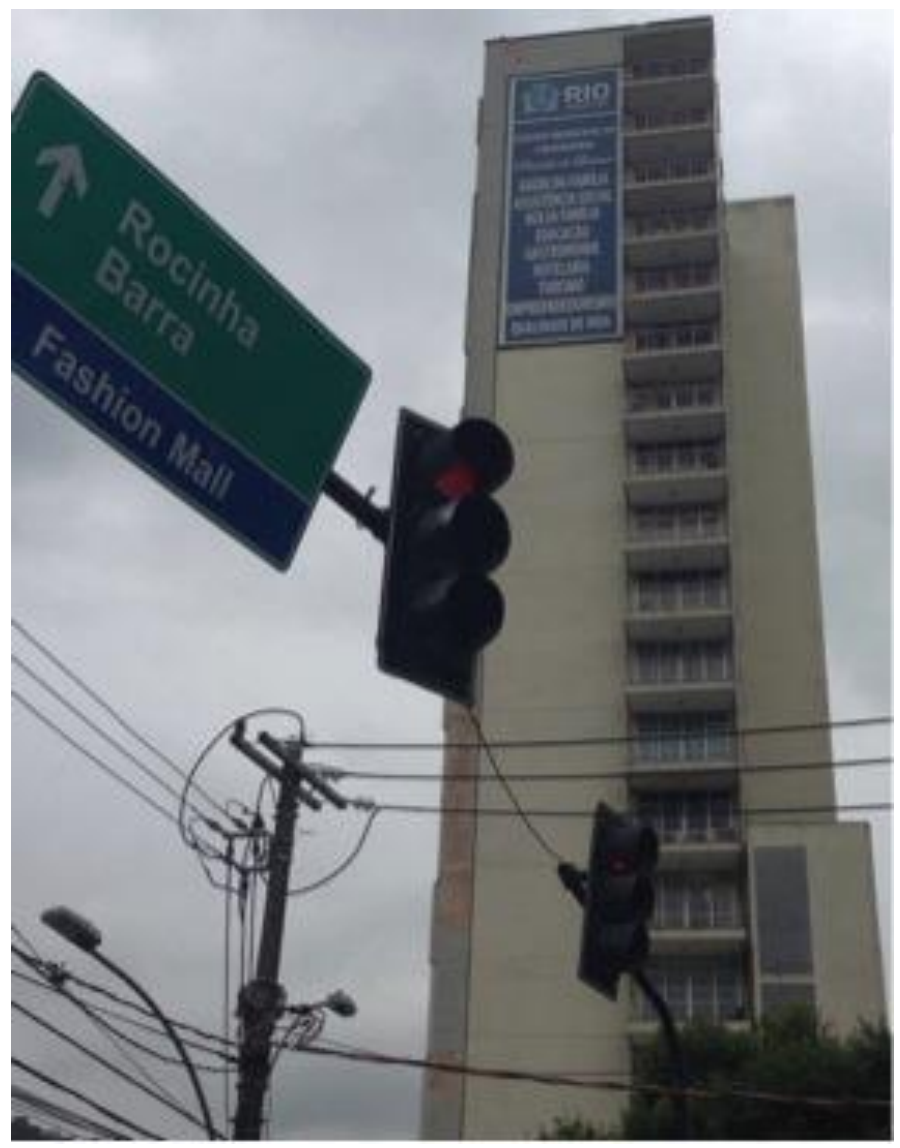

Figura 35 - Centro Municipal de Cidadania

Fonte: Foto tomada pela autora 
Ao ser indagado se percebeu algum incremento nas vendas após a instalação da UPP na Rocinha, Zé Luiz respondeu que não sentiu diferença. "Vem turista mais para conhecer a Rocinha e não de fato consumir. No verão, o movimento tem mais força. Turismo é muito por época (José Luiz Summer, depoimento, abril 2016)".

José Martins também concorda que a movimentação de turistas não interferiu tanto no comércio. "Depois da UPP, o que se pode notar de diferente é a entrada de algumas empresas na comunidade, como as que oferecem serviço de internet e telefonia (Sky, Claro, Oi), e a abertura de algumas lojas, como a de eletrodomésticos Casas Bahia e a de chocolates Cacau Show, mas isso representa pouco em termos de oferta de trabalho" (Martins, depoimento, abril de 2016).

Outros pontos destacado por Martins em relação ao empreendedorismo, após a instalação da UPP na Rocinha, foram o retorno do Sebrae para a comunidade e a abertura de uma agencia da AgeRio, Agência Estadual de Fomento. "O Sebrae sempre foi o responsável pelo incentivo ao empreendedorismo na Rocinha. Em dado momento, o pessoal teve que sair por causa da violência. Há um ano, a instituição está voltando, ainda sem uma sede" (Martins, depoimento, abril de 2016).

A AGeRio chegou na Rocinha há três anos, com o Programa de Microcrédito Produtivo Orientado. A sede da Agência está localizada no centro da cidade do Rio de Janeiro, e há um ano foi aberto um posto dentro da favela. Até o dia 15 de abril de 2016, eram oferecidos empréstimos de $R \$ 300$ a $R \$ 15$ mil, com juros de $0,25 \%$ ao mês, para quem quisesse empreender ou ampliar seus negócios. A partir dessa data, a informação que tivemos no posto da Agência na Rocinha era que devido à crise os empréstimos estavam suspensos. No site da Agência, havia a informação de que o Programa de Microcrédito Produtivo Orientado passava por uma fase de reformulação.

Diferente da favela Santa Marta, que apresentou uma grande mudança em sua economia local, trazida pelo turismo após a UPP, a Rocinha já tinha uma economia consolidada antes da política de pacificação. Não é por acaso que, assim como José Luiz Summer, Martins sublinha o fato da Rocinha funcionar 24 horas, mostrando que sua economia não depende de público externo, pois conta com um vasto mercado interno.

O comércio da Rocinha é tão dinâmico que passou a atrair, também, a presença de moradores que moram nos condomínios de classe média do bairro de São Conrado. A analista do IBGE, Isabella Nunes Pereira, é uma dessas pessoas. Desde que precisou comprar uma lâmpada, numa noite de domingo, para o apartamento recém-comprado, e a única opção próxima de casa era a Rocinha, passou a se interessar pelo dinamismo da economia do lugar.

O interesse foi tanto que se transformou em objeto de estudo. Em 2014, Pereira concluiu sua tese de doutorado sobre a atividade empreendedora do lugar, na qual buscou 
investigar de que modo os empreendedores moradores da Rocinha iniciam seus negócios. Sua percepção é que não há uma relação direta do desenvolvimento do empreendedorismo na Rocinha com a instalação da UPP. "É preciso considerar que essa associação do florescimento do empreendedorismo com a pacificação é relativa. A Rocinha sempre foi empreendedora" (Isabella Nunes Pereira, depoimento, abril de 2016).

O impacto da UPP na Rocinha, em sua opinião, foi mediático e simbólico. Ela lembra que a UPP chegou na Rocinha, em 2012, de forma apoteótica e com grande aceitação da população da favela. No entanto, logo depois vieram as limitações. "A cultura passou a sofrer controle. O baile funk, por exemplo, passou a ser considerado música de bandidos. Com o episódio do Amarildo, a UPP perdeu a credibilidade. A população percebeu que convivia com a polícia sob o domínio da força, sem o respeito" (Pereira, depoimento, abril 2016).

Quando indagada se reconhece ter havido um aumento no empreendedorismo na favela nos últimos anos, Pereira (2016) diz que "o aumento do empreendedorismo na região está associado ao mercado interno e ao crescimento de sua população. De acordo com o IBGE, a Rocinha é a favela carioca que mais cresce. Seu crescimento de $23 \%$ é quase o triplo da média do munícipio, que é de 7,9\%, e, também, superior ao crescimento das grandes favelas da zona norte da cidade, como o Complexo da Maré (14\%) e do Alemão (6,3\%)" (Pereira, depoimento, abril 2016

Dessa forma, Pereira (2016) não atribui a abertura de novos estabelecimentos comerciais na comunidade, como Subway, Mundo Verde, restaurante japonês e salão de beleza, à pacificação, mas simplesmente à busca por mercado. Esse mercado é constituído por "uma população que teve acesso à melhoria de renda e mudou hábitos de consumo" (Pereira, depoimento, abril 2016).

Assim como José Martins e José Luiz, Pereira, também, ressalta a vitalidade da economia da Rocinha quando procura caracterizar o empreendedorismo dessa favela. "A Rocinha é um mercado enorme. É um mini mundo. Uma cidade dentro da cidade. Isso já é antigo. A organização comercial sobrevivia às leis do tráfico" (Pereira, depoimento, abril 2016).

Outra peculiaridade que contribui para o desenvolvimento do empreendedorismo da Rocinha, observada por Pereira, é a oportunidade que a maior parte dos empreendedores tem de se qualificar na prática profissional, antes de abrir seu próprio negócio. "A Rocinha tem muita gente que trabalha no setor de serviços diretamente com os donos dos estabelecimentos, como garçons, cozinheiras, manicures, cabelereiras etc. Nesses locais, na relação direta estabelecida com seus patrões, os trabalhadores acabam se qualificando para um dia abrirem seus próprios negócios" (Isabella Nunes Pereira, depoimento, abril 2016). 
Por meio dessas relações, Pereira (2014) mostra, em sua pesquisa, que é criada uma rede vertical de contatos na qual a Rocinha é conectada com o ambiente externo à favela. Além da rede vertical, há, ainda, uma intrincada rede interna de relações formada pela família e amigos que oferece o suporte e apoio necessários para a viabilização dos empreendimentos. A pesquisadora lembra que "os primeiros empreendimentos da Rocinha surgiram em torno do fornecimento de quentinhas (refeições) para os próprios moradores da favela que trabalhavam na construção civil" (Isabella Nunes Pereira, depoimento, abril 2016).

Conhecida como uma cidade dentro da cidade e caracterizada, ainda, como a favela campeã em empreendedorismo (MEIRELLES; ATHAYDE, p.73), a Rocinha parece não ter se beneficiado tanto com a política de pacificação nesses três anos de UPP. Muito antes da instalação da UPP na favela, em 2012, o empreendedorismo já era uma atividade econômica consolidada entre seus moradores.

\subsubsection{COOPA-ROCA}

A Coopa-Roca, Cooperativa de Trabalho Artesanal e de Costura da Rocinha Ltda., é um dos grupos de mulheres artesãs, moradoras de favela, mais antigos do Rio de Janeiro em funcionamento até hoje. Existe desde o início da década de 1980.

Atualmente, a cooperativa passa por uma reformulação, com a saída de Maria Teresa Leal, ex-coordenadora do grupo. Maria Teresa, ou Tetê, como é conhecida pelas cooperativadas, embora não tenha nascido na Rocinha, nem nunca tenha morado lá, ajudou a criar a Coopa-Roca.

Socióloga, Maria Teresa morava no Leblon, bairro de classe média alta da Zona Sul, quando resolveu iniciar, no começo da década de 1980, uma oficina de reciclagem de materiais para crianças na Rocinha. Um dia, ela conseguiu uma doação de retalhos e surpreendeu-se com a habilidade manual das moradoras, migrantes nordestinas.

Ao perceber que as migrantes nordestinas haviam trazido consigo o domínio de técnicas artesanais, vi naquilo uma ótima oportunidade para unir interesse e capacidades (LEAL, M. T., 2006).

O selo social da Coopa-Roca e o padrão de qualidade das peças fizeram o grupo, rapidamente, conquistar prestígio nacional e internacional. No Brasil, a cooperativa já vendeu para marcas famosas como Osklen, M. Officer e Lenny. No exterior, suas peças confeccionadas com bordados, crochês, e outras técnicas artesanais tradicionais (Figura 36) já foram exibidas nas passarelas das grandes capitais da moda, como Berlim, Londres, Paris e Nova lorque. 


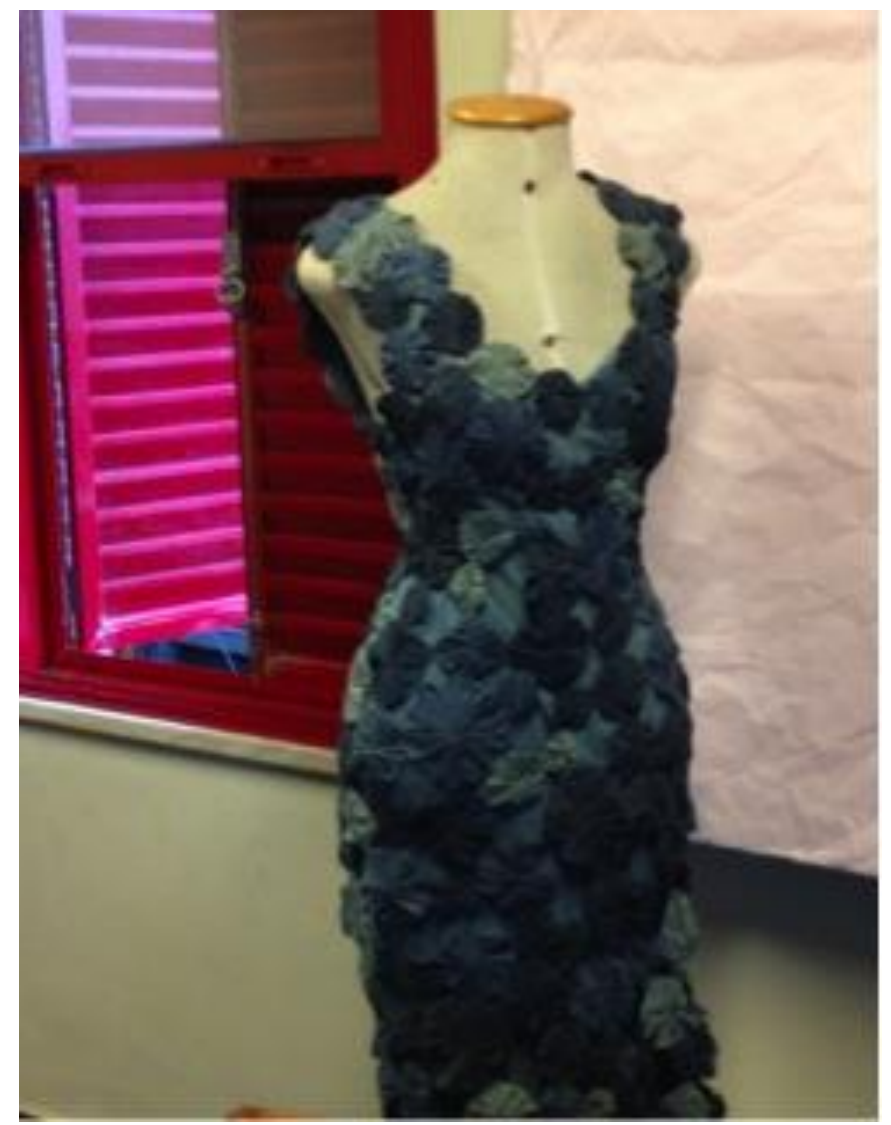

Figura 36 - Vestido de fuxico feito pelas costureiras da Coopa-Roca

Fonte: Foto tomada pela autora

Atualmente, o grupo funciona na sede de três andares da Rua Um, na parte mais alta da favela, onde o morro, logo em seguida, começa a descer para a Gávea. A casa foi adquirida, por meio de financiamento, um ano após a criação da cooperativa.

Nas prateleiras das estantes, é possível conferir alguns dos produtos feitos pelas artesãs. Colares, vestidos de crochê, bolsas e almofadas de linho bordadas (Figuras 37 e 38). Toda a produção demonstra um alto controle de qualidade no acabamento e muito bom gosto na escolha do material, das cores e dos modelos. No início de 2015 , essa produção estava à procura de comprador. 


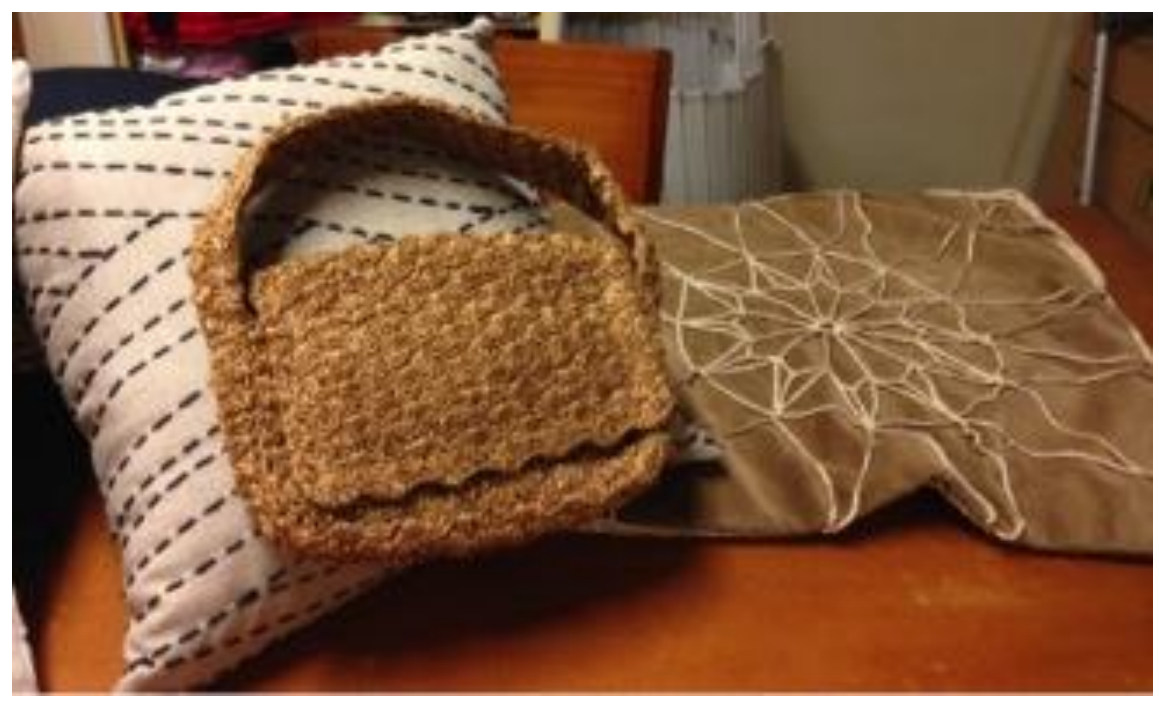

Figura 37 - Almofadas de linho bordadas e bolsa de crochê da Coopa-Roca.

Fonte: Foto tomada pela autora

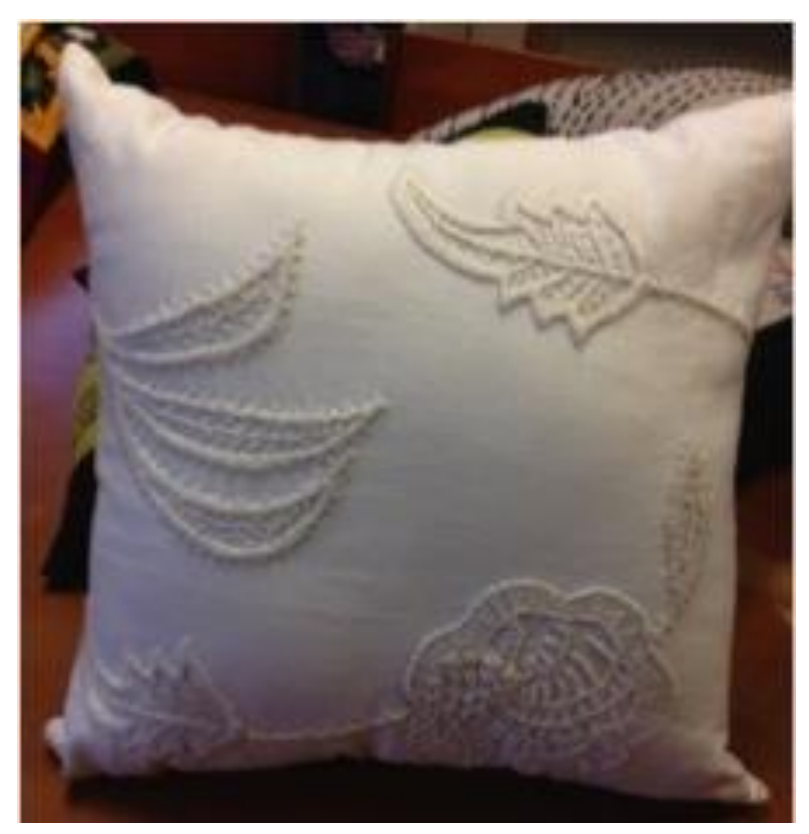

Figura 19 - Almofada bordada em linho produzida pela Coopa-Roca.

Fonte: Foto tomada pela autora

O escoamento da produção foi uma das maiores dificuldades apontadas pelas artesãs. "Tudo que é feito à mão demora mais tempo para ser produzido, por isso fica mais caro. E o mercado não quer pagar" (Lucélia Carvalho, depoimento, abril de 2015).

Por esse motivo, a atividade artesanal, que já foi exercida como a principal fonte de renda dessas mulheres, hoje, é considerada atividade complementar. 
Quando tinha trabalho o ano todo, já chegou a ser a nossa principal atividade. Mas isso foi quando trabalhávamos com parceiros, agora não trabalhamos mais (Lucélia Carvalho, depoimento, abril de 2015).

A parceria a que a artesã se refere significa uma parceria comercial para quem as artesãs produziam por encomenda.

A cooperativa já teve dois pontos comerciais para comercialização da produção, o primeiro, no shopping Rio Sul, na Zona Sul da cidade, e o outro, no shopping Fashion Mall, no bairro de São Conrado, vizinho à Rocinha. No primeiro, aberto em 1995, Dona Luci Carvalho, artesã que já trabalha há 19 anos na cooperativa e mãe de Lucélia, diz que o grupo ainda não havia registrado a marca. O quiosque durou cerca de um ano.

Depois de doze meses, percebi que não estávamos prontas para comercializar nossos produtos diretamente. Não tínhamos infraestrutura para isso. A experiência, contudo, foi muito positiva. Ela serviu de ponte para o entendimento de uma estratégia de negócios que pudesse ampliar a escala de produção e aumentar o número de mulheres envolvidas (LEAL, M. T., 2006).

A loja do Fashion Mall foi aberta, em 2012, com o apoio do Sebrae, da prefeitura e do Serviço Nacional de Aprendizagem do Cooperativismo (SESCOOP). Nessa época, o grupo já havia registrado a marca. Mas essa segunda experiência não durou muito mais do que a primeira.

O shopping Fashion Mall cedeu o espaço e nós não precisávamos pagar nada. Tivemos a loja durante um ano e pouco, mas o shopping pediu o espaço de volta para fazer uma área de lazer (Lucélia Carvalho, depoimento, abril de 2015).

Maria Áurea, uma das três diretoras do grupo atualmente (Figura 39), diz que a loja fechou, também, por má gestão. Prova disso é a dívida acumulada. "Estamos assumindo a cooperativa com uma dívida de mais de meio milhão de reais" (Maria Áurea, depoimento, abril de 2015). 


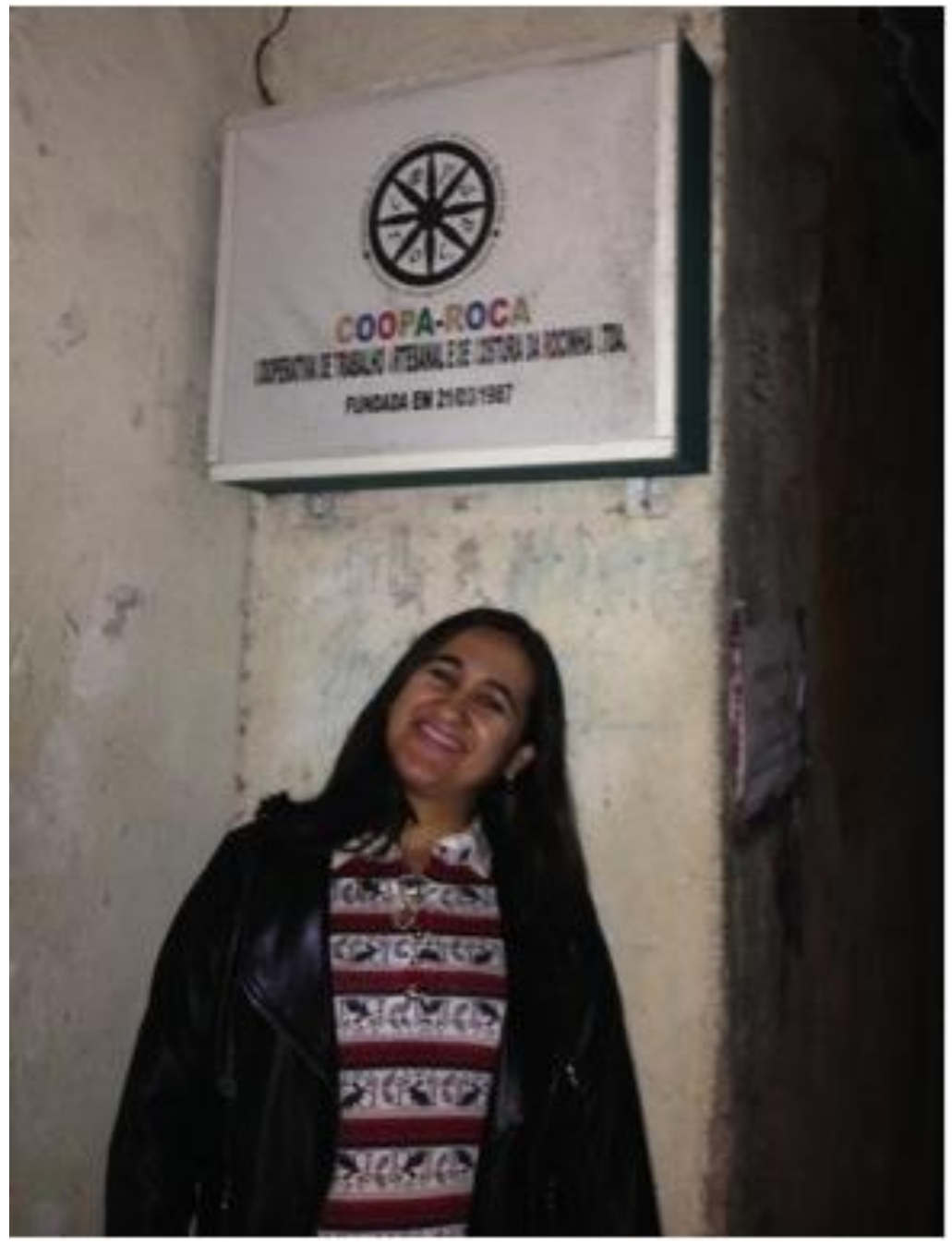

Figura 20 - Maria Áurea, uma das diretoras da Coopa-Roca.

Fonte: Foto tomada pela autora

A situação difícil pela qual a cooperativa passou nos últimos anos reflete no encolhimento do grupo. "O grupo já chegou a ter mais de 100 mulheres; hoje, reúne apenas 19". (Lucélia Carvalho, depoimento, abril de 2015).

A maioria tem suas raízes no Nordeste. Maria Áurea, por exemplo, veio do Ceará, onde aprendeu com a mãe a arte do bordado e do crochê (Figuras 40 e 41).

Minha primeira agulha de crochê fui eu mesma quem fiz, aos 11 anos de idade, com um pedaço de madeira. Não aguentei esperar a feira, que era uma vez na semana (Maria Áurea, depoimento, abril de 2015). 


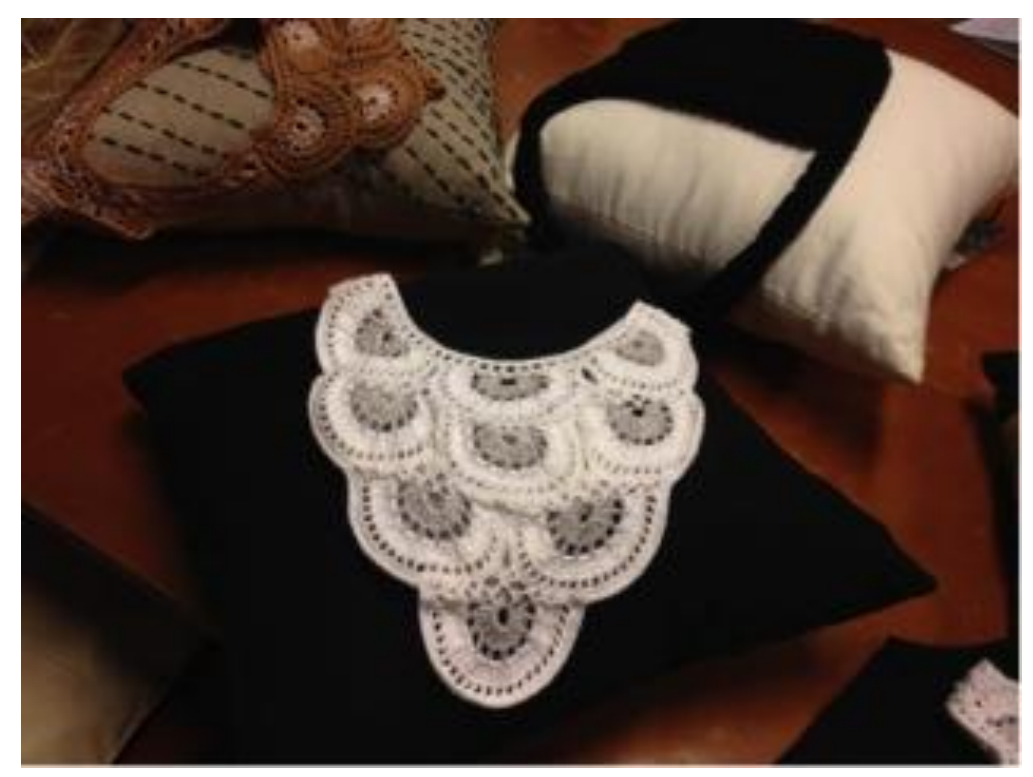

Figura 40 - Bordados para aplique em roupa. Ao fundo, bolsa em crochê preta.

Fonte: Foto tomada pela autora

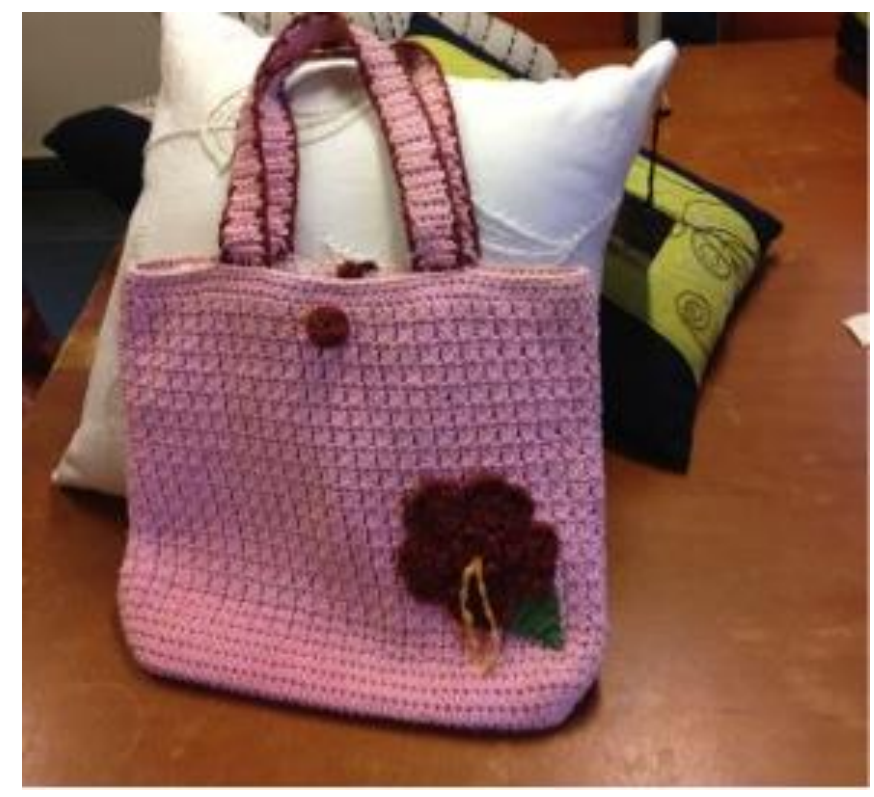

Figura 41 - Bolsa em crochê e almofadas em linho bordadas.

Fonte: Foto tomada pela autora

Sua entrada no grupo não foi por acaso. Uma prima que tinha morado na Rocinha havia the falado da cooperativa antes mesmo de Maria Áurea se mudar para o Rio de Janeiro. Quando chegou à cidade, foi trabalhar para a patroa de uma irmã que tinha acabado de dar à luz.

Depois do expediente, eu me sentava na porta de casa para fazer crochê. Um dia, Dona Isabel, artesã do grupo, me convidou para conhecer o trabalho da cooperativa (Maria Áurea, depoimento, abril de 2015). 
Em 2016, Maria Áurea da Paz completa 14 anos de participação na Coopa-Roca. Como uma de suas atuais diretoras, ela vivencia um grande desafio. Além da dívida de meio milhão de reais herdada, que impede a obtenção de financiamento para a produção, o grupo enfrenta, ainda, uma briga judicial para conseguir manter a marca.

Diante de todos os problemas, entretanto, Maria Áurea continua acreditando no potencial da cooperativa, que já chegou a vender suas peças no mercado internacional, como a luminária de crochê desenhada pelo designer holandês Tord Boontje. Hoje, Maria Áurea e suas companheiras de trabalho tentam refazer os contatos para comercializar o que está nas prateleiras e firmar novas encomendas.

A exportação é uma das vantagens apontadas pelo grupo em se organizar na forma de cooperativa.

Embora a cooperativa pague $19 \%$ de ICMS na comercialização dos produtos, se exportar, não paga impostos sobre exportação (Maria Áurea, depoimento, abril de 2015).

Quando cruzávamos por dentro a Rocinha, de sua parte mais alta até o asfalto, descendo escada, becos e ruelas, ouvimos, já sem o gravador ligado, o que consideramos o ponto alto de nossa entrevista. O desabafo de que, embora a cooperativa vendesse a imagem de uma participação igualitária de seus membros, a gestão anterior não havia sido democrática.

As cooperativadas contaram que muitos dos contatos da carteira de clientes, por exemplo, foram firmados por Tetê, sem elas terem acesso a eles. Lembraram, ainda, da experiência constrangedora de uma viagem ao exterior para uma exposição em que não conseguiram se comunicar em língua estrangeira.

No início de nossa pesquisa, sem sabermos que o grupo estava passando por uma crise de gestão, tentamos entrar em contato com Maria Teresa Leal, mas não conseguimos seu depoimento. Chegamos à cooperativa, telefonando para José Martins de Oliveira, líder comunitário muito conhecido e respeitado na Rocinha.

Em relação aos possíveis benefícios trazidos pela pacificação, iniciada na Rocinha no final de 2011, Luci Carvalho faz um momento de silêncio. Quando a pergunta é reformulada para os efeitos da pacificação nas vendas do grupo, ela responde que não sentiu diferença. "Em relação ao trabalho da cooperativa, não mudou nada" (Luci Carvalho, depoimento, janeiro de 2016).

Entretanto, sua filha Lucélia Carvalho, lembra que "quando havia 'confronto' não tínhamos condições de chegar na parte alta para trabalhar. Nesse aspecto, agora melhorou" (Lucélia Carvalho, depoimento, abril 2016). 
Sua mãe, Luci Carvalho, quando indagada, por exemplo, se a melhoria em relação ao acesso de pessoas de fora do morro para a Rocinha teria alterado o resultado das vendas dos produtos Coopa-Roca, sua percepção é que não houve alteração. "Nossos produtos, por serem mais caros, não são vendidos dentro da comunidade" (Luci Carvalho, depoimento, janeiro de 2016).

Quando a situação da Santa Marta é citada para ilustrar a mudança positiva na comunidade, Luci sorri e diz: "São comunidades muito diferentes. Você já viu o tamanho da Rocinha?" (Dona Luci, depoimento, janeiro de 2016).

O silêncio inicial e as respostas de Dona Luci passam a impressão de que falar de resultados da pacificação de um território tão complexo como o da Rocinha é ainda prematuro.

$\mathrm{Na}$ segunda vez que voltamos à Rocinha para uma visita informal a outro grupo de mulheres artesãs e, em seguida, ir a uma festa de aniversário celebrada em uma laje, nos deparamos com um grupo de adolescentes armados de fuzis. Um pouco mais adiante, turistas estrangeiros passavam sorridentes, conversando alheios àquela outra realidade.

Quando relatei o fato à Dona Luci, ela perguntou: "Mas onde foi isso? Aqui perto da minha casa, isso não acontece." (Dona, Luci, depoimento, janeiro de 2016).

O depoimento de outro morador, realizado em off, explica essa realidade. "Hoje diminuiu a exposição de pessoas armadas nas ruas principais, como a Via Ápia e a Estrada da Gávea, mas nos becos ela continua" (depoimento anônimo, abril 2016).

Um segundo morador, que, também, pediu para não ser identificado, reforça a percepção de que a pacificação é um processo na Rocinha que está longe de ser consolidado. "A paz é nova e não é perfeita. É um processo e está, no nosso caso, em decadência. A UPP foi inaugurada aqui na comunidade com 700 homens e, hoje, deve ter apenas 100" (depoimento anônimo, abril 2016).

Diante dessas falas, entendemos que a territorialização da violência continua na Rocinha. E se o domínio do tráfico não é exposto em todos os lugares da favela, quem vive e trabalha lá sabe que ele continua fazendo parte do cotidiano da comunidade. 


\section{CONCLUSÃO}

$\mathrm{Na}$ presente pesquisa, buscamos analisar a relação da pacificação das favelas na cidade do Rio de Janeiro com o desenvolvimento do empreendedorismo nessas comunidades, especialmente aquele relacionado à produção artesanal realizada por mulheres. Propomos, ainda, investigar a importância da atividade artesanal nessas áreas de notória vulnerabilidade social como alternativa econômica.

Para a realização do estudo, procuramos entender, inicialmente, em que contexto se deu a instituição da nova política de segurança pública no Rio de Janeiro, o que se esperava dela ao ser criada e como vem se dando a sua implementação.

Verificamos que a atual política de segurança pública no Rio de Janeiro, representada pela instalação de UPPS em favelas, vem ocorrendo em um contexto de revitalização do município do Rio de Janeiro. No entanto, junto a esse movimento, continuam coexistindo duas realidades contrastantes, marcadas pela desigualdade social. As favelas, embora não sejam o único reduto de pobreza, são ícones desse contraste. Pelas características geográficas da cidade, elas estão incrustradas em várias regiões, muitas vezes lado a lado com bairros prósperos, não deixando dúvida da existência de uma estigmatização territorial da pobreza urbana.

Depois de estudarmos algumas abordagens da pobreza urbana, verificamos como se consolidou a criminalização das favelas, a partir da exacerbação da violência, causada pela entrada do Rio de Janeiro na rota internacional do tráfico de drogas a partir do início dos anos 1980. Ao transformar as favelas em seus quartéis-generais, o tráfico, principalmente da cocaína, impôs um poder paralelo que dominou esses territórios e contribuiu para aumentar a cisão entre eles e o restante da cidade.

Concluímos que a atual política de pacificação, cujo objetivo é a reconquista pelo Estado desses territórios, dominados pelo tráfico e pelas milícias, é um processo ainda não consolidado mesmo nas favelas em que foi implementado. Assim, a expectativa de que o retorno da segurança e da paz a essas áreas consiga garantir o exercício de outros direitos e pavimente uma via possível para maior integração favela/asfalto, por enquanto, continua sendo uma aposta.

Diante do desafio de mudar a realidade marcada durante tanto tempo pelo terror das armas de fogo e pelo desmando das leis, o Estado tem buscado com a pacificação estimular o desenvolvimento socioeconômico desses locais. Nesse contexto, tem investido em educação, saúde e geração de renda nas áreas pacificadas. 
Alguns resultados têm demonstrado que as UPPs, desde sua criação, vêm sendo acompanhadas de algumas importantes melhorias sociais como a ampliação do Programa Saúde da Família, a criação de novos Espaços de Desenvolvimento Infantil (EDI) e a abertura de 9 mil vagas nas escolas das comunidades pacificadas. $O$ fato de o rendimento escolar dos alunos nessas áreas ter sido maior do que o observado no município como um todo, entre 2009 e 2013, pode ser um indicativo positivo dessa mudança em curso.

Em relação ao empreendedorismo nas favelas, embora não seja possível aferir em que medida a pacificação tem conseguido beneficiá-lo, vimos, a partir de levantamento de dados secundários que os efeitos dessa política têm sido reconhecidos por quem possui negócios na favela. O impacto das UPPs sobre a segurança foi o fator positivo mais ressaltado entre esses microempreendedores.

Além de promover um ambiente mais seguro para o funcionamento dos empreendimentos, a pacificação tem sido valorizada, também, por quem de alguma forma aposta nesse tipo de atividade econômica como oportunidade para o desenvolvimento dessas áreas. Ela tem atraído a atenção de formuladores de política, empresários e instituições como Sebrae e Firjan para ações que visam fortalecer o setor.

O Sebrae, por exemplo, que trabalha com incentivo ao empreendedorismo em diversas cidades brasileiras, tem conseguido ampliar sua atuação nesses territórios depois da implantação da nova política de segurança pública. A pacificação tem permitido que a entidade organize oficinas de capacitação para o desenvolvimento de novos produtos, assim como para a melhoria da qualidade da produção e formalização dos negócios.

Em nossas pesquisas de campo, tanto na Santa Marta e na Rocinha, onde concentramos nossos estudos, como em visitas a outras comunidades que, também, receberam as UPPs, podemos perceber, entretanto, que os efeitos dessa política no ambiente dos negócios não são homogêneos.

Em comunidades menores, e onde o processo de pacificação foi iniciado há mais tempo, esses efeitos foram sentidos e ressaltados como positivos. Tanto na Santa Marta, como na Babilônia, as mulheres artesãs destacaram que a pacificação trouxe, sim, benefícios, tanto para a vida delas como para os negócios. Viver mais tranquilamente sem a ameaça de saber que um filho está passando no meio de um tiroteio, experimentar o direito de ir e vir, ter maior reconhecimento e visibilidade para seus trabalhos e poder vender dentro das favelas para turistas são algumas das vantagens citadas, trazidas pela pacificação.

No caso de favelas maiores, e onde o processo de pacificação é mais recente, como é o caso da Rocinha, a presença das UPPs parece não ter promovido grandes alterações, nem para os negócios, nem para a vida das pessoas. Ainda assim, foi percebida a 
ampliação dos investimentos públicos e privados e a diminuição da presença ostensiva do tráfico. Reconhecemos, entretanto, a necessidade de que novas pesquisas sejam desenvolvidas, buscando dar continuidade à investigação dos efeitos positivos da pacificação mesmo nas favelas onde essa política apresenta-se mais consolidada.

Em relação à análise sobre a importância social da atividade artesanal, podemos concluir que diversos acontecimentos recentes têm mostrado o reconhecimento da atividade econômica como instrumento capaz de contribuir para a inclusão social e consequentemente melhorar a integração das favelas com a cidade. Um bom indicador do valor do artesanato pode ser aferido por sua grande representatividade entre o total de empreendedores registrados no Cadastro Nacional de Empreendimentos Solidários (17\%).

A recente consolidação de políticas públicas, como a institucionalização da política de economia solidária no município do Rio de Janeiro (Lei $n^{-} 5.435$, de 12 de junho de 2012) é um marco importante nesse sentido. A aprovação da lei do artesão (Lei $n^{\circ}$ 13.180), no final de 2015, regulamentando a profissão e colocando o artesão como objeto de política específica no âmbito da União representa, também, um avanço na mesma direção.

A realização de feiras e eventos em vários pontos da cidade para a comercialização de produtos artesanais, alguns deles já incluídos no calendário oficial da cidade, reforça a importância que a atividade econômica vem assumindo. O produto artesanal feito nas favelas conquista relevância não só na cidade como, por meio do comércio eletrônico e exposição em feiras nacionais e internacionais, rompe fronteiras e alcança outros locais.

Outra conclusão a que chegamos é que a atividade artesanal tem demonstrado ser uma oportunidade de geração de trabalho e renda especialmente importante no caso das mulheres em situação de vulnerabilidade social, servindo para reduzir as desigualdades existentes entre gêneros no mercado de trabalho. Nossas pesquisas de campo mostraram, ainda, a valorização por parte das mulheres da possibilidade que a atividade oferece de conciliarem o trabalho e o cuidado com a família. 


\section{REFERÊNCIAS}

ABRAMOVAY, Ricardo. O capital social dos territórios: repensando o desenvolvimento rural. Revista Economia Aplicada - n. 2, vol. IV: 379-397, abril/junho 2000.

ALBAGLI, Sarita; MACIEL, Maria Lúcia. Capital social e empreendedorismo local. Rede de Pesquisa em Sistemas Produtivos e Inovativos Locais. Set. 2002. Disponível em: <http://www.ie.ufrj.br/redesist>. Acesso em: 18 jun. 2013. p. 1-28.

ALBERNAZ, E; CARUSO, H; PATRÍCIO, L. Tensões e desafios de um policiamento comunitário em favelas do Rio de Janeiro: o caso do Grupamento de Policiamento em Áreas Especiais. São Paulo em Perspectiva v.21, n.2, p.39-52, jul./dez. 2007.

ALCOFORADO, Guilherme Sawatani Guedes; CHACON, Suely Salgueiro. O homo situs e suas interações com o desenvolvimento sustentável. IV Encontro Universitário da UFC no Cariri, 17 a 19 de dezembro de 2012, Universidade Federal do Ceará - Juazeiro do Norte CE.

ALQUÉRES, J. L, A evolução do ambiente de negócios no Rio de Janeiro. In: URANI, A.; GIAMBIAGI, F..(Orgs.) Rio: a hora da virada. Rio de Janeiro: Elsevier, 2011, p. 60-72.

ALVES, Hayda; ESCOREL, Sarah. Massa marginal na América Latina: 99 mudanças na conceituação e enfrentamento da pobreza 40 anos após uma teoria. Physis Revista de Saúde Coletiva, Rio de Janeiro, 22 [ 1 ]: 99-115, 2012.

ALVES, M. H. M.; Evanson, P. Vivendo no fogo cruzado: moradores de favela, traficantes de droga e violência policial no Rio de Janeiro. Tradução Fernando Moura. 1. ed. São Paulo: Unesp, 2013. Tradução de: Living in the Crossfire.

ALVITO, Marcos; ZALUAR, Alba (Orgs.). Um século de favela. Rio de Janeiro: FGV, 2006. $372 \mathrm{p}$.

AMARAL, Luiz. Técnicas de jornal e periódico. Rio de Janeiro: Tempo Brasileiro, 1987.

ASTI, A. O Gargalo da Comercialização na Economia Solidária. Revista Rio Ecosol: Economia Solidária, Comércio Justo e Desenvolvimento Local. Rio de Janeiro, p. 18-23, dez. 2012. 
BANCO MUNDIAL. O retorno do Estado às favelas do Rio de Janeiro: uma análise da transformação do dia a dia das comunidades após o processo de pacificação das UPPs. $2013^{\mathrm{a}}$.

BANCO MUNDIAL. Pobreza e Prosperidade. Relatório Anual $2013^{\mathrm{b}}$

BATISTA; Valente. Risco de retrocesso. O Globo, 22/11/2015, p. 33.

BECK, Ulrich. Sociedade de risco: rumo a uma outra modernidade. São Paulo: 34, 2010.

BERGAMO, M., Conheça melhor o novo perfil da Rocinha pós-pacificação. Disponível em: <http://www.rocinha.org/noticias/rocinha/view.asp?id=2800>, Acesso em: 20 dez. 2015.

BOURDIEU, P. The forms of capital. In: J. Richardson (Ed.) Handbook of Theory Research for the Sociology of Education (New York, Greenwood), 1986, p.241-258

BRASIL Ministério do Trabalho e Emprego. O que é Economia Solidária. Disponível em www.mte.gov.br/ecosolidaria/o-que-economia-solidária.htm. Acessado em 10/10/2015.

BRASIL Ministério das Relações Exteriores. Negociações da Agenda de Desenvolvimento Pós-2015: elementos orientadores da posição brasileira. 09 de setembro, 2014. Disponível em < http://www.itamaraty.gov.br/images/ed desenvsust/ODS-pos-bras.pdf $>$ Acessado em 25/03/2016.

BRASIL. Ministério da Cultura. Plano Setorial do Artesanato aberto a consulta pública. 02 de setembro, 2014. Disponível em <http://www.cultura.gov.br/noticias-destaques/lasset publisher/OiKX3xIR9iTn/content/plano-setorial-do-artesanato-aberto-a-consultapublica/10883.> Acesso em 25 jan 2016.

BRASIL. Ministério da Cultura. Plano da Secretaria da Economia Criativa: políticas, diretrizes e ações 2011 - 2014. 2ª edição (revisada). Brasília: Ministério da Cultura. 2011.

BRITO, Fausto. O deslocamento da população brasileira para as metrópoles. Estudos Avançados, São Paulo, v. 20, n. 57, p. 221-236, Aug. 2006. Disponível em: <http://www.scielo.br/scielo.php?script=sci_arttext\&pid=S0103$40142006000200017 \&$ Ing=en\&nrm=iso >. Acesso em: 15 de maio 2015. 
BRUM, M. Favelas e remocionismo ontem e hoje: da Ditadura de 1964 aos Grandes Eventos. O Social em Questão - Ano XVI - n. 29, p. 179-208, 2013.

BURSZTYN, M. (Org.). No meio da rua: nômades, excluídos e viradores. Rio de Janeiro: Garamond, 2003.

BURSZTYN, Marcel. O poder dos donos: planejamento e clientelismo no Nordeste. Rio de Janeiro: Garamond; Fortaleza: BNB, 2008. 272 p.

CALDEIRA, T. Espacio, segregación e arte urbano en el Brasil. Argentina: Katz Editores, 2010. $137 \mathrm{p}$.

CALDEIRA, T. P. R. Cidade de muros: crime, segregação e cidadania em São Paulo. São Paulo: Editora 34/EDUSP, 2000. 400 p.

CALDEIRA, T. P. R.; HOLSTON, J. Democracy and Violence in Brazil: Comparative Studies in Society and History, v. 41, n. 4, p. 691-729, out. 1999.

CANO, I. (Coord.). 'Os donos do morro': uma avaliação exploratória do impacto das Unidades de Polícia Pacificadora (UPPs) no Rio de Janeiro. São Paulo: Fórum Brasileiro de Segurança Pública; Rio de Janeiro: Laboratório de Análise da Violência - UERJ, 2012. Disponível em: <http://www.lav.uerj.br/docs/rel/2012/RelatUPP.pdf>. Acesso em: 10 ago. 2015.

CASTEL, R. A dinâmica dos processos de marginalização: da vulnerabilidade à “desfiliação”. CADERNO CRH, Salvador, n. 26/27, p. 19-40, jan./dez. 1997.

CASTELLS, M.; PORTES, A. World underneath: the origins, dynamics, and effects of the informal economy (p. 11-37). In: PORTES, A.; CASTELLS, M.; BENTON, L. A. (Eds). The Informal Economy: studies in advanced and less developed countries. The John Hopkins University Press, 1989.

CAVALLIERI, Fernando. LOPES, Gustavo Peres. Favelas cariocas: comparação das áreas ocupadas 1999-2004. Rio de Janeiro: Instituto Pereira Passos, 2006. n. 20061201:49 (Coleção Estudos Cariocas).

CAVALLIERI, Fernando. LOPES, Gustavo Peres. Índice de Desenvolvimento Social - IDS: comparando as realidades microurbanas da cidade do Rio de Janeiro. Rio de Janeiro: Instituto Pereira Passos, 2008. n. 20080401 (Coleção Estudos Cariocas). 
CENTRO NACIONAL DE FOLCLORE E CULTURA POPULAR. Promoart. Disponível em $<$ http://www.cnfcp.gov.br/interna.php?ID Secao=128>. Acesso em: 25 jan. 2016.

CEPAL. Coesão social: Inclusão e sentido de pertencer na América Latina e no Caribe. Síntese. Santiago do Chile: Cepal - Nações Unidas, 2007.

CEPAL Desarrollo social inclusivo: una nueva generación de políticas para superar la pobreza y reducir la desigualdad en América Latina y el Caribe. In: Conferencia Regional sobre Desarrollo Social de América Latina y el Caribe Lima, 2 a 4 de noviembre de 2015. Disponível em:

<http://repositorio.cepal.org/bitstream/handle/11362/39100/S1600099 es.pdf? sequence=4>

COELHO, D. O; CONCEIÇÃO, L. M. A.; PROVEnZA, M. M. Balanço de Indicadores de Política de Pacificação (2007-2014). Rio de Janeiro: Governo do Estado do Rio de Janeiro, Secretaria de Segurança, Instituto de Segurança Pública, 2015. Disponível em: <http://arquivos.proderi.ri.gov.br/isp imagens/Uploads/BalancodelndicadoresdaPoliciadePac ificacao2015.pdf>. Acesso em: 5 ago. 2015.

COLEMAN, J. Social Capital in the creation of human capital. The American Journal of Sociology, v. 94, Supplement: Organizations and Institutions Sociological and Economic Approaches to the Analysis of Social Structure. University of Chicago Press. 1988 pp. S95 S120.

COSTA, A. T. M. Entre a lei e a ordem: violência e reforma nas polícias do Rio de Janeiro e Nova York. Rio de Janeiro: FGV, 2004.

CUNHA, N. V.; MELLO, M. A. da S., A UPP e o processo de urbanização na favela Santa Marta: notas de campo. In: MELLO, Marco Antônio da Silva et al. (Org). Favelas cariocas: ontem e hoje. Rio de Janeiro: Garamond, 2012. p. 433 a 474.

DAHLBERG, L. L.; KRUG, E.G. Violência: um problema global de saúde pública. In: Ed(s) Etienne G. Krug et al. Relatório Mundial sobre Violência e Saúde. Genebra: Organização Mundial de Saúde, 2002, p.1-22.

DALL'ACQUA, Fernando Maida. Estrutura agrária e liberação de mão-de-obra agrícola no Estado de São Paulo. Revista de Administração de Empresas, São Paulo, v. 16, n. 6, p. 5160, Dec. 1976. Disponível em: http://www.scielo.br/scielo.php?script=sci_arttext\&pid=S003475901976000600006\&lng=en\&nrm=iso $>$ Acesso $\quad 15$ maio. 2015. http://dx.doi.org/10.1590/S0034-75901976000600006. 
DAVIS, Mike. Planet of slums. London • New York: Verso, 2006.

Diário Oficial do Município do Rio de Janeiro, Decreto nº 33.347, de 3 de janeiro de 2011.

ESCOREL, Sarah. Exclusão Social. In: Dicionário da Educação Profissional em Saúde. Fundação Oswaldo Cruz/Escola Politécnica de Saúde Joaquim Venâncio. Rio de Janeiro: 2009. Disponível em: : <http://www.sites.epsjv.fiocruz.br/dicionario/verbetes/excsoc.html>. Acesso em: 15 maio. 2015.

FERNANDES, A. Paes rebatiza ação social em UPPs para superar estigma. O Dia, Rio de Janeiro, 9 de ago. 2014. Disponível em: http://odia.ig.com.br/noticia/rio-de-janeiro/2014-0809/paes-rebatiza-acao-social-em-upps-para-superar-estigma.html

FISCHER, B. A poverty of rights: citizenship and inequality in Twentieth-Century. Rio de Janeiro. Stanford, Califórnia: Stanford University Press, 2008.

FORTUNA, P. Sebrae estimula crescimento do empreendedorismo nas favelas. Agência Sebrae, 3 de março, 2015. Acesso em: 15 de março de 2015.

FÓRUM NOVA FAVELA BRASILEIRA, 2ํㅡ, 2015, São Paulo. As Favelas no Brasil: percepções e perspectivas (apresentação). Disponível em < http://www.sebrae.com.br/Sebrae/Portal\%20Sebrae/UFs/AM/Anexos/Apresenta\%C3\%A7\%C 3\%A30 2\%C2\%BA\%20Forum\%20Favela Consolidado.pdf>. Acesso em: 10 de novembro de 2015.

FRANÇA FILHO, G. C; LAVILLE, J.-L. Economia solidária: uma abordagem internacional. Porto Alegre: UFRGS, 2004.

GODOY, A. S. Estudo de caso qualitativo. In: Pesquisa Qualitativa em Estudos Organizacionais: paradigmas, estratégias e métodos. São Paulo: Saraiva, 2006.

GOLDENBERG, M. A arte de pesquisar: como fazer pesquisa qualitativa em Ciências Sociais. 5 ${ }^{\mathrm{a}}$ ed., Rio de Janeiro: Record, 2001.107 p.

GLAESER, Edward L. Os centros urbanos: a maior invenção da humanidade: como as cidades nos tornaram mais ricos, inteligentes, saudáveis e felizes. Rio de Janeiro: Elsevier, 2011.

GRILLO, M. Segurança Pública: UPPs mudam conceito de policiamento nas comunidades. O Globo, Rio de Janeiro, p. 8, 27, jul. 2015. 
GRILLO, Marco. Projeto que prevê série de ações em comunidades cariocas será mantido, afirma prefeitura. O Globo, Rio de Janeiro, 29 set. 2015.

HENRIQUES, Ricardo; RAMOS, Silvia. UPPS Sociais: ações sociais para consolidar a pacificação. In: URANI, André; GIAMBIAGI, Fábio (Orgs.). Rio: a hora da virada. Rio de Janeiro: Elsevier, 2011, cap. 18. p. 242-254.

IBGE. Áreas de Divulgação da Amostra para Aglomerados Subnormais. Nov. 2013.

IBGE. Censo 2010 Aglomerados Subnormais: informações territoriais. IBGE. Disponível em:

http://www.ibge.gov.br/home/presidencia/noticias/imprensa/ppts/0000001516481120201348 0105748802.pdf. Acesso em 15 maio 2015.

IBGE. Estatística de Gênero: uma análise dos resultados do Censo Demográfico 2010. Estudos \& Pesquisas, ㄲo 33, IBGE, 2014.

INSTITUTO DE ESTUDOS DO TRABALHO E SOCIEDADE (IELTS); SEBRAE. Pesquisa sobre Microempreendedorismo em Domicílios nas Favelas com Unidades de Polícia Pacificadora. Rio de Janeiro: SEBRAE. 7 de dezembro, 2012 ${ }^{a}$. Disponível em: (http://www.sebrae.com.br/Sebrae/Portal\%20Sebrae/UFs/RJ/Menu\%20Institucional/SEBRA E_EMP_dez12_MicroEmp_UPP.pdf). Acesso: 15 de agosto, 2015.

INSTITUTO DE ESTUDOS DO TRABALHO E SOCIEDADE (IELTS); SEBRAE. Perfil e dinâmica dos pequenos negócios em territórios do Rio de Janeiro com UPP, Publicação semestral, n.4, Rio de Janeiro: SEBRAE, $2012^{\mathrm{b}}$.

INSTITUTO DE ESTUDOS DO TRABALHO E SOCIEDADE (IELTS). Parâmetros e Resultados da PNAD 2014. 7 dez. 2015. Disponível em: http://www.iets.org.br/dado/parametros-e-resultados-da-pnad-2014. Acesso em 2 de novembro, 2015.

IPEA. Mercado de trabalho conjuntura e análise, ano 17, fev. 2012 - Brasília: Ipea / MTE.

JACOBS, Jane. Morte e vida de grandes cidades. São Paulo: Martins Fontes, 2000.

KOWARICK, Lúcio. Capitalismo, dependência e marginalidade urbana na América Latina: uma contribuição teórica. Estudos CEBRAP, São Paulo, número 08, Abril de 1974, pp 78-96. 
LEAL, M. T. Rocinha fashion: como cem mulheres moradoras do morro carioca ganharam fama no mundo da moda. Depoimento [8 nov. 2006]. Brasília: Revista Desafios do Desenvolvimento, IPEA, Ano 3 . Edição 28. Depoimento concedido a Gustavo de Paula. Disponível em: < http://www.ipea.gov.br/desafios/index.php?option=com content\&view=article\&id=2209:catid $=28 \&$ ltemid $=23>$. Acesso em: 10/11/2015.

LEITÃO, Andreza Barreto; GANTOS, Marcelo Carlos. Economia criativa, políticas públicas e sociais e inserção produtiva: um estudo sobre o setor do artesanato no norte fluminense. In: I Congresso Internacional Interdisciplinar em Sociais e Humanidades, 2012, Niterói - Rio de Janeiro. Anais.

LEITE, Carlos; AWAD, Juliana di Cesare Marques. Cidades sustentáveis, cidades inteligentes: desenvolvimento sustentável num planeta urbano. Porto Alegre: Bookman, 2012, p. 264.

LEMGRUBER, J. A primeira mulher a dirigir o sistema penitenciário do RJ conta como ser mãe a ajudou na profissão. Entrevista [12 de nov. de 2010]. São Paulo: Revista TPM. Entrevista concedida a Ariane Abdallah. Disponível em: $<$ http://revistatpm.uol.com.br/revista/104/paginas-vermelhas/julita-lemgruber.html>. Acesso em: 10 ago. 2015.

LERNER; ARQUITETOS ASSOCIADOS <http://www.jaimelerner.com/escritório.html>. Acesso em: 5 dez. 2015.

LERNER, J. Bate papo com Jaime Lerner: depoimento [29/02/2012]. Raphael Toscano: arquitetura e urbanismo. Disponível em: < https://raphaeltoscano.wordpress.com/tag/cidade/>. Acesso em: 3 dez. 2012.

MADEIRA, M. G. Economia criativa: Implicações e desafios para a política externa. Brasília: FUNAG, 2014.

MCCANN, B. Hard times in the Marvelous City: from dictatorship to democracy in the favelas of Rio de Janeiro. Duke University Press - Durham and London, 2014.

MEIRELLES , R.; ATHAYDE,C. Um país chamado favela. São Paulo: Editora Gente, 2014.

MENDONÇA, A.V. Lula lança projeto piloto de turismo em favela pacificada do Rio de Janeiro. Portal do G1. 30/08/2010. Disponível 
http://g1.globo.com/politica/noticia/2010/08/lula-lanca-projeto-piloto-de-turismo-em-favelapacificada-no-rio.html. Acesso: 25 de janeiro de 2016.

MINAYO, M. C. A lógica da guerra e os confrontos armados nas favelas cariocas: entrevista [20 de agosto de 2013]. Entrevistador: Silvana Bahia. Rio de Janeiro. 2013. Entrevista concedida ao Observatório das Favelas. Disponível em: <http://of.org.br/noticias-analises/alogica-da-guerra-e-os-confrontos-armados-nas-favelas-cariocas/>. Acesso em: 25 ago. 2015.

MINAYO, M. C; SOUZA, E. R. de. Violência e Saúde como um campo interdisciplinar e de ação coletiva. História, Ciências, Saúde-Manguinhos, v. IV, ano 3, p. 513-531, nov.1997.

MINISTÉRIO DA JUSTIÇA. Mulheres da Paz e Protejo. 2012. Disponível em: <http://portal.mj.gov.br/data/Pages/MJ34F31E13ITEMID4D3527BC648B4139BF88C5980C1 6ECC8PTBRNN.htm>. Acesso em: 15 ago. 2015.

MINISTÉRIO DA SAÚDE. Secretaria de Políticas de Saúde. Projeto Promoção da Saúde. As Cartas da Promoção da Saúde. Brasília: Ministério da Saúde, 2002. 56 p. (Série B. Textos Básicos em Saúde).

NASCIMENTO, 2003. Dos excluídos necessários aos excluídos desnecessários. In: Bursztyn, M. (org.). No meio da rua: nômades, excluídos e viradores. Rio de Janeiro: Garamond, 2003. Cap. 2, p. 56-87.

NAS COMUNIDADES PACIFICADAS, O MERCADO INTEGRA. Revista Economia Rio, ano 01, edição 04. Rio de Janeiro: IBMEC. 2014

NERI, M. (Coord.). Desigualdades e Favelas Cariocas: a cidade partida está se integrando?. Rio de Janeiro: FGV/CPS. 2010, 146p.

NERI, M. (Coord.). UPP² e a Economia da Rocinha e do Alemão: do choque de ordem ao progresso. Centro de Políticas Sociais, Fundação Getúlio Varga, 22 de novembro de 2011.

NUNES, B.; MOURA, H. V. Imaginário urbano e conjuntura no Rio de Janeiro. Urbe Revista Brasileira de Gestão Urbana, v. 5, n. 1, p. 91-105, jan/jun. 2013.

NUNES, B.; VELOSO, L. Guetos e favelas: recorrência do "déficit" de territórios nas metrópoles contemporâneas. In: Encontro Anual da ANPOCS, 34, 2010 , Caxambu (MG), Anais, p. 1-27. 
NUNES, Joana. Formulação e implementação da UPP Social carioca: os desafios de transformar ideias em práticas. Tese de Doutorado. PPED-IE/UFRJ, Rio de Janeiro, 2013.

OBSERVATÓRIO DAS FAVELAS; REDES DE DESENVOLVIMENTO DA MARÉ. Censo de empreendimentos da Maré, 2014.

OLIVEIRA, F.L. de; ABRAMOVAY, P.V. As UPPs e o longo caminho para a cidadania nas favelas do Rio de Janeiro. Cap. 5. p. 123-148. In: OLIVEIRA, F. L. de (org). UPPs, Direito e Justiça: um estudo de caso das favelas do Vidigal e do Cantagalo. Rio de Janeiro: FGV, 2012.

ORGANIZAÇÃO MUNDIAL DE SAÚDE. Constituição da Organização Mundial da Saúde (OMS/WHO) - 1946. Disponível em: <http://www.direitoshumanos.usp.br/index.php/OMSOrganiza\%C3\%A7\%C3\%A3o-Mundial-da-Sa\%C3\%BAde/constituicao-da-organizacaomundial-da-saude-omswho.html>. Acesso em: 25 ago. 2015.

ORGANIZAÇÃO MUNDIAL DE SAÚDE. Relatório Mundial sobre Violência e Saúde. Editores: Krug, E. G.; Dahlberg, L. L.; Mercy, J. A.; Zwi, A. B. e Lozano, R.. Genebra, 2002.

ORGANIZAÇÃO DAS NAÇÕES UNIDAS. World Economic and Survey 2013: Sustainable Development Challenges. New York: United Nations. 2013 Disponível em: <http://www.un.org/en/development/desa/policy/wess/wess current/wess2013/WESS2013.p df $>$. Acesso em: 30/4/2016.

ORGANIZAÇÃO DAS NAÇÕES UNIDAS. Relatório Promoção e Proteção de todos os Direitos Humanos, Civis, Políticos, Econômicos, Sociais e Culturais incluindo o direito ao desenvolvimento. Philip Alston, 29 de agosto de 2008. Disponível em:

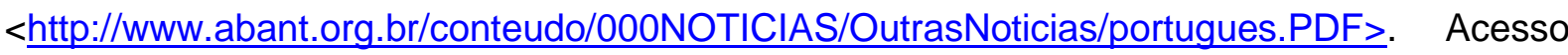
em: 15/04/2016.

PANDOLFI e GRYNSZPAN (orgs.) A Favela Fala: depoimentos ao CPDOC, Rio de Janeiro: FGV, 2003, (364p)

PARK, Robert E. Human migration and the marginal man. American Journal of Sociology, vol. 33, n. 6, May 1928, University of Chicago Press, p. 881-893.

PARK, Robert E., BURGESS, Ernest W. The sociological significance of the stranger. Introduction to Science of Sociology. Chicago: University of Chicago Press, 1921, p.322-327. 
PAUGAM, Serge. O enfraquecimento e a ruptura dos vínculos sociais: uma dimensão essencial do processo de desqualificação social. p. 67-86. In: SAWAIA, B. (Org.). As artimanhas da exclusão social: análise psicossocial e ética da desigualdade social. Petrópolis: Vozes, 2001.

PAULA, Nice de. O desafio de empreender nas áreas pacificadas. $O$ Globo, 17 de outubro, 2013.

PAULO, P. P. Ponha-se na Rua: há 200 anos é assim que o governo lida com as comunidades cariocas. Entrevista [23 de abril de 2013]. Entrevista concedida à Agência Pública. Disponível em: http://apublica.org/2013/04/ponha-se-na-rua-mais-de-200-anos-deremocoes-compulsorias-rio-de-janeiro/. Acesso em: 10 de outubro de 2015

PEREIRA, I. N. Efeituação situada: redes e empreendedorismo na Rocinha. Tese de Doutorado. COPPE/ UFRJ, Rio de Janeiro, 2014.

Pereira; Medronho; Escosteguy; Valencia; Figueiredo; Magalhães. Distribuição espacial e contexto socioeconômico da tuberculose, Rio de Janeiro, Brasil. Revista Saúde Pública $2015 ; 49: 48$.

PERLMAN, J. Favela: Four decades of living on the edge in Rio de Janeiro. New York: Oxford University Press, 2010.

PERLMAN, J. Marginalidade: Do mito à realidade nas favelas do Rio de Janeiro - 19692002. In: Encontro Nacional da Anpur, X, 2003, Belo Horizonte (Anais).

PERLMAN, J. Marginality: From Myth to Reality in the Favelas of Rio de Janeiro, 1969 2002). In: ROY, Ananya; ALSAYYAD, Nezar (eds.). Urban Informality: transnational Perspectives from the Middle East, Latin America, and South Asia. Lanham: Lexington Books, 2004.

PERLMAN, Janice. Favelas ontem e hoje (1969 - 2009). In: MELLO, Marco Antônio da Silva et al. (Org). Favelas cariocas: ontem e hoje. Rio de Janeiro: Garamond, 2012.

PERLMAN, Janice. O mito da marginalidade: favelas e política no Rio de Janeiro. São Paulo: Paz e Terra, 1977. 
PINHEIRO, P. S. Prefácio. In: ALVES, M. H. M. Vivendo no fogo cruzado: moradores de favela, traficantes de droga e violência policial no Rio de Janeiro. São Paulo: Unesp, 2013. Tradução de: Living in the Crossfire.

PORTES, Alejandro. Capital social: origens e aplicações na sociologia contemporânea. Sociologia, Problemas e Práticas, n. 33, 2000, p. 133-158.

PUTNAM, Robert D. Comunidade e democracia: a experiência da Itália moderna. 2. ed. Rio de Janeiro: FGV, 2000.

Ramos, S.; Lemgruber, J. Criminalidade e respostas brasileiras à violência. Observatório da

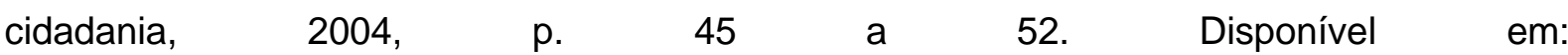
<http://www.comunidadesegura.org.br/files/criminalidadeerespostasbrasileirasaviolenciaram oselengruber.pdf>. Acesso em: 6 ago. 2015.

RIO DE JANEIRO (Estado). Secretaria de Segurança do Estado do Rio de Janeiro. UPP: o que é? Rio de Janeiro: Governo do Rio de Janeiro. Disponível em: <http://www.upprj.com/index.php/o_que_e_upp>. Acesso em: 14 ago. 2015 .

RIO DE JANEIRO (Estado). Secretaria de Segurança do Estado do Rio de Janeiro. UPP: histórico. Rio de Janeiro: Governo do Rio de Janeiro. Disponível em: <http://www.upprj.com/index.php/historico>. Acesso em: 14 ago. $2015^{\text {a }}$.

RIO DE JANEIRO (Estado). Secretaria de Segurança do Estado do Rio de Janeiro. UPP: números. Rio de Janeiro: Governo do Rio de Janeiro. Disponível em: <http://www.upprj.com>. Acesso em 14 de agosto $2015^{c}$.

RIO DE JANEIRO (Estado). Empresa de Obras Públicas do Estado do Rio de Janeiro. Complexo da Rocinha - Rio de Janeiro (Relatório Final): Censo Empresarial, 2010. Disponível em: < http://www.emop.ri.gov.br/wp-content/uploads/2014/06/CENSOEMPRESARIAL-ROCINHA.pdf >. Acesso em 3/3/2015.

RIO DE JANEIRO (Estado). Empresa de Obras Públicas do Estado do Rio de Janeiro. Plano de Desenvolvimento Sustentável da Rocinha. 12/08/2011. Disponível em: < http://www.emop.ri.gov.br/wp-content/uploads/2014/06/PDS-Rocinha.pdf $>$. Acesso em 3/3/2015.

RIO DE JANEIRO (Prefeitura/IPP) ${ }^{a}$. Ações da Prefeitura em Áreas Pacificadas. Acesso: 2 de janeiro 2015. Disponível em: http://www.riomaissocial.org/mapa-riomaissocial/ 
RIO DE JANEIRO (Prefeitura/IPP) ${ }^{b}$ Indicadores sociais e econômicos por bairros e comunidades selecionadas da cidade do Rio de Janeiro - 2000. Rio de Janeiro: Armazém dos Dados. Disponível em: http://portalgeo.rio.rj.gov.br/indice/flanali.asp?codpal=1174\&pal=\%CDNDICE\%20DE\%20DE SENVOLVIMENTO\%2OHUMANO\%2OMUNICIPAL\%20-\%20IDH-M. Acesso em: 10/11/2015.

RIO DE JANEIRO (Prefeitura). Desenvolvimento Humano e condições de vida na cidade do Rio de Janeiro. CARDOSO, A. (Coord). Coleção Estudos Cariocas, № 20040101, Janeiro 2004. IUPERJ/IPEA/IPP/Prefeitura da Cidade do Rio de Janeiro, 2004.

RIO DE JANEIRO (Prefeitura). CARDOSO, A. (Coord.). A Cidade do Rio de Janeiro na PNAD: Condições de Vida, Educação, Renda e Ocupação entre 2001 e 2006. Coleção Estudos Cariocas, № 20080802, Agosto - 2008. IPP/ Prefeitura da Cidade do Rio de Janeiro.

RIO DE JANEIRO (Prefeitura)a. CAVALLIERI, F.; VIAL, A. Favelas na cidade do Rio de Janeiro: o quadro populacional com base no Censo 2010. Coleção Estudos Cariocas, № 20120501, Maio - 2012, IPP/Prefeitura da Cidade do Rio de Janeiro.

RIO DE JANEIO (Prefeitura)b. CAVALLIERI, F.; VIAL, A. A nova classificação de favelas para o planejamento das políticas públicas. In: Conselho Estratégico de Informações da Cidade: ata de reuniões. 12 de setembro de 2012, IPP/Prefeitura da Cidade do Rio de Janeiro.

RIO DE JANEIRO (Prefeitura)c. CAVALLIERI, F.; LOPES, G. P.. Índice de Desenvolvimento Social - IDS: comparando as realidades micro urbanas da cidade do Rio de Janeiro. Coleção Estudos Cariocas, № 20080401 Abril - 2008, IPP/Prefeitura da Cidade do Rio de Janeiro.

SEBRAE. Comunidades pacificadas viram celeiros de pequenos negócios. Sebrae Nacional, 2014. Disponível em: http://www.sebrae.com.br/sites/PortalSebrae/artigos/comunidadespacificadas-viram-celeiros-de-pequenosnegocios,6eea6a1f07fb6410VgnVCM2000003c74010aRCRD. Acesso em: 07/12/2015.

SEBRAE. Programa de desenvolvimento do empreendedorismo em comunidades pacificadas (Coords. Israel Jorge, Carla Geraldo de Morais Teixeira). Rio de Janeiro, 2014, $119 \mathrm{p}$. 
SEN, Amartya. Desenvolvimento como liberdade. São Paulo: Companhia das Letras, 2004.

SILVA a , J. da. Operação Rio. Antes da Rio+20: para não esquecer o papel da mídia. 2. ed. Rio de Janeiro: Forense, 2008. Disponível em: <http://www.jorgedasilva.com.br/artigo/52/>. Acesso em: 5 ago. 2015.

SILVA ${ }^{b}$, J. da. Favelas e violência no Rio: sem conflitos, entre o sonho e o pesadelo da apartação. In: Mello, M. A. da S. (et al). Favelas cariocas: ontem e hoje. Rio de Janeiro: Garamond, 2012. p. 393-413.

SILVA $^{c}$, J. S. As unidades policiais pacificadoras e os novos desafios para as favelas cariocas. In: MELLO, M. A. da S. et al (Org.). Favelas cariocas: ontem e hoje. Rio de Janeiro: Garamond, 2012. p. 415-432.

SILVA $^{\text {d, }}$ L. C. Ecolimite e contenção de favela: o caso do muro da favela Santa Marta. In: Encontro Nacional ANPUR, XVI, 2015, Belo Horizonte (Anais - Sessões Temáticas ST4).

SIMMEL,, Georg. [1908] 1971. "The Stranger." p. 143-149. In: LEVINE, D. N. (Ed.) On Individuality and Social Forms. Chicago: University of Chicago Press.

SIMONI, Jane. Novas economias enraizadas em iniciativas locais. Sustentabilidade em Debate, Brasília, v. 2, n. 2, 2011.

SINGER, P. Introdução à economia solidária, $1^{a \underline{a}}$ edição, São Paulo: Editora Fundação Perseu Abramo, 2002.

SINGER, P. A construção da economia solidária como alternativa ao capitalismo, 2013. Disponível: http://www.socioeco.org/bdf fiche-document-1890 pt.html

SOARES, L. E. Prefácio. In: MEIRELLES, R.; ATHAYDE, C. Um País chamado Favela: a maior pesquisa já feita sobre a favela brasileira. São Paulo: Editora Gente, 2014.

SOARES, L. E.. O Brasil tem que acabar com as PMs: depoimento. [23 de outubro de 2013]. Isto é Independente. Entrevista concedida a Wilson Aquino e Michel Alecrim. Disponível em http://www.istoe.com.br/assuntos/entrevista/detalhe/331480 O+BRASIL+TEM+QUE+ACAB $\underline{A R+C O M+A S+P M S}+$. Acesso em 14/04/2016.

TANCREDI, F. B.; BARRIOS, S. R. L.; FERREIRA, J. H. G. Planejamento em saúde. São Paulo: Faculdade de Saúde Pública da Universidade de São Paulo, 1998. 2v. (Série Saúde \& Cidadania). 
TAVARES, D. Ministério da Justiça libera $R \$ 8$ milhões para a economia solidária em favelas do Rio, (2 de dezembro, 2010). Agência Sebrae de Notícias. Disponível em <http://www.df.agenciasebrae.com.br/sites/asn/uf/DF/Minist\%C3\%A9rio-da-Justi\%C3\%A7alibera-R\$-8-milh\%C3\%B5es-para-a-economia>-solid\%C3\%A1ria-em-favelas-do-Rio>. 2/12/2010. Acesso em: 30 de jan. 2016.

TEIXEIRA, M. História do Bairro: Morro Santa Marta. Disponível em: $<w w w . a m a b o t a f o g o . o r g . b r / h i s t o r i a / s a n t a \_m a r t a . a s p>$. Acesso em 3/3/2015.

URANI, A. Trilhas para o Rio: do reconhecimento da queda à reinvenção do futuro. Cidade: Elsevier, 2008, 226 p.

URANI, André, GIAMBIAGI, Fábio (orgs.). Rio: a hora da virada. Rio de Janeiro: Elsevier, 2011.

VALLADARES, L. P. A invenção da favela: do mito de origem a favela.com. Rio de Janeiro, FGV, 2005.

VARGAS, A. et al. Pesquisa sobre Microempreendedorismo em Domicílios nas Favelas com Unidades de Polícia Pacificadora. IETS/SEBRAE. 2012.

VENTURA, Roberto. Canudos como cidade iletrada: Euclides da Cunha na urbs monstruosa. Revista de Antropologia. São Paulo , v. 40, n. 1, p. 165-181, 1997

Disponível em <http://www.scielo.br/scielo.php?script=sci arttext\&pid=S003477011997000100006\&lng=en\&nrm=iso> $\quad$ Acesso em on 01 Apr. 2016. http://dx.doi.org/10.1590/S0034-77011997000100006.

VENTURA, Zuenir. Cidade partida. São Paulo: Companhia das Letras, 1994.

VÉRAS, Maura Pardini Bicudo. Exclusão Social - Um problema de 500 anos. Notas preliminares. p. 27-50. In.: SAWAIA, B. (org.). As artimanhas da exclusão social: análise psicossocial e ética da desigualdade social. Petrópolis: Vozes, 2001.

VIVA RIO. Relatório de experiências de enfrentamento da violência em perspectiva comparada: os casos de Rio de Janeiro, Salvador, Curitiba e Cidade do Panamá. 10/09/2014.

VIVA RIO. Quem somos. Disponível em < http://vivario.org.br/quem-somos-2>. Acesso em: 05/04/2015). 
VIVA RIO. Favela tem memoria: os filhos do arara-porto. Disponível em: $<$ http://favelatemmemoria.com.br/os-filhos-do-arara-porto>. Acesso: 01/02/2016.

WANDERLEY, Mariangela Belfiore. Refletindo sobre a noção de exclusão. p. 16-26. In: SAWAIA, B. (org.). As artimanhas da exclusão social: análise psicossocial e ética da desigualdade social. Petrópolis: Vozes, 2001.

WIRTH, Louis. O urbanismo como modo de vida. In: VELHO, Otávio Guilherme. (Org.). 0 fenômeno urbano. Rio de Janeiro: Zahar, 1967.

WAISELFISZ, Julio Jacobo. Mapa da Violência - 2012: os novos padrões da violência homicida no Brasil. 1ª ed. São Paulo: Instituto Sangari, 2011.

YIN, Robert K. Estudo de caso: planejamento e métodos. Trad. Daniel Grassi. 3.ed. Porto Alegre: Bookman, 2005. 212 p.

SEN, A. Desenvolvimento como liberdade. São Paulo: Companhia das Letras. 2000. $411 \mathrm{p}$.

ZALUAR, A.; ALVITO, M. Um século de favelas. 2006.

ZALUAR, Alba; ALVITO, Marcos. Introdução. In: ZALUAR, Alba; ALVITO, Marcos (Org.). Um século de favela. 5 . ed. 2006, $372 \mathrm{p}$.

ZAOUAL, Hassan. Nova economia das iniciativas locais: uma introdução ao pensamento pós-global. Rio de Janeiro: DP\&A: Consulado-Geral da França: COPPE/UFRJ, 2006.

ZAOUAL, Hassan. O homo situs e suas perspectivas paradigmáticas. OIKOS, v. 9, n. 1. Rio de Janeiro: 2010, p. 13-39. 
ANEXOS:

Roteiro das entrevistas

1) Entrevista com Cláudia Leitão, Secretária de Economia Criativa do Ministério da Cultura.

Roteiro:

1. Por que a economia criativa passou a ter status de Secretaria no governo Dilma?

2. O apoio à produção artesanal é uma política transversal que perpassa diversas pastas do governo federal. Que ações estão previstas para apoio a esta atividade pela Secretaria de Economia Criativa?

3. A atividade artesanal realizada em favelas urbanas serão, também, contempladas por essas políticas?

4. De que forma a economia criativa se relaciona com a economia solidária?

5. Qual a importância da atividade artesanal para o desenvolvimento local?

2) Entrevista com Valmor Schiochet, diretor do Departamento de Estudos e Divulgação - SENAES/MTE

Roteiro inicial:

1. Quais as principais ações políticas da Secretaria voltadas ao fomento desse tipo de trabalho (artesanal)?.

2. Qual a importância do trabalho artesanal no âmbito da economia solidária?

3. De que forma o MTE atua no fortalecimento das relações da comunidade com os agentes de desenvolvimento (bancos públicos, Sebrae, agências de fomento da economia solidária, instituições ligadas à lgreja, sindicados, movimentos sociais ....);

4. Existe uma ação política direcionada à preparação desses agentes para atuar com essas comunidades?

3) Entrevista com Georgia Haddad Nicolau, Diretora de Empreendimento Gestão e Inovação, Secretaria de Políticas Culturais, Ministério da Cultura.

1. Vocês estão passando por uma reestruturação. Com a extinção da Secretaria de Economia Criativa, criada na gestão ministerial anterior, como fica a coordenação da política do artesanato no Minc?

1.a. Quando isso aconteceu?.

1b. Quais foram as principais ações da Secretaria de Economia Criativa?

1c. E em relação, especificamente, ao artesanato? 
2. Como foi dito no Plano da Secretaria de Economia Criativa (2011-2014), o escopo das políticas públicas do MinC estava voltado a setores de natureza tipicamente cultural.

Recentemente esse escopo foi ampliado, passando a contemplar, também, setores como o artesanato, considerado de aplicabilidade funcional (BRASIL, 2011, p.30). Qual a importância, hoje, desse setor do artesanato no Minc?

3. Como vocês pretendem apoiar e fomentar o artesanato na atual gestão?

4. De acordo com a ONU, o artesanato é um dos setores criativos nucleares da economia criativa. No entanto, quando se fala de economia criativa, o foco parece se voltar principalmente à indústria criativa de audiovisual. Qual o peso (a importância) que o artesanato terá dentro da nova estrutura organizacional do MinC?

5. Agora abordarei uma questão mais conceitual. Quando entrevistei a ex-secretária de Economia Criativa, Cláudia Leitão, ela sublinhou a relação da economia criativa com a inclusão social e a sustentabilidade. Cláudia Leitão explicou a inclusão social, nesse caso, como resultado da geração de trabalho e renda por meio do setor criativo. A

sustentabilidade, por sua vez, seria resultado dessa possibilidade de promoção da inclusão social e, também, pelo fato da economia criativa ser um setor baseado em um recurso que não é limitado pela noção de escassez nem é poluidor. Em minhas idas a campo vi que há diversos trabalhos nas favelas que se encaixam nessas premissas da inclusão social e sustentabilidade. Isso poderia ser considerado uma contribuição brasileira ao conceito da economia criativa?

3) Depois de realizada a entrevista com Georgia Haddad Nicolau , agendada pela Assessoria de Imprensa do MinC, resolvi procurar por conta própria outras fontes de informação no MinC. Sem agendamento prévio, procurei a Secretaria de Cidadania e da Diversidade Cultural. Lá conversei com a coordenadora de Comunicação e Difusão, Fernanda Quevedo, que me indicou Rejane de Cássia Barbosa da Nóbrega, coordenadora do Colegiado do Artesanato no MinC. Fiz a entrevista sem um roteiro prévio, formulando perguntas a partir das informações obtidas anteriormente. Ainda nesse mesmo dia, encontrei a secretária de Cidadania e de Diversidade Cultural, Ivana Bentes, com quem estudei na faculdade e, também, colhi seu depoimento sem roteiro prévio.

\section{4) Entrevista com Ana Beatriz Ellery, coordenadora do Programa do Artesanato Brasileiro, Secretaria de Micro e Pequena Empresa.}

1. Um bom ponto de partida para a nossa entrevista é a diferenciação entre artesanato e trabalho manual. Você estava dizendo que a costura não é considerada artesanato para vocês, e que a Secretaria de Economia Solidária trabalha com um conceito mais fluido. Então eu gostaria de saber o que vocês classificam como artesanato?

2. Existe uma coordenação política para o artesanato?

3. Vocês têm uma coordenação que perpassa de forma transversal para os outros ministérios. Como é que seria isso?

4. Vc acha possível desenvolver uma identidade cultural ou essa identidade teria que ser uma tradição? Estou pensando nos grupos que entrevistei nas favelas. Por exemplo, tem um grupo na Rocinha constituído por mulheres quase todas nordestinas ou descendentes. Elas carregam consigo a tradição do saber fazer, como, por exemplo, o saber fazer bordado. 
Muitas dessas mulheres já moram há muitos anos no Rio de Janeiro, outras nasceram no Rio. Não teria sentido que o artesanato por elas produzido tenha a identidade cultural vinculada apenas ao Nordeste. No entanto, para que a produção delas identifique o lugar em que vivem, elas teriam que desenvolver uma identidade cultural em relação ao Rio de Janeiro. Você acha que é possível que isso aconteça? Que seja possível desenvolver uma nova identidade cultural a partir de outras raízes?.

5. Conheci um grupo de artesãs na favela Babilônia, no Leme, no qual as mulheres não tiveram a influência de um designer e estão tentando desenvolver em seus produtos uma identidade local pintando própria, bordando, por exemplo, casinhas de favela. Já outro grupo da Rocinha teve acesso a um designer para lhe orientar a produção. Gostaria que você falasse um pouco mais sobre o receio, que vocês têm, da influência do designer sobre a produção artesanal.

6. Quais seriam as principais ações do Programa de Artesanato Brasileiro?

7. Com que frequência as feiras ocorrem?

8. A Feira Nacional ocorre em vários locais?

9. Desde quando o artesanato saiu do MDIC e veio para essa Secretaria. Fale um pouco da mudança de status que houve na Secretaria no atual governo.

10. Vocês têm uma preocupação com a importância do artesanato para a inclusão social, mais especificamente com a produção artesanal realizada por mulheres em situação de vulnerabilidade social?

11. Existe uma preocupação em aumentar o valor agregado do artesanato?

12. O que vocês fazem para isso, em termos de políticas públicas?

13. Vocês têm políticas voltadas à expansão do mercado do artesanato, visando o mercado externo?

14. A existência de uma certificação para os produtos ajudaria a colocação da produção lá fora?

15. Na semana passada (22 de outubro de 2015) foi sancionada pela Presidência da República a lei do artesão, que regulamenta a profissão. Gostaria que você falasse um pouco sobre essa lei e sua importância.

16. No MinC está sendo elaborado um Plano Setorial do Artesanato e aqui na Secretaria de Micro e Pequena Empresa há o Plano Brasileiro do Artesanato. Há alguma comunicação a esse respeito entre os ministérios?

5) Entrevista com Ana Asti - Diretora de Economia Solidária e Comércio Justo da Secretaria Especial de Desenvolvimento Econômico Solidário (SEDES) da Prefeitura do Rio de Janeiro.

Obs.: Entrevistamos Ana Asti em dois momentos (abril e novembro de 2015) 
1. Em julho de 2012, foi instituída a política de fomento à economia solidária no âmbito da Prefeitura, mas a SEDES foi criada em 2009. Desde quando pode se dizer que começaram as ações voltadas ao apoio ao trabalho artesanal em comunidades carentes?

2. Quais as ações desenvolvidas nos Pontos Solidários? As pessoas comercializam seus produtos nesses locais?

3. Quais as principais ações de fomento ao trabalho artesanal, desenvolvidas pela SEDES, que você destacaria?

4. Em termos de investimento, quanto já foi investido? Quais resultados alcançados?

5. O Pronasci ainda existe?

6. Em sua opinião, qual é a importância dessa política de fomento à economia solidária para uma cidade como a do Rio de Janeiro?

7. Quantos grupos de empreendedores foram contemplados pelo projeto Rio Ecosol?

8. Nas ações da economia solidária, parece existir um foco especial nas mulheres. Por quê?

9. Quais os critérios para participar do circuito de feiras da economia solidária? Existe alguma diferenciação entre artesanato e trabalho manual para a seleção dos trabalhos?.

Vi que a Secretaria Nacional de Economia Solidária não faz diferenciação entre artesanato e trabalho manual, mas a Secretaria de Micro e Pequena Empresa faz. Agora essa Secretaria (de Micro e Pequena Empresa) está demonstrando uma preocupação com o trabalho manual, embora não seja o foco de suas ações. Então abriram uma ala especificamente dedicada a esse tipo de trabalho nas feiras nacionais de artesanato brasileiro, que é uma grande vitrine do artesanato.

10. Como falar de identidade cultural local quando tratamos de grupos de artesãs que herdaram toda a cultura do lugar de origem de suas famílias, mas que há anos construíram suas vidas em outros locais? A Rocinha, por exemplo, tem uma grande quantidade de migrantes do Nordeste. Essas pessoas herdaram o saber fazer nordestino das rendas e dos bordados e isso é uma herança cultural, sem dúvida, mas elas não estão mais no Nordeste. Parece complicado falar em identidade cultural com essas pessoas. Qual é a sua percepção sobre isso?

12. Em relação à comercialização dos produtos, quais os principais gargalos? Com que frequência são organizadas as feiras do Circuito Ecosol?

13. Existe uma preocupação em aumentar o valor agregado desses produtos?

14. Como você vê a questão recente da regulamentação da profissão do artesão? Traz vantagens para o profissional?

15. Gostaria que você concluísse a nossa entrevista, dando seu depoimento sobre a importância da pacificação para as comunidades em que vocês têm atuado. 
6) Entrevista com Ruth Jurberg, Coordenadora Social do PAC , Empresa de Obras Públicas do Estado do Rio de Janeiro.

1. Quais foram os objetivos do PAC SOCIAL na Rocinha?

2. Quanto foi investido, por meio do PAC, na Rocinha? Em 2015, devido à crise econômica os investimentos foram contingenciados? As ações do PAC na Rocinha, então, foram interrompidas?

3. Quais os principais projetos do PAC na Rocinha?

4. Vocês do PAC Social (coordenado pela Secretaria de Estado de Obras do Rio de Janeiro) trabalharam com a equipe do IPP Social, da Prefeitura?

5. Houve ações comuns entre os dois programas? E quais foram as críticas dessa parceria?

7) Entrevista Sebrae/ Rio: Renata Roqui de Morais e Suzana Mattos, da Coordenação de Desenvolvimento do Empreendedorismo em Comunidades Pacificadas .

1. Quando começou o Programa de Desenvolvimento do Empreendedorismo em Comunidades Pacificadas?

2. Quais as principais metas do programa?

3. O programa é desenvolvido em parceria com o governo? Existem outros parceiros?

4. Quais as principais fragilidades do programa?

8) Entrevista com Fabiane Albuquerque - Coordenadora de Projetos, Instituto Pereira Passos, Prefeitura do Rio de Janeiro.

1. Como vem sendo trabalhado pelo IPP o apoio ao empreendedorismo nas favelas pacificadas do Rio de Janeiro?

9) Entrevista com Dayse Valença - Administradora da ONG ASPLANDE ( Assessoria \& Planejamento para o Desenvolvimento )

1. Que tipo de apoio vocês vêm oferecendo ao desenvolvimento do empreendedorismo em favelas cariocas?

\section{Entrevistas nas favelas Santa Marta e Rocinha:}

\section{I) Favela Santa Marta}

Pessoas entrevistadas:

a) Artesãs do Grupo Costurando Ideais: Sonia e Marisete 
b) Artesã e dona de loja: Andréia

c) Profissionais que trabalham com turismo: Salete, Elias, Mário.

\section{II) Favela da Rocinha}

Pessoas entrevistadas:

a) Artesãs do Grupo Coopa-Roca: Maria Áurea, Lucélia e Luci.

b) Liderança comunitária: José Martins

c) Dono de uma loja de produtos artesanais: José Luiz

d) Pesquisadora e consumidora: Isabella Nunes.

Roteiro Básico das Entrevistas realizadas com as artesãs:

1. Como o grupo surgiu e como se deu a sua trajetória?

2. Quais os principais produtos que vocês fazem?

3. Qual a importância da atividade artesanal para o sustento das famílias?

4. Qual a maior dificuldade da atividade artesanal desenvolvida por vocês?

5. Como é feita a comercialização da produção?

6. Quais as potencialidades?

7. Em relação à pacificação, vocês acham que ajudou o trabalho de vocês?

Roteiro Básico das Entrevistas realizadas com as outras pessoas dessas comunidades:

1. Vc percebe alguma mudança no dia a dia da favela partir da instalação da UPP?

2. Em relação aos negócios, aos empreendedorismos, percebeu alguma mudança a partir da instalação da UPP?

Grupos de artesãs moradoras de favelas pacificadas que entrevistei:

1. Costurando Ideais - Favela Santa Marta: Sonia e Marisete;

2. Coopa-Roca _ Favela da Rocinha. Pessoas entrevistadas: Maria Áurea, Lucélia e Luci.

3. Mulheres Guerreiras: Favela da Babilônia. Pessoas entrevistadas Vera Rufino e Patríca.

4. Grupo Corte e Arte : Favela do Morro do Cantagalo. Pessoa entrevistada: Elisete.

5. Grupo Devas: Favela Nova Holanda, do Complexo da Maré. Pessoa entrevistada: Clarice

6. Rede Repsol: Favela do Alemão. Pessoa entrevistada: Mara

7. Cidade de Deus : pessoa entrevistada: Sueli

8. Artesã Waldinéia Bastos de Souza Martins : Comunidade do Morro do Andaraí 
9. Grupo Arteiras - Favela da Casa Branca. Pessoa entrevistada: Rosana

10. Mulheres Revolucionárias - Favela da Rocinha. Pessoa entrevistada: Edileusa

11. Galpão das Artes da Dona Augustinha - Favela Chapéu Mangueira 


\section{AUTORIZACCÃO E TERMO DE CESSÃO DE DEPOIMENTO}

Pelo presente instrumento, autorizo a pesquisadora de doutorado do CDS-UnB, Andréa Mello Gouthier de Vilhena, inscrita no RG 05485278-5, a utilizar meu depoimento em entrevista concedida para a sua tese de doutorado.
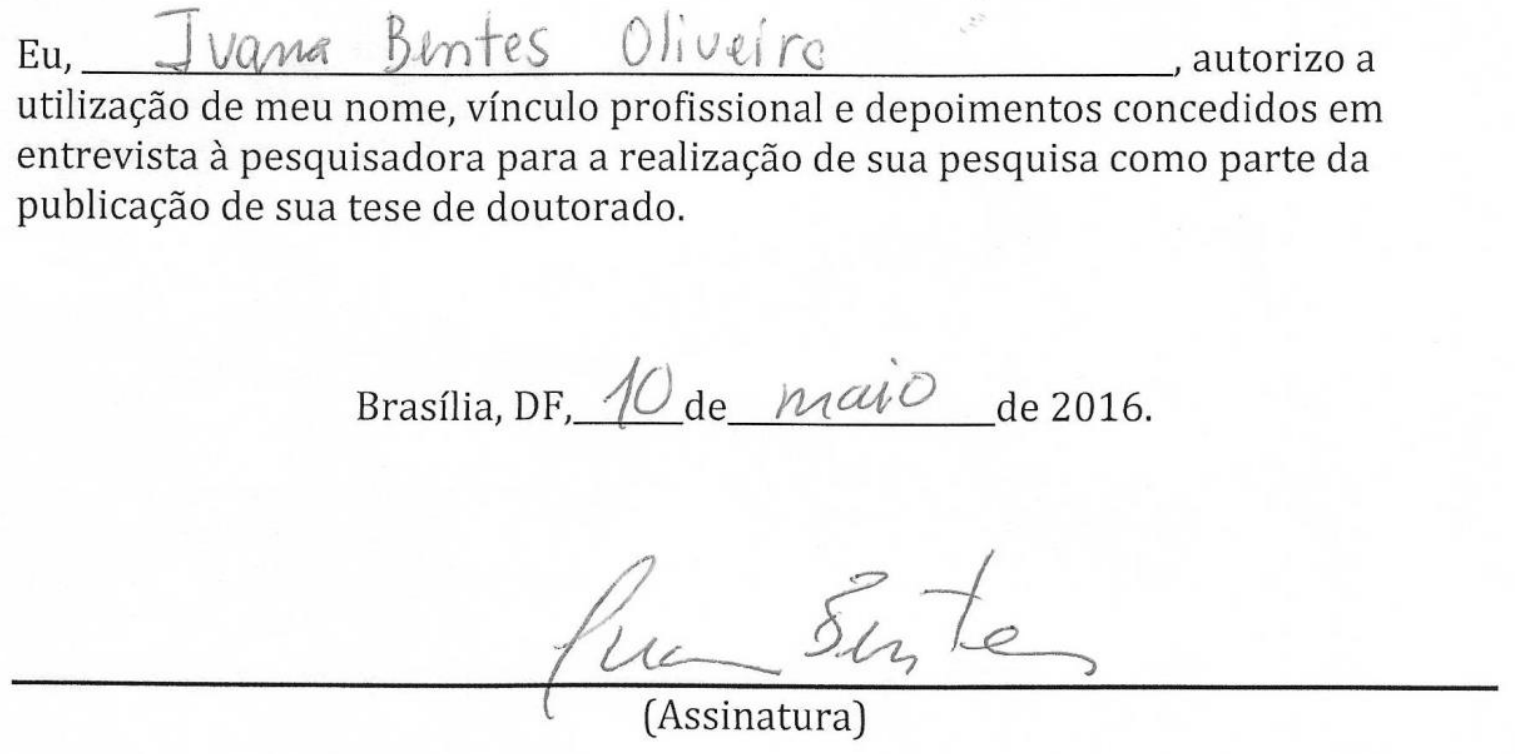

Nome: IVAWA BEWTES OLIUEINW

CPF: $759274117-20$

$R G: \frac{119685 \rho S P-N C}{S P}$ 


\section{AUTORIZAC̣ÃO E TERMO DE CESSÃO DE DEPOIMENTO}

Pelo presente instrumento, autorizo a pesquisadora de doutorado do CDS-UnB, Andréa Mello Gouthier de Vilhena, inscrita no RG 05485278-5, a utilizar meu depoimento em entrevista concedida para a sua tese de doutorado.

eu, Rejane Nobre 6 a autorizo a utilização de meu nome, vínculo profissional e depoimentos concedidos em entrevista à pesquisadora para a realização de sua pesquisa como parte da publicação de sua tese de doutorado.

Brasília, DF, 11 de_mavo de 2016.

$\frac{\operatorname{lej} \cos \operatorname{NoS}_{0} \cos -}{\text { (Assinatura) }}$

Nome: ReJane NÓbrega

CPF: $318.568 .704-30$

$R G: 24.027 .377 .1$ 
Eu, Ana Asti, auhrizo a publicaeaco do meu depoimento para firns ara dimicos mais ispecificamente pava a publica cai da tese de doutorado llempreende dorismo hianve sustentebilide de em Favilas Pacificadas no Ris de fanciro de Andréa Mello Gouthier de Vilhena.

Nio de Janciro, 2016

206 
Eu, Josi Elias Peneiro Duarte, auturizo a publicacad do meu depuimento fol fins accdémicos, mais uspecificamente para a puhlicacas da tese de douta do "Empreende dorismo Criativo e Sustentobilidade em Favilas Paeflectas, no RJ":

CPF $000518637-40$

Rio de andiro, 2016/2015

207 
Eu, ISABELLA NUNES PEREIRA, auhnizo a puhlicecas do meu depoiment p/ fins acodiomias mais esferificementa pare e publicacas de tese de dedubrado. "Em préndedoris no hiatioo e Sustantobilide de em favelas pacificadas no RJ".

Habl Ner

cpt: $351180757-34$

Rio de Januiro, $2016 / 2015$

208 
Eu, Josi Martins de Oliveire, autodizo a publicacas do meu depoimento e minha Imagem para fins academicos, mais especificameñt para c puhlicacas da tere de douturado "Empremdedorismo quatio e suspente bilide de em favelas pacifícadas no hio de faneiro. de Andrec mello Gouthier de Vithena.

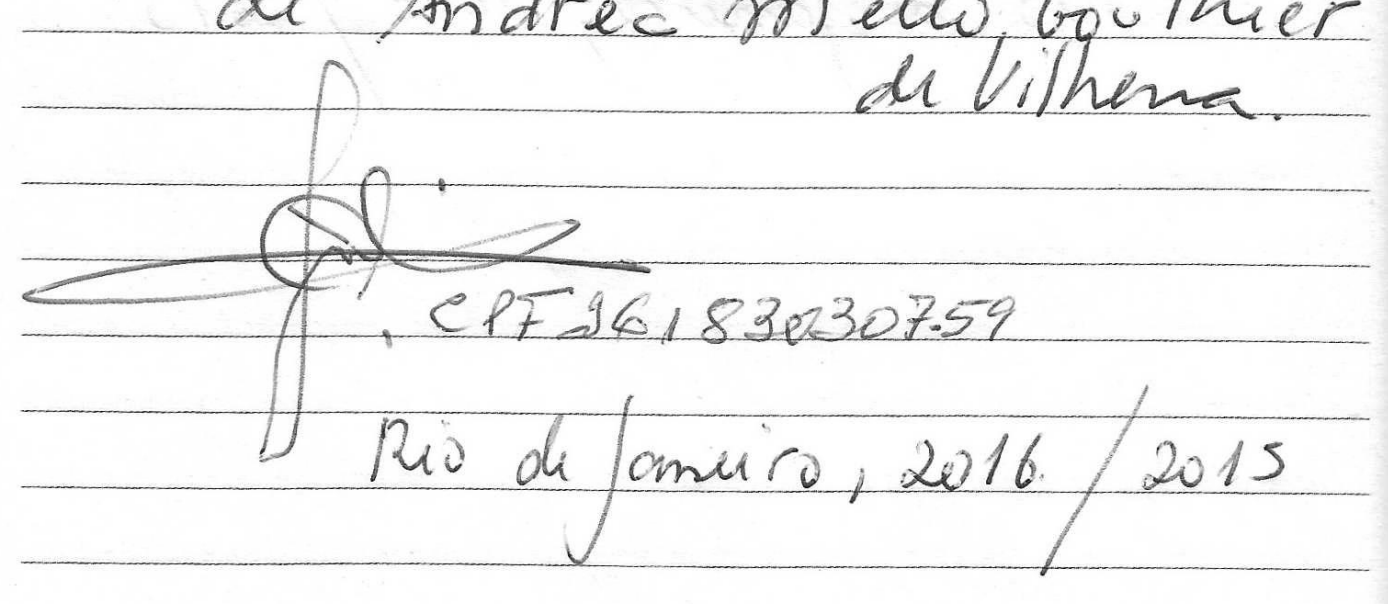

209 
Eu, Manic Aurec Feiloso Paz, aubrizo a publicacas do mé depoiment e mimha Imagem arrim wmo do ambient de trebctho e produtos da cooperative Coupa-Roca powa fins acadimicos, mais especificament para a publice car da tele de dou borado "Émmeende dorismo Cviatioo e Sustenthbilidede em lavelas pacificadas no Rio de janciro.

de Andre: Mello bouthier de vilhere

- Maria Aurea Fitosa Paz

Mio de Jamiro, 2016/2015

210 
Eu, Maric do socurro Cas valho dus santos (Lurcilic), autorizo a puhticacar do meu dipoimento e minté Imagem assim como do ambiente drebctho e pulutus da cooperative Coopa- Roce pare fins accdimius, mais ispecificomento para a publicaeas de tex de doub rado de Andric Millo bouthier of lithene.

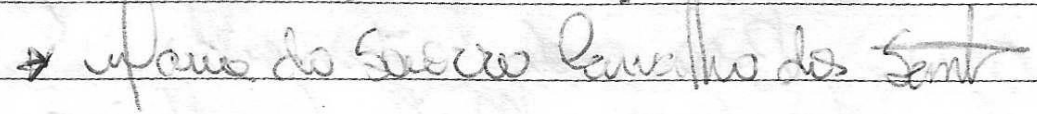

Rio di Jameiro, $2016 / 2015$

211 
Ev, fose buiz de lon cuicas sille, autort zo a publicacas do man depoimento le minhá Ima gem arsir como da loga para fins acadimicos, mais especifica mente para a publicacas da fere de doutorado "Empreendedoris no Criativo e Sustantabitide.

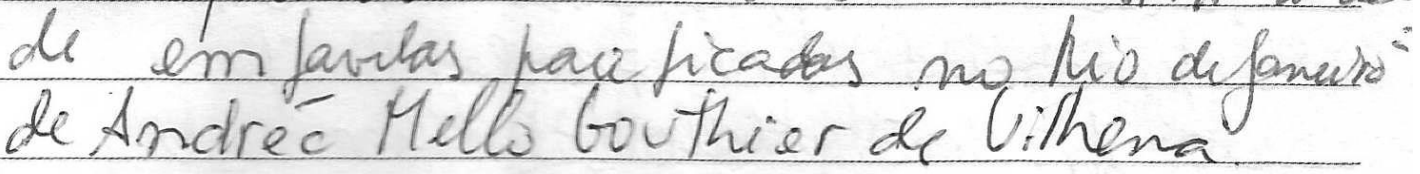

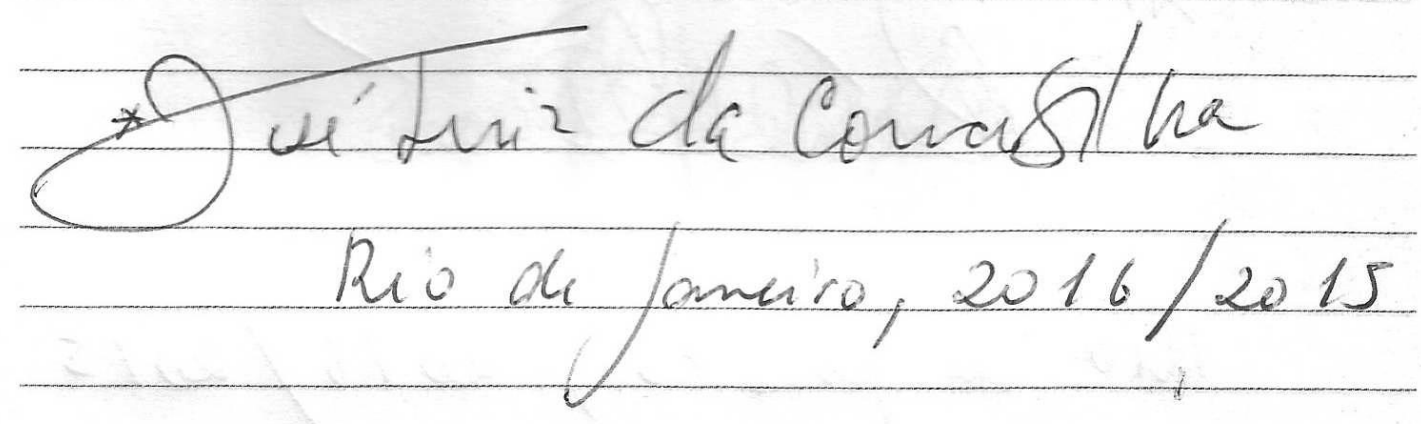

212 
Ev, Salete Martins, auto rizo a jublicacas do men depoimenb e minke Imagens pare fins acadimicus, mais especificomate pare a fuiblicecaio da tese de ducturado 11 Empreendedorismo Giativo e bustentebilided eM Favelas Pacificadens woRY de Andréo Hello Gouthier de Vilhene.

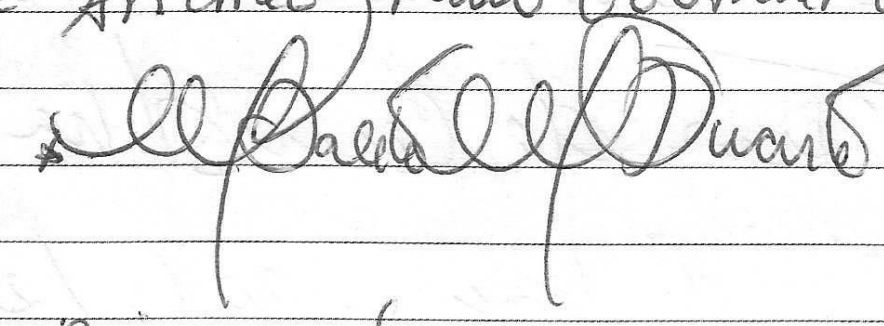

Rio de Janairo, $2016 / 2015$

213 
Eu, Mario Sergio Martins, aulwrizo a publicccas do meu de poiment e mimb imcens pare fins acedimicos, mais especificamente para e publicacar de tese de douturado "Empreende dorismu liatiou e Sustentabilide de em Faulas Paw ficadas no RI: de Indréc Mello Gouthier de Wilhene.

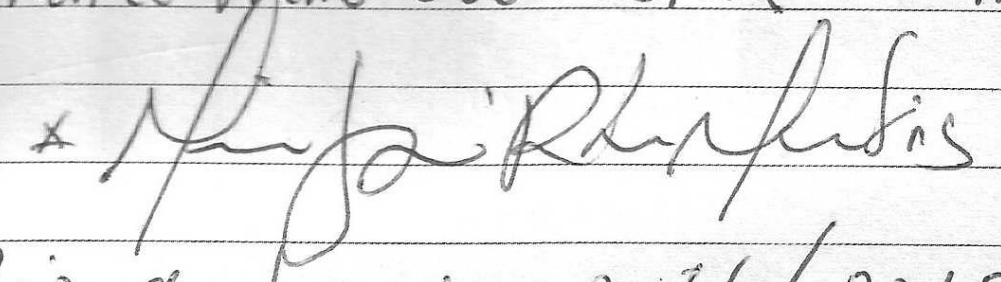

Rio de anuiro, $2016 / 2015$

214 
